Neutron Dosimetry at Commercial Nuclear Plants

Annual Report of Subtask D: TEPC Feasibility

F. M. Cummings

G. W. R. Endres

J. C. McDonald

L. W. Brackenbush

June 1984

Prepared for the U.S. Nuclear Regulatory Commission under Contract DE-AC06-76RLO 1830

NRC FIN B2282

Pacific Northwest Laboratory Operated for the U.S. Department of Energy by Battelle Memorial Institute 


\title{
DISCLAIMER
}

This report was prepared as an account of work sponsored by an agency of the United States Government. Neither the United States Government nor any agency thereof, nor any of their employees, makes any warranty, express or implied, or assumes any legal liability or responsibility for the accuracy, completeness, or usefulness of any information, apparatus, product, or process disclosed, or represents that its use would not infringe privately owned rights. Reference herein to any specific commercial product, process, or service by trade name, trademark, manufacturer, or otherwise, does not necessarily constitute or imply its endorsement, recommendation, or favoring by the United States Government or any agency thereof. The views and opinions of authors expressed herein do not necessarily state or reflect those of the United States Government or any agency thereof.

\author{
PACIFIC NORTHWEST LABORATORY \\ operated by \\ BATTELLE \\ for the \\ UNITED STATES DEPARTMENT OF ENERGY \\ under Contract DE-AC06-76RLO 1830
}




\section{NEUTRON DOSIMETRY AT COMMERCIAL NUCLEAR PLANTS \\ ANNUAL REPORT OF SUBTASK D: TEPC FEASIBILITY}

F. M. Curmings

G. W. R. Endres

J. C. McDonald

L. W. Brackenbush

June 1984

Prepared for the U.S. Nuclear Regulatory Commission under Contract DE-ACO6-76RLO 183D NRC FIN B2282

Pacific Northwest Laboratory Richland, Washington 99352 


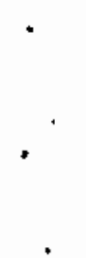


ABSTRACT

As part of a larger program to evaluate personnel neutron dosimetry at commercial nuclear power plants, this study was designed to observe the feasibitity of the use by NRC Ticensees of the tissue equivalent proportional counter (TEPC) system as a neutron monitoring instrument.

Laboratory tissue equivalent proportional counters were irradiated using ${ }^{252} \mathrm{Cf}$ sources at NBS and PNL and were irradiated inside containment of four operating nuclear power plants (two boiling water reactors and two pressurized water reactors). On the average, neutron dose-equivalent rates determined using the TEPC were 1.05 times the calculated dose-equivalent rates for the bare and moderated ${ }^{252} \mathrm{Cf}$ sources and 0.86 times the dose-equivalent rates determined using the multispheres inside containment of nuclear power plants. Further, neutron dose equivalent rates determined using portable remmeters were an average of 1.71 times the dose equivalent determined using the multispheres inside the containment of nuclear power plants. It was observed that while electronic noise from temperature and vibrational effects inside containment prohibited an adequate measure of absorbed dose from gammas, the measurement of neutron absorbed dose was unaffected by these environmenta] parameters. It is recommended that for use inside containment at nuclear power plants 1) the laboratory scale TEPC is the superior technique for accurate determination of neutron dose equivalent, 2) for rentaneters similar to the one evaluated in this study, neutron dose equivalent response should be corrected to account for dependence of response on neutron energy or the remmeters should calibrated using a moderated neutron source, and 3) at present, the TEPC should not be used to measure absorbed dose from gammas. Upon the advent of a proven miniaturized TEPC, this instrument may prove to be a desirable replacement for current portable neutron monitoring devices for the determination of dose equivalent inside containment of commercial nuclear power plants. 

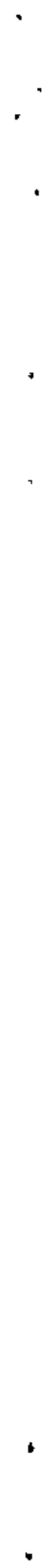


\section{SLMMARY}

This study is part of a larger program to evaluate personnel neutron dosimetry at commercial nuclear power plants. Results of previous tasks in the program indicate that portable remmeters used inside containment of nuclear power plants to determine neutron dose equivalent rates respond high compared to reference values. This high response demonstrates a significant dependence of the instrument response on the energy of incident neutrons.

A laboratory tissue equivalent proportional counter system (TEPC) was used to measure absorbed neutron doses and determine neutron dose equivalents by using quality factors inferred from the absorbed dose distribution for neutron fieids encountered inside containment of operating nuclear power plants. The TEPC was also used to measure absorbed neutron dose and determine neutron dose equivalents in well characterized neutron fieids produced by bare and moderated ${ }^{252} \mathrm{Cf}$ sources at the Nationai Bureau of Standards and at the Pacific Northwest Laboratory to provide a basis for evaluating this technique.

The TEPC system consists of the TEPC detector, a preamplifier, a high voltage power supply, signal and high voltage cables, a spectroscopy amplifier, an analog to digital converter ( $A D C$ ), a multichannel analyzer, tape cassette for data storage, and a computer to analyze data. The electronics fisted above are the same electronics used to support the multisphere measurements which were used as reference vaiues throughout this study in order to provide continuity with the other tasks in the program. The two systems measure different quantities though; the TEPC measures absorbed dose in a simulated volume of tissue in air from charged secondary particies, while the multisphere system measures the number of thermal neutrons ( $1 / v$ detector) at the center of the polyethylene spheres. The TEPC measures absorbed dose directly while the multisphere technique infers kerma to element 57 by mathematically constructing the neutron flux spectrum and applying fiux-to-kerma conversions. The dose equivalent is determined using the TEPC by mutliplying the absorbed dose by a quality factor based on the distribution of dose events. The multisphere data is used to determine dose equivalent by using flux to dose equivalent conversion factors. The quality factors determined by the two techniques will be inherentiy different because the quality factor 
determined using the TEPC is based on the linear energy transfer of secondary charged particles while the quality factor determined using the muitisphere technique is the mathematical maximum value in a 15-in. sphere for neutrons in particular energy groups.

The inherent differences between the TEPC and portable remeters 1 ie chiefly in two areas. The first difference is the dependence of the particular measurement technique on the energy of incident neutrons. Portable remmeters have demonstrated energy dependence (Schwartz et al. 1983; Hankins 1977; Cosack and Lesiecki 1981) such that the response of the remeter must be related to dose equivalent rate through appropriate calibration or correction techniques. The TEPC directly measures absorbed dose to an equivaient volume of tissue in air and determines a qualjty factor pertinent to each neutron radiation field from the LET distribution and as such needs no external calibration.

Pertaining to the portability of the two techniques, currently, the remmeter is much more portable (20-25 pounds) than the TEPC and associated electronics (approximately 80 pounds). Additionally, the laboratory TEPC does not provide a read out at the time of measurement.

This study demonstrates that the TEPC technique is conceptually superior to the portable remmeter for determining dose equivalent. A miniaturized seif-contained TEPC instrument will be evaluated later to prove over all superiority.

The TEPC measurement technique in this task differs from the technique used in Subtask B to evaluate the responses of personnel neutron dosimeters. The difference lies in the selection of TEPC systems using low-noise preamplifiers and a system of two amplifiers per measurement. Using two amplifiers per measurement permitted analysis of events over the range of roughiy $0.3 \mathrm{keV} /$ micrometer to $1000 \mathrm{keV} /$ micrometer. Routine TEPC measurements employing a single amplifier do not have the dynamic range to accommodate this depth of analysis. The U.S. Department of Energy has under taken the development of a portable TEPC-based instrument which will detemine neutron- and gamm-dose equivalent/rates in mixed radiation fields. 
Because the TEPC measures neutron absorbed dose directly, is more straightforward in analysis than the muitisphere technique and because the energy dependence of remmeters leads to an over estimation of neutron doseequivalent rates in containment by a factor of 1.71 on the average, the authors concluded that 1 ) the TEPC is the superior technique for accurate determination of neutron dose-equivalent/rate inside containment of nuclear power plants; 2) that results from renmeters currently in use and similar to the one evaluated herein be adjusted to account for energy dependence or that the remmeters be calibrated using a moderated neutron source which provides response similar to the response to neutrons found inside containment of conmercial nuclear power plants, and 3 ) that the TEPC not be used to measure absorbed dose from photons at this time. Further, when a miniaturized portable version of the TEPC is available, it should be evaiuated as to its application to dose equivalent determination inside containment of commercial nuclear power plants thereby verifying the appropriateness or inappropriateness of the technique for routine neutron dose equivalent monitoring. 


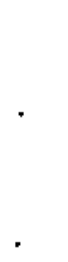




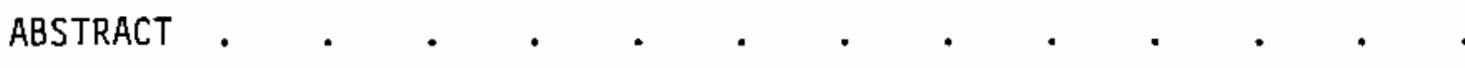

SUMMARY

INTRODUCTION

INSTRUMENT DESCRIPTIONS

TISSUE EQUIVALENCE

SIGNAL PRODUCTION

Gas Gain

Pulse Production and Dose

Pulse Size and Lineal Energy

QUALITY FACTOR AND DOSE EQUIVALENT .

DATA ANALYSIS

RESULTS

NBS - ${ }^{252}$ Cf IRRADIATIONS.

PNL $-{ }^{252} \mathrm{CF}$ IRRADIATIONS .

REACTOR IRRADIATIONS

Reactor 1 . . . . . . . . . . . . 25

Reactor 2 . . . . . . . . . . . . . 25

Reactor $3 . \quad$. $\quad . \quad$. . . . . . . . 26

Reactor 4 . . . . . . . . . . . . 26

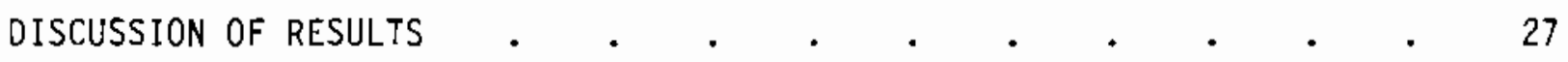

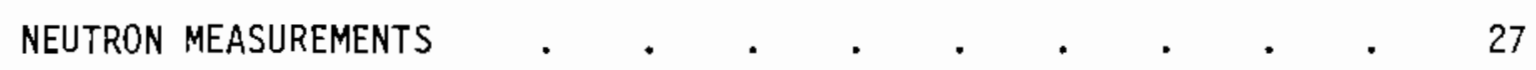

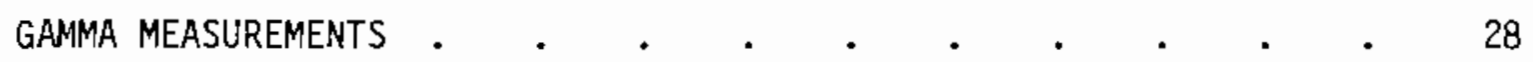

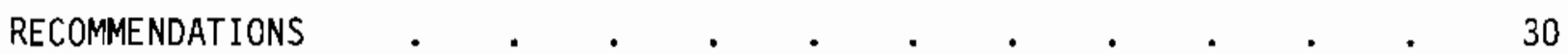

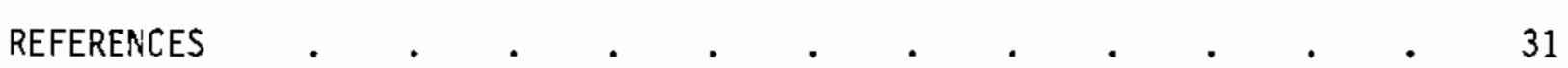

APPENDIX - SUMMARY NEUTRON MEASUREMENTS . . . . . . . . . A.1 


\section{FIGURES}

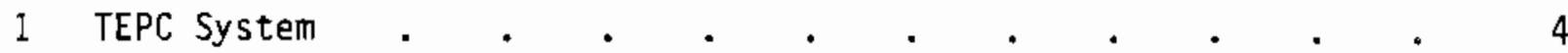

2 Tissue Equivalent Proportional Counter Construction . . . 5

3 Multisphere System . . . . . . . . . . . . . 6

4 Kerma/Fluence for Hydrogen, Carbon, Nitrogen, Oxygen, and Wet Tissue . . . . . . . . . . . 8

5 First Collision Dose Versus Photon Energy $\quad$ * $\quad . \quad$. $\quad . \quad$. 9

6 TEPC Analysis Flow Chart . . . . . . . . . . . . . 19

7 Raw Data Spectrum From a Reactor Measurement Using the TEPC. . . . . . . . . . . 20

8 Neutron and Gamma Dose Measured by the Tissue

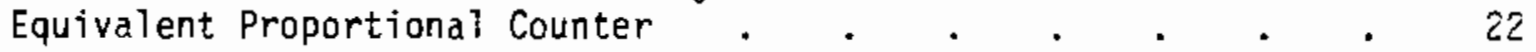

9 The Distribution $y^{2} N(Y)$ as a Function of $Y$ for a

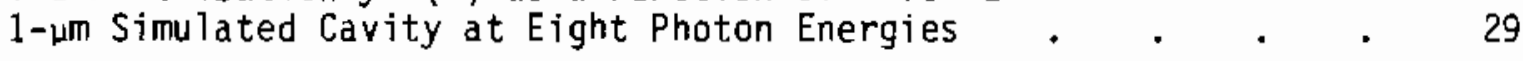

$10 \mathrm{y}^{2} \mathrm{~N}(\mathrm{y})$ Distribution from a $\mathrm{D}_{2} \mathrm{O}$-moderated ${ }^{252} \mathrm{Cf}$ Source . . . . 29 


\section{TABLES}

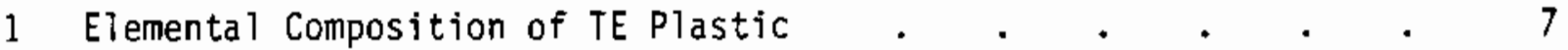

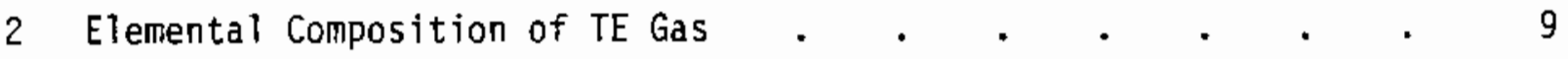

3 Characteristics of Counting Gases . . . . . . . . . . . 11

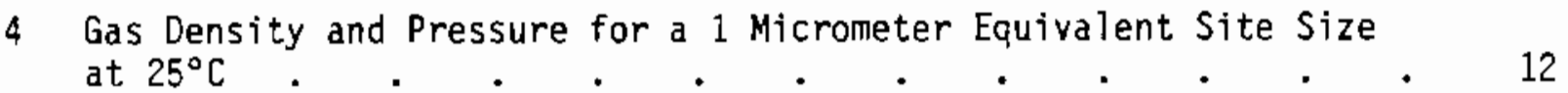

5 LET-QF Relationship . . . . . . . . . . . . . . . . . 14

6 Neutron Dose Measurements on Bare and Moderated ${ }^{252} \mathrm{Cf}$ at NBS . 23

7 Neutron Dose Measurements on Moderated ${ }^{252}$ Cf at PNL . . . . 24

8 Neutron Dose Measurements for Reactor 1 (BWR) . . . . . 25

9 Neutron Dose Measurements for Reactor 2 (BWR) . . . . . 25

1D Neutron Dose Measurements for Reactor 3 (PWR) . . . . . 26

11 Dose Measurements for Reactor 4 (PWR) . . . . . . . . . 26

Average Ratio of TEPC Dose Equivalent to Reference
Dose Equivalent $\quad$..$\quad$. . . . . . . . . 27 


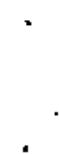




\section{INTRODUCTION}

This study is part of a six year project, funded by the U.S. Nuclear Regulatory Commission (NRC), to evaluate personnel neutron dosimetry at commercial nuclear power plants. In the first two phases of the project, neutron spectrum, flux, and dose measurements indicated that 1) the average energy of neutrons producing the significant amounts of dose inside containment of pressurized water reactors was on the order of $50 \mathrm{keV}$ and 2) the only cormercially available dosimeter appropriate for use in those fjelds was the TLD-albedo which incorporated ${ }^{6} \mathrm{Li}$. The predominance of neutrons with energies less than $100 \mathrm{keV}$ caused the dosimeters to indicate that more dose equivalent was received than actually was received. The reasons for that 'high response' lie in the energy dependence of the response of the TLD and in the choice of calibration sources (Endres et a1. 1981; Cummings et al. 1983).

While noting the energy dependence of the TLD, a similar dependence (though not as severe) was noted in the portable neutron monitoring instruments, called remmeters. Depending on the type of remmeter chosen, these instruments responded 1.5 to 8 times higher than the reference measurements (muitispheres and tissue equivalent proportional counters [TEPC]). Because the TEPC measures absorbed dose directly and is self-calibrating, it was evaluated for its application to neutron dose measurements inside containment of commercial nuclear power plants and also for its application in photon dose measurements. The question to be answered was: could the TEPC be used to accurately measure absorbed dose from neutrons and gammas and then be used to determine dose equivalent using quality factors inferred from the distribution of dose events? In addition, the TEPC technique needed evaluation to demonstrate the feasibility that a TEPC-based system could adequately serve as a routine neutron monitoring instrument.

To answer the questions, a laboratory TEPC was irradiated using bare and moderated ${ }^{252} \mathrm{Cf}$ sources at the National Bureau of Standards (NBS) and at the calibration facitity at Pacific Northwest Laboratory (PNL) and measurements were performed inside containment of operating commercial nuclear power plants. While the TEPC accurately measured absorbed dose from neutrons and accurately determined neutron dose equivalent, the smalier events due to 
photon interactions were masked by the electronic noise of the laboratory system. The average dose equivatent response of the TEPC compared to calculated neutron dose equivalents for the ${ }^{252} \mathrm{Cf}$ irradiations was $1.05 \pm 0.14$. The calculated neutron dose equivalents are enumerated by McDonald et al. (1983) and by Stoddard and Hootman (1971). The average dose equivalent response of the TEPC compared to dose equivalents determined from muTtisphere measurements inside containment was $0.86 \pm 0.20$. The multisphere system has been the reference measurement technique throughout this study and previous tasks in this program. The average dose equivalent response of remmeter compared to multisphere measurements inside containment was $1.71 \pm 0.74$. The average dose equivalent response of the remmeter compared to the dose equivalent determined using the TEPC was $1.99 \pm 0.78$.

The photon measurements performed inside containment with the TEPC did not yieid useful results because of increased noise from the linear amplifiers and external power supplies needed for supporting the TEPC measurements. . Those problems could be resolved by incorporating an internal power supply (long-life battery). Indeed, a 2-1/4-in. TEPC incorporating a low-noise preamp and internal high-voltage power supply was used to determine the neutron dose equivalent in the field produced by a $\mathrm{O}_{2} 0$-moderated ${ }^{252} \mathrm{Cf}$ source at PNL. Even though the conditions were tightly controlled, enough electronic noise was introduced by the long signal cables and linear amplifiers to only allow analysis to the $0.5 \mathrm{keV} /$ micrometer range. In conclusion, the present TEPC systems are incapable of resolving the very low-energy recoil electrons produced by photons from those produced by electronic noise.

This project will continue into $\mathrm{FY}-1984$ in order to evajuate a portable version of the TEPC with a built-in microprocessor for determination of neutron absorbed dose and dose equivalent (and the associated rates) at the time of measurement. The feasibility of using this portable TEPC for routine monitoring at licensee facilities will be investigated. 


\section{INSTRUMENT DESCRIPTIONS}

The TEPC system used in this task (Figure 1) consists of the TEPC detector, a preamplifier, a high voltage power supply, signal and high voltage cables, a spectroscopy amplifier, an analog to digital converter ( $A D C$ ), a multichannel analyzer (MCA), tape cassette read out, and a personal computer to analyze data. The TEPC detector is a hollow sphere with walls that are $0.123 \mathrm{in}$. thick and constructed from Shonka A-150 plastic. A single wire anode has been stretched between the two poles of the sphere. The detector is filled with propane-based filling gas before each set of measurements. Interactions between neutrons and the atoms in the plastic detector wall give rise to recoiling ions which traverse the cavity (see Figure 2). The energy deposited in the gas by the recoiling ion is equal to the product of the linear energy transfer and the length of the path traversed by the ion. Further description of the TEPC is presented in the following three sections: 1) the meaning of "tissue equivalence," 2) the production of signal, and 3) the determination of quality factor and dose equivalent.

The multisphere system (Figure 3 ) consists of a ${ }^{6} \mathrm{LiI}(\mathrm{Eu})$ detector, preamplifier, high voltage power supply, signal and high voltage cables, a spectroscopy amplifier, an ADC, MCA, tape cassette read out, and a main frame computer to analyze data. A measurement consists of determining the net count

rate due to the ${ }^{6} \mathrm{Li}(n, \alpha)^{3} \mathrm{H}$ reaction from the bare detector, from the detector covered with a cadmium shield and from the detector at the center of each of five polyethylene spheres of the following diameters: $3,5,8,10$, and 12 inches. The net count rates are used in an iterative unfolding code to solve the Fredholm integral for neutron energy spectrum and flux (Endres et a1. 1981).

The various aspects of the TEPC technique are further described below and the reader is directed to Endres et a1. (1981) for a discussion of the muitisphere technique.

\section{TISSUE EQUIVALENCE}

The tissue equivalent proportional counter (TEPC) is the only instrument currently available which can be used to measure absorbed dose from neutrons 


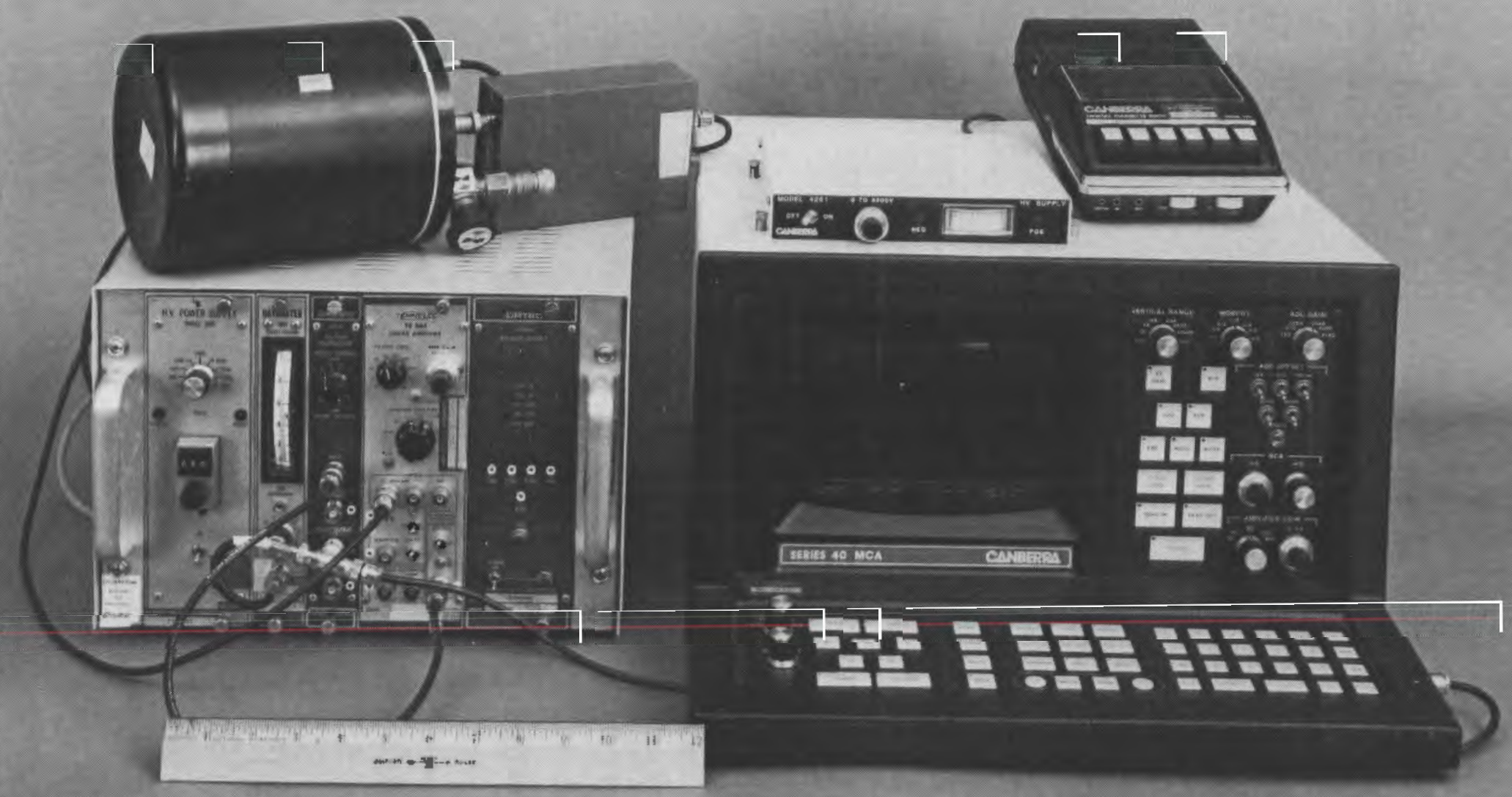

FIGURE 1. TEPC System 


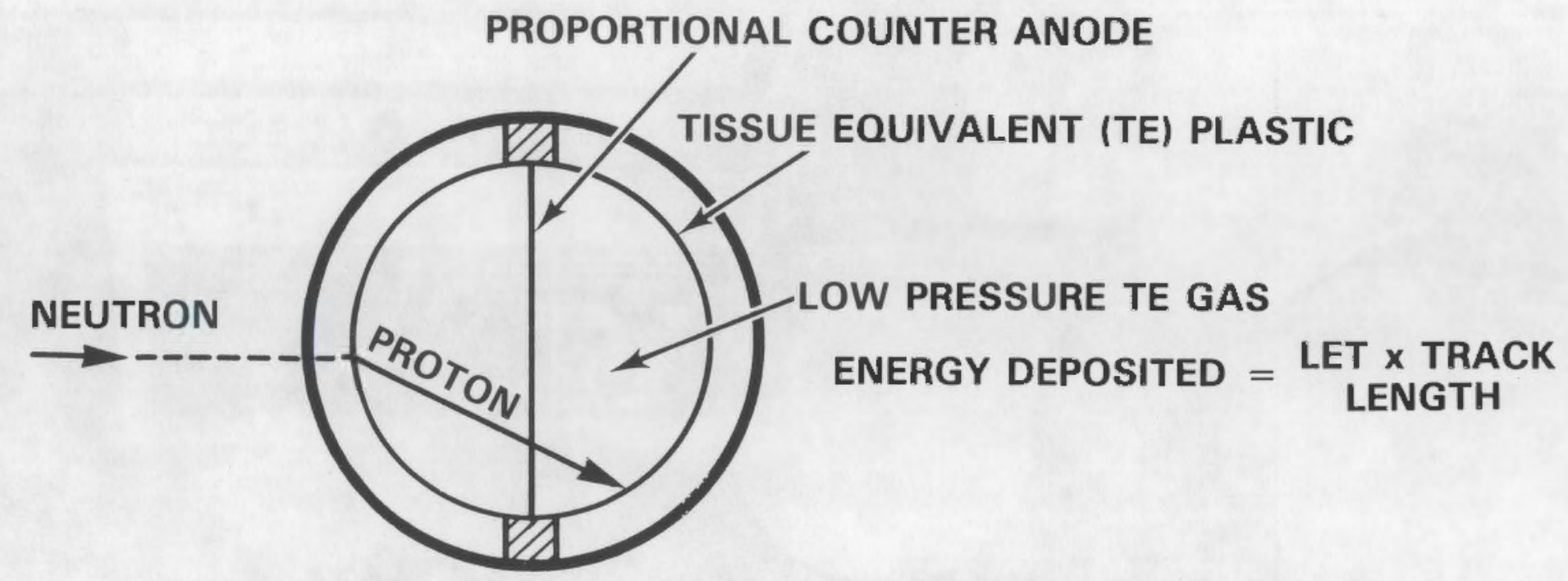

FIGURE 2. Tissue Equivalent Proportional Counter Construction 


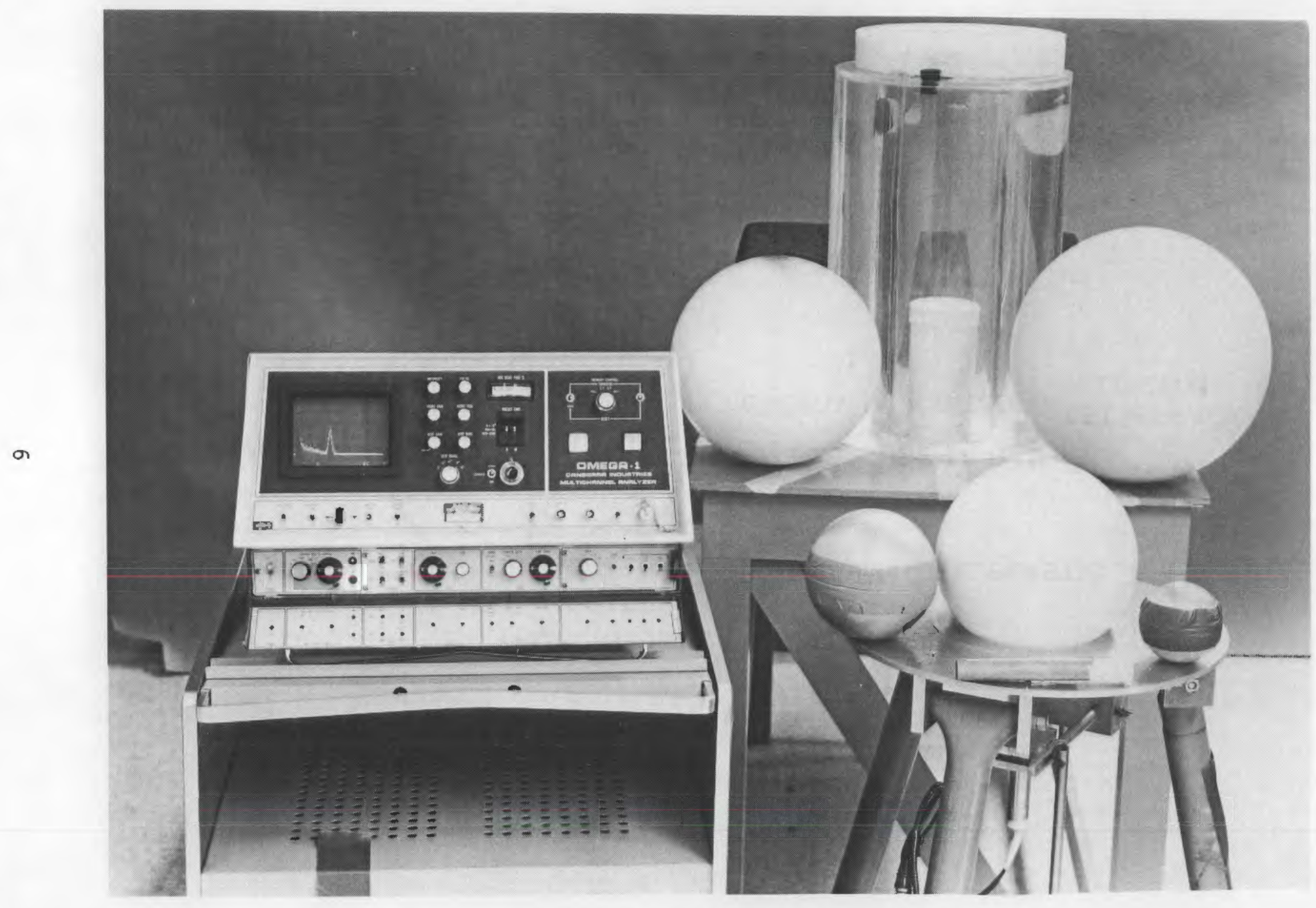

FIGURE 3. Multisphere System 
and infer a quality factor based on the way the dose is deposited in the counter (absorbed dose distribution).

The tissue equivalence (TE) of the counter is an important consideration in that the measurement is used to infer how energy is deposited in tissue from neutron induced events. The concept of tissue equivalence for the counter means that one expects neutrons (the radiation of interest in this case) to interact in the counter much the same way that the neutrons interact in tissue. For this condition to be true, the interaction cross sections of atoms comprising tissue and the plastic used in the counter have to be considered.

The 0.123-in. thick plastic wall of detector, Figure 2, is made of Shonka A-150 plastic. The composition of the plastic is enumerated in ICRU Report 26 (ICRU 1977) and is summarized in Table 1.

The tissue equivalence is apparent in the percent composition regarding hydrogen and nitrogen relative to ICRU muscle tissue. The importance of the equality of hydrogen and nitrogen and the relative unimportance of amounts of carbon and oxygen lies in the amount of dose deposited in tissue from neutron interactions with those various elements. The energy transfer from neutrons

TABLE 1. Elemental Composition of TE PJastic (ICRU 1977)

Percent Weight

\begin{tabular}{|c|c|c|c|}
\hline \multirow[b]{2}{*}{ Element } & \multicolumn{3}{|c|}{ Percent Weight } \\
\hline & $\begin{array}{l}\text { ICRU Muscle } \\
\text { Tissue } \\
\end{array}$ & $\begin{array}{l}\text { A-150 Design } \\
\text { Composition }\end{array}$ & $\begin{array}{l}\text { A-150 Chemical (a) } \\
\text { Analys is (std. dev. }{ }^{(\text {) }}\end{array}$ \\
\hline Hydrogen & 10.2 & 10.1 & $10.3(0.1)$ \\
\hline Ni trogen & 3.5 & 3.5 & $3.5(0.07)$ \\
\hline Oxygen & 72.9 & 5.2 & $6.4(0.6)$ \\
\hline Carbon & 12.3 & 77.6 & $77.1(0.3)$ \\
\hline Calcium & 0.007 & 1.8 & $\mathrm{NA}^{(\mathrm{c})}$ \\
\hline Fluorine & - & 1.7 & $\mathrm{NA}^{(\mathrm{C})}$ \\
\hline Total & $98.8^{(b)}$ & 99.9 & 97.3 \\
\hline
\end{tabular}

(a) Standard deviation of 5 replicate samples analyzed.

(b) The 1.1 percent remainder consists of $\mathrm{Na}, \mathrm{Mg}, \mathrm{P}, \mathrm{S}$, and $\mathrm{K}$. (c) NA: no analysis. 
to tissue is illustrated in Figure 4 (ICRU 1969). For neutrons with energy below $10 \mathrm{MeV}$, the predominant modes of energy transfer involve mainly nitrogen and/or hydrogen. Further, if one consults tabulated values of first collision dose to standard tissue, TE plastic and TE gas for neutrons with energies between 0.01 and $10 \mathrm{MeV}$, the maximum difference in total kerma is $5 \%$ (NBS 1961). It is for these reasons that the TEPC exhibits tissue equivalence.

Table 2 contains the composition of ICRU tissue and TE gas and forms the basis for the same arguments as for the plastic.

Tissue equivalence for photon interactions is a valid concept only for photons with energies greater than $0.1 \mathrm{MeV}, \mathrm{Figure} 5$. It can be noted that below $0.1 \mathrm{MeV}$ the tissue equivalence is no longer valid. This is because the primary interaction of photons with energies Tess than $0.1 \mathrm{MeV}$ is the photoelectric interaction. Since the cross section for photon absorption increases with the fourth power of the atomic number of the absorbing medium and with the inverse cube of the energy of the photon (Evans 1968) and since the TE plastic contains no trace quantities of the heavier elements (Tables 1 and 2) then the first collision dose in the TE plastic does not simulate the first collision dose in tissue for photons below $0.1 \mathrm{MeV}$.

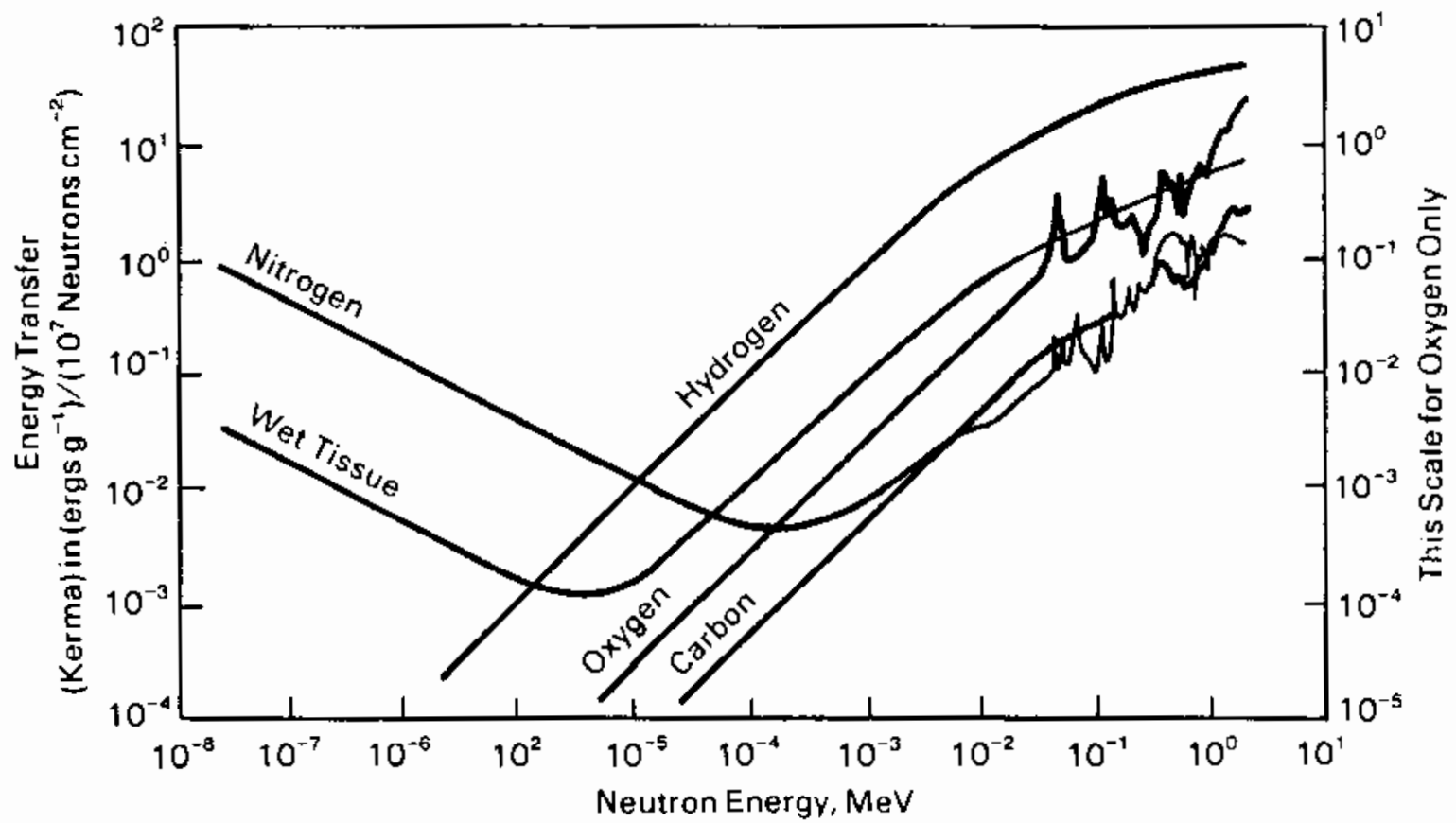

FIGURE 4. Kerma/Fluence (product of the mass energy transfer coefficient and the neutron energy) for Hydrogen, Carbon, Nitrogen, Oxygen, and Wet Tissue (ICRU 1969) 
TABLE 2. Elemental Composition of TE Gas (ICRU 1977)

\begin{tabular}{|c|c|c|c|}
\hline \multirow[b]{2}{*}{ Element } & \multicolumn{3}{|c|}{ Percent Weight } \\
\hline & $\begin{array}{l}\text { ICRU Muscte } \\
\text { Tissue } \\
\end{array}$ & $\begin{array}{c}\text { TE Gas (a) } \\
\text { Methane-Base }\end{array}$ & $\begin{array}{c}\text { TE Gas } \\
\text { Propane-Base } \\
\text { (b) }\end{array}$ \\
\hline Hydrogen & 10.0 & 10.2 & 10.3 \\
\hline Nitrogen & 3.5 & 3.5 & 3.5 \\
\hline Oxygen & 71.6 & 40.7 & 29.3 \\
\hline Carbon & 14.9 & 45.6 & 56.9 \\
\hline Total & 100.0 & 100.0 & 100.0 \\
\hline
\end{tabular}

(a) $64.4 \%$ methane, $32.4 \%$ carbon dioxide, $3.2 \%$ nitrogen (partial pressures); Rossi and Failla 1956.

(b) $55.0 \%$ propane, $39.6 \%$ carbon dioxide, $5.4 \%$ nitrogen (partial pressures); Srdoc 1970.

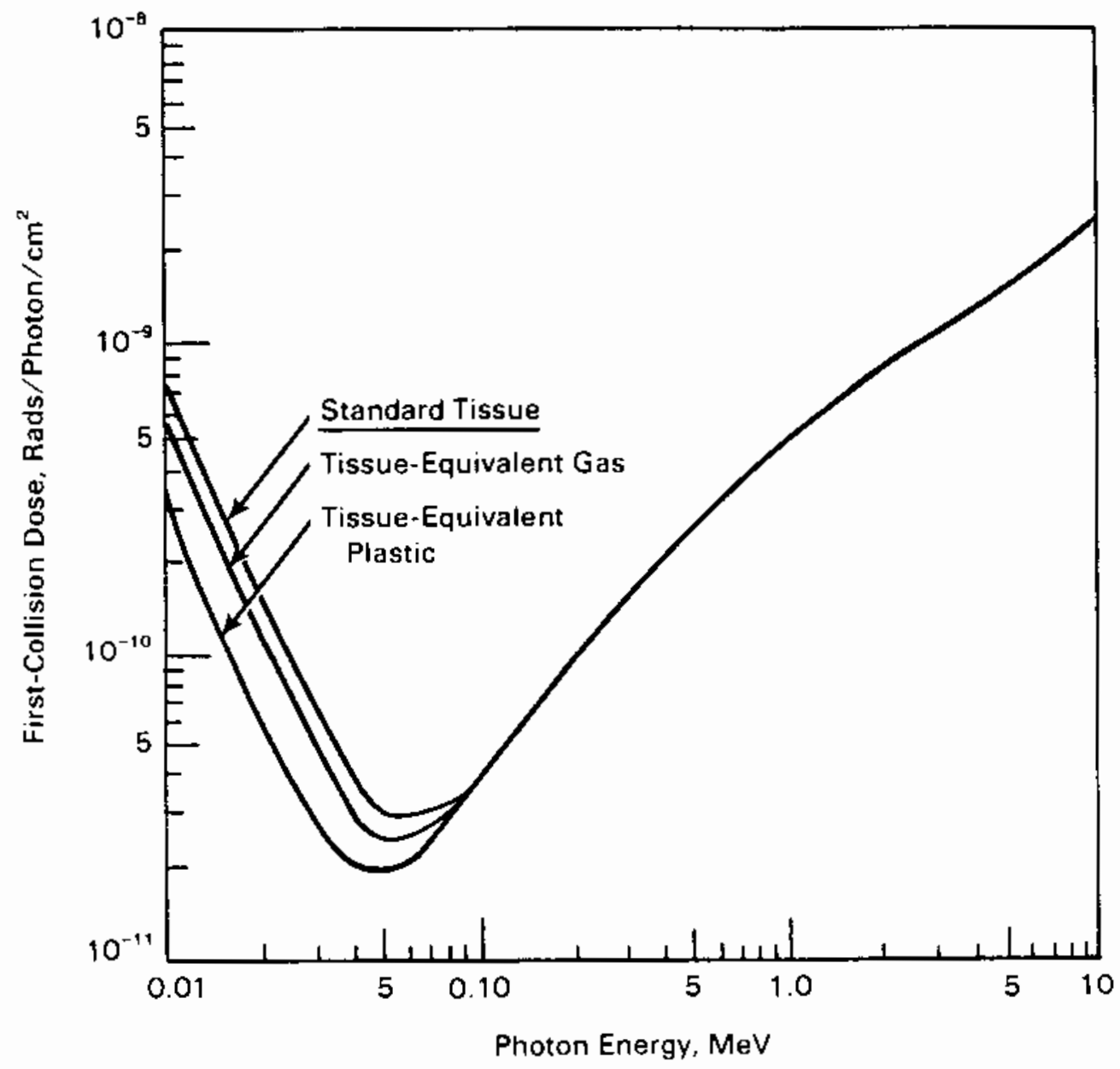

FIGURE 5. First Collision Oose Versus Photon Energy (NBS 1961) 
The application of the TEPC with respect to neutrons and photons must be considered from the perspective of the irradiations encountered and their effects upon dose deposition mechanisms. Inside containment of pressurized water reactors (PWR), the predominant numbers of neutrons are below $1.0 \mathrm{MeV}$ in energy (Endres 1981) and the predominant numbers of photons are emitted from ${ }^{60} \mathrm{Co}(1.17$ and $1.33 \mathrm{MeV})$ and ${ }^{137} \mathrm{Cs}(0.66 \mathrm{MeV})$. Hence the characteristic tissue equivalence for the TEPC hoids for both neutrons and photons generally. In boiling water reactors the added problem of ${ }^{16} \mathrm{~N}$ (emitting photons between 6 and $7 \mathrm{MeV}$ ) is encountered. In this region the pair production cross section increases roughily as the square of the atomic number (Evans 1955) so the tissue equivalence may not hold for the photon contribution. The tissue equivalence may not hold in those plants in which there are large numbers of low-energy photons $(<0.1 \mathrm{MeV})$ due to the presence of noble gas and iodine.

Overall the TEPC will provide a close measure of the absorbed dose to tissue if events between $0.1 \mathrm{keV} /$ micrometer and up are used for analysis.

SIGNAL PRODUCTION

Gas Gain

Ionization is the only mode of energy transfer from radiation to matter that will be considered in this discussion. The way that neutrons and gamma rays transfer energy to the TEPC is by interacting with the counter waIl and producing secondary charged particles which traverse the gas cavity.

In optimizing a proportional counter, it is desirable to get the maximum gain, or gas amplification, in order to finely discriminate voltage pulses, produced by the passage of the secondary particles. The gain may be manipulated by choosing the appropriate filling gas or by electronic amplification of the signals, or both. In considering the type of $T E$ counting gas to be used, two types are available which produce the best results: methane $\left(\mathrm{CH}_{4}\right)$ based TE gas and propane $\left(\mathrm{C}_{3} \mathrm{H}_{8}\right)$ based TE gas. The relationship of gain to gas characteristics is given by:

$$
\ln M=\frac{A}{\Delta V}\left[\ln \frac{B}{K p}\right] \quad \text { (from Knoll 1979) }
$$


where $\quad M=$ gas multiplication, or gain

$$
\begin{aligned}
\Delta V= & \text { potential difference through which an electron moves between } \\
& \text { successive ionizing events } \\
\mathrm{P}= & \text { gas pressure } \\
\mathrm{K}= & \text { minimum value below which multiplication cannot occur } \\
\mathrm{A}= & \ln 2 \cdot V / \ln (\mathrm{b}+\mathrm{a})=\text { constant } \\
V= & \text { applied voltage across the counter } \\
\mathrm{a}= & \text { radius of anode } \\
\mathrm{b}= & \text { radius of counter } \\
\mathrm{B}= & V /[\mathrm{a} \cdot \ln (\mathrm{b}+\mathrm{a})] .
\end{aligned}
$$

The onty values in equation 1 which are characteristic of the particular counting gas will be the $\Delta V, k$, and $p$. Values for $\Delta V$ and $k$ are given in Table 3 for pure methane and propane as an illustration to show how they differ.

The pressure of the gases will be a function of the density as certain numbers of hydrogen atoms are necessary to arrive at an equivalent site size of tissue. Table 4 gives the densities of the gases and pressures used to achieve a 1 micrometer equivalent site size.

It can be seen then that the gain is a complex function of the gas and is affected by operating parameters such as pressure and applied voltage as well as gas characteristics such as $\Delta V$ and $K$. The above discussion was developed to show why differences exist between gases. In the laboratory situation, we merely irradiated a TE-methane filled counter using a bare ${ }^{252} \mathrm{Cf}$ source, refilled the counter with TE-propane gas and reirradiated. Reference pulses were noted to be such that the propane based gas exhibited a gain that was twice that of the methane based gas.

\section{TABLE 3. Characteristics of Counting Gases}

(Knol1 1979)

\begin{tabular}{ccc}
$\begin{array}{c}\text { Gas } \\
(100 \%)\end{array}$ & $\begin{array}{c}K \times 10^{-4} \\
(V / c m-a t m)\end{array}$ & $\frac{\Delta V}{(\mathrm{eV})}$ \\
\hline Methane & 6.9 & 36.5 \\
Propane & 10.0 & 29.5
\end{tabular}


IABLE 4. Gas Density and Pressure for a I Micrometer Equivalent Site Size at $25^{\circ} \mathrm{C}$

\begin{tabular}{|c|c|c|c|}
\hline \multirow[b]{2}{*}{ Gas } & \multirow[b]{2}{*}{$\begin{array}{l}\text { Density } \\
\left(\mathrm{g} / \mathrm{cm}^{3}\right)\end{array}$} & \multicolumn{2}{|c|}{ Pressure } \\
\hline & & $\begin{array}{l}2-1 / 4-\text { in. Counter } \\
\text { (torr) }\end{array}$ & $\begin{array}{c}\text { 5-in. Counter } \\
\text { (torr) } \\
\end{array}$ \\
\hline TE-methane & 0.001136 & 12.9 & 5.8 \\
\hline TE-propane & 0.00182 & 7.8 & 3.5 \\
\hline
\end{tabular}

Pulse Production and Dose

Having discussed which properties of the counting system amplify the putses, a discussion of how signals are produced and what they mean is in order. As the secondary particles (i.e., proton, heavy ion or electrons) traverse the gas cavity, they ionize gas atoms producing free electrons. These free electrons are accelerated toward the anode ionizing more atoms as they go producing an "avalanche" of electronics. The size of the avalanche is a function of the gas multiplication. As the electrons are collected at the anode, a voltage pulse is produced. The pulse is proportional to the amount of energy deposited in the gas by the passage of the secondary charged particle. If the system is calibrated then, the energy deposited in the gas can be determined for each of the events and since the mass of the gas is known, the dose can be determined. Simpty, the dose is the energy divided by the mass or

$$
D=\frac{k \Sigma E}{m}
$$

where $\quad k$ is a proportionality constant

$\Sigma E$ is the sum of deposited energy from a 11 the events

$m$ is the mass of the gas.

The absorbed dose from the passage of the charged particles and hence from the incident radiations is thus measured directly and is a close simulation of dose in tissue.

Pulse Size and Lineal Energy

As stated earlier, the size of the pulse is proportional to the energy deposited in the gas. In order to determine a quality factor and convert 
absorbed dose to dose equivalent, the 1 ineal energy spectrum must be determined (a discussion of LET, Tineal energy and quality factor follows in the next section). To do this, individual pulses are recorded, after amplification, in a multichannel analyzer for subsequent analysis. In order to convert pulses to event size for quality factor determination, several assumptions are made. For instance, one such assumption is that secondary particles do not lose significant amounts of energy in traversing the cavity and travel in a straight line. The error in incorrectiy analyzing heavy ions which start or stop in the gas is small for radiation protection purposes (Rossi 1968).

The reader is directed to detailed discussions of these concepts (Rossi 1968, ICRU 1977, Kellerer 1970). Suffice it to say that the assumptions lead to small errors in dose and somewhat larger errors in dose equivalent. Errors from Poisson treatment of individual events will be noted within the report.

\section{QUALITY FACTOR AND DOSE EQUIVALENT}

In 1963, the Relative Biological Effectiveness (RBE) Comittee recommended to the ICRP and ICRU a means by which doses of radiation of different quality might be added. In order to avert the confusion between the RBE concept used in radiobiology and the LET dependent factor for dose activity, the ICRU (1963) coined the term quality factor and defined it as follows:

\footnotetext{
"[The ICRU] now recommends that the term RBE be used in radiobiology only and that another name be used for the linear-energytransfer-dependent factor by which absorbed doses are to be multiplied to obtain, for purposes of radiation protection, a quantity that expresses, on a common scale for all ionizing radiations, the irradiation incurred by exposed persons. The name recommended for this factor is the quality factor (QF)."
}

The values of quality factor are based on average linear energy transfer (LET) (RBE 1963). The LET is equal to the "stopping power" in water for the charged particles. Based on the RBE Committee recommendations, ICRP and ICRU adopted quality factor determinations that were based on LET as recommended by the RBE Committee. Those values are found in Table 5 (RBE 1963, 
TABLE 5. LET-QF Relationship (RBE 1963)

\begin{tabular}{|c|c|}
\hline $\begin{array}{l}\text { LET } \\
(\mathrm{keV} / \mu \text { in water })\end{array}$ & QF \\
\hline 3.5 or less & 1 \\
\hline $3.5-7.0$ & $1-2$ \\
\hline $7.0-23$ & $2-5$ \\
\hline $23-53$ & $5-10$ \\
\hline $53-175$ & $10-20$ \\
\hline
\end{tabular}

ICRU 1969, ICRP 1973). The dose equivalent is then the product of the absorbed dose and the quality factor and any other pertinent modifying factors (ICRU 1976).

Unfortunately, the difficulties associated with the observation of LET distributions (i.e., statistical spread of energy loss; track diameter and curvature) make LET impossible to measure directly (ICRU 1969). Because of these limitations, Rossi defined the quantity, $Y$ (event size), the analog of $\overline{L E T}$, and showed its relationship to LET (Rossi 1968). Beyond that, Kellerer derived a relationship between $y_{D}$, the average lineal energy in the dose distribution, and $L_{D}$, the dose mean of LET distribution (Kellerer 1970). The point of all this work was to use an observable quantity to determine a quantity which is impossible to measure. The definitions below provide the insight necessary for purposes of this study, however, the reader is directed to the literature for more detailed description of these quantities.

The linear energy transfer is given by:

$$
L=\frac{d E}{d T} \quad \text { (ICRU 1969) }
$$

where $\quad L=$ Tinear energy transfer of a charged particle in a medium, $\mathrm{keV} /$ micrometer

$\mathrm{dE}=$ average energy locally imparted to the medium by the passage of a charged particle of specified energy

dl = distance traversed by the charged particle across the volume of interest. 
The event size is given by:

$$
Y=\frac{E}{d} \quad \text { (Rossi 1968) }
$$

where $\quad Y=$ event size, $\mathrm{keV} /$ micrometer

$$
\begin{aligned}
E= & \text { energy deposited in medium by the passage of a charged } \\
& \text { particle } \\
d= & \text { diameter of the spherical volume of interest. }
\end{aligned}
$$

The lineal energy is given by:

$$
y=\frac{E}{T}
$$

where $\quad y=l$ ineal energy, $\mathrm{keV} /$ micrometer

$E$ = energy deposited by the passage of a charged particle

$T=$ mean chord length of the spherical volume of interest.

The dose distribution is proportional to the product of the 1 ineal energy and the number of events of the given 1 ineal energy, or:

$$
D(y) \propto y * N(y)^{(a)}
$$

where $D(y)=$ dose deposited as a result of lineal energy, $y$, rad

$$
y=\text { lineal energy, } \mathrm{keV} / \text { micrometer }
$$

$$
N(y)=\text { number of lineal energy events of size, } y
$$

The dose weighted mean lineal energy, or average lineal energy is given by:

$$
\bar{y}_{D}=\frac{\int_{y_{1}}^{y_{2}} y D(y) d y}{\int_{y_{1}}^{y_{2}} D(y) d y} \cong \frac{\sum_{y_{1}}^{y_{2}} y D(y)}{\sum_{y_{1}}^{y_{2}} D(y)}
$$

(a) Note: For an exact treatment, see Rossi 1968. 
where $\quad \bar{y}_{D}=$ average lineal energy in the dose distribution between lineal energy events $y_{1}$ and $y_{2}$

$y, D(y)$ are defined previously.

The dose weighted mean lineal energy is related to the dose weighted mean linear energy transfer by:

$$
\bar{y}_{D}=\frac{3}{2} \cdot \frac{\delta_{2}}{d}+\frac{g}{8} \cdot \bar{L}_{D} \quad(\text { Kellerer 1970) }
$$

where $\quad \bar{y}_{D}=$ average 1 ineal energy in the dose distribution where $y_{0} \dot{(}(y)=$ density deposited divided by the mean chord length (equation 7)

$3 / 2 \cdot \delta_{2} / d=$ energy straggling term (neglected for our measurements)

$\overline{\mathrm{L}}_{D}=$ dose mean LET.

Quality factor can be related to linear energy transfer by fitting the published data to the following equation:

$$
Q=A+B \ln \left(T_{D}\right)+C \ln \left(T_{D}\right)^{2}+D \ln \left(\bar{L}_{D}\right)^{3}+E \ln \left(\bar{L}_{D}\right)^{4}
$$

where $\quad Q=$ quality factor

$$
\tau_{D}=\text { dose mean LET (from equation } 8 \text { ) }
$$

and finaliy, the dose equivalent may be determined by

$$
H=Q \cdot \int_{y_{1}}^{y_{2}} D(y) d y \approx Q \sum_{y_{1}}^{y_{2}} D(y) \text { or } \sum_{y_{1}}^{y_{2}} Q(y) \cdot O(y)
$$

(a) Note: This is an analytical fit to figure 2 in ICRP 21 (ICRP 1973). Other approximations have been reconmended as well, but it was just as easy to employ this formula since the data reduction was performed by computer. 


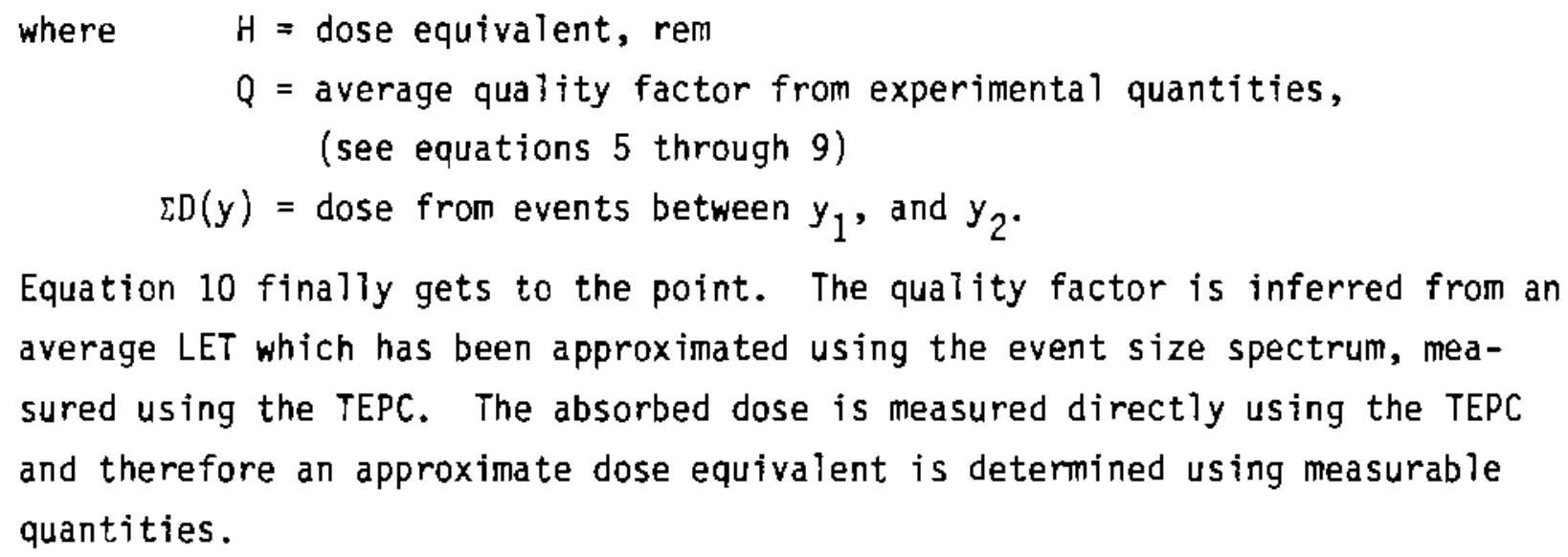




\section{DATA ANALYSIS}

\section{COMPUTER CODE}

As was mentioned earlier, pulses produced by the charged secondary particles are amplified by an electronic preamplifier and a linear amplifier and stored in a multichannel analyzer. The data (counts per channel) are usually transferred to cassette tape and later, to computer disk file. A description of the data analysis follows and a brief flow chart is given in Figure 6.

The data at this point reside on a 5-in. floppy disk in the form of three parameters: (1) the number of channels (e.g., 2048), (2) measurement title, and (3) a serial array in which is contained the number of counts in each channel.

When analyzing data, the operator is queried about certain operating parameters (i.e., the counter diameter, gas filling pressure and temperature at time of gas fill). These parameters are used in equation (11) to determine the mass of the gas.

$$
0=1.602 \times 10^{-8} \sum_{h 1}^{h 2} c \cdot h \cdot N(h) \cdot(V)^{-1} \cdot(0)^{-1} \text { (ICRU 1977) }
$$

where

$$
\begin{aligned}
D & =\text { absorbed dose, rad } \\
C & =\text { channel to energy calibration, MeV/micrometer } \\
\mathrm{h} & =\text { channel number } \\
\mathrm{N}(\mathrm{h}) & =\text { counts in channel } \mathrm{h} \\
\mathrm{h} 1 & =\text { starting data channel } \\
\mathrm{h} 2 & =\text { ending data channe } \\
V & =\text { gas volume, cubic centimeters } \\
D & =\text { gas density, g/cubic centimeter }
\end{aligned}
$$

The counter diameter is used to determine the volume of the counter while the pressure and temperature are used to correct the density. Volume times density equals the mass of gas in the counter, or

$$
M(g)=\rho(g / c c) \cdot V(c c)
$$




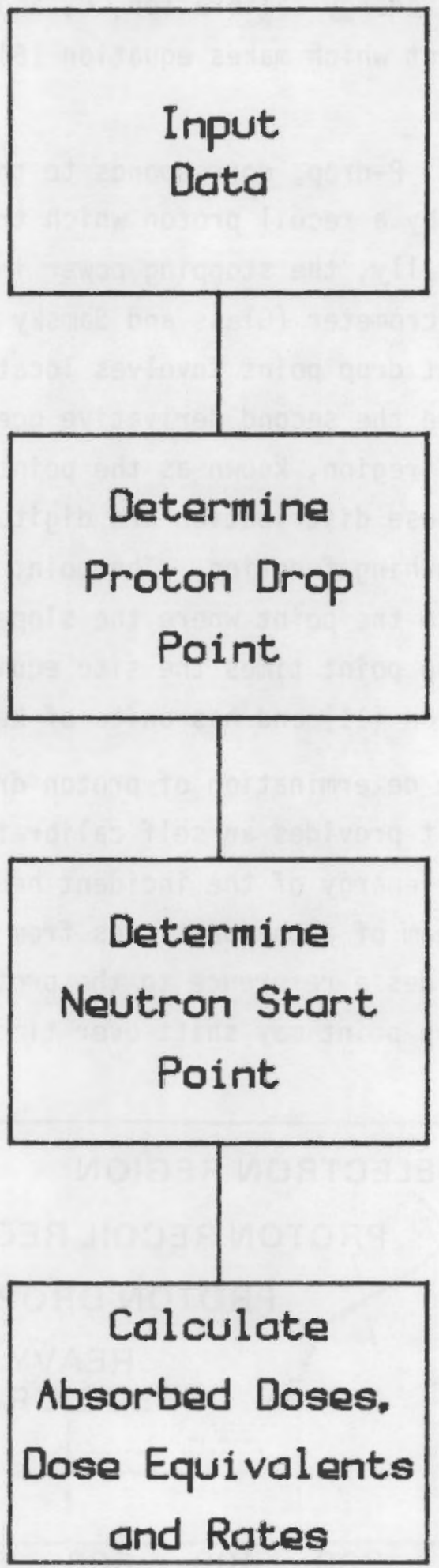

FIGURE 6. TEPC Anaiys is Flow Chart 
The constant $1.602 \times 10^{-8}$, energy calibration, $C$, and the mass are included in the proportionality constant which makes equation (6) an equality instead of just a proportionality.

The proton drop point, P-drop, corresponds to the maximum LET, or stopping power, exhibited by a recoil proton which traverses the diameter of the cavity. More specifically, the stopping power in the gas is at a maximum for protons at $\sim 100 \mathrm{keV} /$ micrometer (Glass and Samsky 1967). The technique used to determine the point drop point involves locating the point in the dose distribution $[h \cdot N(h)]$ where the second derivative goes through a minimum just below the heavy ion recoil region, known as the point of inflection. The individual values in the dose distribution are digitally filtered for smoothness using a 15 point smoothing function. The point of inflection, identified in Figure 7, corresponds to the point where the slope of the curve changes direction. The proton drop point times the site equivalent diameter corresponds to the "c" in equation (11) and has units of $\mathrm{keV} / \mathrm{channel}$.

The importance of the determination of proton drop point cannot be overstated. On the one hand it provides an self calibration pcint for the TEPC that is independent of the energy of the incident neutron and hence, the calibration source. (A beam of alpha particles from a ${ }^{244} \mathrm{Cm}$ source internally fixed in the counter provides a reference to the proton drop point.) On the other hand, the proton drop point may shift over time due to gain shifts in

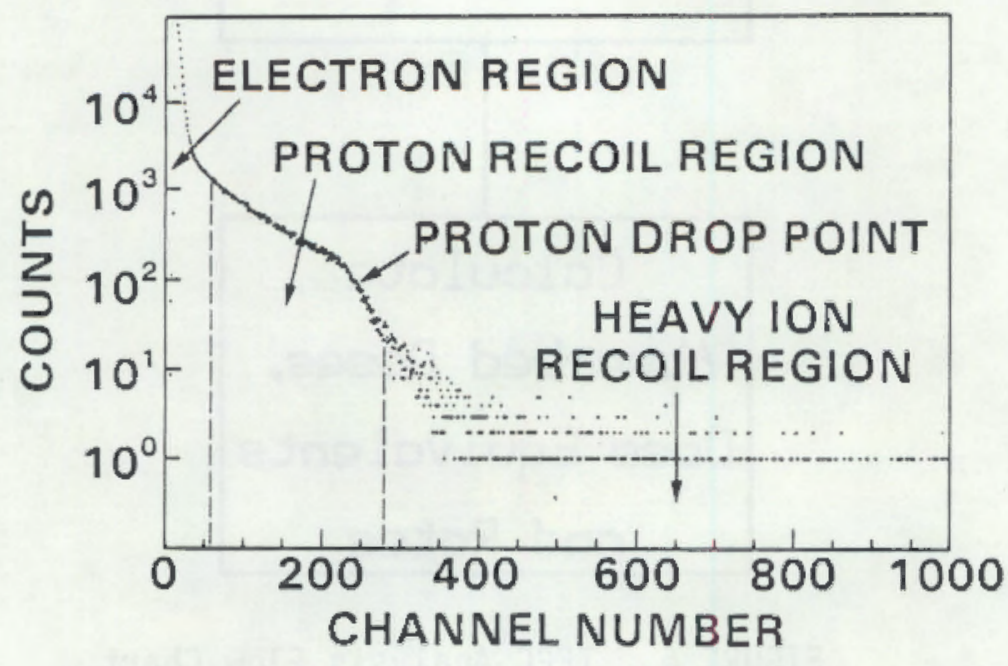

FIGURE 7. Raw Data Spectrum from a Reactor Measurement Using the TEPC 
the counting system (most noticeably from temperature effects in electronic components) and one may not be abie to determine a sharply defined P-drop. Also, statistical variations in the count distributions of low dose measurements may lead to incorrect P-drops. Generally, the determination of the P-drop is stable and accurate enough for personnel dosimetry purposes. For example, if a small integral absorbed dose is measured (i.e., <10 mrad) the deviation in measurement statistics (30-40\%) would greatly overshadow the effect of misplacing the proton drop point by a few percent labsorbed dose is proportional to the location of the proton drop point through the conversion of channel to pulse height).

The discrimination of events due to electrons traversing the cavity from events due to protons traversing the cavity at small lineal energies $(210 \mathrm{keV} / \mu)$ is difficult. Typically the techniques include: (1) the subtraction of a previously stored spectrum of events due to photon interactions in the counter wall; (2) the determination of the minimum between the two regions in the $y$-squared distribution (the $y$-squared distribution is the distribution of $y \cdot D(y)$ or $y \cdot y \cdot N(y)$ (Figure 8) and assumption that events which are to the left of that point (less eneroetic) are due to photon interactions and events to the right of that point (more energetic) are due to neutrons; (3) finding the respective slopes of the curves (in the y-squared distribution) on either side of the minimum and calculate doses by extrapolation of those curves; and (4) setting a default value (e.g. $7 \mathrm{keV} / \mathrm{micrometer} \mathrm{from}$ ${ }^{252}$ Cf irradiation) above which events are assumed to be due to neutron interactions and below which events are assumed to be due to photon interactions. The development of techniques 1 and 3 were sufficiently complex to be outside the scope of this study, so only techniques 2 and 4 were used subject to the following criteria. If the second technique is not feasible due to too little data, or not enough spread (e.g., proton drop point too low) then the fourth technique will be employed during this study. Additionally, an attempt wili be made to present and discuss the photon induced events and doses. 


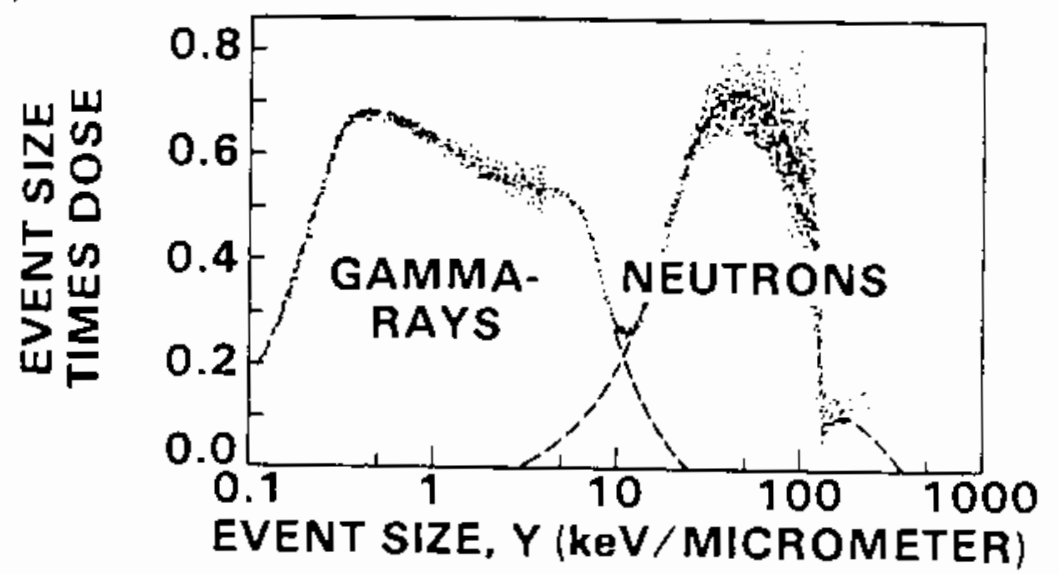

FIGURE - 6 . Neutron and Gamma Dose Measured by the Tissue Equivalent Proportional Counter

The calculation of neutron absorbed dose is straightforward and is performed using equation (1). Two methods were used to determine a quality factor from the dose spectra, the Kellerer approximation and the Borak approximation. The kellerer approximation involved finding the average event size/linear energy transfer as enumerated in equations (7) through (9) and applying a fourth order polynomial of the log of average linear energy transfer. The Borak approximation determined dose equivalent by applying the same equation to each event size and integrating the individual products of quality factor, event size, and number of events of the particular size, equation (11) (Borak and Stinchcomb 1982). 
NBS $-{ }^{252}$ CF IRRADIATIONS

Two sources were used at the NBS to irradiate the TEPC: NS-79 in the bare ${ }^{252} \mathrm{Cf}$ configuration and NS-86 in the $\mathrm{D}_{2} 0$-moderated ${ }^{252} \mathrm{Cf}$ configuration. The TEPC was placed at $81.4 \mathrm{~cm}$ from the source for the bare ${ }^{252} \mathrm{Cf}$ irradiation and at $56.4 \mathrm{~cm}$ from the source for the moderated ${ }^{252} \mathrm{Cf}$ irradiation. The data are summarized in Table 6 .

The TEPC used at NBS for these measurements was a 5-in. diameter spherical counter (\#502) manufactured by Far West Technologies (FWT). The signal was amplified using an Ortec preamp (142-PC) and ampiifier (Ortec 572). Data were collected and stored in a Canberra-Series $40^{\circ}$ multichannel analyzer and subsequently written to cassette tape (see Figure 1).

TABLE 6. Neutron Dose Measurements on Bare and Moderated ${ }^{252} \mathrm{Cf}$ at NBS

\begin{tabular}{|c|c|c|c|c|c|c|c|}
\hline & $\begin{array}{c}\text { Source } \\
\text { Configuration } \\
\end{array}$ & $\begin{array}{c}\text { Absorbed Dose Rate } \\
\text { (mrad/hr) }\end{array}$ & $\begin{array}{l}\text { Quality } \\
\text { Kellerer }\end{array}$ & $\begin{array}{l}\text { Factor } \\
\text { Borak }\end{array}$ & $\begin{array}{l}\text { IEPC } \\
\text { DE Rate } \\
\text { (mrem/hr) }\end{array}$ & $\begin{array}{c}\text { Del ivered } \\
\text { DE Rate } \\
\text { (mrem/hr) }\end{array}$ & $\begin{array}{c}\text { Ratio } \\
\text { IEPC/Delivered } \\
\end{array}$ \\
\hline Gamma & Bare & $22.1 \pm 2.76^{(0)}$ & 1.0 & 1.2 & $22-26$ & $42^{(b)}$ & $0.53-0.62$ \\
\hline Neutron & Bare & $59.4 \pm 3.48$ & 8.8 & 10.0 & $523-594$ & $595^{(c)}$ & $0.88-1.00$ \\
\hline Gomms & $\mathrm{D}_{2} 0$-moderated & $45.6 \pm 3.97$ & 1.0 & 1.4 & $46-64$ & $116^{(d)}$ & $0.40-0.55$ \\
\hline Neutron & $\mathrm{D}_{2}{ }^{\mathrm{O} \text {-moderated }}$ & $61.1 \pm 3.60$ & 9.2 & 10.4 & $562-611$ & $645^{(c)}$ & $0.87-0.95$ \\
\hline
\end{tabular}

(a) One standard deviation from Poisson statistícs.

(b) From Stoddard and Hootman 1971.

(c) Supplied by NBS.

(d) From McDonald et al. 1983.

PNL $-{ }^{252}$ CF IRRADIATIONS

PNL possesses a $15-\mathrm{Cm} \mathrm{D}_{2} 0$-moderated ${ }^{252} \mathrm{Cf}$ source in a low-scatter irradiation facility. The $\mathrm{D}_{2} \mathrm{O}$ is contained in a $0.8-\mathrm{mm}$ thick stainless steel shell surrounded with a $0.5-\mathrm{mm}$ thick cadmium shell. The design and construction of the source is similar enough to the source described by Schwartz and Eisenhauer (1980) that the reader is directed to that document for further detail. 
The moderated ${ }^{252} \mathrm{Cf}$ source was used at the PNL-Calibration Facility to irradiate the TEPC in order to compare to the NBS measurements. The TEPC which was used was an optimized low-noise, self-contained, 2-1/4-inch diameter, spherical TEPC manufactured by EG\&G, Santa Barbara in conjunction with Far West Technologies. The TEPC was placed at 1 meter from the source for all irradiations. The data are summarized in Table 7.

TABLE 7. Neutron Dose Measurements on Moderated ${ }^{252} \mathrm{Cf}$ at PNL

\begin{tabular}{|c|c|c|c|c|c|c|c|}
\hline & $\begin{array}{c}\text { Source } \\
\text { Configuration } \\
\end{array}$ & $\begin{array}{c}\text { Absorbed Dase Rate } \\
(\mathrm{mrad} / \mathrm{hr}) \\
\end{array}$ & $\begin{array}{l}\text { Qual ity } \\
\text { Kellerer }\end{array}$ & $\frac{\text { Factor }}{r \text { Borak }}$ & $\begin{array}{l}\text { TEPC } \\
\text { DE Rate } \\
\text { (mrem/hr) }\end{array}$ & $\begin{array}{c}\text { Delivered } \\
\text { DE Rate } \\
\text { (mrem/hr) }\end{array}$ & $\begin{array}{c}\text { Ratio } \\
\text { TEPC/Delivered } \\
\end{array}$ \\
\hline Gamma & Bare & $0.89 \neq 0.07^{(a)}$ & 1.0 & 1.2 & 1 & $3^{(b)}$ & 0.33 \\
\hline Neutron & Bare & $4.4 \pm 0.2$ & 8.7 & 9.8 & $36-43$ & $43^{(c)}$ & $0.84-1.00$ \\
\hline Gantina & $\mathrm{D}_{2} \mathrm{O}$-moderated & $23.9 \pm 1.2$ & 1.0 & 1.2 & $24-29$ & $31^{(b)}$ & $0.77-0.94$ \\
\hline Neutron & $\mathrm{D}_{2} \mathrm{O}$-moderated & $22.1 \pm 0.47$ & 8.0 & 9.7 & $177-214$ & $170^{(d)}$ & $1.0-1.3$ \\
\hline
\end{tabular}

(a) From Poisson statistics.

(b) From Stoddard and Hootman 1971.

(c) Suppl jed by PNL.

(d) From MeDonald et al. 1983.

\section{REACTOR IRRADIATIONS}

TEPC measurements were performed at six commercial nuclear power plants during this study, including four PWRs and two BWRs. Data are presented for measurements at four of the plants (two PWRs and two BWRs) as electronic difficulties during one measurement trip interfered with the collection of the TEPC data. The irradiations were performed inside containment of the PWRs and inside the dry wells of the BWRs at various power levels. The low-noise counters which contajned high voltage power supplies and preamps and which were specialiy ordered from EG\&G, Santa Barbara, for this program failed inside some of the plants because of the high temperatures and vibrations encountered. ATI the TEPC measurements were performed with the same $(5-i n$. diameter) counter ( $\$ 502$ ) except those at reactor 4 . The TEPC measurements at reactor 4 were performed using a 5-in. diameter self-contained TEPC \#185. Where possible, multisphere runs and remmeter measurements were performed for comparison. 
Reactor 1

Reactor 1 is a boiling water reactor. The measurements were performed at 60\% power inside the dry we11. The locations constituted various levels above the entry hatch and represented areas workers could be expected to enter. The last measurement (\$4) was performed in the personnel hatch in conjunction with a multisphere measurement. High temperatures, time, and high dose rates prohibited taking high gain measurements at this reactor, so data are presented for neutrons only (Table 8). Additional data regarding average energy, average LET, etc. are presented in the appendix.

TABLE 8. Neutron Dose Measurements for Reactor 1 (BWR)

\begin{tabular}{|c|c|c|c|c|c|c|c|}
\hline Location & $\begin{array}{l}\text { Absorbed } \\
\text { Dose Rate } \\
\text { (mrad/hr) }\end{array}$ & $\begin{array}{l}\text { Quality } \\
\text { Kellere }\end{array}$ & $\begin{array}{l}\text { Factor } \\
\text { I Bordk }\end{array}$ & $\begin{array}{c}\text { TEPC } \\
\text { OE Rate } \\
\text { (mrem/hr) }\end{array}$ & $\begin{array}{l}\text { Reference } \\
\text { DE Rate } \\
\text { (mrem/hr) }\end{array}$ & $\begin{array}{c}\text { Ratio } \\
\text { TEPC-Reference }\end{array}$ & $\begin{array}{l}\text { SNOOPY } \\
\text { (mrem/hr) }\end{array}$ \\
\hline 1 & $13.2 \pm 1.1^{(a)}$ & 8.7 & 10.9 & $115-144$ & - & - & 300 \\
\hline 2 & $6.48 \pm 0.6$ & 8.4 & 10.6 & $54-69$ & - & - & $150-180$ \\
\hline 3 & $137 \pm 27$ & 9.1 & 10.8 & $1240-1480$ & - & - & 2500 \\
\hline 4 & $12.8 \pm 1.5$ & 8.5 & 10.6 & $109-136$ & - & - & 330 \\
\hline 5 & $5.53 \pm 0.5$ & 8.8 & 11.2 & $49-62$ & $49^{(b)}$ & $1-1.27$ & 100 \\
\hline
\end{tabular}

(a) One standard deviation from Poisson statistics.

(b) Multisphere measurement.

Reactor 2

Reactor 2 was also a BWR. Measurements were performed at $10 \%$ power in several locations. High gain measurements were performed enabling analysis of low LET events (below $5 \mathrm{keV} /$ micrometer). The data are presented in Table 9.

TABLE 9. Neutron Dose Measurements for Reactor 2 (BWR)

\begin{tabular}{|c|c|c|c|c|c|c|c|c|}
\hline Location & & $\begin{array}{l}\text { Absorbed } \\
\text { Dose Rate } \\
\text { (mrad/hr) }\end{array}$ & $\begin{array}{l}\text { Quality } \\
\text { Kellerer }\end{array}$ & $\begin{array}{l}\text { Factor } \\
\text { Borak }\end{array}$ & $\begin{array}{c}\text { TEPC } \\
\text { DE Rate } \\
\text { (mrem/hr) }\end{array}$ & $\begin{array}{l}\text { Reference } \\
\text { DE Rate } \\
\text { (mrem/hr) }\end{array}$ & $\begin{array}{c}\text { Ratio } \\
\text { IEPC/Reference }\end{array}$ & $\begin{array}{c}\text { SNOOPY } \\
\text { (mrem/hr) }\end{array}$ \\
\hline 1 & $\begin{array}{l}\text { Gamma } \\
\text { Neutron }\end{array}$ & $\begin{array}{l}232 \pm 31(a) \\
36.5 \pm 2.4\end{array}$ & $\begin{array}{r}1.0 \\
10.1\end{array}$ & $\begin{array}{r}1.3 \\
11.9\end{array}$ & $\begin{array}{l}232-305 \\
369-436\end{array}$ & $\begin{array}{l}470(b) \\
450(c)\end{array}$ & $\begin{array}{l}0.49-0.65 \\
0.82-0.97\end{array}$ & 450 \\
\hline 2 & $\begin{array}{l}\text { Gamma } \\
\text { Neutron }\end{array}$ & $\begin{array}{l}70.7 \pm 8.2 \\
41.5 \pm 3.2\end{array}$ & $\begin{array}{r}1.0 \\
10.9\end{array}$ & $\begin{array}{r}1.4 \\
12.3\end{array}$ & $\begin{array}{r}7 i-101 \\
450-51 \uparrow\end{array}$ & $\begin{array}{l}470^{(b)} \\
450^{(c)}\end{array}$ & $\begin{array}{r}0.15-0.21 \\
1.0-1.14\end{array}$ & 450 \\
\hline 3 & $\begin{array}{l}\text { Ganma } \\
\text { Neutron }\end{array}$ & $\begin{aligned} 113 & \pm 29 \\
1.81 & \pm 0.15\end{aligned}$ & $\begin{array}{l}1.0 \\
9.5\end{array}$ & $\begin{array}{r}1.2 \\
11.7\end{array}$ & $\begin{array}{c}113-132 \\
17-21\end{array}$ & $\begin{array}{l}- \\
-\end{array}$ & $\begin{array}{l}- \\
-\end{array}$ & \\
\hline 4 & $\begin{array}{l}\text { Gamma } \\
\text { Neutron }\end{array}$ & $\begin{aligned} 201 & \pm 50 \\
4.49 & \pm 0.4\end{aligned}$ & $\begin{array}{l}1.0 \\
9.8\end{array}$ & $\begin{array}{r}1.1 \\
11.7\end{array}$ & $\begin{array}{c}201-226 \\
44-53\end{array}$ & $\begin{array}{l}- \\
-\end{array}$ & $\begin{array}{l}- \\
-\end{array}$ & \\
\hline
\end{tabular}

(a) One standard deviation from Poisson statistics.

(b) Portable ion chamber.

(c) Muttisphere measurement. 
Reactor' 3

Reactor 3 is a pressurized water reactor. The two TEPC measurements presented below were performed at $50 \%$ power with corresponding multisphere measurements. The data are summarized in Table 10. Single-gain measurements were performed and while data were insufficient to render an accurate gamma measurement, the gamma data are still presented for comparison purposes.

\section{TABLE 10. Neutron Dose Measurements for Reactor 3 (PWR)}

\begin{tabular}{|c|c|c|c|c|c|c|c|c|}
\hline Location & & $\begin{array}{l}\text { Absorbed } \\
\text { Dose Rate } \\
\text { (mrad/hr) }\end{array}$ & $\begin{array}{l}\text { Qual ity } \\
\text { Kellerer }\end{array}$ & $\begin{array}{l}\text { Factor } \\
\text { Borak }\end{array}$ & $\begin{array}{c}\text { TEPC } \\
\text { DE Rate } \\
\text { (mrem/hr) }\end{array}$ & $\begin{array}{c}\text { Reference } \\
\text { DE Rate } \\
\text { (mrem/hr) }\end{array}$ & $\begin{array}{c}\text { Ratio } \\
\text { TEPC/Reference } \\
\end{array}$ & $\begin{array}{l}\text { SNOOPY } \\
\text { (mrem/hr) }\end{array}$ \\
\hline 1 & $\begin{array}{l}\text { Gamma } \\
\text { Neutron }\end{array}$ & $\begin{array}{l}1.0 \pm 0.3 \\
2.6 \pm 0.2\end{array}$ & $\begin{array}{l}1.2 \\
9.9\end{array}$ & $\begin{array}{l}1.7 \\
11.3\end{array}$ & $\begin{array}{l}12-17 \\
26-29\end{array}$ & $\begin{array}{l}12(a) \\
35(b)\end{array}$ & $\begin{array}{l}1.00-1.42 \\
0.74-0.83\end{array}$ & 55 \\
\hline 2 & $\begin{array}{l}\text { Gamma } \\
\text { Neutron }\end{array}$ & $\begin{array}{l}1.4 \pm 0.3^{(a)} \\
5.6 \pm 0.4\end{array}$ & $\begin{array}{l}1.9 \\
9.7\end{array}$ & $\begin{array}{r}2.5 \\
11.9\end{array}$ & $\begin{array}{l}28-36 \\
54-66\end{array}$ & $\begin{array}{l}50(b) \\
93^{(c)}\end{array}$ & $\begin{array}{l}0.56-0.72 \\
0.64-0.79\end{array}$ & $8 D$ \\
\hline
\end{tabular}

(a) One standard deviation from Poisson statistics.

(b) Portabie ion chamber measurement.

(c) Multisphere measurement.

Reactor 4

Reactor 4 is a pressurized water reactor. The five TEPC measurements were performed in conjunction with the multisphere measurements at $100 \%$ power. Single gain measurements were performed, so the gamma portions of the data below I keV/micrometer are masked by electronic noise. The data are summarized in Table 11.

TABLE 11. Dose Measurements for Reactor 4(PWR)

\begin{tabular}{|c|c|c|c|c|c|c|c|c|}
\hline Location & & $\begin{array}{l}\text { Absorbed } \\
\text { Dose Rate } \\
\text { (mrad/hr) }\end{array}$ & $\begin{array}{l}\text { Quality } \\
\text { Xellerer }\end{array}$ & $\begin{array}{l}\text { Factor } \\
\text { Borak }\end{array}$ & $\begin{array}{c}\text { TEPC } \\
\text { DE Rate } \\
\text { (mrem/hr) } \\
\end{array}$ & $\begin{array}{c}\text { Reference } \\
\text { DE Rate } \\
\text { (mrem/hr) }\end{array}$ & $\begin{array}{c}\text { Ratio } \\
\text { TEPC/Reference } \\
\end{array}$ & $\begin{array}{c}\text { SNOOPY } \\
(\mathrm{mrem} / \mathrm{hr})\end{array}$ \\
\hline 1 & $\begin{array}{l}\text { Gamma } \\
\text { Neutron }\end{array}$ & $\begin{array}{l}3.0 \pm 1.4 \\
0.9 \pm 0.1\end{array}$ & $\begin{array}{l}1.0 \\
8.4\end{array}$ & $\begin{array}{r}1.4 \\
10.5\end{array}$ & $\begin{array}{l}3-4 \\
8-10\end{array}$ & $1 \overline{-}$ & $0.47-0.59$ & 27 \\
\hline 2 & $\begin{array}{l}\text { Gamma } \\
\text { Neutron }\end{array}$ & $\begin{array}{l}3.7 \pm 1.7 \\
0.9 \pm 0.1\end{array}$ & $\begin{array}{l}1.8 \\
8.5\end{array}$ & $\begin{array}{r}2.3 \\
10.8\end{array}$ & $\begin{array}{l}6-8 \\
8-10\end{array}$ & $1 \overline{-}$ & $\begin{array}{c}- \\
0.67-0.83\end{array}$ & $1 \overline{5}$ \\
\hline 3 & $\begin{array}{l}\text { Gamma } \\
\text { Neutron }\end{array}$ & $\begin{array}{l}8.3 \pm 4.2 \\
1.3 \pm 0.1\end{array}$ & $\begin{array}{l}1.0 \\
8.2\end{array}$ & $\begin{array}{r}1.2 \\
10.3\end{array}$ & $\begin{array}{r}8-10 \\
11-13\end{array}$ & $\overline{16}$ & $\begin{array}{c}- \\
0.69-0.81\end{array}$ & 33 \\
\hline 4 & $\begin{array}{l}\text { Gamma } \\
\text { Neutron }\end{array}$ & $\begin{array}{r}10.8 \pm 4.2 \\
3.0 \pm 0.2\end{array}$ & $\begin{array}{l}1.3 \\
9.6\end{array}$ & $\begin{array}{r}1.8 \\
11.7\end{array}$ & $\begin{array}{l}31-15 \\
29-35\end{array}$ & 35 & $\begin{array}{c}- \\
0.83-1.00\end{array}$ & 68 \\
\hline 5 & $\begin{array}{l}\text { Gamma } \\
\text { Neutron }\end{array}$ & $\begin{array}{l}2.6 \pm 0.7 \\
1.3 \pm 0.1\end{array}$ & $\begin{array}{l}1.3 \\
8.7\end{array}$ & $\begin{array}{r}1.8 \\
10.8\end{array}$ & $\begin{array}{c}3-4 \\
12-14\end{array}$ & $1 \overline{6}$ & $\begin{array}{c}- \\
0.75-0.88\end{array}$ & $5 \overline{3}$ \\
\hline
\end{tabular}




\section{DISCUSSION OF RESULTS}

The results of these measurements lead to several conclusions regarding dose measurements employing the TEPC. The results and conclusions will be discussed from the perspectives of 1) neutron measurements and 2) gamma measurements.

\section{NEUTRON MEASUREMENTS}

The neutron measurements performed using the TEPC were all in good agreement with reference measurements. Table 12 summarizes the average ratios of TEPC measurements to the reference dose equivalents for the laboratory irradiations and the reactor measurements.

TABLE 12. Average Ratio of TEPC Dose Equivalent to Reference Dose Equivalent

$\begin{array}{cccc}\text { Irradiation } & \begin{array}{c}\text { Kellerer } \\ \text { Approximation }\end{array} & \begin{array}{c}\text { Borak } \\ \text { Approximation }\end{array} \\ & 0.91 \pm 0.09 & & 1.05 \pm 0.14 \\ { }^{252} \mathrm{Re} & 0.71 \pm 0.15 & 0.86 \pm 0.20\end{array}$

The ratio of the TEPC determined dose equivalents to reference dose equivalents could have been improved for reactor measurements if ionger counting times and higher integral doses could have been attained. The measurements were constrained by the effects of heat (upon the researchers as well as upon the instruments), ALARA, and the overall lack of locations with high neutron dose rates. Additionaliy, the heat appears to have affected the multisphere measurements at Site 1 by broadening the thermal neutron peak obtained from the LiI detector.

Examination of the renmeter data taken in conjunction with these measurements reveals that the SNOOPY remmeter responded $71 \%$ higher than the multispheres $(1.71 \pm 0.74)$ and approximately $100 \%$ higher than the TEPC (1.99 \pm 0.78). These results are in excellent agreement with earlier results (Endres et a1. 1981, Schwartz et a1. 1982, Cummings et a 1. 1980). Schwartz published a value of 1.66 as the ratio of the responses of a cylindrical remmeter 
(similar to the one used in this study) to bare and $\mathrm{O}_{2} \mathrm{O}$-moderated ${ }^{252} \mathrm{Cf}$ $\left(O E_{\mathrm{O}_{2} \mathrm{O}}-\mathrm{Cf} / \mathrm{OE} \mathrm{Bare}_{\mathrm{Cf}}=1.66\right.$, Schwartz et a1. 1982). Further it was recommended by Schwartz et a T. (1982) that remmeters be calibrated using the specified $\mathrm{D}_{2} 0$-moderated ${ }^{252} \mathrm{Cf}$ source. These data support that conclusion, but cautiously, as the average ratio of remmeter measurement to reference measurement carried with it a large standard deviation. (The remmeter used in this task had been calibrated using a bare ${ }^{252} \mathrm{Cf}$ source.)

\section{GAMMA MEASUREMENTS}

The gamma measurements performed with the TEPC were very poor. The main reason that the counter could not accurately assess gamma dose was that electronic noise limited the minimum event size that could be measured.

The electronic noise was caused by three major components of the TEPC system. First, since larger counters (5-in. diameter) were used to increase sensitivity and decrease stay time, there was a larger degree of electronic noise produced by the counter/preamp combination and long signal cables. Secondly, problems with the internal calibration sources and high voltages in self-contained TEPCs forced the use of the older style laboratory counters for reactor measurements, which introduced more noise from the external preamp and high voltage power supplies. (The problems associated with the self-contained TEPCs have been corrected on the later models which have since been produced by EG\&G and Far West Technologies.) Third, research amplifiers were aiso slightly noisier due to the heat encountered inside the reactors.

The magnitude of this effect for gamma dose analysis is seen by examining the $\mathrm{y} \cdot \mathrm{O}(\mathrm{y})$, or $\mathrm{y}^{2} \mathrm{~N}(\mathrm{y})$ distributions for $\mathrm{x}$ rays published by $\mathrm{Kl}$ iauga and Dvorak (1978) (Figure 9). The data need to be analyzed between 0.1 and $20 \mathrm{keV} / \mathrm{micro-}$ meter in order to accurately assess dose.

The best measurement that the authors could obtain for this study, using a low noise, 2-1/4-in. diameter TEPC in a low-scatter calibration facility, is depicted in Figure 10 (from appendix, Figure A.12). The lowest event size which could be reached proved to be $0.3 \mathrm{keV} /$ micrometer. (The peak at $\sim 0.2 \mathrm{keV}$ / micrometer is electronic noise.) The constrictions of heat and vibration made that goal unattainable for the reactor measurements. At present, the TEPC can not be used to accurately measure dose from photon induced events in reactor environments for the foregoing reasons. 


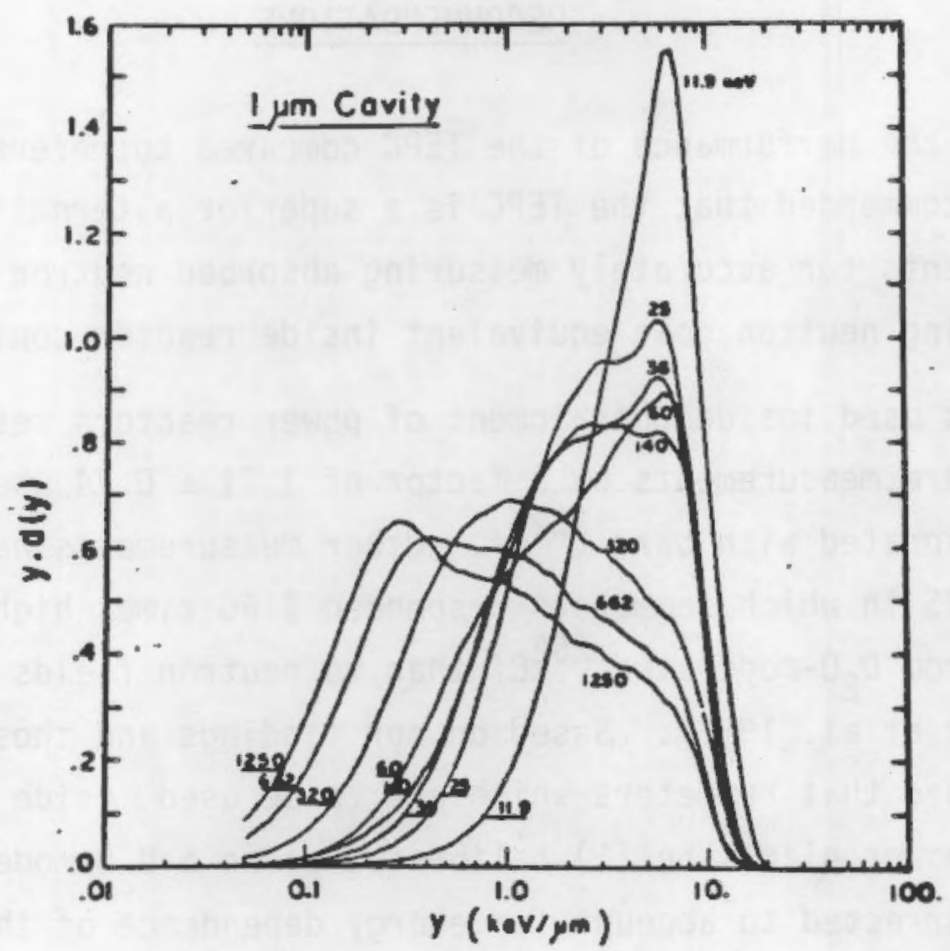

FIGURE 9. The Distribution $y^{2} N(y)$ as a Function of $Y$ for a 1-um Simulated Cavity at Eight Photon Energies (From Kliagua and Dvorak 1978)

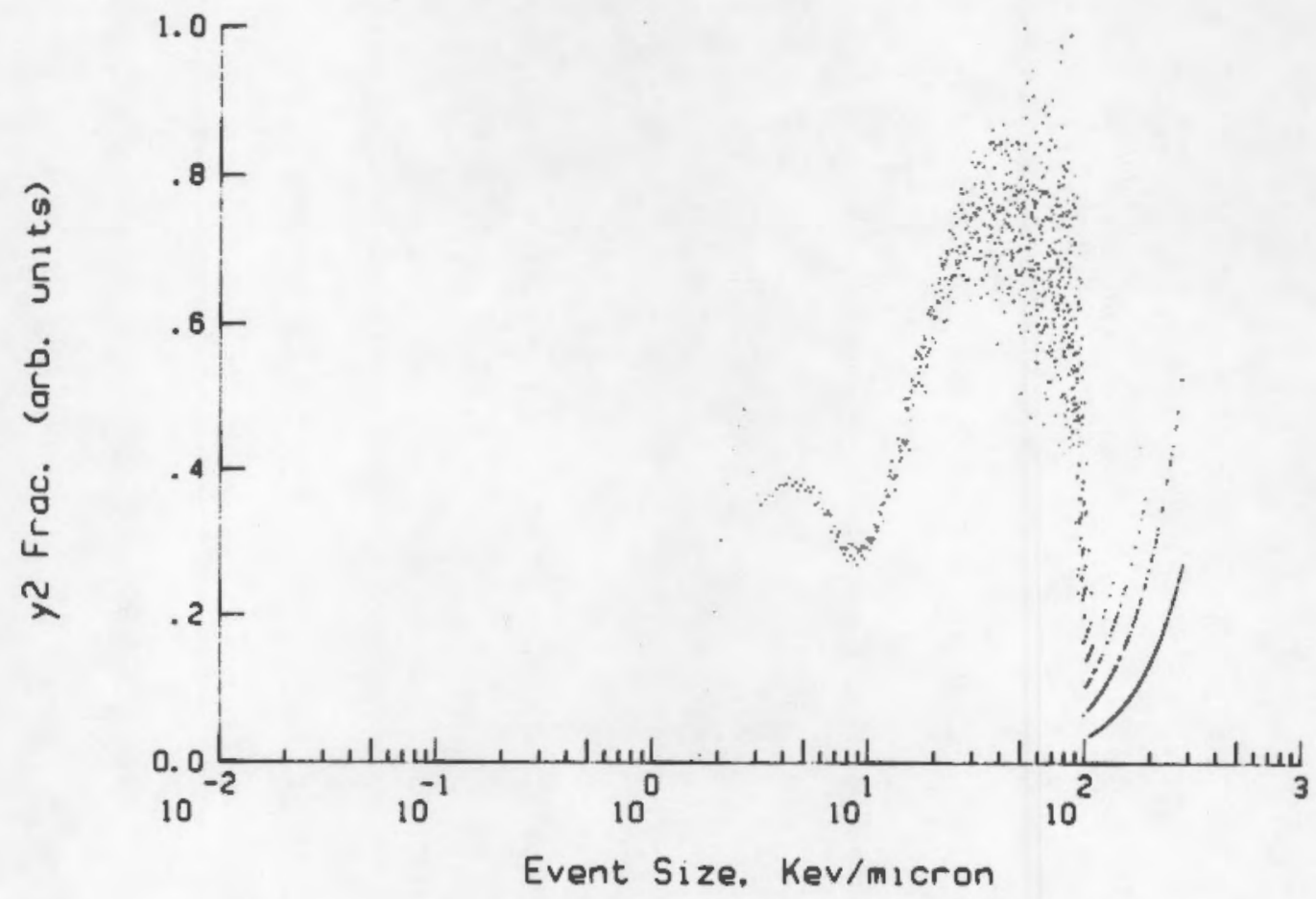

FIGURE 10. $y^{2} \mathrm{~N}(\mathrm{y})$ Distribution from a $\mathrm{D}_{2} \mathrm{O}$-Moderated ${ }^{252} \mathrm{Cf}$ Source 


\section{RECOMMENDATIONS}

- Based on the performance of the TEPC compared to reference measurements, it is recommended that the TEPC is a superior alternative to multisphere measurements for accurately measuring absorbed neutron dose and determining neutron dose equivalent inside reactor containment.

- Remmeters used inside containment of power reactors responded higher than multisphere measurements by a factor of $1.71 \pm 0.74$ when the remmeters were calibrated with bare ${ }^{252} \mathrm{Cf}$. Other measurements have been performed at the NBS in which remmeters responded 1.66 times higher to neutron fields from $\mathrm{D}_{2} \mathrm{O}$-moderated ${ }^{252} \mathrm{Cf}$ than to neutron fields from bare ${ }^{252} \mathrm{Cf}$ (Schwartz et al. 1982). Based on our findings and those results, it is recommended that remmeters which are to be used inside containment of nuclear power plants be (1) calibrated using a $\mathrm{D}_{2} \mathrm{O}$-moderated ${ }^{252} \mathrm{Cf}$ source or (2) corrected to account for energy dependence of the remmeter.

- It is recommended at this time that the TEPC not be used to assess absorbed gamma dose and gamma dose equivalent inside reactor containment. 


\section{REFERENCES}

Borak, T. B., and T. G. Stinchcomb. 1982. "Errors in Estimating Neutron Quality Factor Using Lineal Energy Distributions Measured in TissueEquivalent Proportional Counters." Health Phys. 43:2.

Cosack, M., and H. Lesiecki. 1981. "Dependence of the Response of Eight Neutron Dose Equivalent Survey Meters with Regard to the Energy and Direction of Incident Neutrons." Contributed to the Fourth Symposium on Neutron Dosimetry, Neuherberg, Germany.

Cummings, F. M., G. W. R. Endres and L. W. Brackenbush. 1983. Neutron Dosimetry at Commercial Nuclear Plants--Final Report of Subtask B: Dosimeter Response. NUREG/CR-1769, U.S. Nuclear ReguTatory Commission, Washington, D.C.

Endres, G. W. R., J. M. Aldrich, L. W. Brackenbush and R. V. Griffith. 1981. Neutron Dosimetry at Commercial Nuclear Plants--Final Report of Subtask A: Reactor Containment Measurements. NUREG/CR-1769, U.S. Nuclear Regulatory Cominission, Washington, D.C.

Evans, R. D. 1955. The Atomic Nucleus. McGraw-Hill, Inc., New York.

Evans, R. D. 1968. "x-Ray and $Y$-Ray Interactions," in Radiation Dosimetry, Vol. 1, F. H. Attix, W. C. Roesch and E. Tochilin, eds. Academic Press, New York.

Failia, G., and H. H. Rossi. 1950. "Dosimetry of Ionizing Particles." Am. J. Roentgenol. 64:489.

Glass, W. A., and D. N. Samsky. 1967. "Ionization in Thin Tissue-Like Gas Layers by Monoenergetic Protons." Rad. Res. 32:138.

Hankins, D. E. 1977. "Energy Dependence Measurements of Rem-Meters and Albedo Dosimeters at Neutron Energies of Thermal and Between 2 keV and $5.67 \mathrm{MeV}, "$ p.553 in Proceedings of the International Radiation Protection Association's IV International Congress, Paris, France.

International Commission on Radiological Protection (ICRP). 1973. Data for Protection Against Ionizing Radiation From External Sources: Supplement to ICRP PubTication 15. ICRP Publication 21, International Commission on Radiological Protection, 7910 Woodmont Avenue, Washington, D.C.

International Commission on Radiological Units and Measurements (ICRU). 1962. Physical Aspects of Irradiation. ICRU Publication 10b, 7910 Woodmont Avenue, Washington, D.C.

International Commission on Radiological Units and Measurements (ICRU). 1969. Linear Energy Transfer. ICRU Publication 16, 7910 Woodmont Avenue, Washington, D.C. 
International Comnission on Radiological Units and Measurements (ICRU). I976. Radiation Protection Instrumentation and Its Application. ICRU Publication 20, 7910 Woodmont Avenue, Washington, D.C.

International Commission on Radiological Units and Measurements (ICRU). 1977. Neutron Dosimetry for Biology and Medicine. ICRU Publication 26, 7910 Woodmont Avenue, Washington, D.C.

Kellerer, A. 1970. "Analysis of Pattern of Energy Deposition," in Microdosimetry, Second Symposium, EURATOM Report EUR4452, d-f-e, EURATOM, Brussels.

Kliauga, P., and R. Dvorak. 1978. "Microdosimetric Measurements of Ionization by Monoenergetic Photons." Rad. Res. 73:1-20.

Kno11, G. F. 1979. Radiation Detection and Measurement. John Wiley and Sons, New York.

McDonald, J. C., R. V. Griffith, P. Plato and J. Miklos. 1983. Measurements of Gamma-Ray Dose From a Moderated 252-Cf Source. NUREG/CR-2957, U.S. Nuclear Regulatory Commission, Washington, D.C.

National Bureau of Standards (NBS). 1961. Measurements of Absorbed Dose of Neutrons, and of Mixtures of Neutrons and Gamma Rays. NBS Publication 25, Department of Commerce, Washington, D.C.

Srdoc, D. 1970. "A miniature X-Ray Calibration Tube." In Annual Report on Research Project, NYO-2740-5, pg. 22, Radiological Research Laboratory, Columbia University, New York.

Relative Biological Effectiveness Committee. 1963. "Report of the RBE Committee to the International Commissions on Radiological Protection and on Radiological Units and Measurements." Health Phys. 9:4(357).

Rossi, H. H. 1968. "Microscopic Energy Distribution in Irradiated Matter," in Radiation Dosimetry, Vol. 1, F. H. Attix, W. C. Roesch and E. Tochilin, eds. Academic Press, New York.

Schwartz, R. B., and $C$. M. Eisenhauer. 1980. The Design and Construction of a $D_{2} 0$-Moderated ${ }^{252} \mathrm{Cf}$ Source for Calibrating Neutron Personnel Dosimeters Used at Nuclear Power Reactors. NUREG/CR-1204, U.S. Nuclear Regulatory Commission, Washington, D.C.

Schwartz, R. B., G. W. R. Endres and F. M. Cummings. 1982, Neutron Dosimeter Performance and Associated Calibrations at Nuclear Power Plants. NUREG/ CR-2233, U.S. Nuclear Regulatory Commission, Washington, D.C.

Stoddard, D. H., and H. E. Hootman. 1971. ${ }^{252} \mathrm{Cf}$ Shielding Guide. U.S.A.E.C. Report DP-1246. 


\section{APPENDIX}

SUMMARY NEUTRON MEASUREMENTS 
TABLE A.1. NBS Bare ${ }^{252} \mathrm{Cf}$ Neutron Measurements

Source \#

NS-79

$$
\frac{\begin{array}{c}
\text { Emission Rate } \\
(\mathrm{n} / \mathrm{sec})
\end{array}}{4.13 \times 10^{8}}
$$

Site Equivalent Diameter (micrometers)

1.0

\author{
Neutron \\ DE Rate at $1 \mathrm{~m}$ \\ (mrem/hr)
}

394
Date

$3 / 28 / 83$
TEPC \#

502

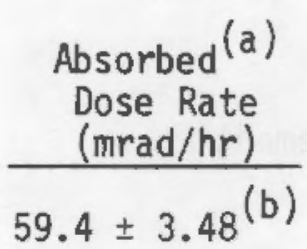

Kellerer Approximation

\begin{tabular}{c}
$\begin{array}{c}\text { Average } \\
\text { Quality }\end{array}$ \\
$\begin{array}{c}\text { Dose Equivalent } \\
\text { Rate } \\
\text { Factor }\end{array}$ \\
\hline
\end{tabular}

8.8

523

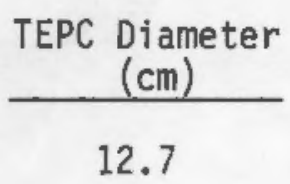

TEPC Diameter

12.7
Live Time (sec)

3600

\section{Proton Drop \\ Point Channel \#}

353
Calibration

Constant

(keV/micron/channel)

0.2858

$\frac{\begin{array}{c}\text { Total } \\ \text { Neutron Events } \\ \text { (Counts) }\end{array}}{1.13 \times 10^{6}}$

$\frac{(\mathrm{keV} / \text { micron) }}{50.4}$

Borak Approximation \begin{tabular}{lc}
\hline Average & Dose Equivalent \\
Quality & Rate \\
Factor & (mrem/hr) \\
\hline
\end{tabular}

10.0 594
Average

Event Size (Frequency) (keV/micron)

$$
27.7
$$

Average Event Size (Dose) (keV/micron)

50.4

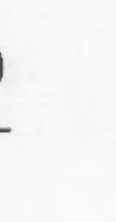

Average

44.8

$\underline{\text { (keV/micron) }}$

(a) Dose rate at $81.4 \mathrm{~cm}$.

(b) One standard deviation from Poisson statistics. 


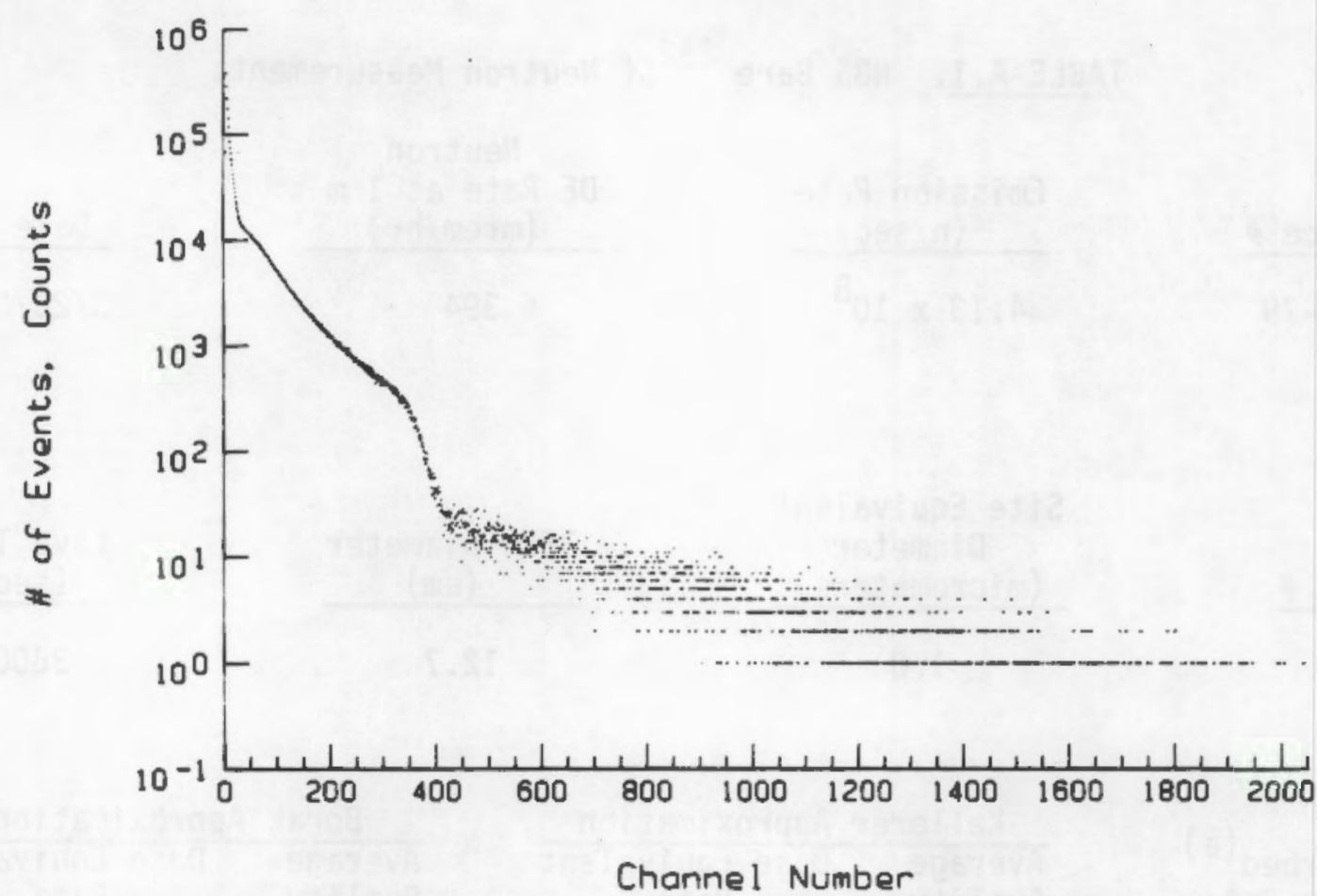

FIGURE A.1. Raw Data for NBS Bare ${ }^{252}$ Cf Neutron Measurement

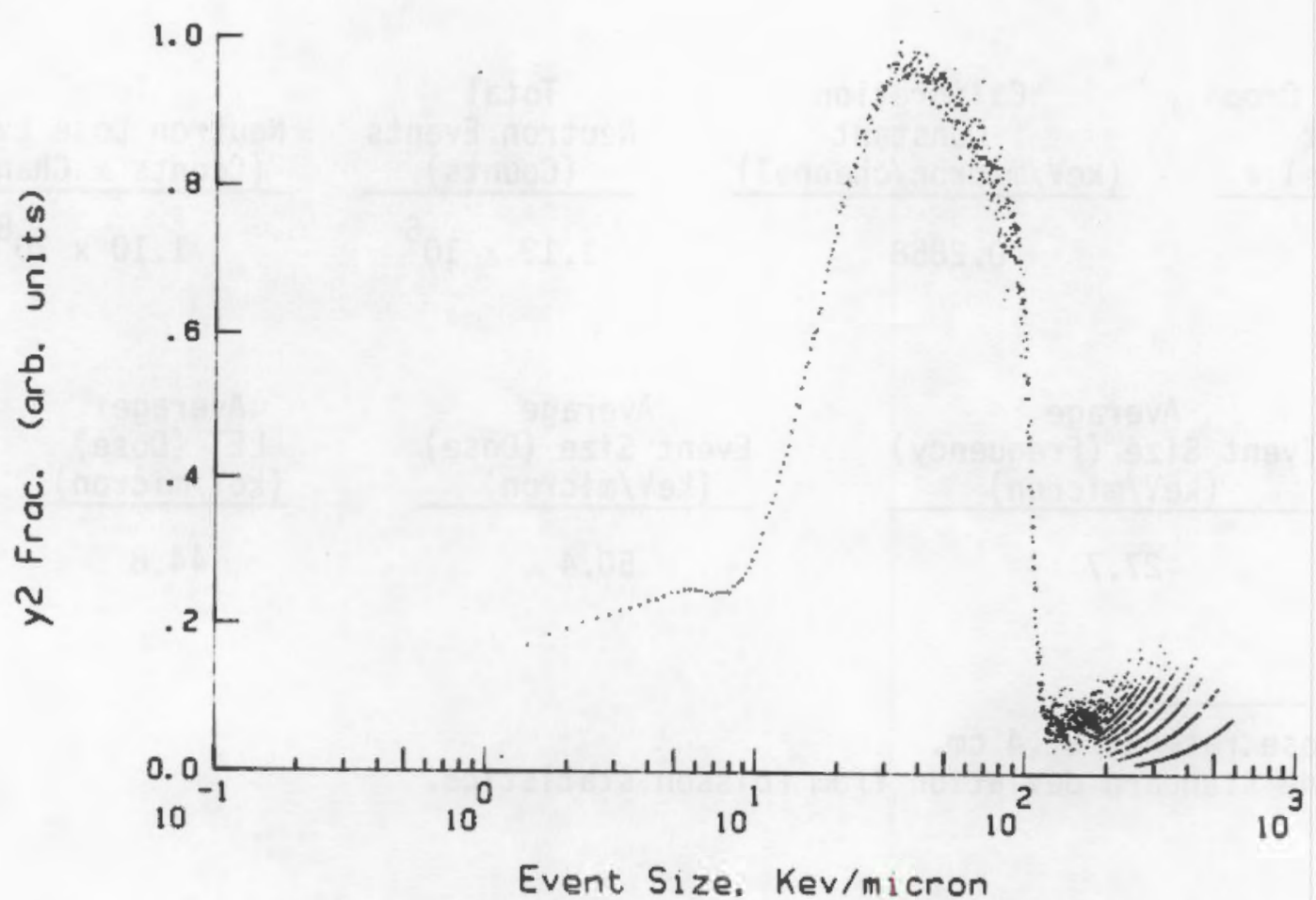

FIGURE A.2. $\quad Y^{2}$ Distribution for NBS Bare ${ }^{252} \mathrm{Cf}$ Neutron Measurement 
TABLE A.2. NBS Bare ${ }^{252} \mathrm{Cf}$ - Gamma Measurement

\begin{tabular}{|c|c|c|}
\hline Source \# & $\begin{array}{c}\text { Gamma }(a) \\
\text { DE Rate at } 1 \mathrm{~m} \\
\quad(m r e m / h r) \\
\end{array}$ & Da te \\
\hline NS-79 & 42 & $3 / 28 / 83$ \\
\hline
\end{tabular}

$\underline{\text { TEPC \# }}$

502

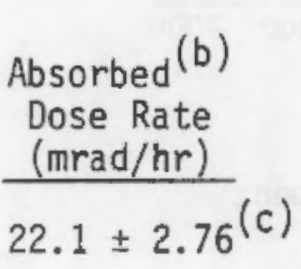

Site Equivalent Diameter (micrometers)

1.0

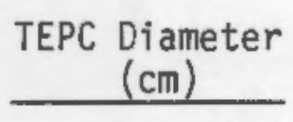

12.7
Live Time $(\mathrm{sec})$

3600

\section{Proton Drop \\ Point \\ Channel \#}

2926
Kellerer Approximation

\begin{tabular}{|c|c|}
\hline $\begin{array}{l}\text { Average } \\
\text { Qual ity } \\
\text { Factor } \\
\end{array}$ & $\begin{array}{c}\text { Dose Equivalent } \\
\text { Rate } \\
\text { (mrem/hr) }\end{array}$ \\
\hline 1.0 & 22 \\
\hline
\end{tabular}

Borak Approximation

\begin{tabular}{|c|c|}
\hline $\begin{array}{l}\text { Average } \\
\text { Quality } \\
\text { Factor } \\
\end{array}$ & $\begin{array}{c}\text { Dose Equivalent } \\
\text { Rate } \\
\text { (mrem/hr) }\end{array}$ \\
\hline 1.2 & 26 \\
\hline
\end{tabular}

Average

Event Size (Frequency) (keV/micron)

1.3
Calibration Constant (keV/micron/channel)

0.0345

$\frac{\begin{array}{c}\text { Total } \\ \text { Neutron Events } \\ \text { (Counts) }\end{array}}{9.18 \times 10^{6}}$

Average Event Size (Dose) (keV/micron)

2.2
Total Neutron Dose Events (Counts $\times$ Channel)

\footnotetext{
(a) From Stoddard 1971.

(b) Dose rate at $81.4 \mathrm{~cm}$.

(c) Dne standard deviation from Poisson statistics.
} 


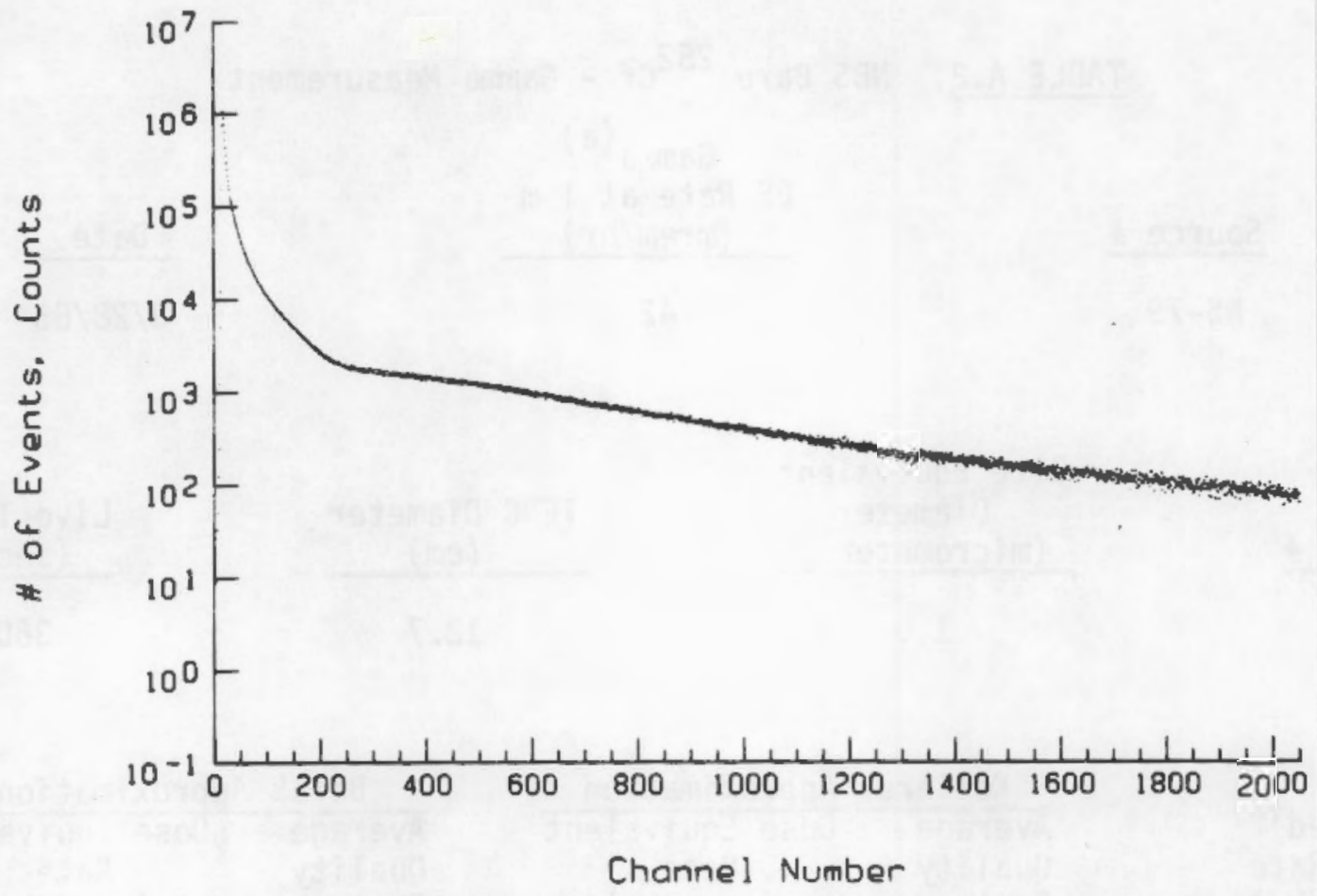

FIGURE A.3. Raw Data for NBS Bare ${ }^{252}$ Cf Gamma Measurement

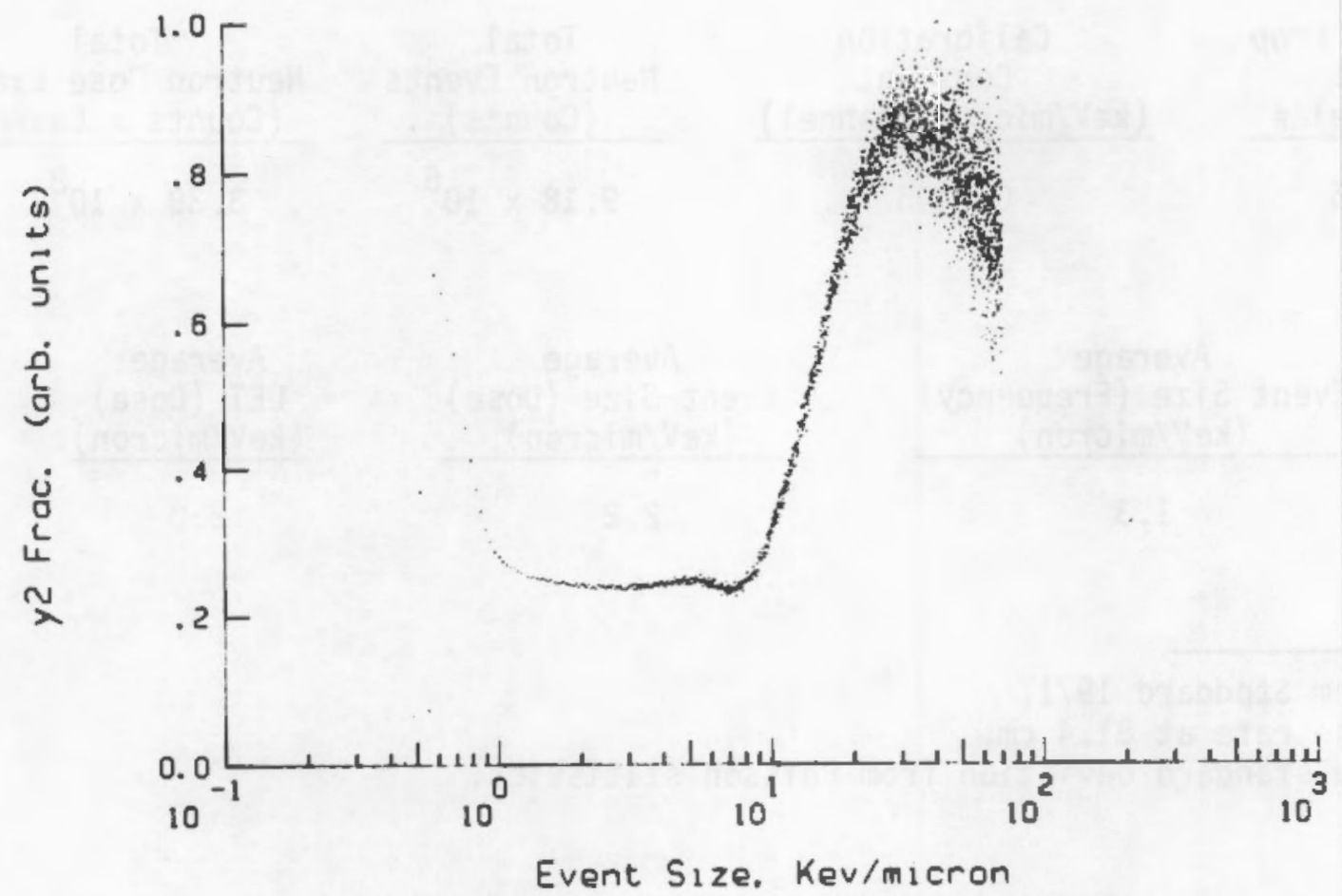

FIGURE A.4. $Y^{2}$ Distribution for NBS Bare ${ }^{252} C f$ Gamma Measurement 
TABLE A.3. NBS $\mathrm{D}_{2} 0$-Moderated ${ }^{252} \mathrm{Cf}$ - Neutron Measurement

\begin{tabular}{|c|c|c|c|}
\hline Source \# & $\begin{array}{c}\text { Emission Rate } \\
(\mathrm{n} / \mathrm{sec})\end{array}$ & $\begin{array}{l}\text { DE Rate at } 1 \mathrm{~m} \\
(\mathrm{mrem} / \mathrm{hr}) \\
\end{array}$ & Date \\
\hline NS-86 & $8.91 \times 10^{8}$ & 205 & $3 / 28 / 83$ \\
\hline TEPC \# & $\begin{array}{c}\text { Site Equivalent } \\
\text { Oiameter } \\
\text { (micrometers) } \\
\end{array}$ & $\begin{array}{l}\text { TEPC Diameter } \\
(\mathrm{cm}) \\
\end{array}$ & $\begin{array}{l}\text { Live Time } \\
\text { (sec) }\end{array}$ \\
\hline 502 & 1.0 & 12.7 & 6118 \\
\hline
\end{tabular}

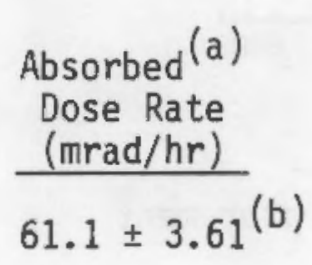

Kellerer Approximation

Borak Approximation

\begin{tabular}{|c|c|c|c|}
\hline $\begin{array}{l}\text { Average } \\
\text { Quality } \\
\text { Factor } \\
\end{array}$ & $\begin{array}{l}\text { Dose Equivalent } \\
\text { Rate } \\
\text { (mrem/hr) } \\
\end{array}$ & $\begin{array}{l}\text { Average } \\
\text { Quality } \\
\text { Factor } \\
\end{array}$ & $\begin{array}{c}\text { Dose Equivalent } \\
\text { Rate } \\
\text { (mrem/hr) } \\
\end{array}$ \\
\hline 9.2 & 565 & 10.4 & 637 \\
\hline
\end{tabular}

Proton Drop

Point

Calibration

Constant

Total

Total

Channel \#

(keV/micron/channel)

351

0.2875

Neutron Events

(Counts)

Neutron Oose Events

$1.77 \times 10^{6}$ (Counts $\times$ Channel)

Average

Event Size (Frequency) (keV/micron)

30.9
Average Event Size (Dose)
(keV/micron)

53.7

$1.90 \times 10^{8}$

Average LET (Oose) (keV/micron)

47.7

(a) Dose rate at $56.4 \mathrm{~cm}$.

(b) One standard deviation from Poisson statistics. 


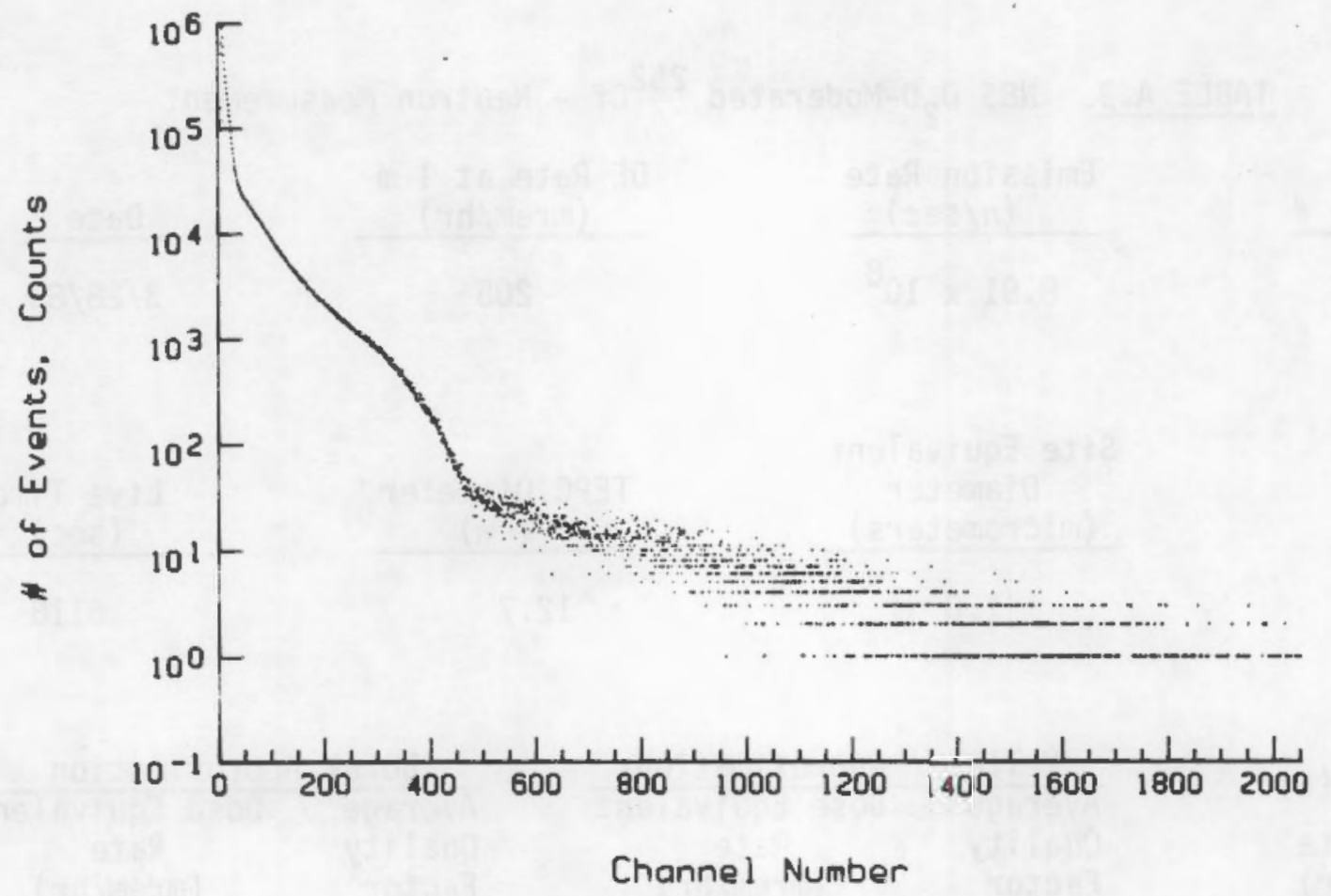

FIGURE A.5. Raw Data for NBS $\mathrm{D}_{2} \mathrm{O}$-Moderated ${ }^{252} \mathrm{Cf}$ Neutron Measurement

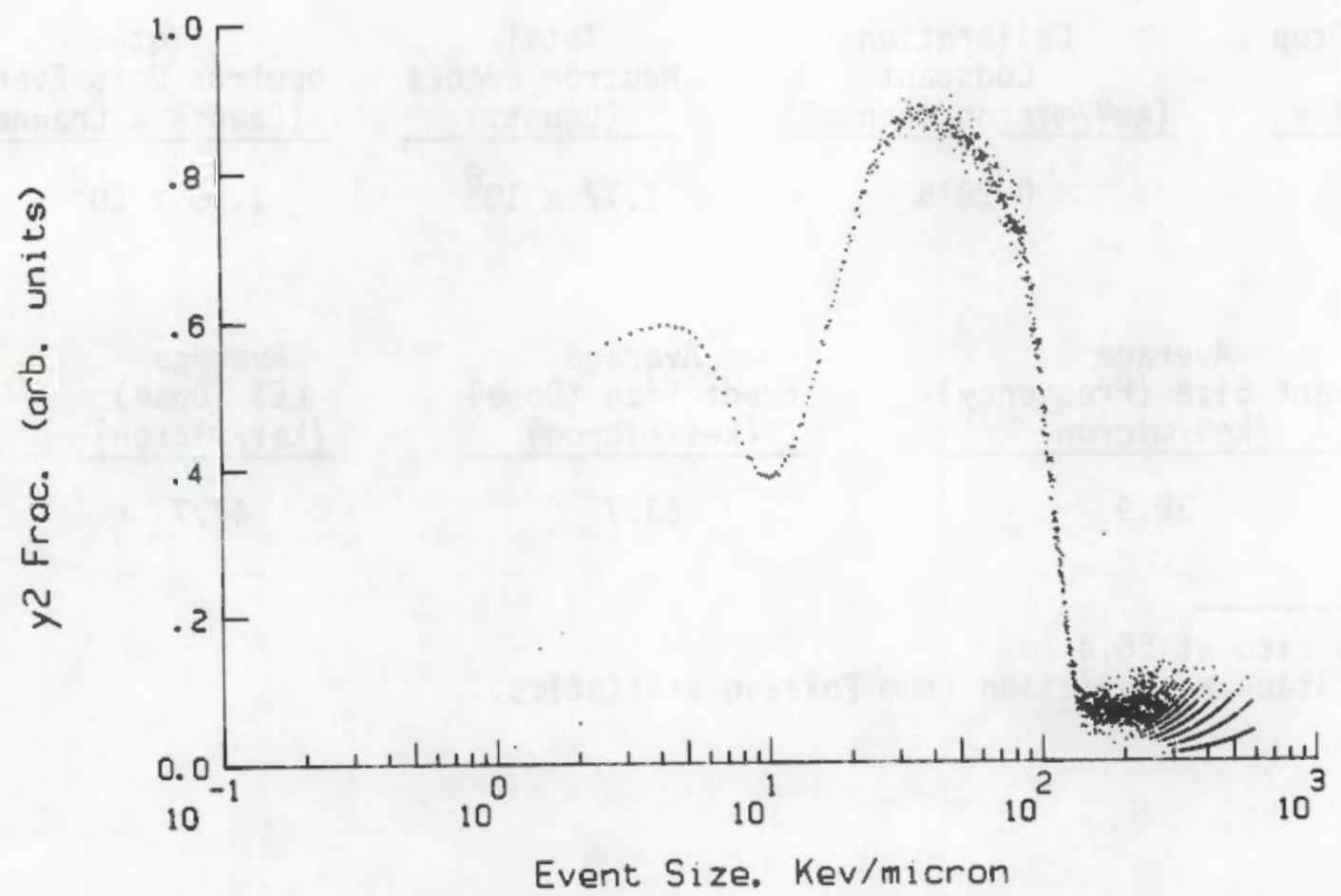

FIGURE A.6. $\quad Y^{2}$ Distribution for NBS $\mathrm{D}_{2} 0$-Moderated ${ }^{252} \mathrm{Cf}$ Neutron Measurement 
TABLE A.4. NBS $D_{2} 0$-Moderated ${ }^{252} \mathrm{Cf}$ - Gamma Measurement

Source \#

$\mathrm{DE}$ Rate at $1 \mathrm{~m}^{(\mathrm{a})}$

NS-86

(mrem/hr)

Date

116

$3 / 28 / 83$

$\begin{array}{cccc}\text { TEPC \# } & \begin{array}{c}\text { Site Equivalent } \\ \text { Diameter } \\ \text { (micrometers) }\end{array} & \frac{\begin{array}{c}\text { TEPC Diameter } \\ (\mathrm{cm})\end{array}}{12.7} & \frac{\begin{array}{c}\text { Live Time } \\ (\mathrm{sec})\end{array}}{602} \\ & 1.0 & & 6118\end{array}$

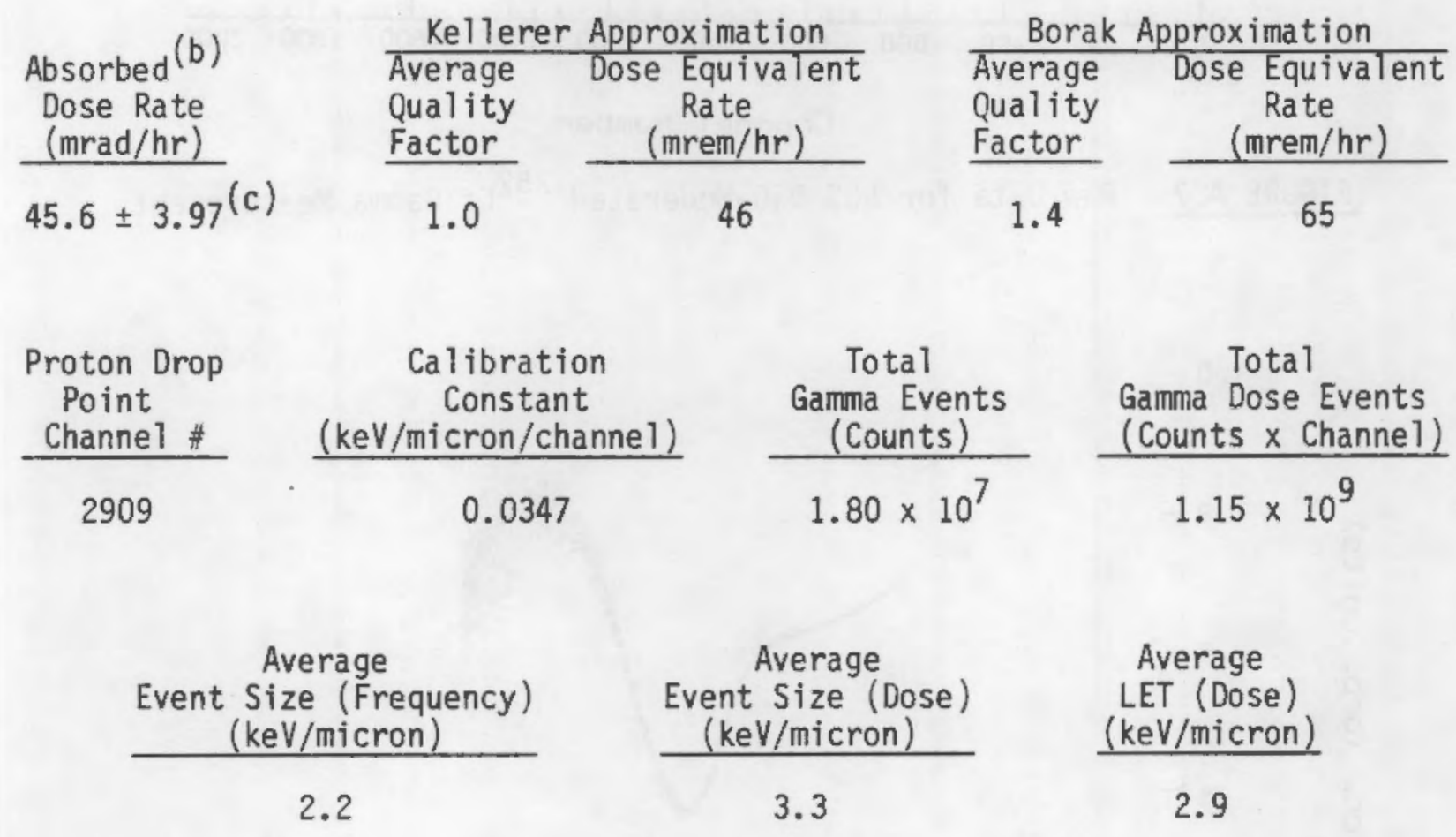

(a) From Stoddard 1971.

(b) Dose rate at $81.4 \mathrm{~cm}$.

(c) One standard deviation from Poisson statistics. 


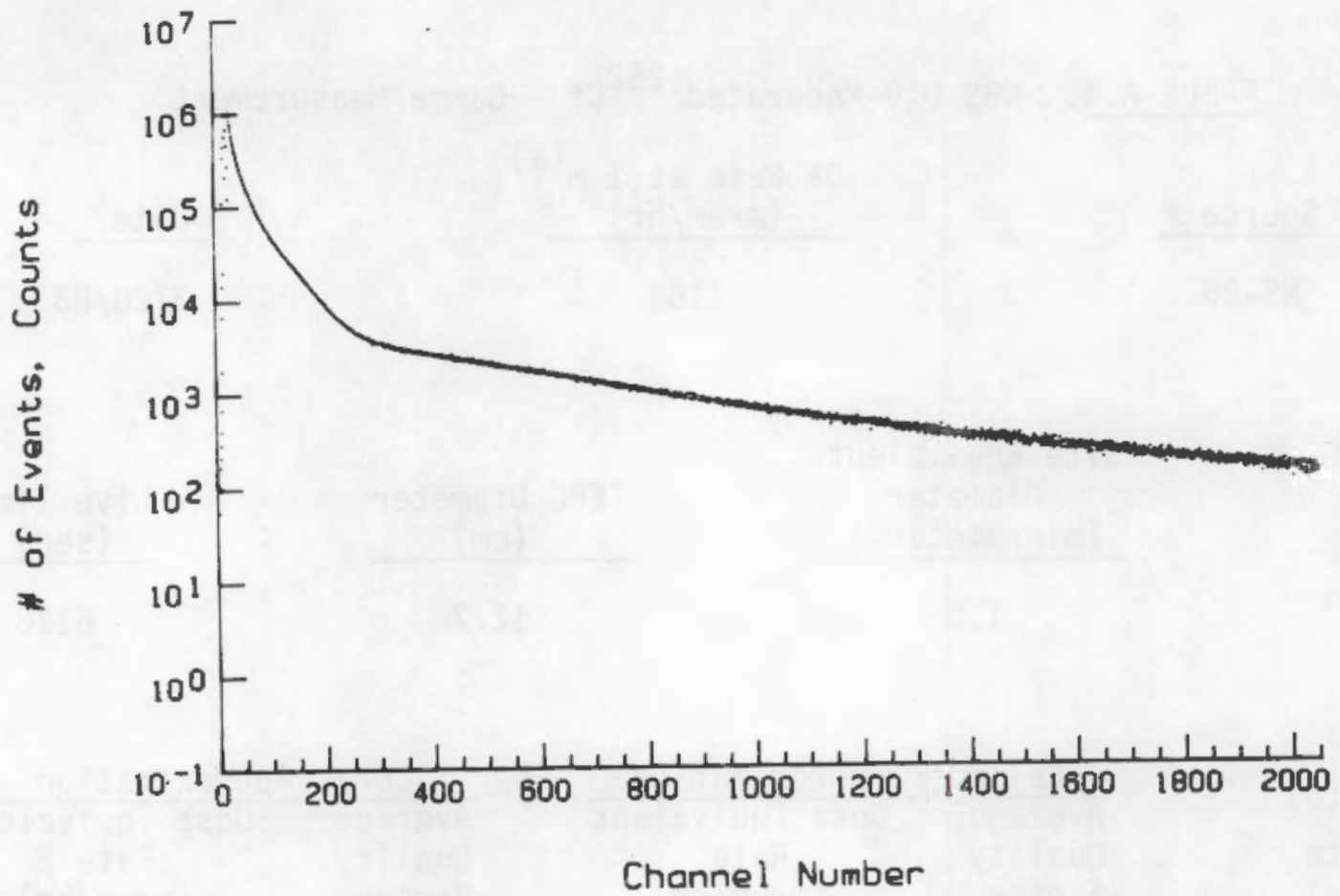

FIGURE A.7. Raw Data for NBS $\mathrm{D}_{2} 0$-Moderated ${ }^{252} \mathrm{Cf}$ Gamma Measurement

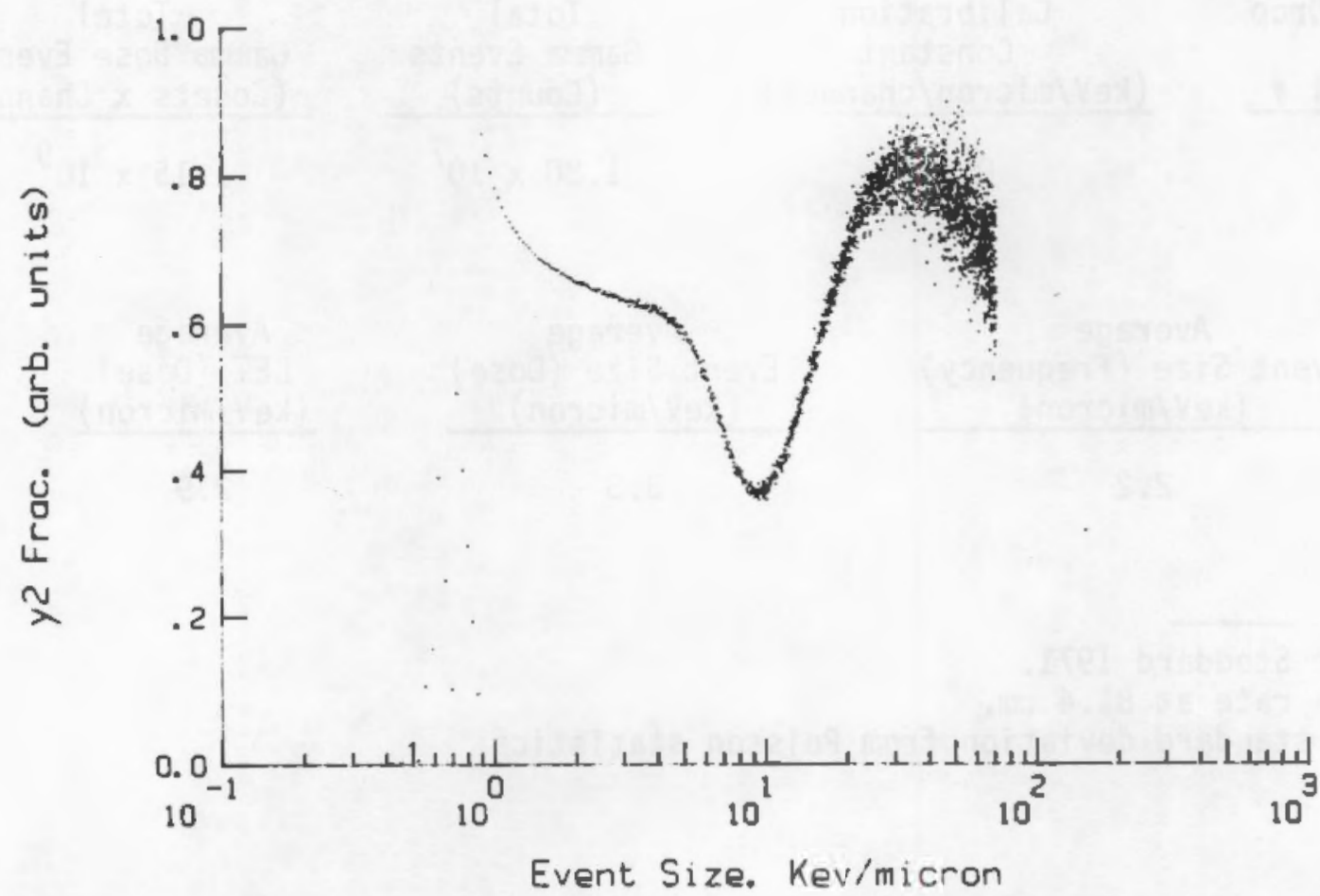

FIGURE A.8. $\quad \mathrm{Y}^{2}$ Distribution for NBS $\mathrm{D}_{2} 0$-Moderated ${ }^{252} \mathrm{Cf}$ Gamma Measurement 
IABLE A.5. PNL Cf-252 Neutron Measurement

Source \#

$\mathrm{CF}-3$

$\underline{\text { TEPC \# }}$

502
Emission Rate

$1.083 \times 10^{7}$
Reference

DE Rate

(mrem/hr)

43

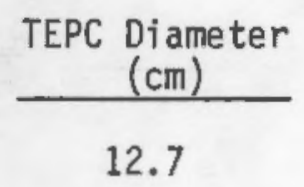

Date

$10 / 04 / 83$
Site Equivalent Diameter (micrometers)

2.0
Kellerer Approximation \begin{tabular}{cc}
$\begin{array}{c}\text { Average } \\
\text { Quality }\end{array}$ & $\begin{array}{c}\text { Dose Equivalent } \\
\text { Rate } \\
\text { (mrem/hr) }\end{array}$ \\
\hline Factor &
\end{tabular}

8.1

36
Borak Approximation Average Dose Equivalent Quality Rate Factor $(\mathrm{mrem} / \mathrm{hr})$

9.8

43
Live Time $(\mathrm{sec})$

18000

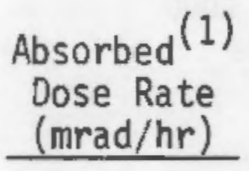

$4.40 \pm 0.19$

Proton Drop

Point Channel \#

667
Calibration Constant (keV/micron/channel)

0.1469
Total Neutron Events (Counts)

$4.23 \times 10^{5}$
Average

Event Size (Frequency) (keV/micron)

27.3
Average Event Size (Dose) (keV/micron)

45.4
Total Neutron Dose Events (Counts $\times$ Channel) $7.89 \times 10^{7}$

(1) One standard deviation from Poisson Statistics. 


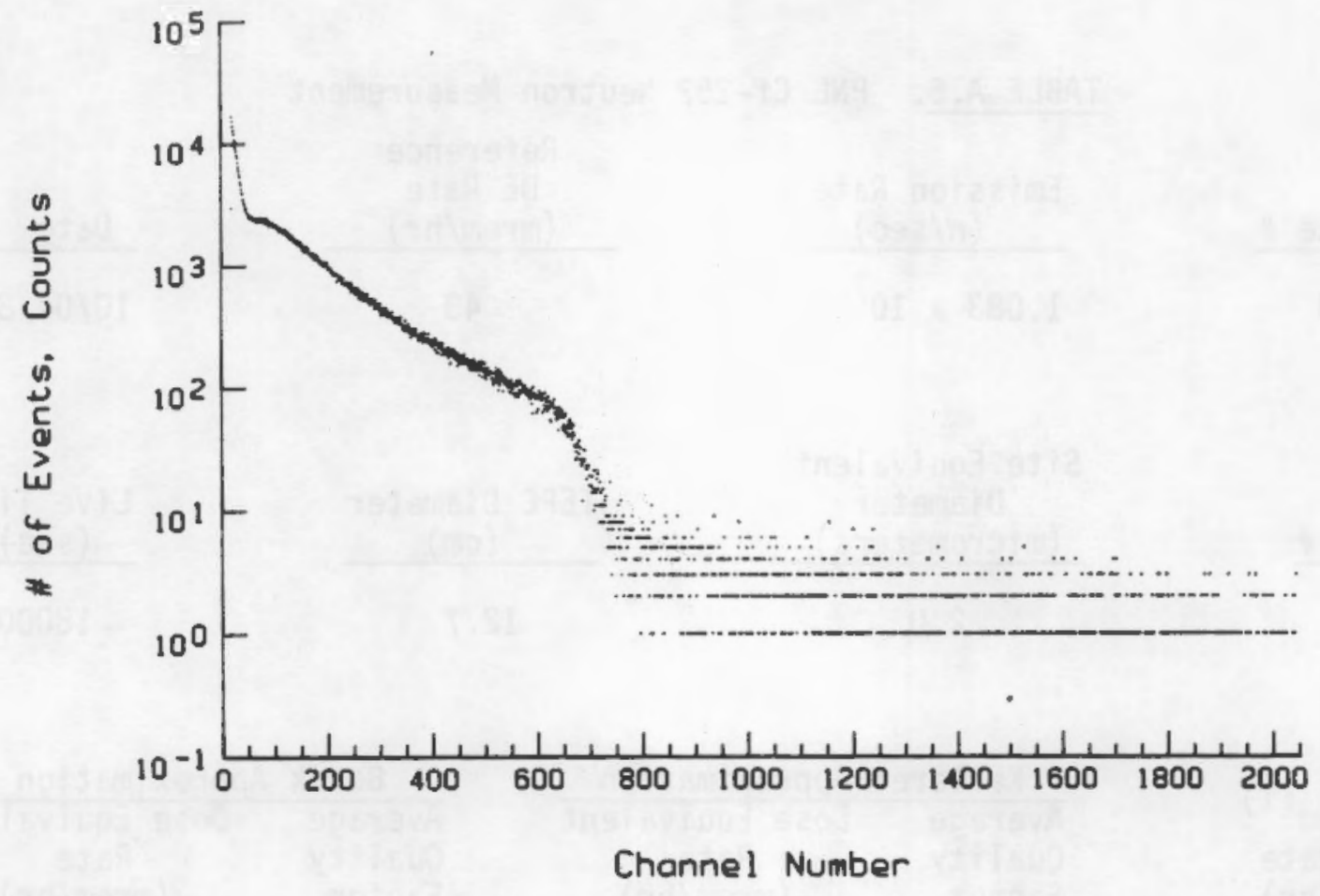

FIGURE A.9. Raw Data for PNL Bare ${ }^{252}$ Cf Neutron Measurement

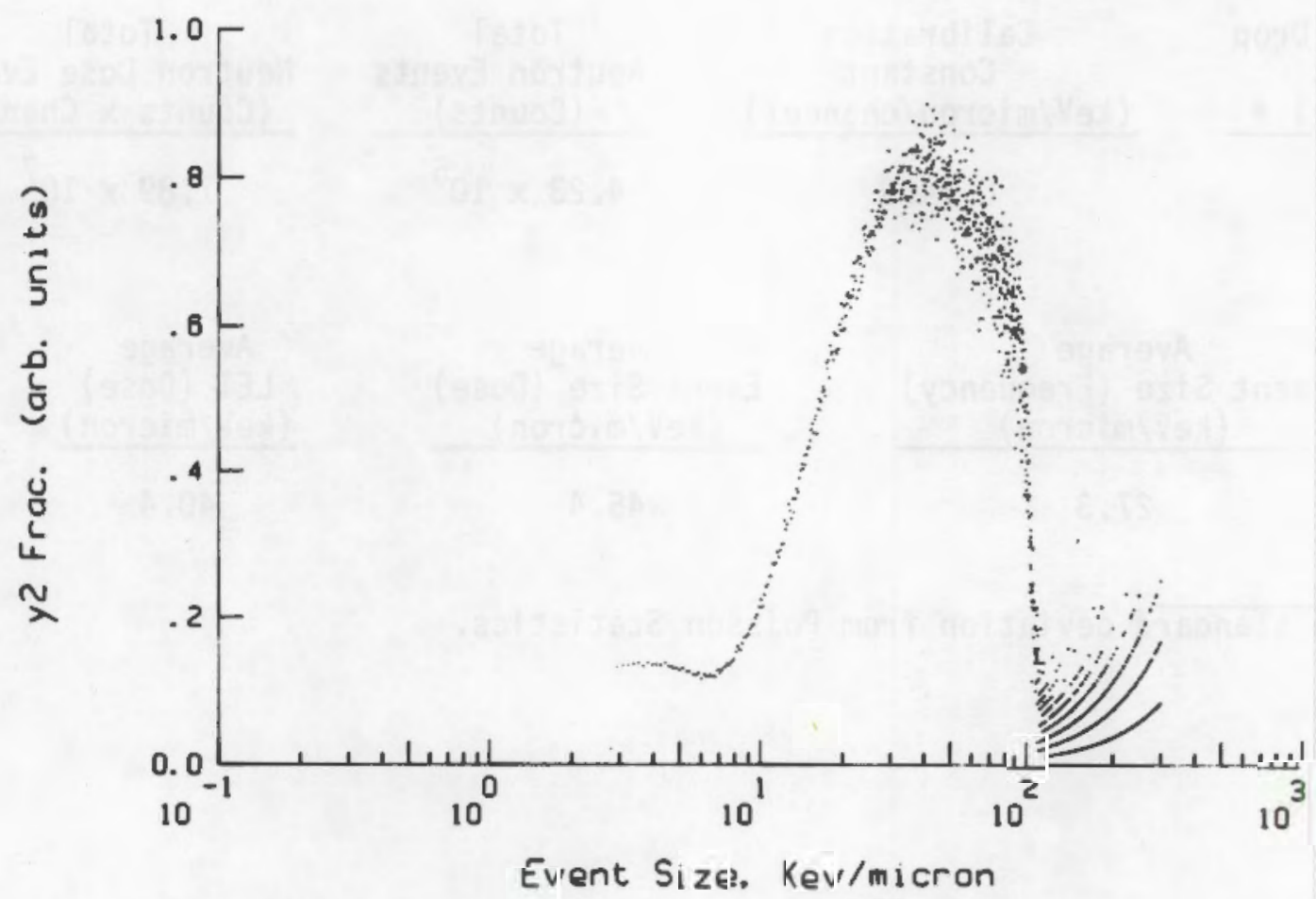

FIGURE A.10. $Y^{2}$ Distribution for PNL Bare ${ }^{252} \mathrm{Cf}$ Neutron Measurement 
TABLE A.6. PNL Cf-252 Gamma Measurement

Source \# $\quad \frac{\begin{array}{c}\text { Emission Rate } \\ (\mathrm{n} / \mathrm{sec})\end{array}}{1.083 \times 10^{7}} \quad \frac{\begin{array}{c}\text { Reference } \\ \text { DE Rate } \\ \text { (mrem/hr) }\end{array}}{3^{(1)}} \quad \frac{\text { Date }}{10 / 04 / 83}$

\begin{tabular}{|c|c|c|c|}
\hline TEPC \# & $\begin{array}{c}\text { Site Equivalent } \\
\text { Diameter } \\
\text { (micrometers) }\end{array}$ & $\begin{array}{c}\text { TEPC Diameter } \\
(\mathrm{cm})\end{array}$ & $\begin{array}{c}\text { Live Time } \\
(\mathrm{sec})\end{array}$ \\
\hline 502 & 2.0 & 12.7 & 18000 \\
\hline
\end{tabular}

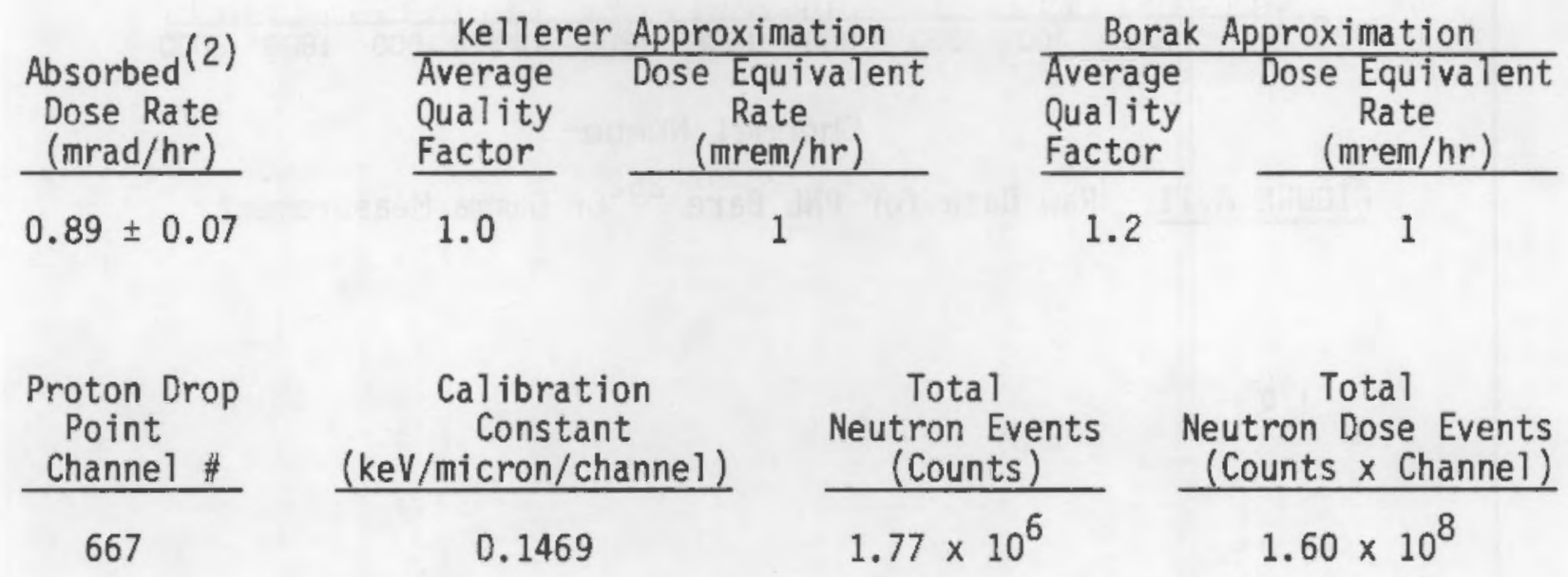

Average

Event Size (Frequency) (keV/micron)

\section{3}

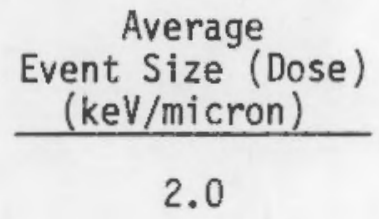

Average LET (Dose) $\underline{\text { (keV/micron) }}$

1.8

(1) From Stoddard, 1971.

(2) One standard deviation from Poisson Statistics. 


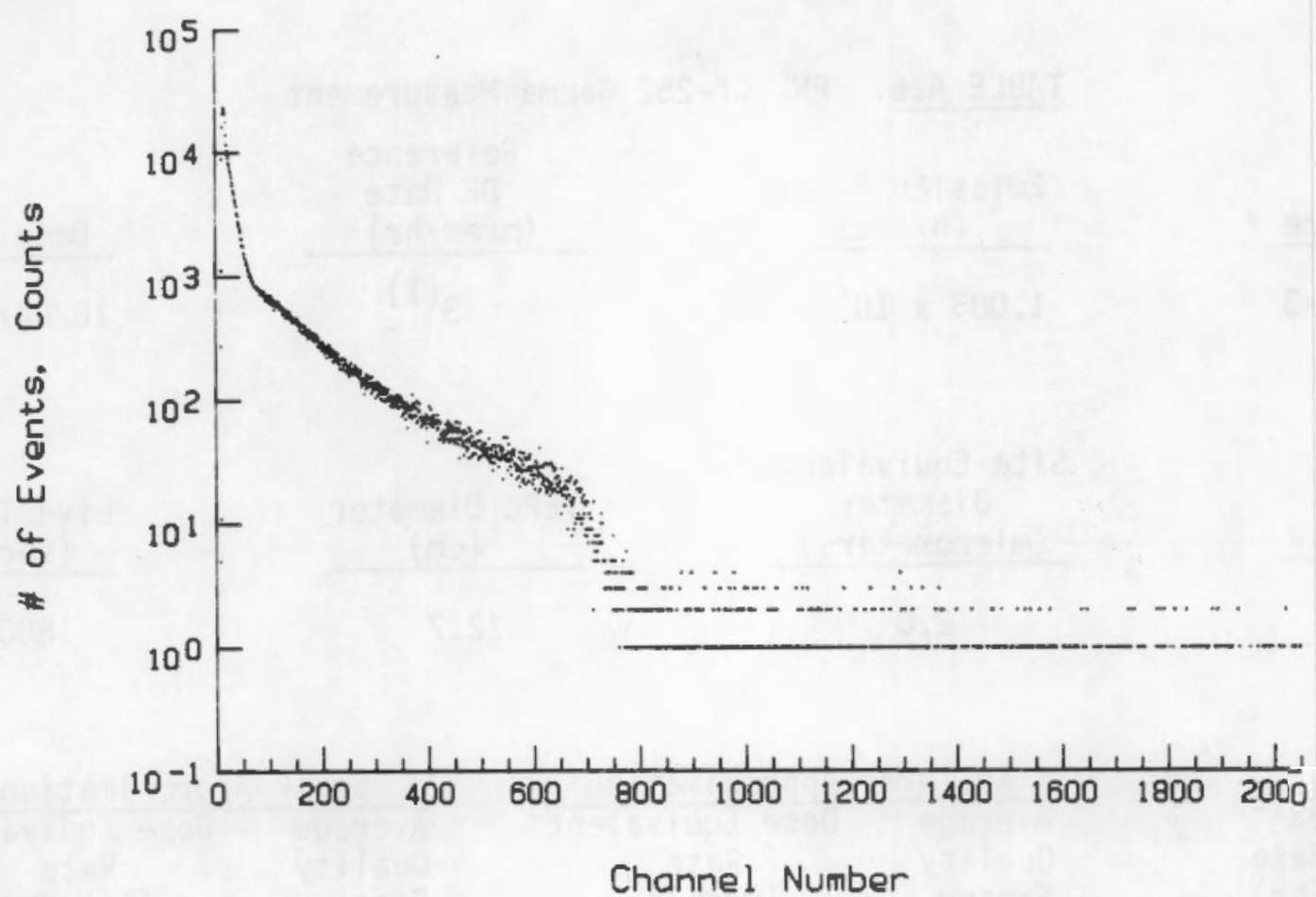

FIGURE A.11. Raw Data for PNL Bare ${ }^{252} \mathrm{Cf}$ Gamma Measurement

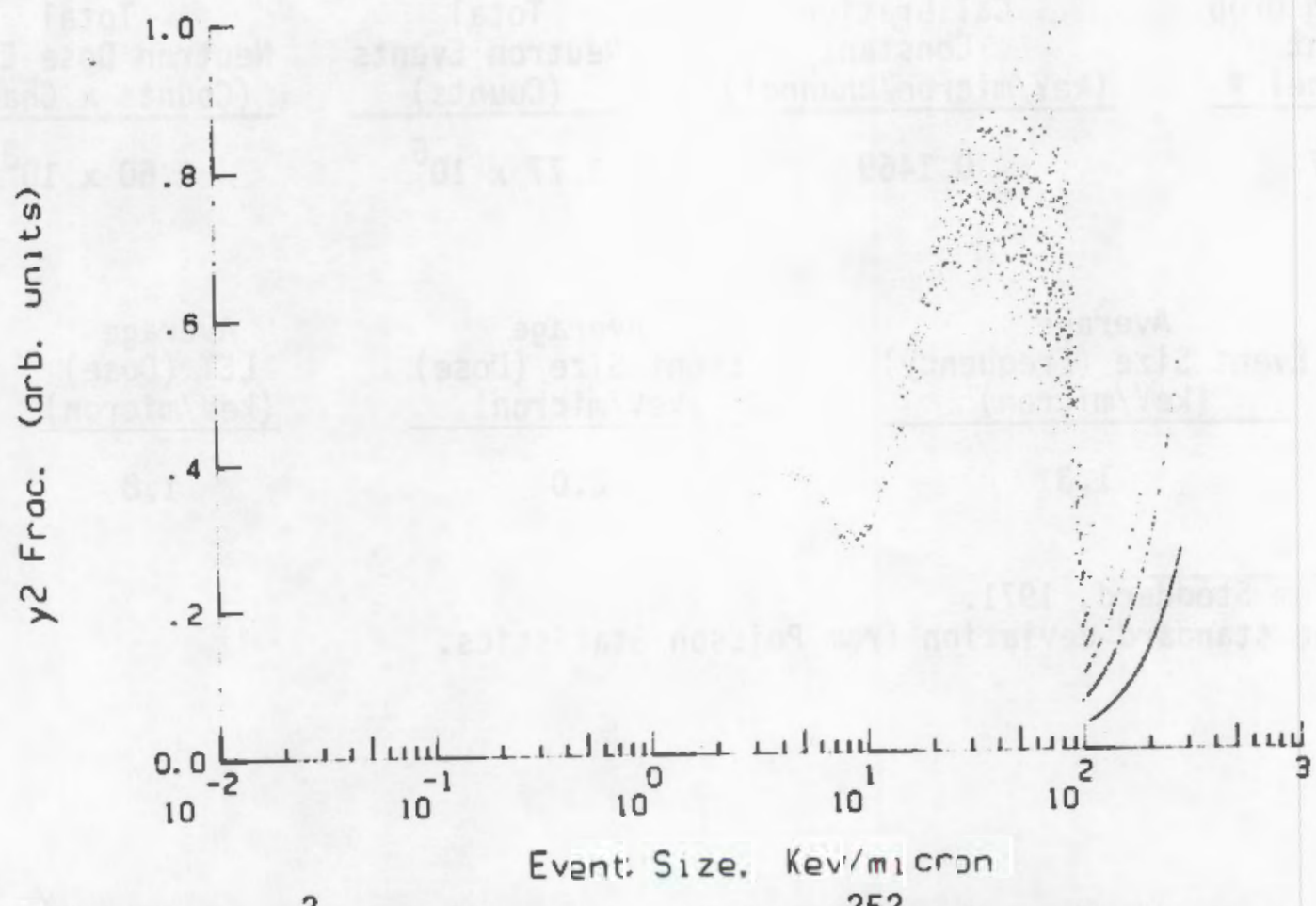

FIGURE A.12. $Y^{2}$ Distribution for PNL Bare ${ }^{252} \mathrm{Cf}$ Gamma Measurement 
TABLE A.7. PNL $\mathrm{D}_{2}$-Moderated ${ }^{252} \mathrm{Cf}$ - Neutron Measurement

\begin{tabular}{|c|c|c|c|}
\hline Source \# & $\begin{array}{c}\text { Emission Rate } \\
(\mathrm{n} / \mathrm{sec}) \\
\end{array}$ & $\begin{array}{c}\text { Neutron } \\
\text { DE Rate at } 1 \mathrm{~m} \\
\text { (mrem/hr) } \\
\end{array}$ & Date \\
\hline SR-Cf-249Z & $2.40 \times 10^{8}$ & 170 & $9 / 22 / 83$ \\
\hline TEPC \# & $\begin{array}{c}\text { Site Equivalent } \\
\text { Diameter } \\
\text { (micrometers) }\end{array}$ & $\begin{array}{c}\text { TEPC Diameter } \\
(\mathrm{cm}) \\
\end{array}$ & $\begin{array}{l}\text { Live Time } \\
\text { (sec) }\end{array}$ \\
\hline 183 & 1.0 & 5.7 & 5000 \\
\hline
\end{tabular}

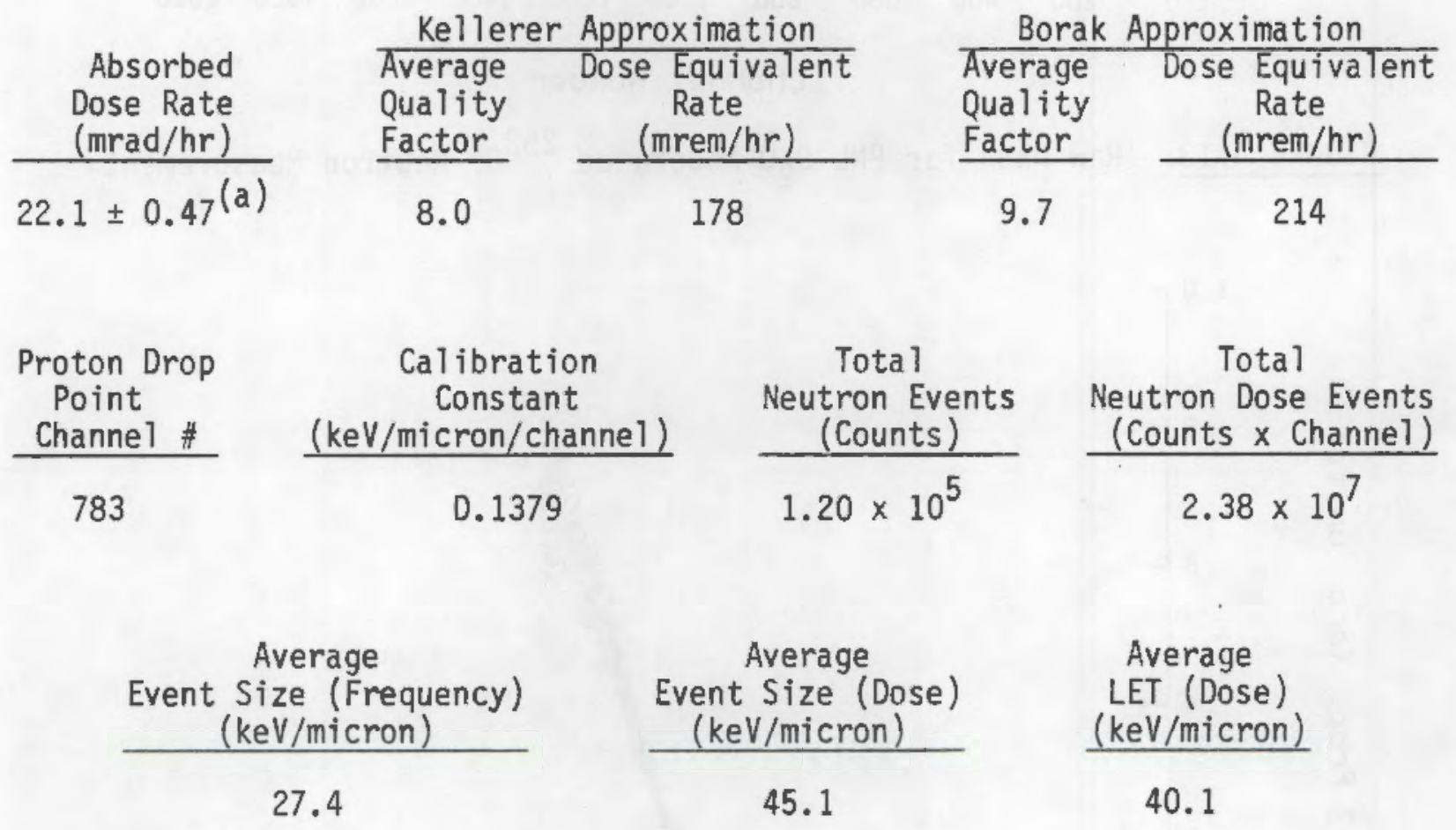

(a) One standard deviation from Poisson statistics. 


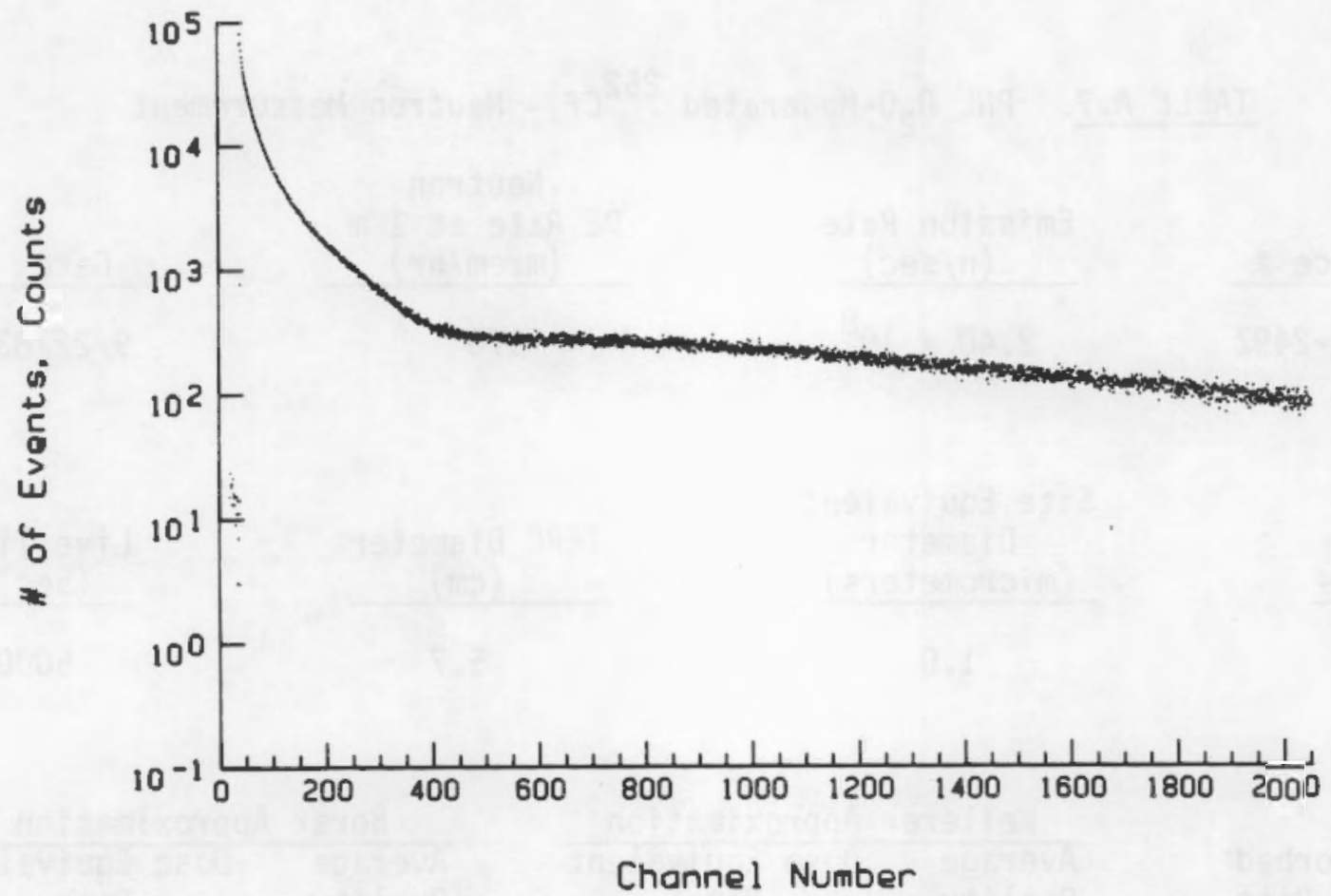

FIGURE A.13. Raw Data for PNL $\mathrm{D}_{2} 0$-Moderated ${ }^{252} \mathrm{Cf}$ Neutron Measurement

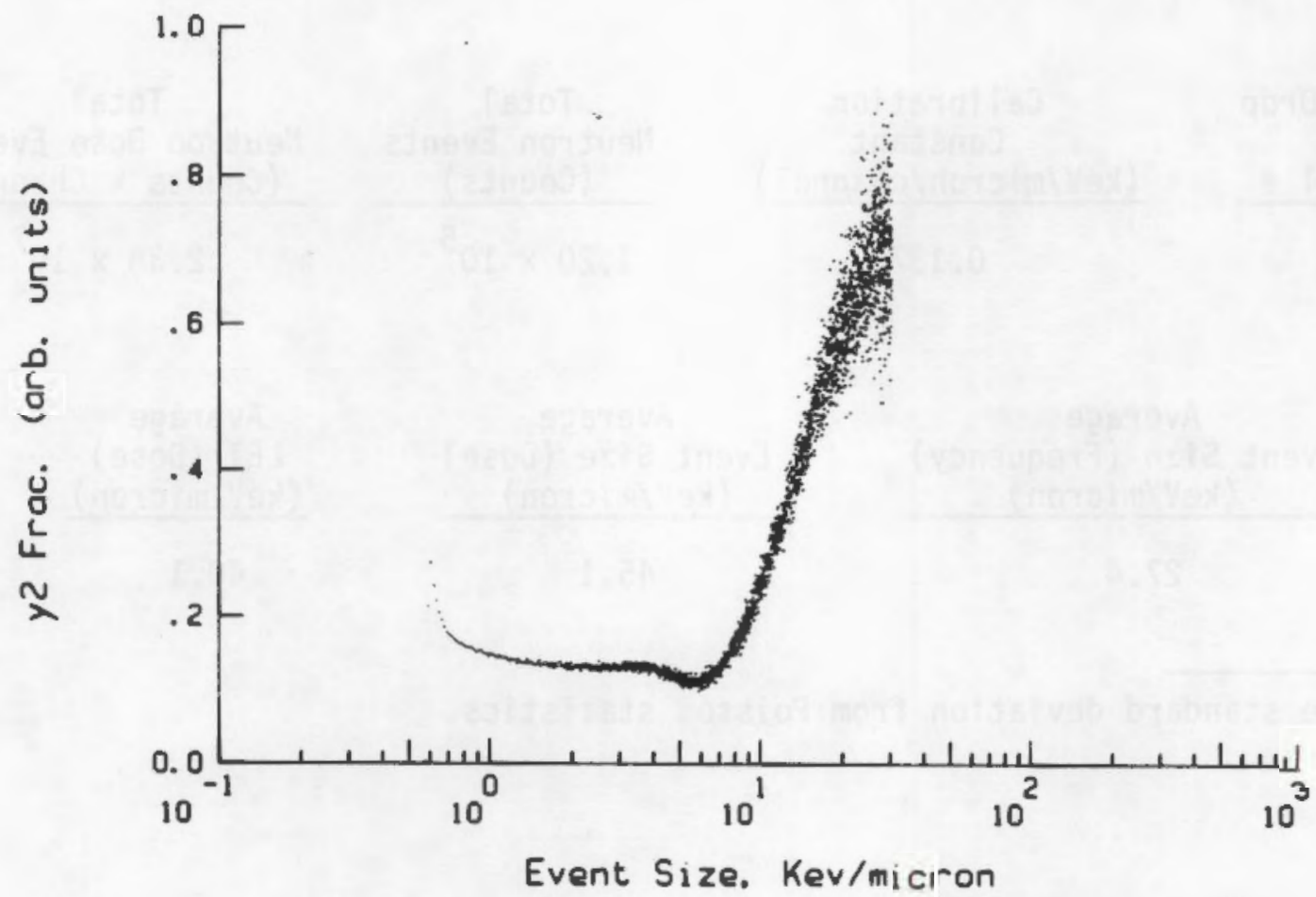

FIGURE A.14. $Y^{2}$ Distribution for PNL $\mathrm{D}_{2} 0$-Moderated ${ }^{252} \mathrm{Cf}$ Neutron Measurement 
TABLE A.8. PNL $D_{2} 0$-Moderated ${ }^{252} \mathrm{Cf}$ - Gamma Measurement

$\frac{\text { Source \# }}{\text { SR-CF-249Z }}$
DE Rate at $1 \mathrm{~m}$

$\frac{(\mathrm{mrem} / \mathrm{hr})}{{ }_{31}(\mathrm{a})}$

$31^{(a)}$
Date

$9 / 22 / 83$ $\underline{\text { TEPC \# }}$

183
Site Equivalent

Diameter (micrometers)

1.0
TEPC Diameter
$(\mathrm{cm})$

5.7
Live Time (sec)

5000

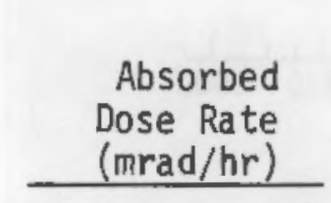

$23.9 \pm 1.19^{(b)}$
Kellerer Approximation

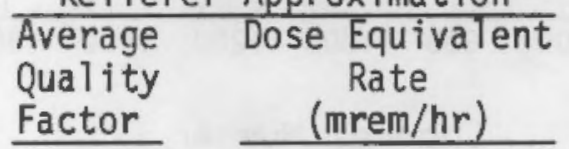

1.0

24

\begin{tabular}{|c|c|}
\hline Dorat & UII \\
\hline $\begin{array}{l}\text { Average } \\
\text { Quality } \\
\text { Factor }\end{array}$ & $\begin{array}{c}\text { Rate } \\
\text { (mrem/hr) }\end{array}$ \\
\hline
\end{tabular}

1.2

30

\section{Proton Drop \\ Point Channel \#}

14,251

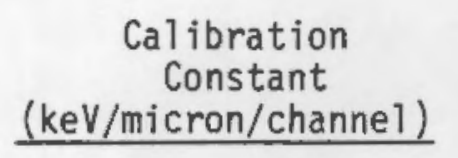

0.0071
Total Neutron Events (Counts)

$1.99 \times 10^{6}$
Total Neutron Dose Events (Counts x Channel)

$2.50 \times 10^{8}$
Average

Event Size (Frequency)

(keV/micron)

0.9

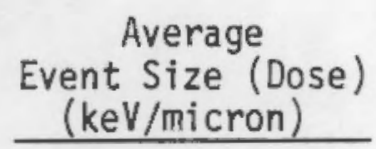

2.1
Average

LET (Dose)

$\underline{\text { (keV/micron) }}$

1.9

(a) From McDonald, et a l. 1983.

(b) One standard deviation from Poisson statistics. 


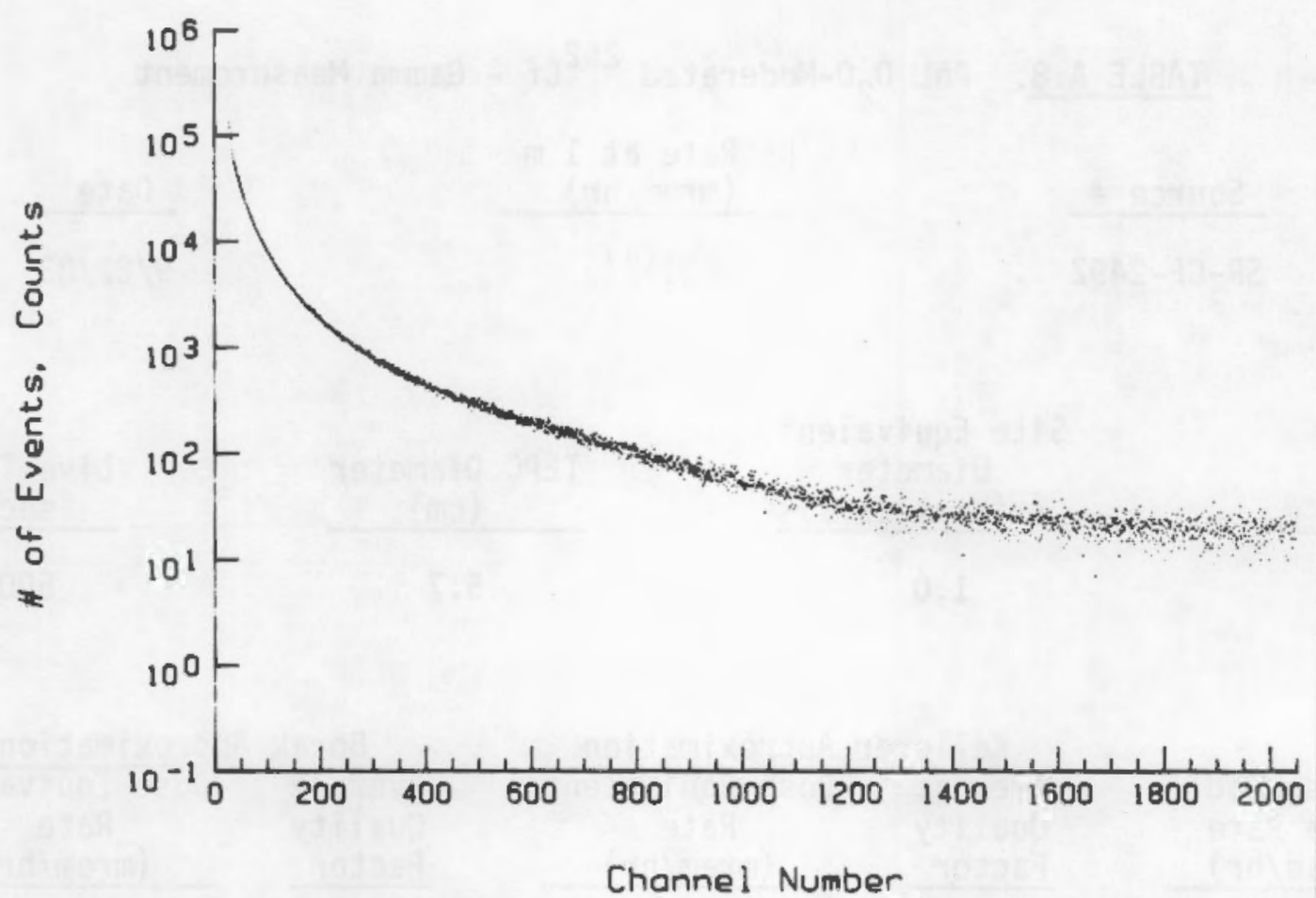

FIGURE A.15. Raw Data for PNL $\mathrm{D}_{2} 0$-Moderated ${ }^{252} \mathrm{Cf}$ Gamma Measurement
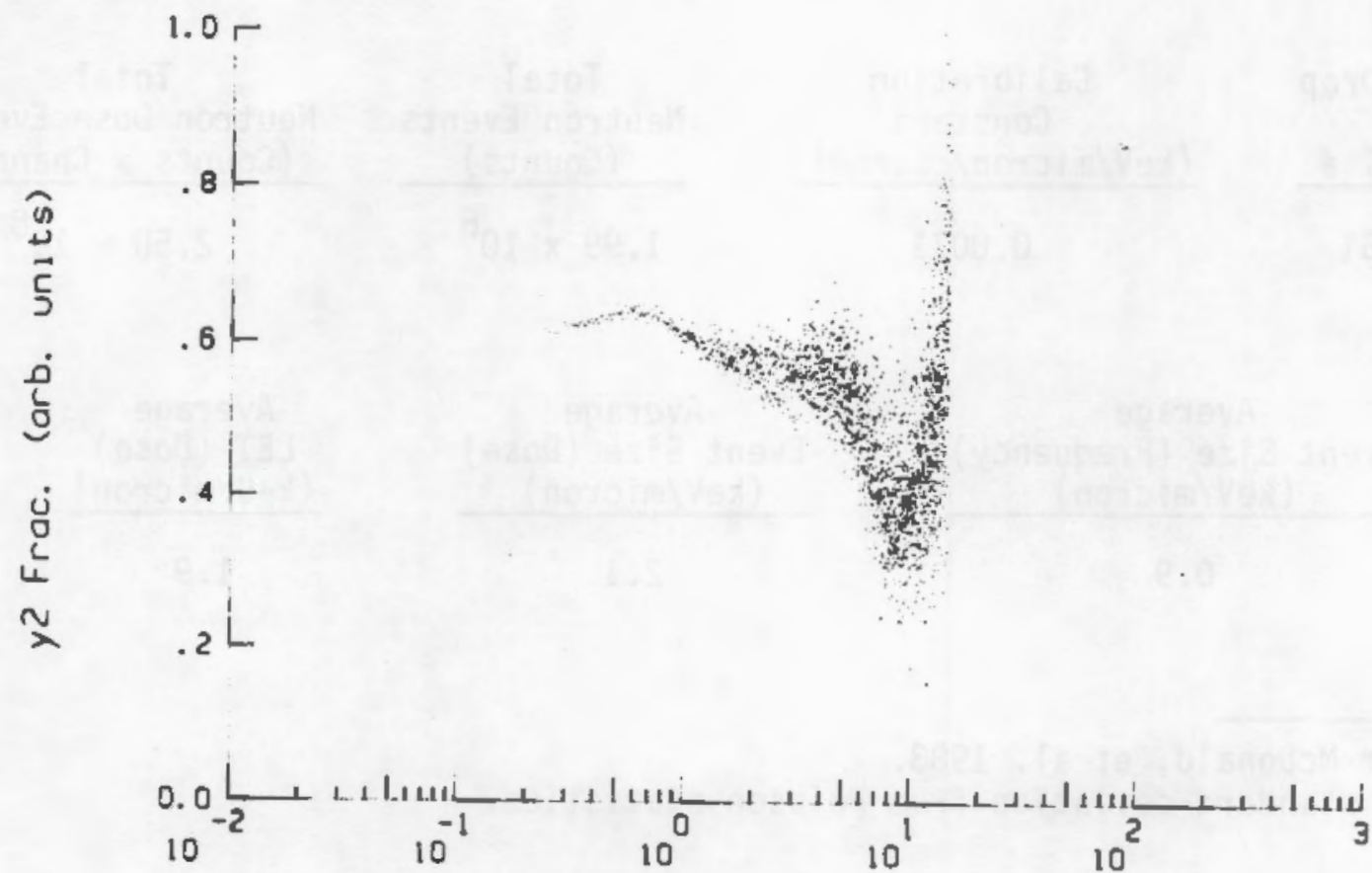

Event Size. Kev/micron

FIGURE A.16. $Y^{2}$ Distribution for PNL $D_{2} 0$-Moderated ${ }^{252} \mathrm{Cf}$ Gamma Measurement 
IABLE A.9. Site 1 (BWR) Neutron Measurement 1

Location $\quad \frac{\begin{array}{c}\text { SNOOPY } \\ \text { D/E Rate } \\ \text { (mrenthr) }\end{array}}{300} \quad \frac{\begin{array}{c}\text { Multisphere } \\ \text { DE Rate at } \\ \text { (mrem/hr) }\end{array}}{-} \quad \frac{\text { Date }}{12 / 29 / \text { B } 2}$
TEPC \# (micrometers)
502
2.0

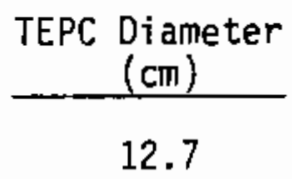

Live Time (sec)

1000

$\frac{\begin{array}{c}\text { Absorbed } \\ \text { Dose Rate } \\ \text { (mrad } / \mathrm{hr})\end{array}}{13.2 \pm 1.07^{(\mathrm{a})}}$

Kellerer Approximation

\begin{tabular}{lc}
$\begin{array}{l}\text { Average } \\
\text { Quality }\end{array}$ & Dose Equivalent \\
Rate \\
Factor & (mrem/hr) \\
\hline
\end{tabular}

8.7

115
Borak Approximation

\begin{tabular}{cc}
$\begin{array}{l}\text { Average } \\
\text { Quality }\end{array}$ & Dose Equivalent \\
Rate \\
Factor & (mrem/hr) \\
\hline
\end{tabular}

10.9

144

\begin{tabular}{|c|c|c|c|}
\hline $\begin{array}{l}\text { Proton Drop } \\
\text { Point } \\
\text { Channel \# }\end{array}$ & $\begin{array}{c}\text { Calibration } \\
\text { Constant } \\
(\mathrm{keV} / \mathrm{mi} \text { cron/channel })\end{array}$ & $\begin{array}{l}\text { Total } \\
\text { Neutron Events } \\
\text { (Counts) }\end{array}$ & $\begin{array}{l}\text { Total } \\
\text { Neutron Dose Events } \\
\text { (Counts } x \text { Channel) }\end{array}$ \\
\hline 199 & 0.4925 & $5.37 \times 10^{4}$ & $3.93 \times 10^{6}$ \\
\hline
\end{tabular}

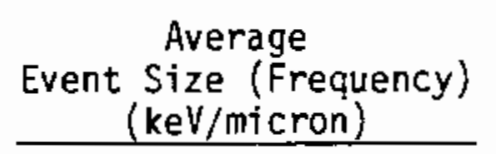

36.1

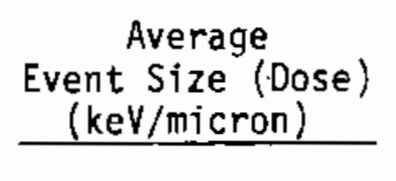

49.7
Average LET (Dose) (keV/micron)

44.2

(a) One standard deviation from Poisson statistics. 
TABLE A.10. Site 1 (BWR) Gamma Measurement 1

Location $11 \frac{\begin{array}{c}\text { Reference (a) } \\ \text { DE Rate at } \\ \text { (mrem/hr) }\end{array}}{1200} \quad \frac{\text { Date }}{12 / 29 / 82}$

$\frac{\text { TEPC \# }}{502}$

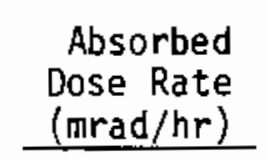

$29.6 \pm 10.6^{(b)}$

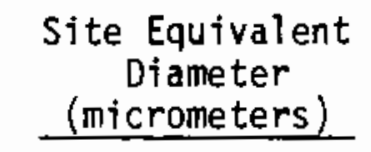

2.0

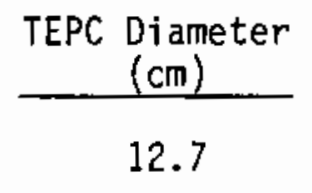

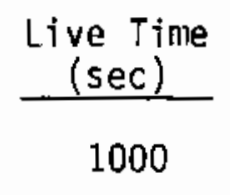

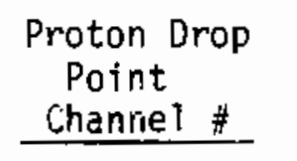

199

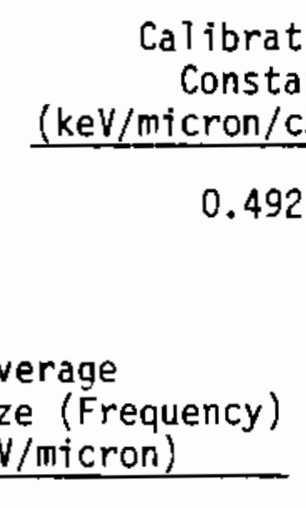

Kellerer Approximation

\begin{tabular}{lc}
$\begin{array}{l}\text { Average } \\
\text { Quality }\end{array}$ & $\begin{array}{c}\text { Dose Equivalent } \\
\text { Rate } \\
\text { (mrem } / \mathrm{hr} \text { ) }\end{array}$ \\
\hline
\end{tabular}

2.2

59

\begin{tabular}{lc}
\multicolumn{2}{c}{ Borak Approximation } \\
$\begin{array}{l}\text { Average } \\
\text { Quality }\end{array}$ & $\begin{array}{c}\text { Dose Equivalent } \\
\text { Rate } \\
\text { Ractor }\end{array}$ \\
$\frac{\text { (mrem/hr) }}{2.9}$ & 79
\end{tabular}

$\frac{\begin{array}{c}\text { Tota] } \\ \text { Neutron Events } \\ \text { (Counts) }\end{array}}{4.37 \times 10^{5}} \quad \frac{\begin{array}{c}\text { Total } \\ \text { Neutron Dose Events } \\ \text { (Counts } \times \text { Channel) }\end{array}}{8.00 \times 10^{6}}$

9.0

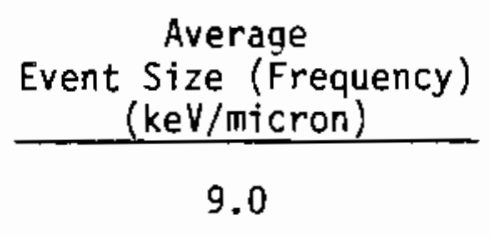

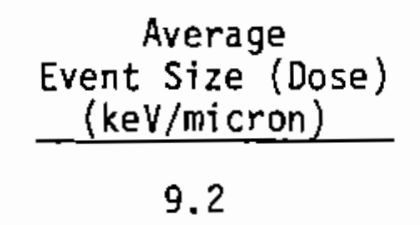

\author{
Average \\ LET (Dose) \\ (keV/micron) \\ 8.2
}

(a) Portable ion chamber.

(b) One standard deviation from Poisson statistics. 
TABLE A.11. Site 1 (BWR) Neutron Measurement 2

\begin{tabular}{|c|c|c|c|}
\hline Location & $\begin{array}{c}\text { SNOOPY } \\
\text { DE Rate } \\
\text { (mrem/hr) } \\
\end{array}$ & $\begin{array}{c}\text { Mu?tisphere } \\
\text { DE Rate } \\
\text { (mrem/hr) }\end{array}$ & Date \\
\hline 2 & $150-180$ & - & $12 / 29 / 82$ \\
\hline TEPC \# & $\begin{array}{c}\text { Site Equivalent } \\
\text { Diameter } \\
\text { (micrometers) } \\
\end{array}$ & $\begin{array}{c}\text { TEPC Diameter } \\
\text { (cm) } \\
\end{array}$ & $\begin{array}{l}\text { Live Time } \\
(\mathrm{sec})\end{array}$ \\
\hline 502 & 2.0 & 12.7 & $100 \mathrm{D}$ \\
\hline
\end{tabular}

$\frac{\begin{array}{c}\text { Absorbed } \\ \text { Dose Rate } \\ \text { (mrad/hr) }\end{array}}{6.48 \pm 0.60}(\mathrm{a})$

Kellerer Approximation

\begin{tabular}{cc}
$\begin{array}{c}\text { Average } \\
\text { Quality }\end{array}$ & $\begin{array}{c}\text { Dose Equivalent } \\
\text { Rate } \\
\text { (mrem/hr) }\end{array}$ \\
\hline
\end{tabular}

8.4

542
Borak Approximation

\begin{tabular}{ll}
$\begin{array}{l}\text { Average } \\
\text { Ouality } \\
\text { Factor }\end{array}$ & $\begin{array}{c}\text { Dose Equivalent } \\
\text { Rate } \\
\text { (mrem/hr) }\end{array}$ \\
\hline 10.6 & 690
\end{tabular}

\section{Proton Drop \\ Point \\ Channel \#}

162

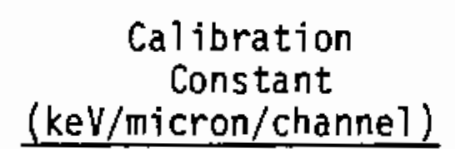

0.6049
Tota 7 Neutron Events (Counts)

$2.71 \times 10^{4}$
Total Neutron Dose Events (Counts $\times$ Channel)

$$
1.57 \times 10^{6}
$$

Average
Event Size (Frequency)
(keV/micron)

35.1

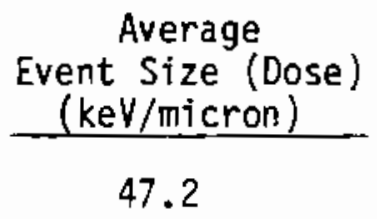

47.2
Average LET (Dose) ( $\mathrm{keV} / \mathrm{micron})$

42.0

(a) One standard deviation from Poisson statistics. 
TABLE A.12. Site 1 (BWR) Gamma Measurement 2

Location $2 \frac{\begin{array}{l}\text { Reference }(a) \\ \text { DE Rate at in } \\ \text { (mrem/hr) }\end{array}}{1200} \quad \frac{\text { Date }}{12 / 29 / 82}$

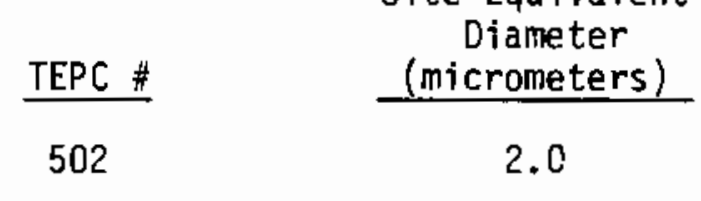
Site Equivalent
Diameter

2.0

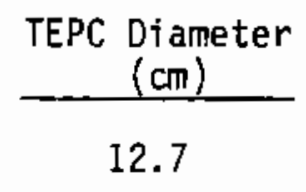

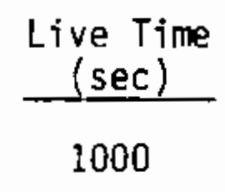

Live Time

1000

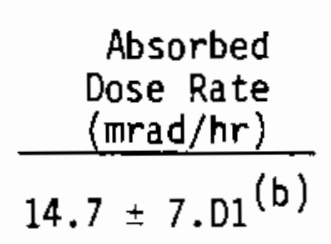

\begin{tabular}{l} 
Proton Drop \\
Point \\
Channel \# \\
\hline
\end{tabular}

162 $\frac{\text { Kellerer Approximation }}{\text { Average Dose Equivalen }}$

\begin{tabular}{lc}
$\begin{array}{l}\text { Average } \\
\text { Quality }\end{array}$ & $\begin{array}{c}\text { Dose Equivalent } \\
\text { Rate } \\
\text { Factor }\end{array}$ \\
\hline
\end{tabular}

2.4

36

\begin{tabular}{|c|c|}
\hline \multicolumn{2}{|c|}{ Borak Approximation } \\
\hline $\begin{array}{l}\text { Average } \\
\text { Quality } \\
\text { Factor }\end{array}$ & $\begin{array}{c}\text { Dose Equivalent } \\
\text { Rate } \\
\text { (mrem/hr) }\end{array}$ \\
\hline 3.3 & 4.8 \\
\hline
\end{tabular}

$\frac{\begin{array}{c}\text { Calibration } \\ \text { Constant } \\ \text { (kev/micron/channel) }\end{array}}{0.6049} \quad \frac{\begin{array}{c}\text { Total } \\ \text { Neutron Events } \\ \text { (Counts) }\end{array}}{2.04 \times 10^{5}} \frac{\begin{array}{c}\text { Tota } \\ \text { Neutron Dose Events } \\ \text { (Counts } \times \text { Channe1) }\end{array}}{3.55 \times 10^{6}}$

Average

Event Size (Frequency) ( $\mathrm{keV} / \mathrm{micron}$ )

Average Event Size (Dose) (keV/micron)

10.6

\author{
Average \\ LET (Dose) \\ (keV/micron)
}

10.5

9.4

(a) Portable ion chamber.

(b) One standard deviation from Poisson statistics. 
TABLE A.13. Site I (BWR) Neutron Measurement 3

Location $\quad \frac{\begin{array}{c}\text { SNOOPY } \\ \text { DE Rate } \\ (\mathrm{mrem} / \mathrm{hr})\end{array}}{2500} \quad \frac{\begin{array}{c}\text { Mu?tisphere } \\ \text { DE Rate } \\ (\mathrm{mrem} / \mathrm{hr})\end{array}}{3} \quad \frac{-}{\text { Date }}$

Site Equivalent
Diameter
(micrometers)

0.5

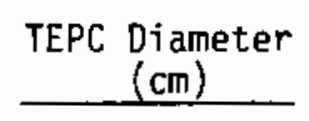

5.7
Live Time (sec)

1500 $\begin{gathered}\text { Absorbed } \\ \text { Dose Rate } \\ \text { (mrad/hr) }\end{gathered}$
$136.5 \pm 27.1^{(a)}$
Kelierer Approximation

Average Dose Equivalent

Quality

Factor

9.1 Rate (mrem/hr)

1240
Borak Approximation Average Dose Equivalent Quality Rate Factor (mrem/hr)

10.8

1480

\section{Proton Drop \\ Point \\ Channel \#}

78

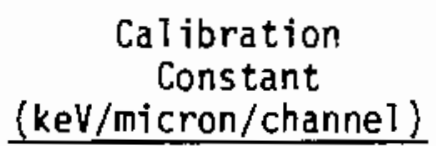

1.323
Tota 1 Neutron Events (Counts)

$1.73 \times 10^{5}$
Total Neutron Dose Events (Counts $x$ Channel)

$4.59 \times 10^{6}$
Average

Event Size (Frequency)

(keV/micron)

35.2

\author{
Average \\ Event Size (Dose) \\ (keV/micron)
}

52.3
Average LET (Dose) (keV/micron)

46.5

(a) One standard deviation from Poisson statistics. 
TABLE A.14. Site Ganma Measurement 3

Location $3 \quad \frac{\begin{array}{c}\text { Reference (a) } \\ \text { DEate at 1 m } \\ \text { (mrem/hr) }\end{array}}{1200} \quad \frac{\text { Date }}{12 / 29 / 82}$

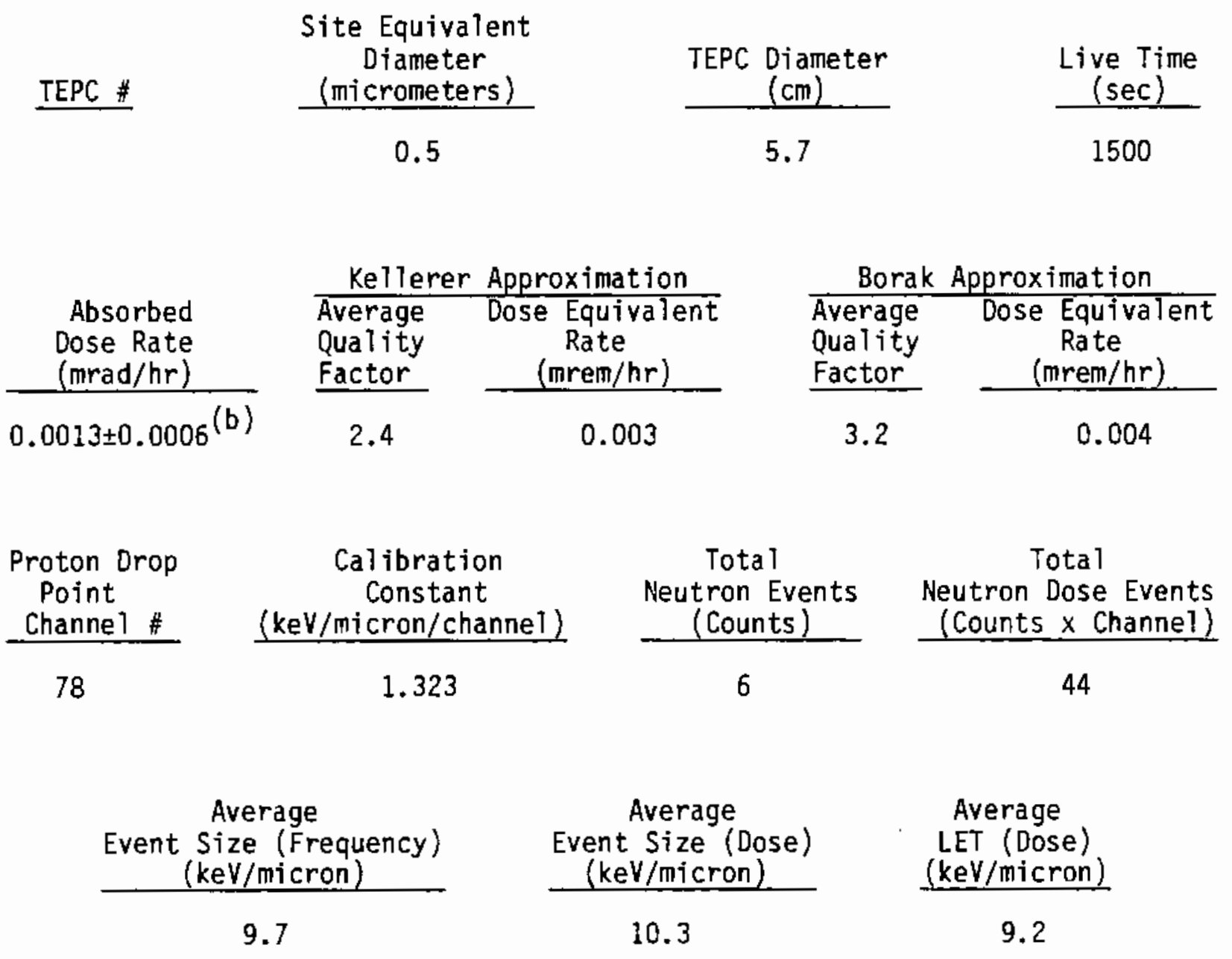

\footnotetext{
(a) Portable ion chamber.

(b) One standard deviation from Poisson statistics.
} 
TABLE A.15. Site 1 (BWR) Neutron Measurement 4

\begin{tabular}{|c|c|c|c|}
\hline Location & $\begin{array}{l}\text { SNOOPY } \\
\text { DE Rate } \\
\text { (mrem/hr) }\end{array}$ & $\begin{array}{c}\text { Multisphere } \\
\text { DE Rate } \\
\text { (mrem/hr) }\end{array}$ & Oate \\
\hline 4 & 330 & - & $12 / 29 / 82$ \\
\hline TEPC \# & $\begin{array}{c}\text { Site Equivalent } \\
\text { Diameter } \\
\text { (micrometers) } \\
\end{array}$ & $\begin{array}{l}\text { TEPC Diameter } \\
(\mathrm{cm}) \\
\end{array}$ & $\begin{array}{l}\text { Live Time } \\
\text { (sec) }\end{array}$ \\
\hline 502 & 2.0 & 12.7 & 1000 \\
\hline
\end{tabular}

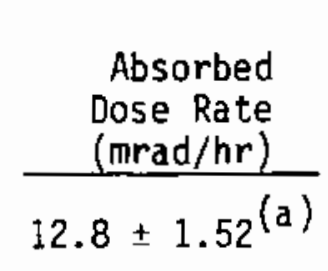

\begin{tabular}{|c|c|}
\hline Keller & Approximation \\
\hline $\begin{array}{l}\text { Average } \\
\text { Quality } \\
\text { Factor }\end{array}$ & $\begin{array}{l}\text { Dose Equivalent } \\
\text { Rate } \\
\text { (mrem } / \mathrm{hr} \text { ) }\end{array}$ \\
\hline 8.5 & 109 \\
\hline
\end{tabular}

Point

Channe? \#

123

\author{
Calibration \\ Constant \\ (keV/micron/channel)
}

0.7967

\begin{tabular}{l} 
Tota 1 \\
$\begin{array}{c}\text { Neutron Events } \\
\text { (Counts) }\end{array}$ \\
\hline
\end{tabular}

$5.70 \times 10^{4}$
Borak Approximation

$\begin{array}{lc}\begin{array}{l}\text { Average } \\ \text { Quaiity }\end{array} & \begin{array}{c}\text { Dose Equivalent } \\ \text { Rate } \\ \text { Factor }\end{array} \\ \text { (mrem } / \mathrm{hr} \text { ) }\end{array}$

10.6

136

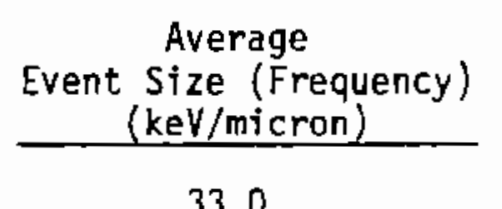

33.0

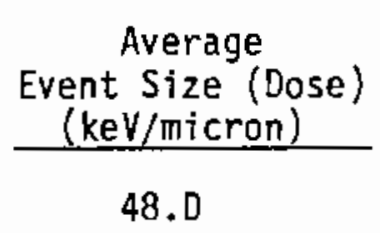

48. D
Tota 1

Neutron Dose Events (Counts $\times$ Channel)

$2.36 \times 10^{6}$

(a) One standard deviation from Poisson statistics. 
TABLE A.16. Site 1 (BWR) Gamma Measurement 4

Location $\quad \frac{\begin{array}{c}\text { Reference } \\ \text { DE Rate } \\ \text { (mrem/hr) }\end{array}}{1200} \quad \frac{\text { Date }}{12 / 29 / 82}$

$\underline{\text { TEPC \# }}$

502
Site Equivalent

(micrometers)

2.0
TEPC Djameter

$(\mathrm{cm})$

12.7
Live Time

(sec)

1000 \begin{tabular}{l}
$\begin{array}{l}\text { Absorbed } \\
\text { Dose Rate } \\
\text { (mrad/hr) }\end{array}$ \\
\hline $3.04 \pm 2.13^{(\mathrm{a})}$
\end{tabular}

Proton Drop

Point

Channel \#

123

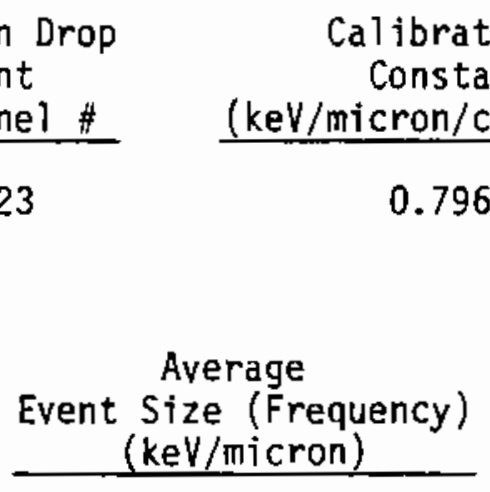

Kellerer Approximation

\begin{tabular}{lc}
$\begin{array}{l}\text { Average } \\
\text { Quality }\end{array}$ & $\begin{array}{c}\text { Dose EquivaTent } \\
\text { Rate } \\
\text { Factor }\end{array}$ \\
\hline
\end{tabular}

2.8

9

Borak Approximation

\begin{tabular}{lc}
$\begin{array}{l}\text { Average } \\
\text { Quality }\end{array}$ & Dose Equivalent \\
Rate \\
Factor & (mrem/hr) \\
\hline
\end{tabular}

3.9

12

13.1

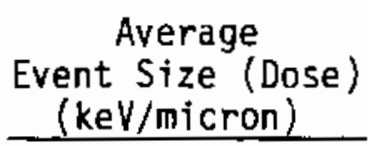

13.1
Tota 1 Neutron Events (Counts)

$3.41 \times 10^{4}$
Tota? Neutron Dose Events (Counts $\times$ Channel)

$5.59 \times 10^{5}$

(a) One standard deviation from Poisson statistics. 
TABLE A.17. Site 1 (BWR) Neutron Measurement 5

Location $\quad \frac{\begin{array}{c}\text { SNOOPY } \\ \text { DE Rate } \\ (\mathrm{mrem} / \mathrm{hr})\end{array}}{100} \quad \frac{\begin{array}{c}\text { Multisphere } \\ \text { DE Rate } \\ (\mathrm{mrem} / \mathrm{hr})\end{array}}{49} \quad \frac{\text { Date }}{12 / 29 / 82}$

$\underline{\text { TEPC \# }}$

502

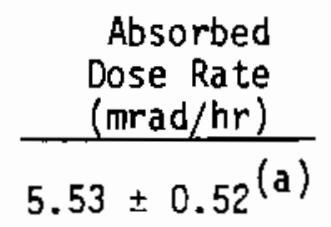

Absorbed

Dose Rate

$5.53 \pm 0.52^{(a)}$
Kellerer Approximation

\begin{tabular}{ll}
$\begin{array}{c}\text { Average } \\
\text { Quality } \\
\text { Factor }\end{array}$ & $\begin{array}{c}\text { Dose Equivalent } \\
\text { Rate } \\
\text { (mrem/hr) }\end{array}$ \\
\hline 8.8 & 486
\end{tabular}

TEPC Diameter

(cm)

12.7
Live Time $(\mathrm{sec})$

3035

\section{Proton Drop \\ Point \\ Channel\#}

137

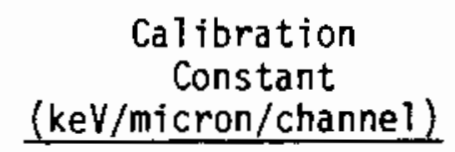

0.7153

$$
\frac{\begin{array}{l}
\text { Tota } 7 \\
\text { Neutron Events } \\
\text { (Counts) }
\end{array}}{6.36 \times 10^{4}}
$$

Borak Approximation

\begin{tabular}{lc}
$\begin{array}{l}\text { Average } \\
\text { Quality } \\
\text { Factor }\end{array}$ & $\begin{array}{c}\text { Dose Equivalent } \\
\text { Rate } \\
\text { (mrem/hr) }\end{array}$ \\
\hline 11.2 & 618
\end{tabular}

Average
Event Size (Frequency)
$($ keV/micron)

38.6

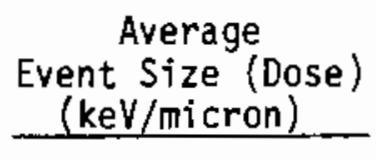

50.3
Total Neutron Dose Events (Counts $\times$ Channel)

$3.44 \times 10^{6}$

(a) One standard deviation from Poisson statistics. 
TABLE A.18. Si te 1 (BWR) Gamma Measurement 5

Location $\quad \frac{\begin{array}{c}\text { Reference } \\ \text { DE Rate } \\ (\mathrm{mrem} / \mathrm{hr})\end{array}}{60} \quad \frac{\text { Date }}{12 / 29 / 82}$

Site Equivalent

Diameter

TEPC \# (micrometers)

TEPC Diameter
$(\mathrm{cm})$$\quad \begin{gathered}\text { Live Time } \\ (\mathrm{sec})\end{gathered}$

502

$\frac{\begin{array}{l}\text { Absorbed } \\ \text { Dose Rate } \\ (\mathrm{mrad} / \mathrm{hr})\end{array}}{0.40 \pm 0.20^{(\mathrm{a})}}$

\begin{tabular}{|c|c|}
\hline $\mathrm{Ke}$ & \\
\hline $\begin{array}{l}\text { Average } \\
\text { Quality } \\
\text { Factor }\end{array}$ & $\begin{array}{c}\text { Dose Equivalent } \\
\text { Rate } \\
\text { (mrem/hr) }\end{array}$ \\
\hline
\end{tabular}

2.7

1

\begin{tabular}{|c|c|}
\hline & \\
\hline $\begin{array}{l}\text { Average } \\
\text { Quality } \\
\text { Factor }\end{array}$ & $\begin{array}{l}\text { Dose Equivalent } \\
\text { Rate } \\
\text { (mrem/hr) }\end{array}$ \\
\hline
\end{tabular}

3.7 \begin{tabular}{l} 
Proton Drop \\
Point \\
Channel \# \\
\hline
\end{tabular}

137

\begin{tabular}{c} 
Calibration \\
Constant \\
(kev/micron/channel) \\
\hline
\end{tabular}

0.07153

$\frac{\begin{array}{c}\text { Tota } 1 \\ \text { Neutron Events } \\ \text { (Counts) }\end{array}}{1.44 \times 10^{4}}$

Tota 1
$\frac{\begin{array}{l}\text { Neutron Dose Events } \\ \text { (Counts } \times \text { Channe1) }\end{array}}{2.46 \times 10^{5}}$

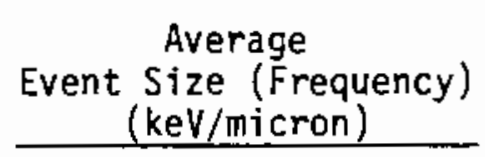

12.3

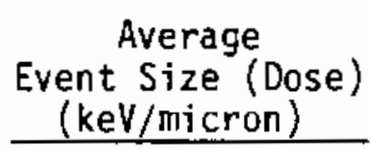

12.3
Average LET (Dose) (keV/micron)

11.0

(a) One standard deviation from Poisson statistics. 
TABLE A.19. Site 2 (BWR) Neutron Measurement 1

\begin{tabular}{|c|c|c|c|}
\hline Location & $\begin{array}{c}\text { SNOOPY } \\
\text { DE Rate } \\
\text { (mrem/hr) }\end{array}$ & $\begin{array}{c}\text { Multisphere } \\
\text { DE Rate } \\
\text { (mrem/hr) }\end{array}$ & Date \\
\hline 1 & 450 & 450 & $2 / 6 / 83$ \\
\hline
\end{tabular}

\begin{tabular}{|c|c|c|c|}
\hline TEPC \# & $\begin{array}{c}\text { Site Equivalent } \\
\text { Diameter } \\
\text { (micrometers) } \\
\end{array}$ & $\begin{array}{c}\text { TEPC Diameter } \\
(\mathrm{cm}) \\
\end{array}$ & $\begin{array}{c}\text { Live Time } \\
(\mathrm{sec})\end{array}$ \\
\hline 502 & 2.1 & 12.7 & 1000 \\
\hline
\end{tabular}

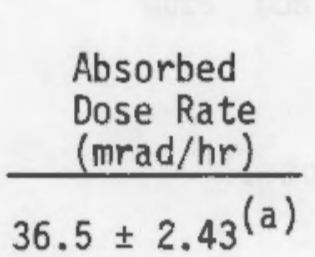

\begin{tabular}{l} 
Proton Drop \\
Point \\
Channel \# \\
\hline
\end{tabular}

236

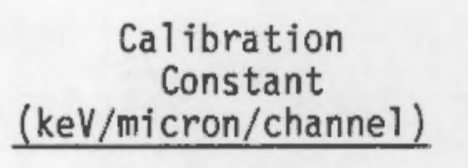

0.4144
Kellerer Approximation

Average Dose Equivalent Quality Factor

10.1

369
Borak Approximation

\begin{tabular}{cc}
$\begin{array}{c}\text { Average } \\
\text { Quality } \\
\text { Factor }\end{array}$ & $\begin{array}{c}\text { Dose Equivalent } \\
\text { Rate } \\
\text { (mrem/hr) }\end{array}$ \\
\hline 11.9 & 436
\end{tabular}

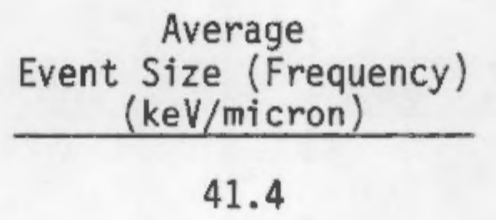

Average

41.4

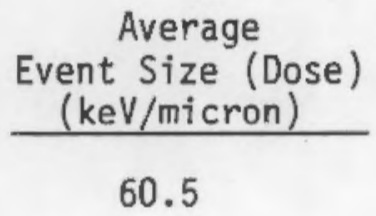

Total Neutron Events (Counts)

$1.29 \times 10^{5}$
Total Neutron Dose Events (Counts $\times$ Channel)

$1.29 \times 10^{7}$

(a) One standard deviation from Poisson statistics. 


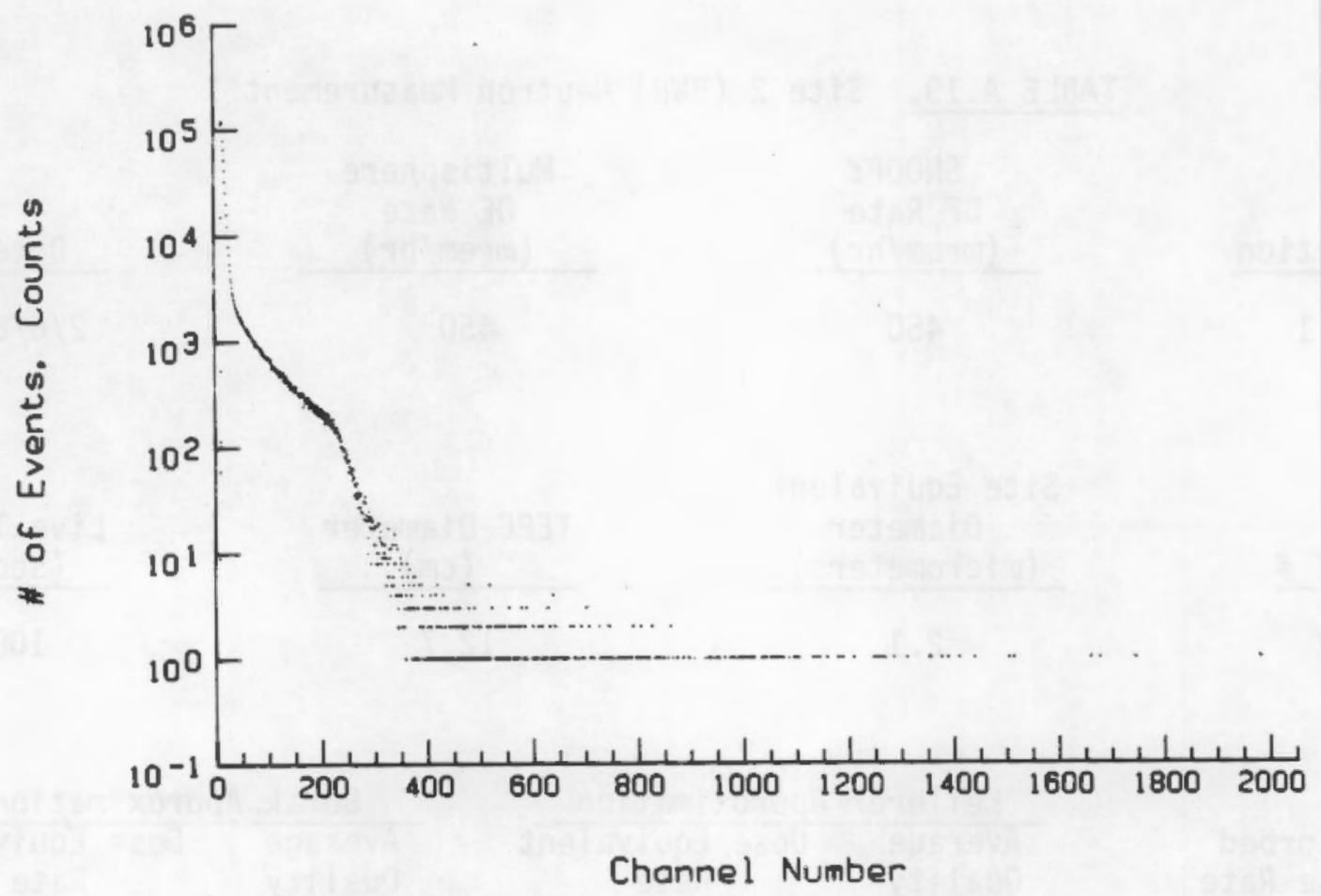

FIGURE A.17. Raw Data for Site 2 Neutron Measurement 1

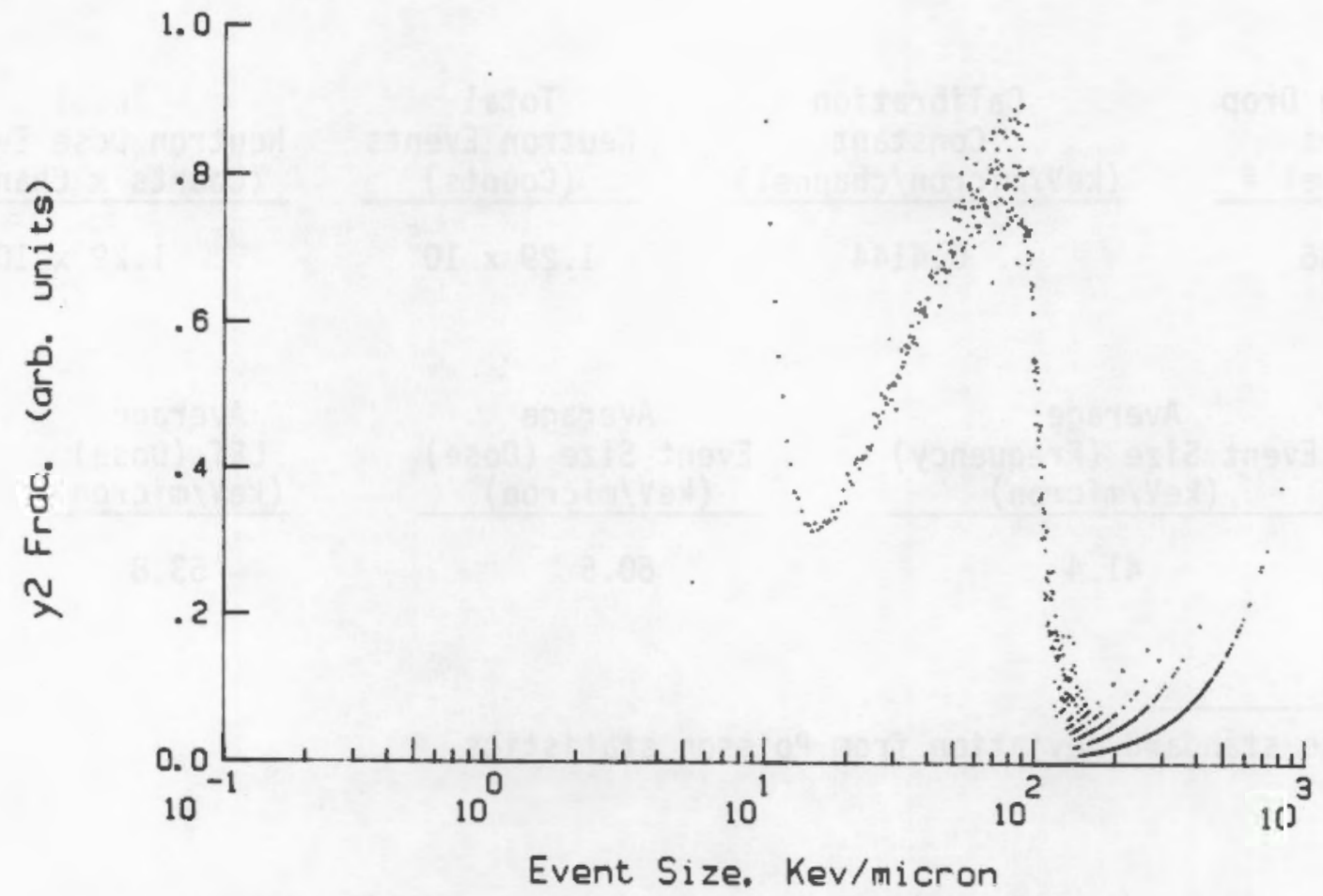

FIGURE A.18. $\quad Y^{2}$ Distribution for Site 2 Neutron Measurement 1 
IABLE A.20. Site 2 Gamma Measurement 1

Location $\quad \frac{\begin{array}{c}\text { Reference } \\ \text { DE Rate } \\ \text { (mrem/hr) }\end{array}}{470} \quad \frac{\text { Date }}{2 / 6 / 83}$

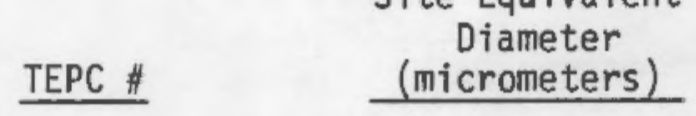

502

$$
2.1
$$

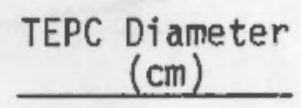

12.7
Live Time (sec)

1000
Kellerer Approximation

\begin{tabular}{lc}
\hline Average & Dose Equivalent \\
Quality & Rate \\
Factor & (mrem/hr) \\
\hline
\end{tabular}

1.0

232
Borak Approximation

\begin{tabular}{lc}
\hline Average & Dose Equivalent \\
Quality & Rate \\
Factor & $(\mathrm{mrem} / \mathrm{hr})$ \\
\hline
\end{tabular}

1.3

304

\begin{tabular}{|c|c|c|c|}
\hline $\begin{array}{l}\text { Proton Drop } \\
\text { Point } \\
\text { Channel \# }\end{array}$ & $\begin{array}{c}\text { Calibration } \\
\text { Constant } \\
\text { (keV/micron/channel) } \\
\end{array}$ & $\begin{array}{l}\text { Total } \\
\text { Neutron Events } \\
\text { (Counts) } \\
\end{array}$ & $\begin{array}{l}\text { Total } \\
\text { Neutron Dose Events } \\
\text { (Counts } \times \text { Channel) } \\
\end{array}$ \\
\hline 1467 & 0.0667 & $1.83 \times 10^{7}$ & $5.09 \times 10^{8}$ \\
\hline
\end{tabular}

Average

Event Size (Frequency) (keV/micron)

1.9

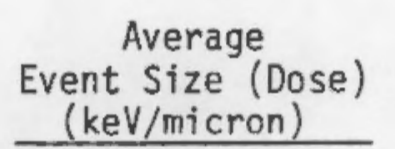

2.8
Average LET (Dose) (keV/micron)

2.5

(a) Portable ion chamber.

(b) One standard deviation from Poisson statistics. 


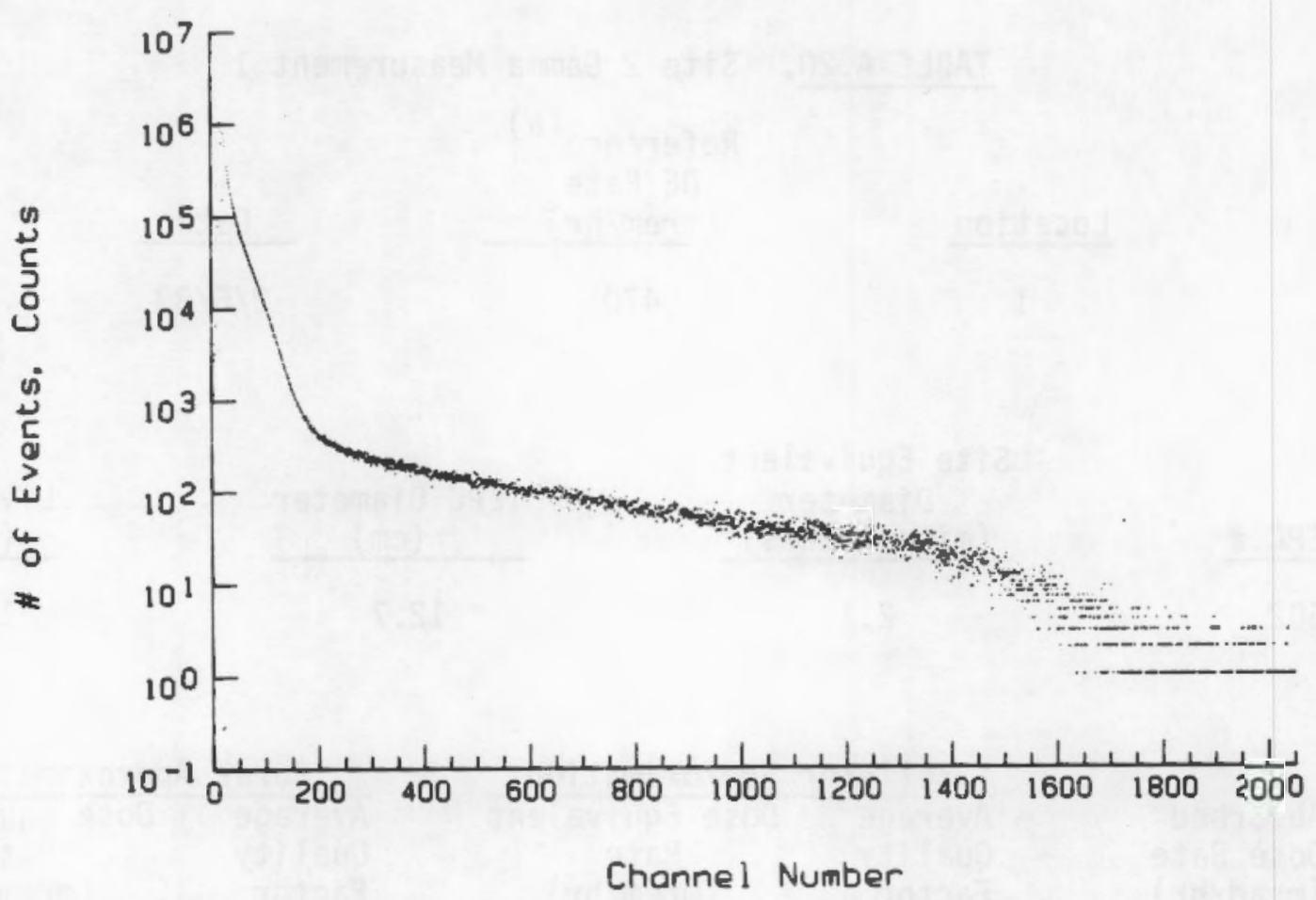

FIGURE A.19. Raw Data for Site 2 Gamma Measurement 1

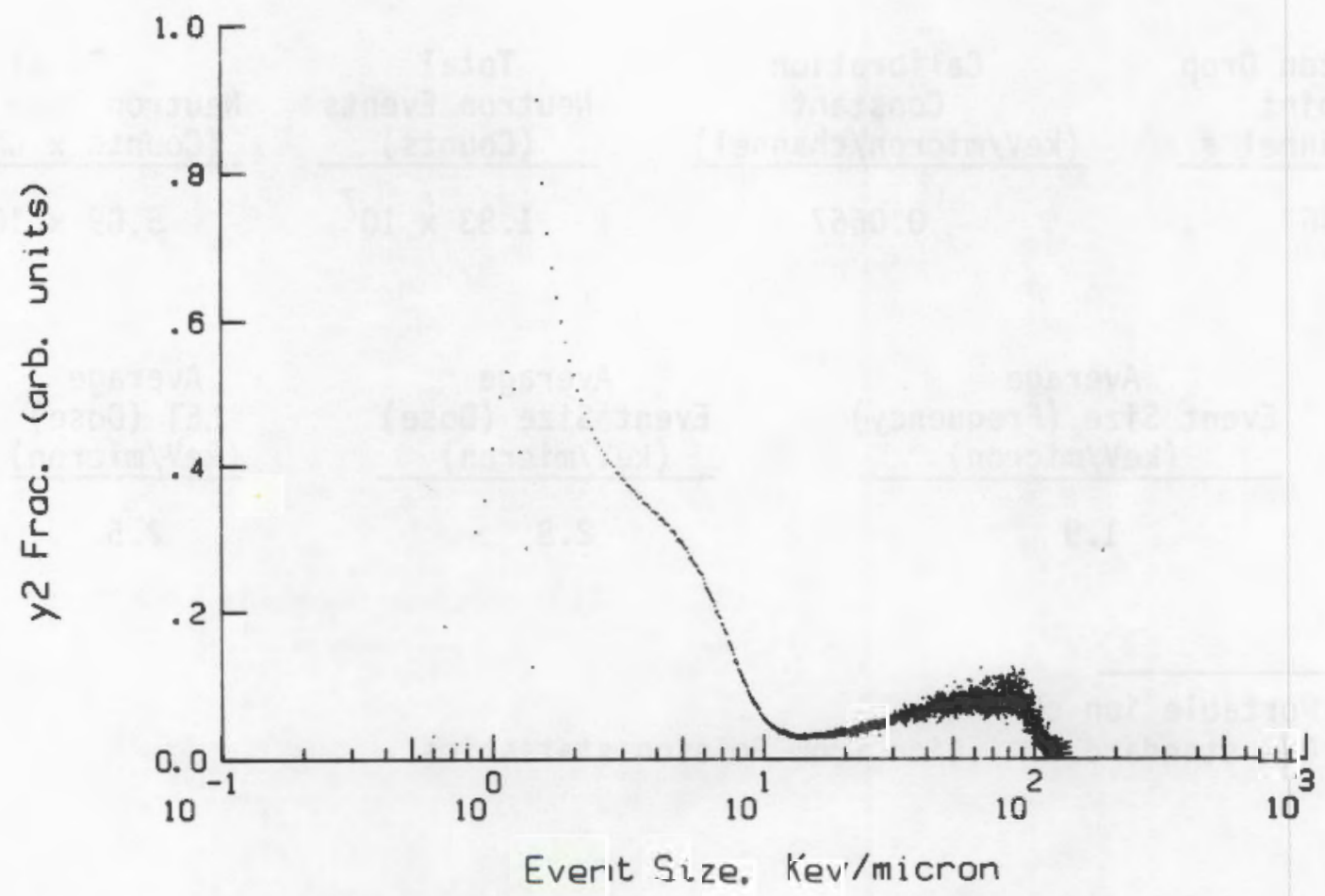

FIGURE A.20. $Y^{2}$ Distribution for Site 2 Gamma Measurement 1 
TABLE A.21. Site 2 Neutron Measurement 2

\begin{tabular}{|c|c|c|c|}
\hline Location & $\begin{array}{c}\text { SNOOPY } \\
\text { DE Rate } \\
\text { (mrem } / \mathrm{hr} \text { ) }\end{array}$ & $\begin{array}{c}\text { Multisphere } \\
\text { DE Rate at } \\
\text { (mrem/hr) }\end{array}$ & Date \\
\hline 2 & 450 & 450 & $2 / 6 / 83$ \\
\hline
\end{tabular}

$\frac{\text { TEPC \# }}{502} \quad \frac{\begin{array}{c}\text { Diameter } \\ \text { (micrometers) }\end{array}}{2.1}$

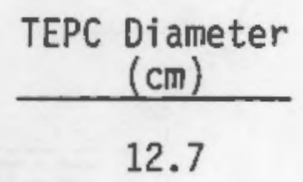

Live Time (sec)

9301

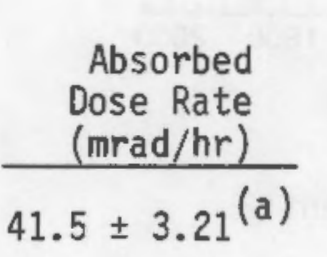

\begin{tabular}{|c|c|}
\hline Kellere & Approxiludivalent \\
\hline $\begin{array}{l}\text { Quality } \\
\text { Factor }\end{array}$ & $\begin{array}{l}\text { Rate } \\
\text { (mrem/hr) }\end{array}$ \\
\hline
\end{tabular}

10.9

450
Borak Approximation

\begin{tabular}{cc}
$\begin{array}{c}\text { Average } \\
\text { Quality }\end{array}$ & $\begin{array}{c}\text { Dose Equivalent } \\
\text { Rate } \\
\text { (mrem/hr) }\end{array}$ \\
\hline
\end{tabular}

12.3

\begin{tabular}{|c|c|c|c|}
\hline $\begin{array}{l}\text { Proton Drop } \\
\text { Point } \\
\text { Channel } \\
\end{array}$ & $\begin{array}{c}\text { Calibration } \\
\text { Constant } \\
\text { (keV/micron/channel) } \\
\end{array}$ & $\begin{array}{c}\text { Total } \\
\text { Neutron Events } \\
\text { (Counts) } \\
\end{array}$ & $\begin{array}{l}\text { Total } \\
\text { Neutron Dose Events } \\
\text { (Counts } \times \text { Channel) } \\
\end{array}$ \\
\hline 156 & 0.6269 & $1.37 \times 10^{6}$ & $9.01 \times 10^{7}$ \\
\hline
\end{tabular}

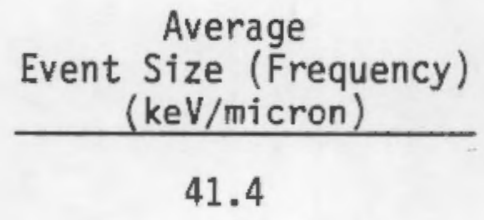

Average $\mathrm{keV} /$ micron)

41.4
Average Event Size (Dose) (keV/micron)

66.7
Average LET (Dose) (keV/micron)

59.3

(a) One standard deviation from Poisson statistics. 


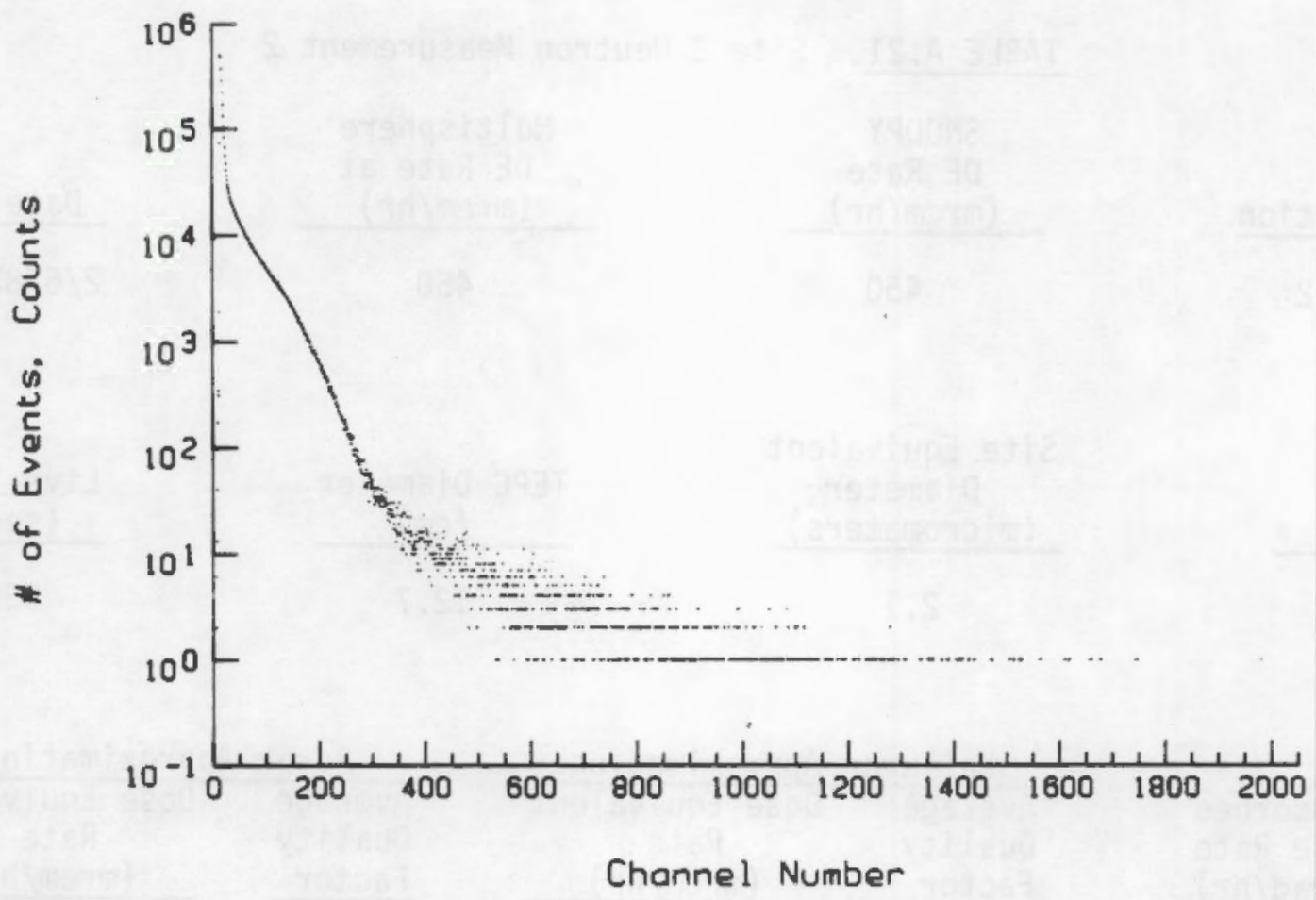

FIGURE A.21. Raw Data for Site 2 Neutron Measurement 2

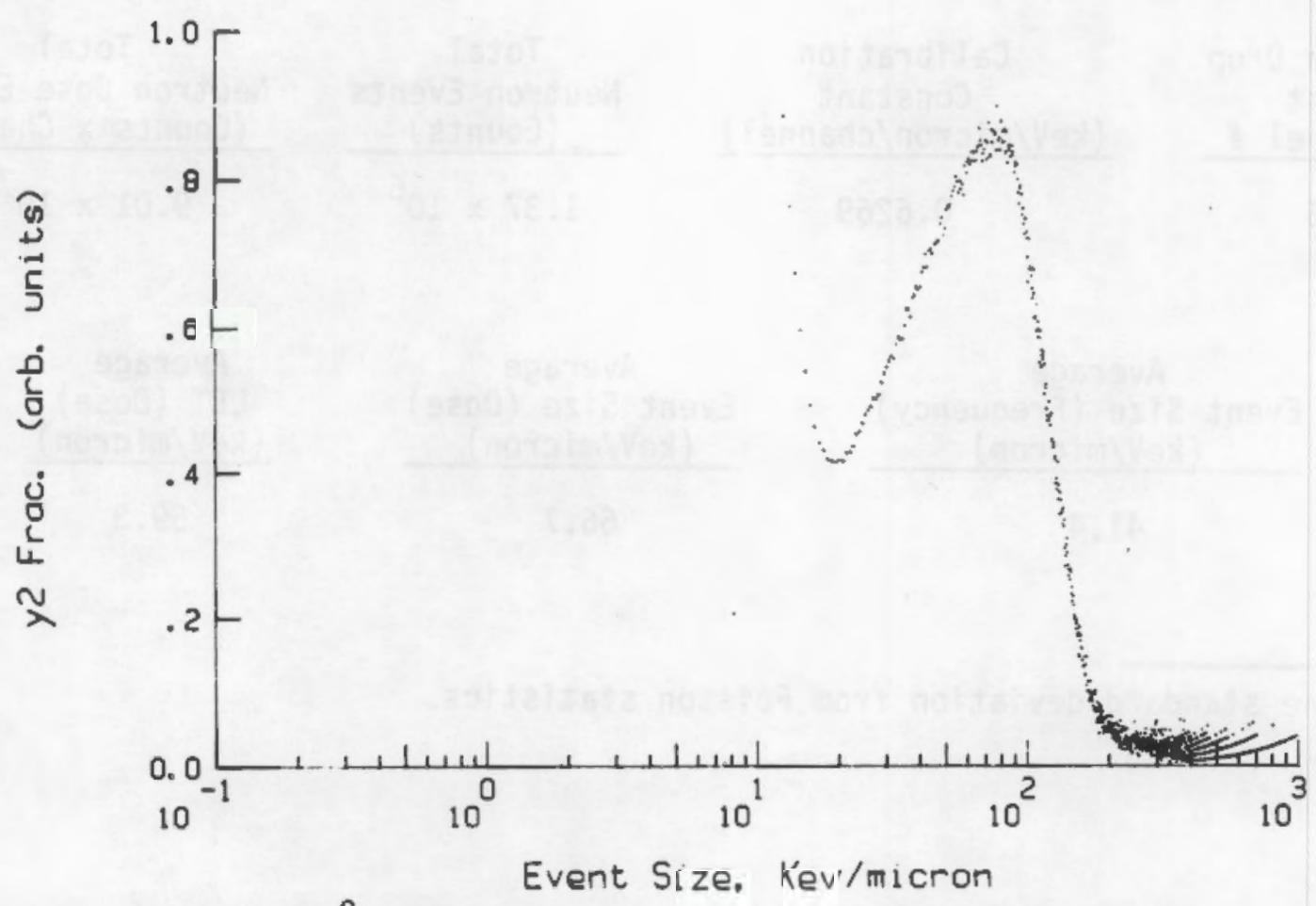

FIGURE A.22. $y^{2}$ Distribution for Site 2 Neutron Measurement 2 
TABLE A.22. Site 2 Gamma Measurement 2

Location $\quad \frac{\begin{array}{c}\text { Reference } \\ \text { DE Rate } \\ \text { (mrem/hr) }\end{array}}{470} \quad \frac{\text { Date }}{2 / 6 / 83}$

$\underline{\text { TEPC \# }}$

502

$\begin{array}{r}\text { Absorbed } \\ \text { Dose Rate } \\ \text { (mrad/hr) } \\ \hline\end{array}$

$70.7 \pm 8.23^{(b)}$
Kellerer Approximation

\begin{tabular}{lc}
$\begin{array}{l}\text { Average } \\
\text { Quality }\end{array}$ & Dose Equivalent \\
Rate \\
Factor & (mrem/hr) \\
\hline
\end{tabular}

1.0

71
TEPC Diameter

(cm)

12.7
Live Time (sec)

8030

\section{Proton Drop \\ Point \\ Channel \#}

1506

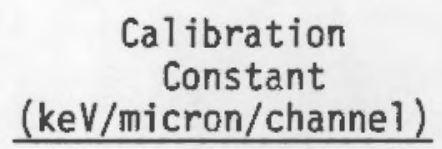

0.0649
Borak Approximation

\begin{tabular}{cc}
$\begin{array}{l}\text { Average } \\
\text { Quality }\end{array}$ & $\begin{array}{c}\text { Dose Equivalent } \\
\text { Rate } \\
\text { (mrem/hr) }\end{array}$ \\
\hline Factor &
\end{tabular}

1.4

100
Average

Event Size (Frequency) (keV/micron)

$$
2.5
$$

Average

Event Size (Dose) (keV/micron)

$$
3.4
$$

Total Neutron Dose Events (Counts $\times$ Channel)

$1.28 \times 10^{9}$

(a) Portable ion chamber.

(b) One standard deviation from Poisson statistics. 


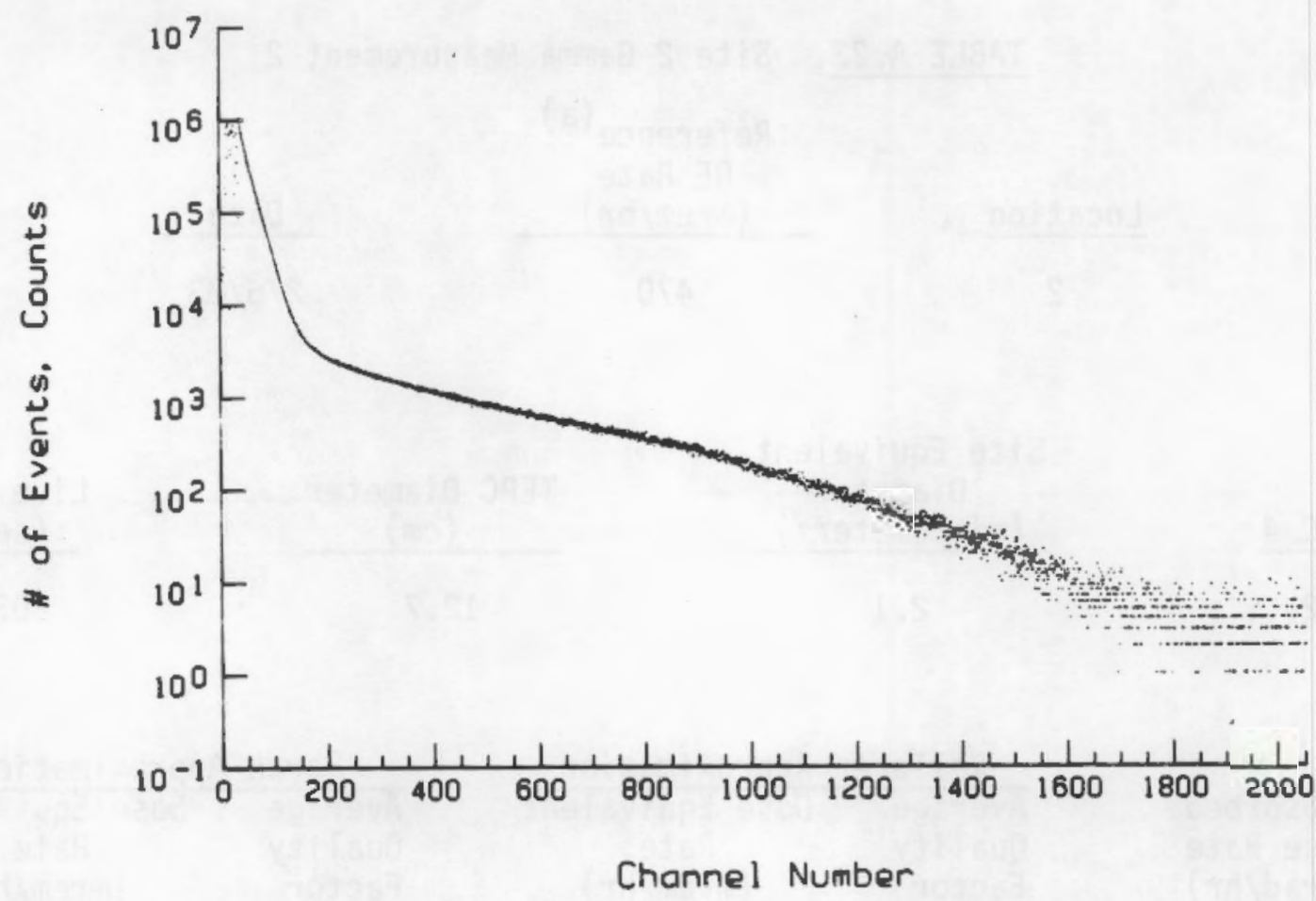

FIGURE A.23. Raw Data for Site 2 Gamma Measurement 2

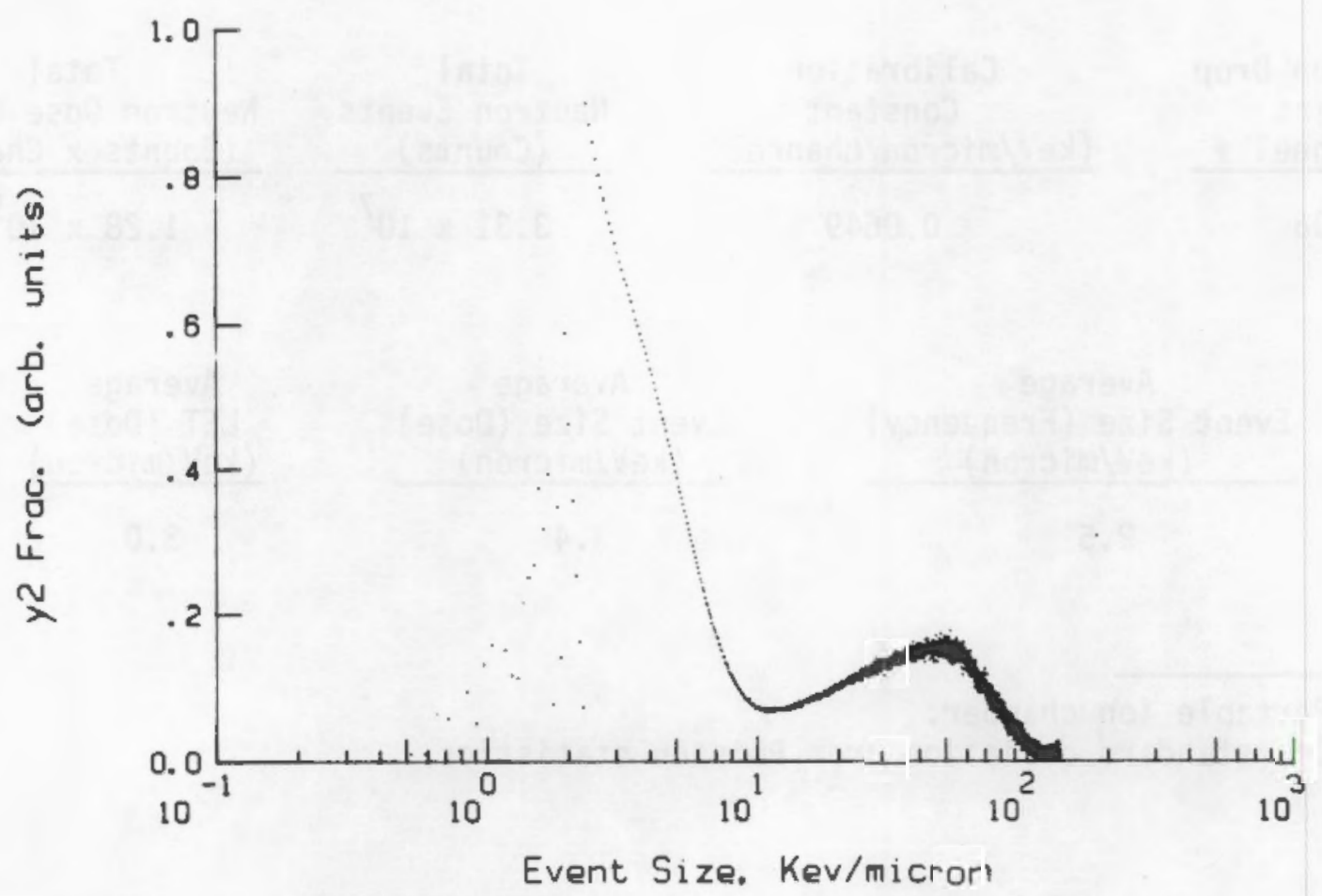

FIGURE A.24. $Y^{2}$ Distribution for Site 2 Gamma Measurement 2 
TABLE A.23. Site 2 Neutron Measurement 3

\begin{tabular}{|c|c|c|c|}
\hline Source \# & $\begin{array}{l}\text { SNOOPY } \\
\text { DE Rate } \\
\text { (mrem/hr) }\end{array}$ & $\begin{array}{c}\text { Multisphere } \\
\text { DE Rate at } \\
\text { (mrem/hr) }\end{array}$ & Date \\
\hline 3 & - & - & $2 / 6 / 83$ \\
\hline
\end{tabular}

\begin{tabular}{|c|c|c|c|}
\hline TEPC \# & $\begin{array}{c}\text { Site Equivalent } \\
\text { Diameter } \\
\text { (micrometers) }\end{array}$ & $\begin{array}{l}\text { TEPC Diameter } \\
(\mathrm{cm})\end{array}$ & $\begin{array}{c}\text { Live Time } \\
(\mathrm{sec})\end{array}$ \\
\hline 501 & 2.1 & 12.7 & 1460 \\
\hline
\end{tabular}

\begin{tabular}{|c|c|c|c|c|}
\hline \multirow[b]{2}{*}{$\begin{array}{l}\text { Absorbed } \\
\text { Dose Rate } \\
\text { (mrad/hr) }\end{array}$} & \multicolumn{2}{|c|}{ Kellerer Approximation } & \multicolumn{2}{|c|}{ Borak Approximation } \\
\hline & $\begin{array}{ll}\text { Average } & \text { Dose } \\
\text { Quality } & \\
\text { Factor } & \text { (m }\end{array}$ & $\begin{array}{l}\text { ivalent } \\
\text { (hr) }\end{array}$ & $\begin{array}{l}\text { Aver } \\
\text { Oual } \\
\text { Fact } \\
\end{array}$ & $\begin{array}{cc}\text { e } & \text { Dose Equivalent } \\
\text { y } & \text { Rate } \\
\text { (mrem } / \mathrm{hr}) \\
\end{array}$ \\
\hline $1.81 \pm 0.15^{(a)}$ & 9.5 & & & 21 \\
\hline $\begin{array}{l}\text { Proton Drop } \\
\text { Point } \\
\text { Channel \# } \\
\end{array}$ & $\begin{array}{c}\text { Calibration } \\
\text { Constant } \\
(\mathrm{keV} / \text { micron/channel) } \\
\end{array}$ & $\begin{array}{r}\text { Tc } \\
\text { Neutrc } \\
\quad(\mathrm{Cc} \\
\end{array}$ & $\begin{array}{l}\text { vents } \\
\text { s) }\end{array}$ & $\begin{array}{l}\text { Total } \\
\text { Neutron Dose Events } \\
\text { (Counts } \times \text { Channel) } \\
\end{array}$ \\
\hline 173 & 0.5653 & 9.57 & $10^{3}$ & $6.85 \times 10^{4}$ \\
\hline $\begin{array}{r}\mathrm{Av} \\
\text { Event } \begin{array}{r}\mathrm{Siz} \\
(\mathrm{keV}\end{array} \\
\end{array}$ & $\begin{array}{l}\text { erage } \\
\text { (Frequency) } \\
\text { (micron) }\end{array}$ & $\begin{array}{l}\text { Average } \\
\text { it Size ( } \\
\text { reV/micro }\end{array}$ & & $\begin{array}{c}\text { Average } \\
\text { LET (Dose) } \\
\text { (keV/micron) } \\
\end{array}$ \\
\hline & & 56.0 & & 49.8 \\
\hline
\end{tabular}

(a) One standard deviation from Poisson statistics. 


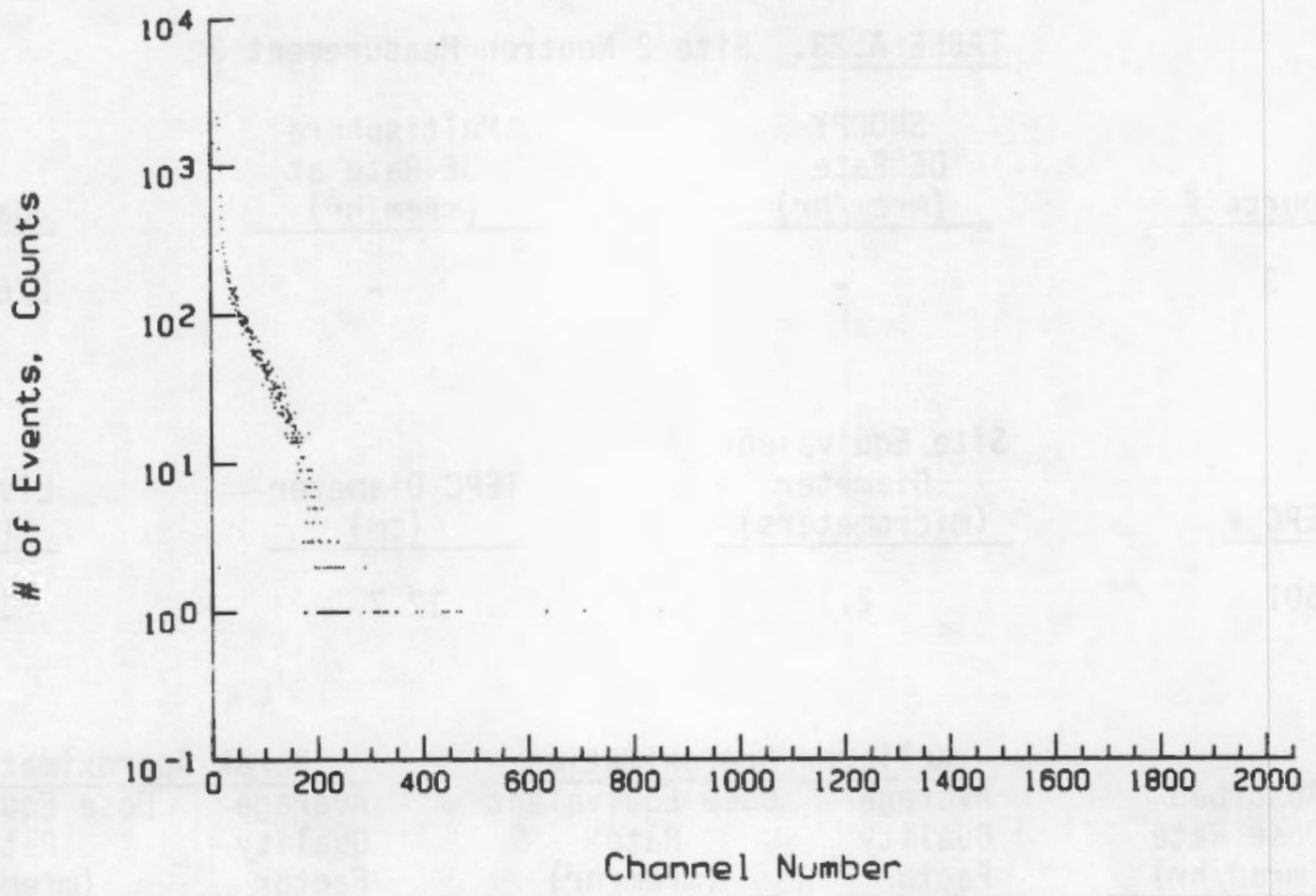

FIGURE A.25. Raw Data for Site 2 Neutron Measurement 3

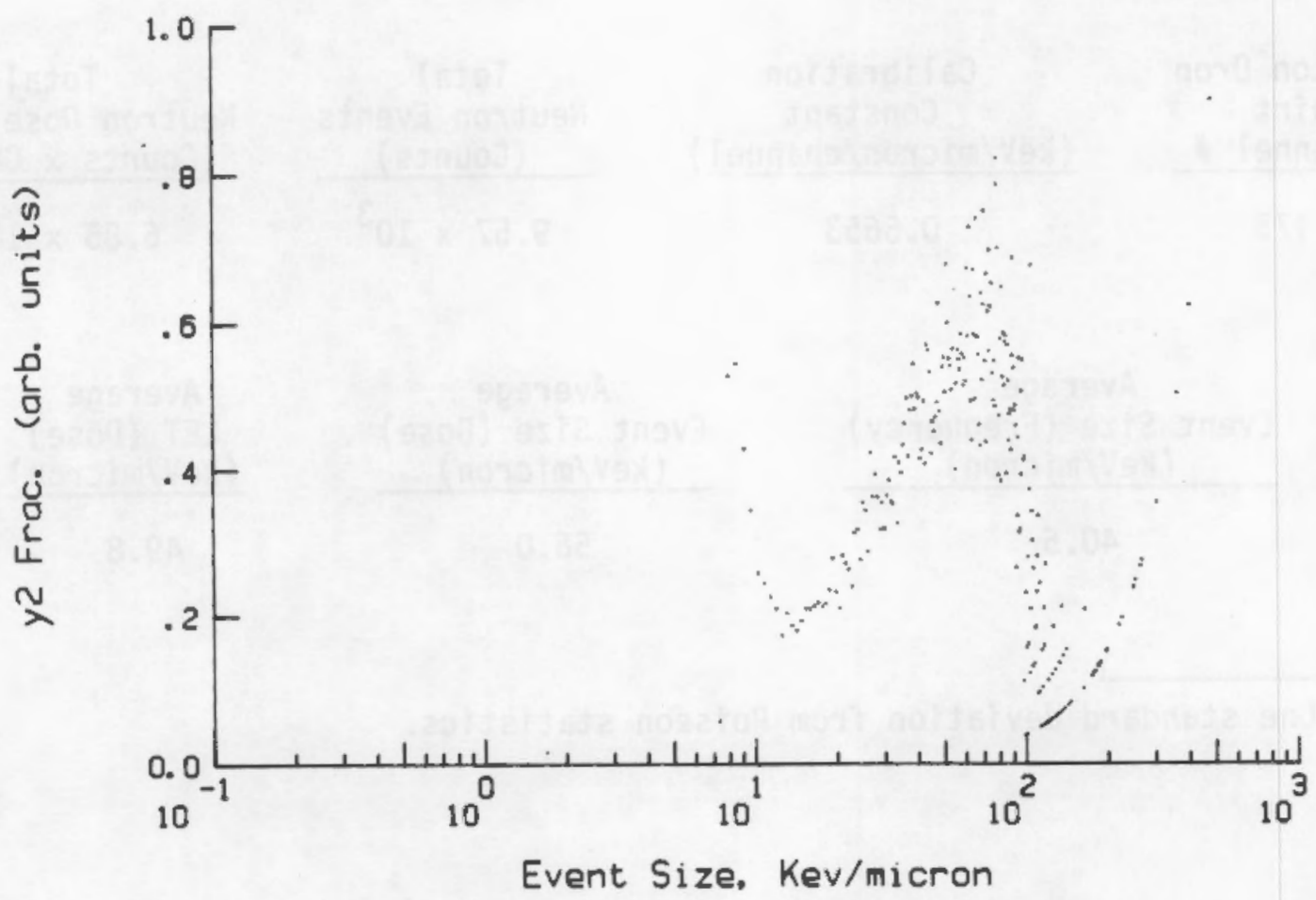

FIGURE A.26. $r^{2}$ Distribution for Site 2 Neutron Measurement 3 
TABLE A.24. Site 2 Gamma Measurement 3

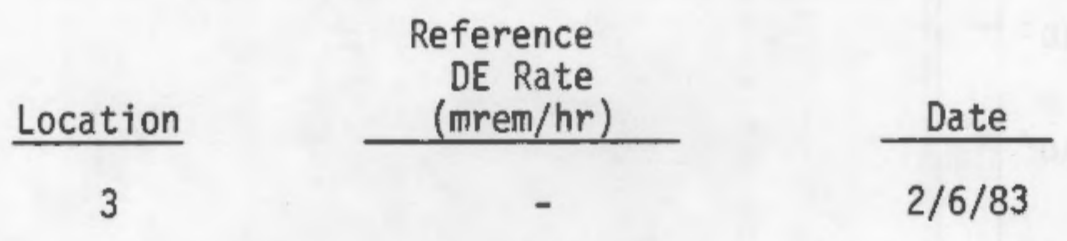

TEPC \#

502
Site Equivalent

Diameter

(micrometers)

2.1
TEPC Diameter

(cm)

12.7
Live Time (sec)

1300 \begin{tabular}{l} 
Absorbed \\
Dose Rate \\
(mrad/hr) \\
\hline
\end{tabular}

$113 \pm 28.9^{(a)}$
Kellerer Approximation

\begin{tabular}{cc}
\hline $\begin{array}{c}\text { Average } \\
\text { Quality }\end{array}$ & $\begin{array}{c}\text { Dose Equivalent } \\
\text { Rate } \\
\text { Factor }\end{array}$ \\
\cline { 2 - 2 } & (mrem/hr) \\
\hline
\end{tabular}

1.0

113
Borak Approximation Average Dose Equivalent Quality Factor

1.2 Rate (mrem/hr)

132
Proton Drop
Point
Channel \#

796

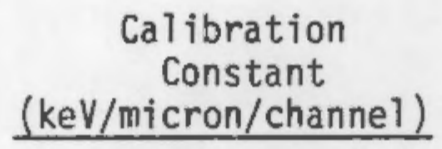

D. 1229
Total Neutron Events (Counts)

$9.15 \times 10^{6}$
Total Neutron Dose Events (Counts $\times$ Channel)

$1.75 \times 10^{8}$
Average

Event Size (Frequency) (keV/micron)

2.4

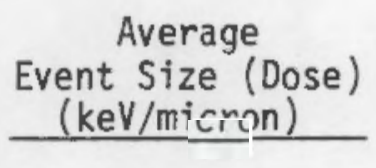

2.6
Average LET (Dose) ( $\mathrm{keV} /$ micron)

2.3

(a) Portable ion chamber. 


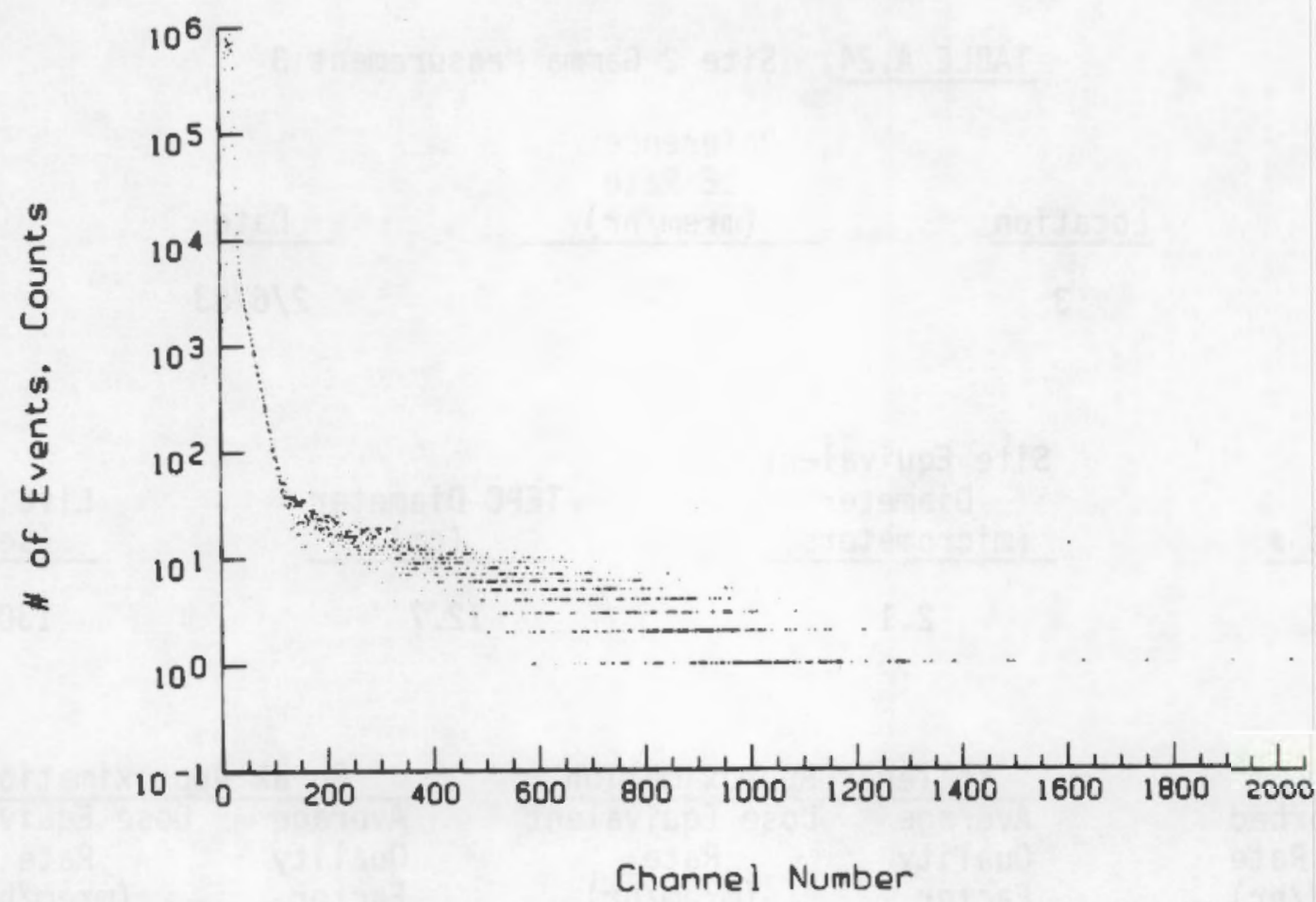

FIGURE A.27. Raw Data for Site 2 Gamma Measurement 3

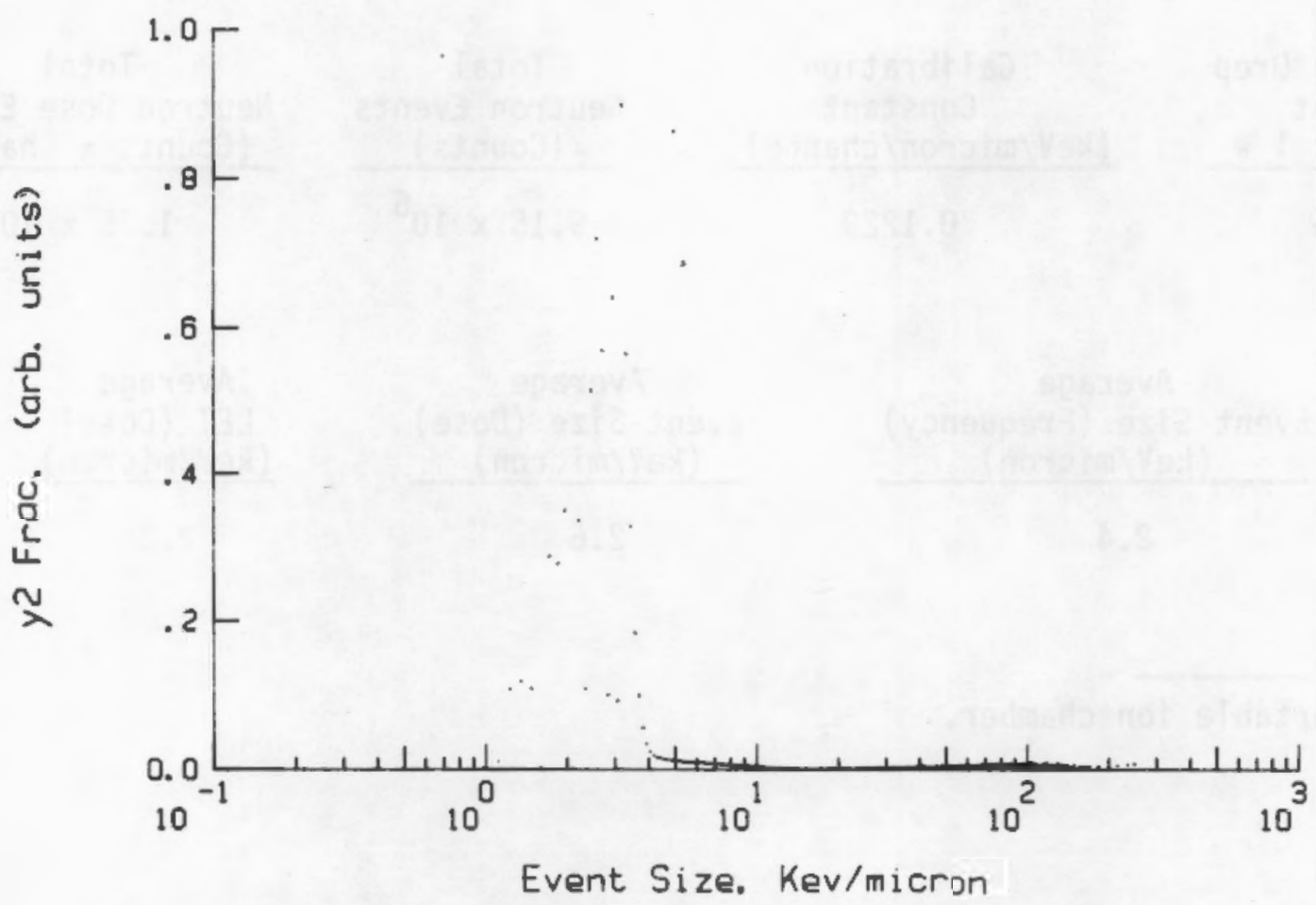

FIGURE A.28. $Y^{2}$ Distribution for Site 2 Gamma Measurement 3 
TABLE A.25. Site 2 Neutron Measurement 4

\begin{tabular}{|c|c|c|c|}
\hline Source \# & $\begin{array}{l}\text { SNOOPY } \\
\text { DE Rate } \\
\text { (mrem/hr) }\end{array}$ & $\begin{array}{c}\text { Multisphere } \\
\text { OE Rate } \\
\text { (mrem } / \mathrm{hr} \text { ) }\end{array}$ & Date \\
\hline 4 & - & - & $2 / 6 / 83$ \\
\hline TEPC \# & $\begin{array}{c}\text { Site Equivalent } \\
\text { Diameter } \\
\text { (micrometers) } \\
\end{array}$ & $\begin{array}{c}\text { TEPC Diameter } \\
(\mathrm{cm}) \\
\end{array}$ & $\begin{array}{c}\text { Live Time } \\
(\mathrm{sec})\end{array}$ \\
\hline 502 & 2.1 & 12.7 & 1021 \\
\hline
\end{tabular}

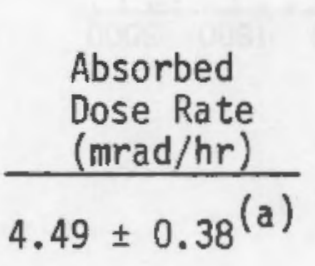

Kellerer Approximation

\begin{tabular}{lc}
\hline Average & Dose Equivalent \\
Quality & Rate \\
Factor & (mrem/hr) \\
\hline
\end{tabular}

9.8

44
Borak Approximation

\begin{tabular}{lc}
\hline Average & Dose Equivalent \\
Ouality & Rate \\
Factor & (mrem/hr) \\
\hline
\end{tabular}

11.7

53

\begin{tabular}{|c|c|c|c|}
\hline $\begin{array}{l}\text { Proton Orop } \\
\text { Point } \\
\text { Channel \# }\end{array}$ & $\begin{array}{c}\text { Calibration } \\
\text { Constant } \\
\text { (keV/micron/channel) } \\
\end{array}$ & $\begin{array}{l}\text { Total } \\
\text { Neutron Events } \\
\text { (Counts) } \\
\end{array}$ & $\begin{array}{l}\text { Total } \\
\text { Neutron Dose Events } \\
\text { (Counts } \times \text { Channel) } \\
\end{array}$ \\
\hline 152 & 0.6434 & $1.65 \times 10^{4}$ & $1.04 \times 10^{6}$ \\
\hline
\end{tabular}

Average

Event Size (Frequency)

(keV/micron)

40.7
Average

Event Size (Dose)

(keV/micron)

58.1
Average LET (Dose) (keV/micron)

51.6

(a) One standard deviation from Poisson statistics. 


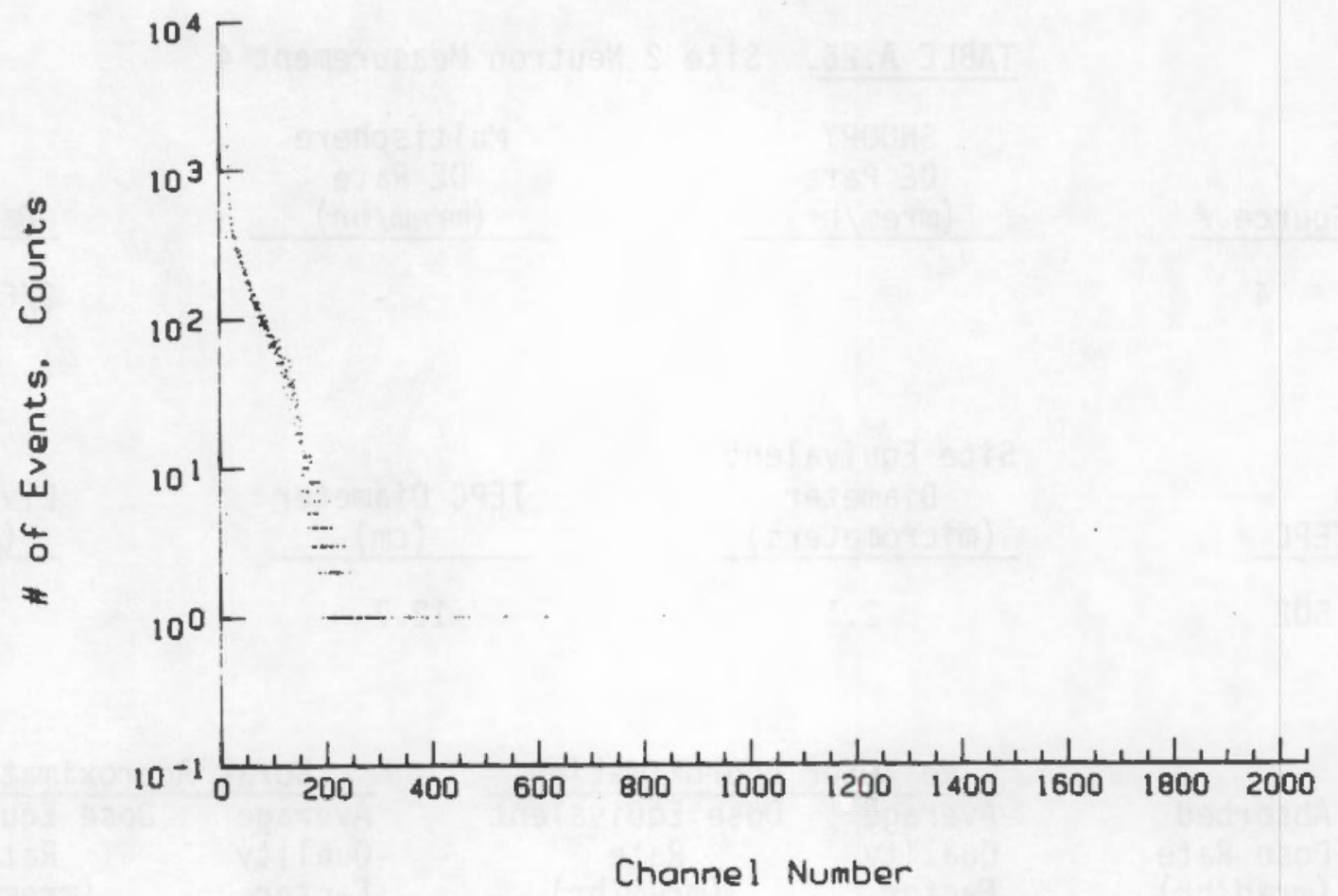

FIGURE A.29. Raw Data Site 2 Neutron Measurement 4

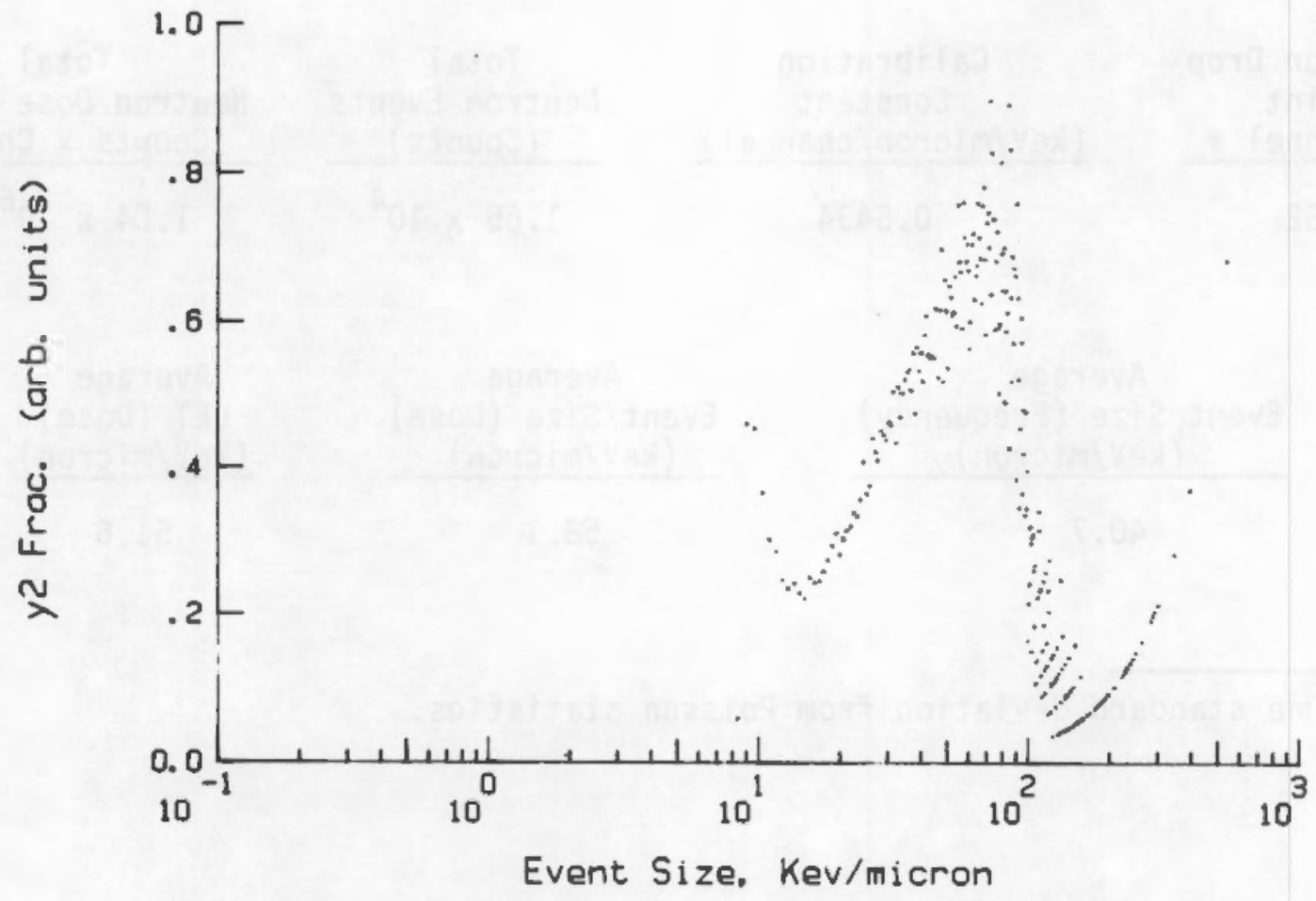

FIGURE A.30. $Y^{2}$ Distribution for Site 2 Neutron Measurement 4 
TABLE A.26. Site 2 Gamma Measurement 4

Location $\quad \frac{\begin{array}{c}\text { Reference } \\ \text { DE Rate } \\ \text { (mrem/hr) }\end{array}}{4} \quad-\quad \frac{\text { Date }}{2 / 6 / 83}$

$\underline{\text { TEPC \# }}$

502 $\frac{\begin{array}{c}\text { Absorbed } \\ \text { Dose Rate } \\ \text { (mrad/hr) }\end{array}}{201 \pm 49.9^{(a)}}$

\begin{tabular}{l} 
Proton Drop \\
Point \\
Channel \# \\
\hline
\end{tabular}

817

\author{
Calibration \\ Constant \\ (keV/micron/channel)
}

0.1197
TEPC Diameter

(cm)

12.7
Live Time

(sec)

900
Kellerer Approximation

\begin{tabular}{lc}
$\begin{array}{l}\text { Average } \\
\text { Quality }\end{array}$ & $\begin{array}{c}\text { Dose Equivalent } \\
\text { Rate } \\
\text { Factor }\end{array}$ (mrem/hr) \\
\hline
\end{tabular}

1.0

201
Borak Approximation

\begin{tabular}{lc}
$\begin{array}{c}\text { Average } \\
\text { Quality }\end{array}$ & $\begin{array}{c}\text { Dose Equivalent } \\
\text { Rate } \\
\text { (mrem/hr) }\end{array}$ \\
\hline 1.1 & $\frac{226}{2 a c t o r}$
\end{tabular}
Average Dose Equivalent Quality Rate

1.1 226

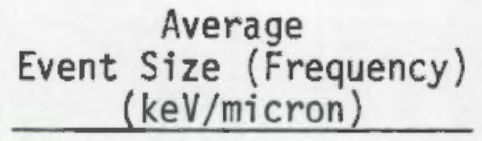

2.3
Average

Event Size (Dose) (keV/micron)

2.5
Total Neutron Events (Counts)

$1.17 \times 10^{7}$
Total Neutron Dose Events (Counts $\times$ Channel) $2.22 \times 10^{8}$

(a) Portable ion chamber. 


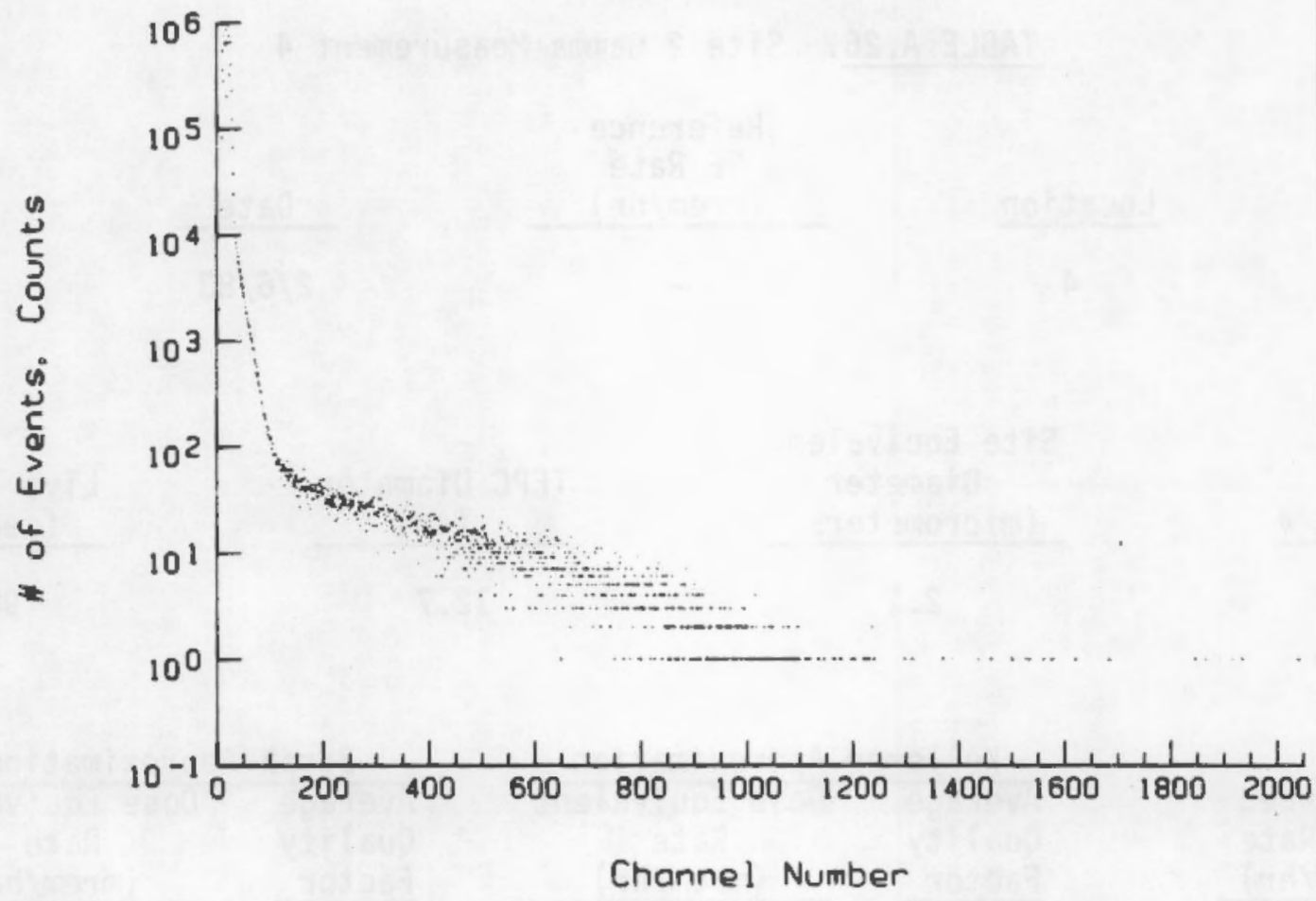

FIGURE A.31. Raw Data for Site 2 Gamma Measurement 4

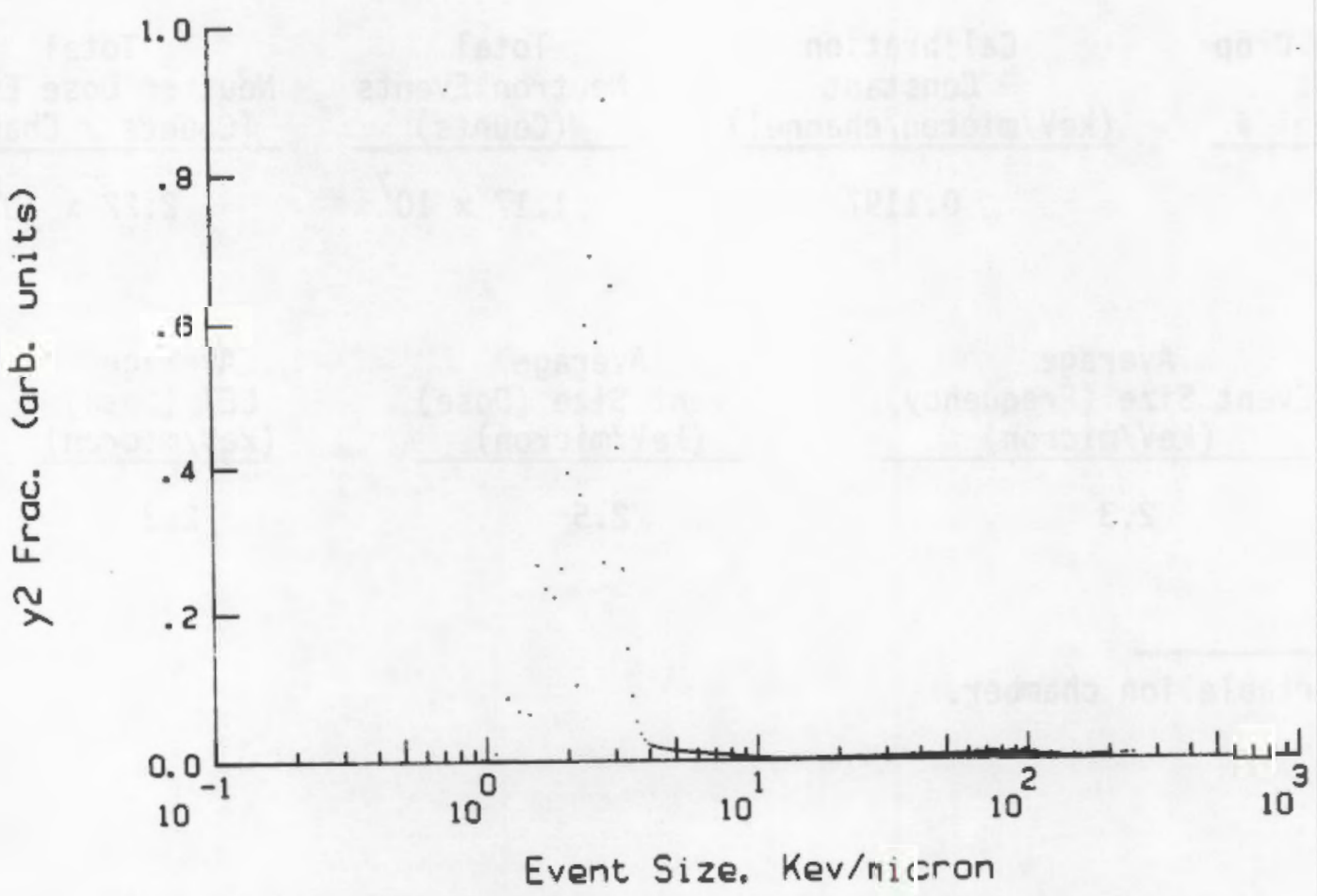

FIGURE A.32. $Y^{2}$ Distribution for Site 2 Gamma Measurement 4 
TABLE A.27. Site 3 Neutron Measurement 1

\begin{tabular}{|c|c|c|c|}
\hline Source \# & $\begin{array}{l}\text { SNOOPY } \\
\text { DE Rate } \\
\text { (mrem/hr) }\end{array}$ & $\begin{array}{c}\text { Multisphere } \\
\text { DE Rate } \\
\text { (mrem/hr) }\end{array}$ & Date \\
\hline 1 & 80 & 84 & $8 / 1 / 83$ \\
\hline TEPC \# & $\begin{array}{c}\text { Site Equivalent } \\
\text { Diameter } \\
\text { (micrometers) }\end{array}$ & $\begin{array}{l}\text { TEPC Diameter } \\
(\mathrm{cm})\end{array}$ & $\begin{array}{l}\text { Live Time } \\
\text { (sec) }\end{array}$ \\
\hline 185 & 1.0 & 12.7 & 1800 \\
\hline
\end{tabular}

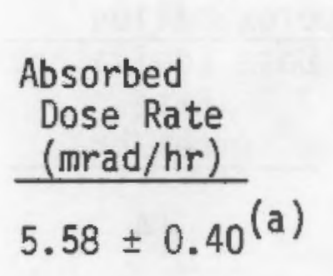

Kellerer Approximation

\begin{tabular}{|c|c|}
\hline $\begin{array}{l}\text { Average } \\
\text { Quality } \\
\text { Factor }\end{array}$ & $\begin{array}{l}\text { Dose Equivalent } \\
\text { Rate } \\
\text { (mrem/hr) }\end{array}$ \\
\hline 9.7 & 54 \\
\hline
\end{tabular}

\begin{tabular}{|c|c|}
\hline $\begin{array}{l}\text { Boral } \\
\text { Average } \\
\text { Quality } \\
\text { Factor }\end{array}$ & $\begin{array}{c}\text { pproximation } \\
\text { Dose Equivalent } \\
\text { Rate } \\
\text { (mrem/hr) }\end{array}$ \\
\hline 11.9 & 66 \\
\hline
\end{tabular}

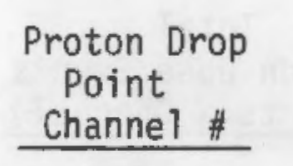

219

\begin{abstract}
Calibration Constant (keV/micron/channel)
\end{abstract}

0.4607

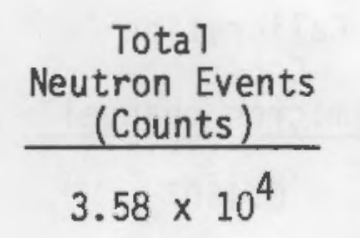
Total Neutron Dose Events (Counts $\times$ Channel)

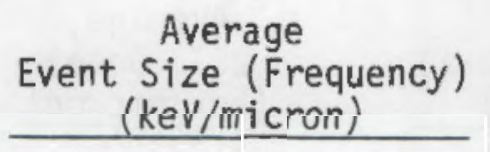

41.1

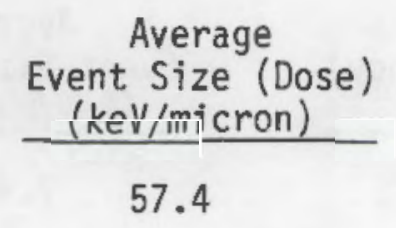

Average
LET (Dose)

(keV/micron)

51.0

(a) One standard deviation from Poisson statistics. 
TABLE A.28. Site 3 Gamma Measurement 1

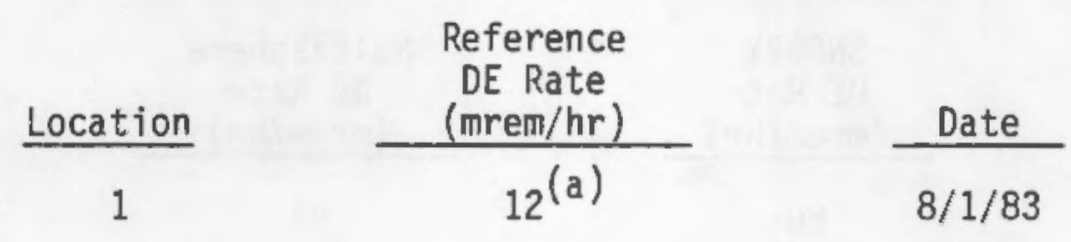

Site Equivalent

Diameter

TEPC \# (micrometers)

TEPC Diameter

$(\mathrm{cm})$

Live Time

1.0

12.7

(sec)

1800

Absorbed

Dose Rate (mrad/hr)

$1.4 \pm 0.27^{(b)}$
Kellerer Approximation $\begin{array}{cc}\begin{array}{l}\text { Average } \\ \text { Quality }\end{array} & \begin{array}{c}\text { Dose Equivalent } \\ \text { Rate } \\ \text { Factor }\end{array} \\ & \end{array}$

1.9

3

2.5

Borak Approximation

\begin{tabular}{cc}
$\begin{array}{l}\text { Average } \\
\text { Quality }\end{array}$ & Dose Equivalent \\
Rate \\
Factor & (mrem/hr) \\
\hline
\end{tabular}

4

Total

Proton Drop

Point

Channel \#

216

\begin{tabular}{c} 
Calibration \\
Constant \\
(keV/micron/channel) \\
\hline
\end{tabular}

Total

Neutron Events

Neutron Dose Events

0.4607

(Counts)

$8.05 \times 10^{4}$

(Counts $\times$ Channel)

$8.24 \times 10^{5}$

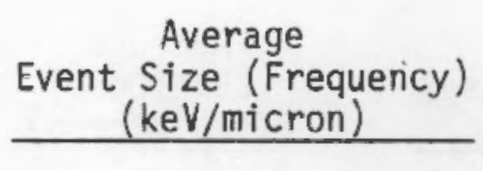

4.7

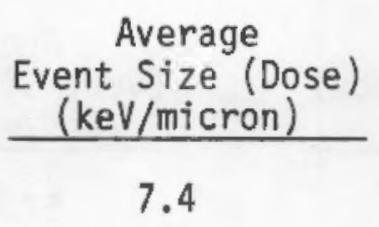

7.4
Average LET (Oose) (keV/micron)

6.6

(a) Portable ion chamber.

(b) One standard deviation from Poisson statistics. 


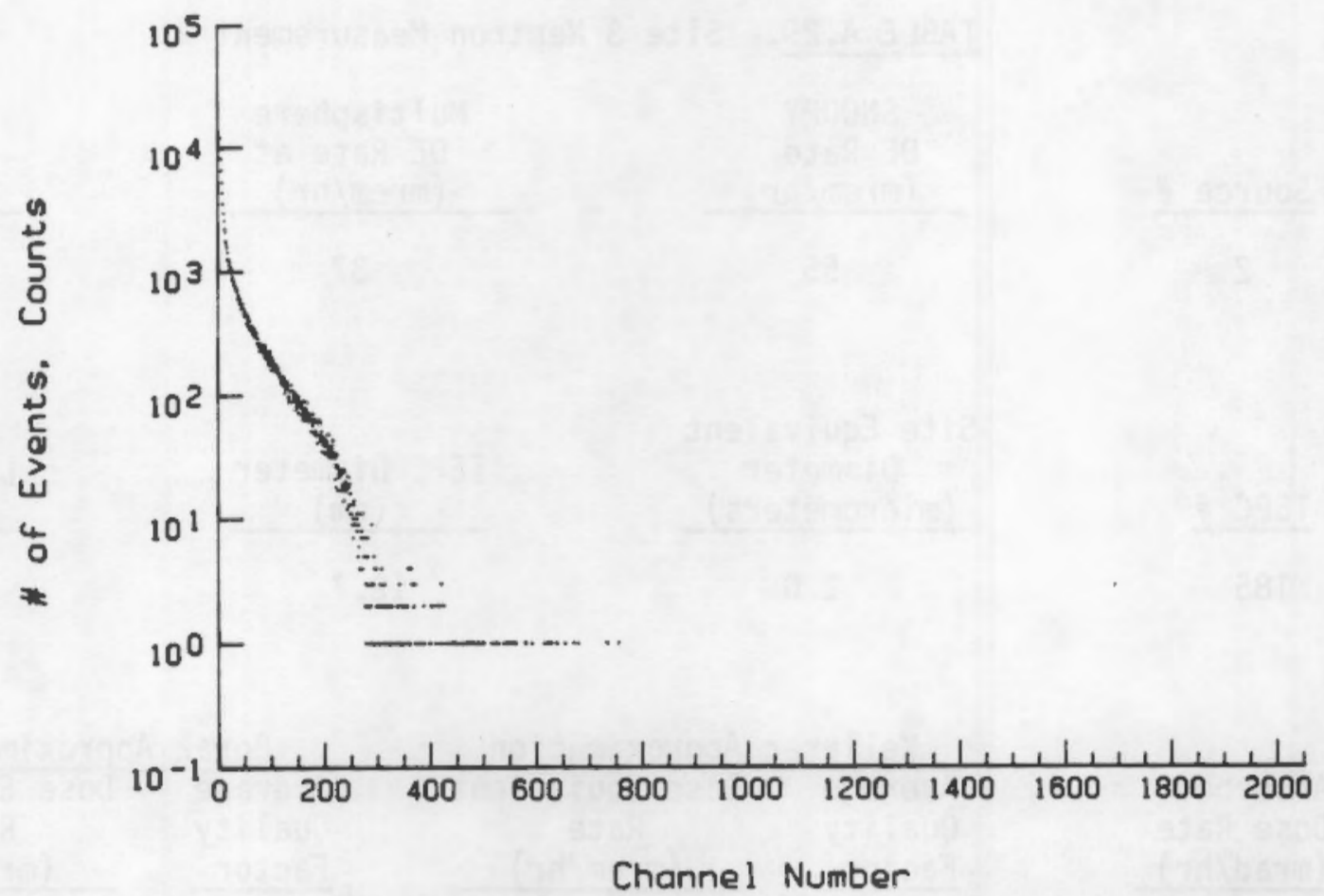

FIGURE A.33. Raw Data for Site 3 - Location 1

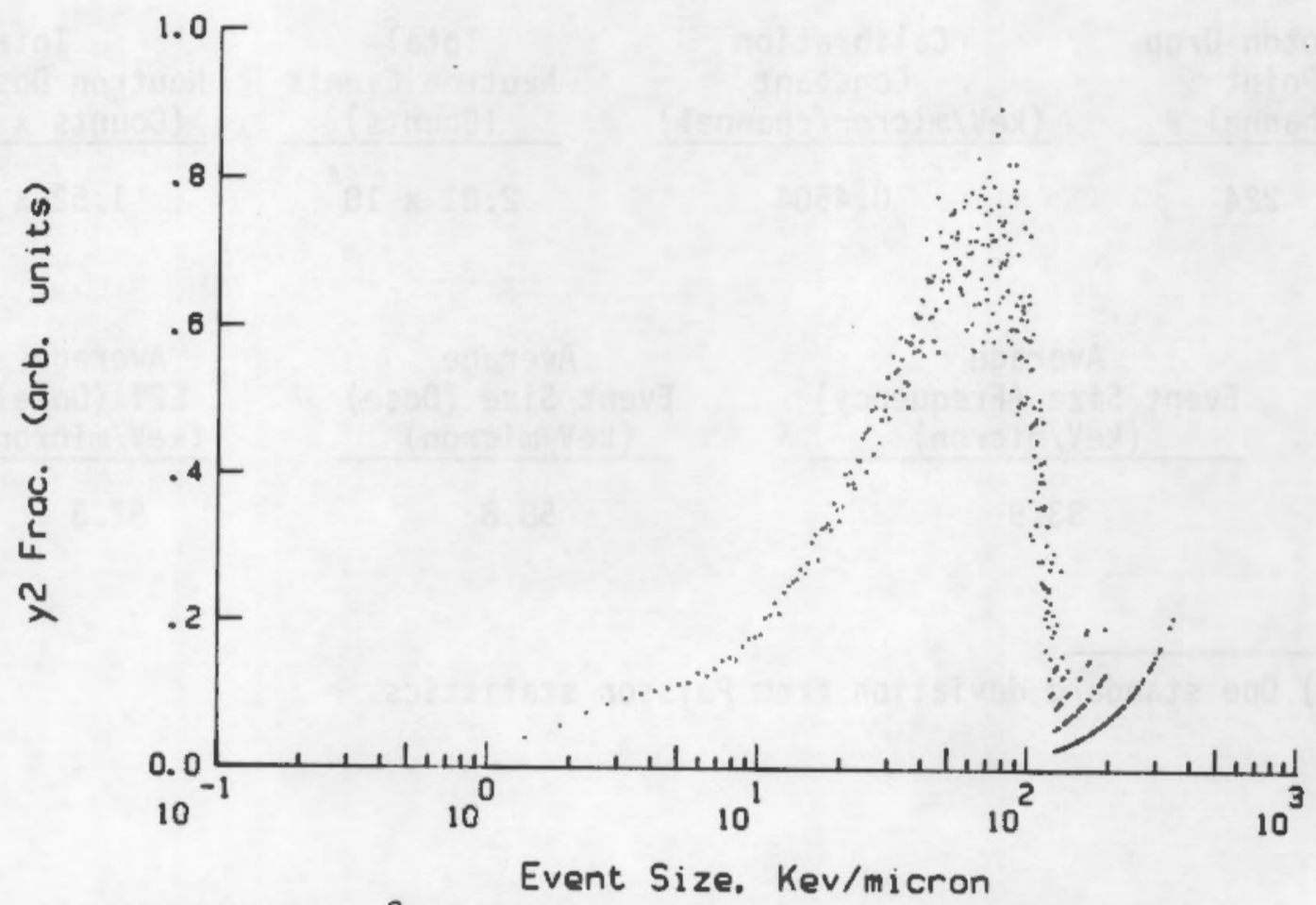

FIGURE A.34. $Y^{2}$ Distribution for Site 3 - Location 1 
TABLE A.29. Site 3 Neutron Measurement 2

\begin{tabular}{|c|c|c|c|}
\hline Source \# & $\begin{array}{l}\text { SNOOPY } \\
\text { DE Rate } \\
\text { (mrem/hr) }\end{array}$ & $\begin{array}{c}\text { Multisphere } \\
\text { DE Rate at } \\
\text { (mrem/hr) }\end{array}$ & Date \\
\hline 2 & 55 & 37 & $8 / 1 / 83$ \\
\hline
\end{tabular}

\begin{tabular}{|c|c|c|c|}
\hline TEPC \# & $\begin{array}{c}\text { Site Equivalent } \\
\text { Diameter } \\
\text { (micrometers) } \\
\end{array}$ & $\begin{array}{c}\text { TEPC Diameter } \\
(\mathrm{cm}) \\
\end{array}$ & $\begin{array}{c}\text { Live Time } \\
(\mathrm{sec})\end{array}$ \\
\hline 185 & 1.0 & 12.7 & 1800 \\
\hline
\end{tabular}

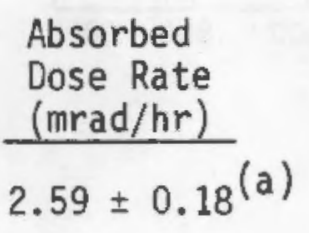

Kellerer Approximation

$\begin{array}{cc}\begin{array}{l}\text { Average } \\ \text { Quality }\end{array} & \text { Dose Equivalent } \\ \text { Factor } & \text { Rate } \\ \text { (mrem/hr) }\end{array}$

9.9

26
Borak Approximation

\begin{tabular}{cc}
$\begin{array}{c}\text { Average } \\
\text { Quality }\end{array}$ & Dose Equivalent \\
Rate \\
Factor & (mrem/hr) \\
\hline
\end{tabular}

11.3 \begin{tabular}{l} 
Proton Drop \\
Point \\
Channel \# \\
\hline
\end{tabular}

224

$\begin{gathered}\text { Calibration } \\ \text { Constant } \\ (\mathrm{keV} / \mathrm{micron} / \text { channel) }\end{gathered}$
0.4504

Constant

0.4504

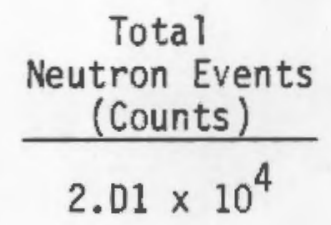

Average

Event Size (Dose)

(keV/micron)

58.8
Total Neutron Dose Events (Counts $\times$ Channel)

$1.52 \times 10^{6}$

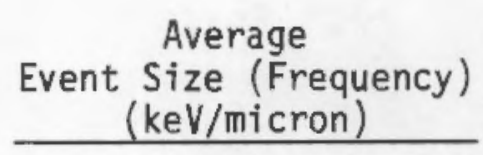

33.9
Average

LET (Dose)

(keV/micron)

52.3

(a) One standard deviation from Poisson statistics. 
TABLE A.30. Site 3 Gamma Measurement 2

Location $\frac{1}{2} \quad \frac{\begin{array}{c}\text { Reference } \\ \text { DE Rate } \\ \text { (mrem/hr) }\end{array}}{50^{(a)}} \quad \frac{\text { Date }}{8 / 1 / 83}$

TEPC \#

185 $\begin{gathered}\text { Absorbed } \\ \text { Dose Rate } \\ \text { (mrad/hr) }\end{gathered}$
$1.0 \pm 0.25^{(\mathrm{b})}$

\begin{tabular}{l} 
Proton Drop \\
Point \\
Channel \# \\
\hline
\end{tabular}

224

\author{
Calibration \\ Constant \\ (keV/micron/channel)
}

0.4504
TEPC Diameter

(cm)

12.7
Live Time (sec)

1800
Kellerer Approximation

\begin{tabular}{cc}
$\begin{array}{l}\text { Average } \\
\text { Quality }\end{array}$ & $\begin{array}{c}\text { Dose Equivalent } \\
\text { Rate } \\
\text { (mrem/hr) }\end{array}$ \\
\hline Factor &
\end{tabular}

1.2

1
Borak Approximation

\begin{tabular}{cc}
$\begin{array}{c}\text { Average } \\
\text { Quality }\end{array}$ & $\begin{array}{c}\text { Dose Equivalent } \\
\text { Rate } \\
\text { (mrem/hr) }\end{array}$ \\
\hline
\end{tabular}

1.7
Average

Event Size (Frequency)

( $\mathrm{keV} /$ micron)

3.2
Average

Event Size (Dose)

(keV/micron)

4.3
Total Neutron Events Neutron Dose Events (Counts) (Counts $\times$ Channel)

$8.24 \times 10^{4}$

$5.82 \times 10^{5}$

(a) Portable ion chamber.

(b) One standard deviation from Poisson statistics. 


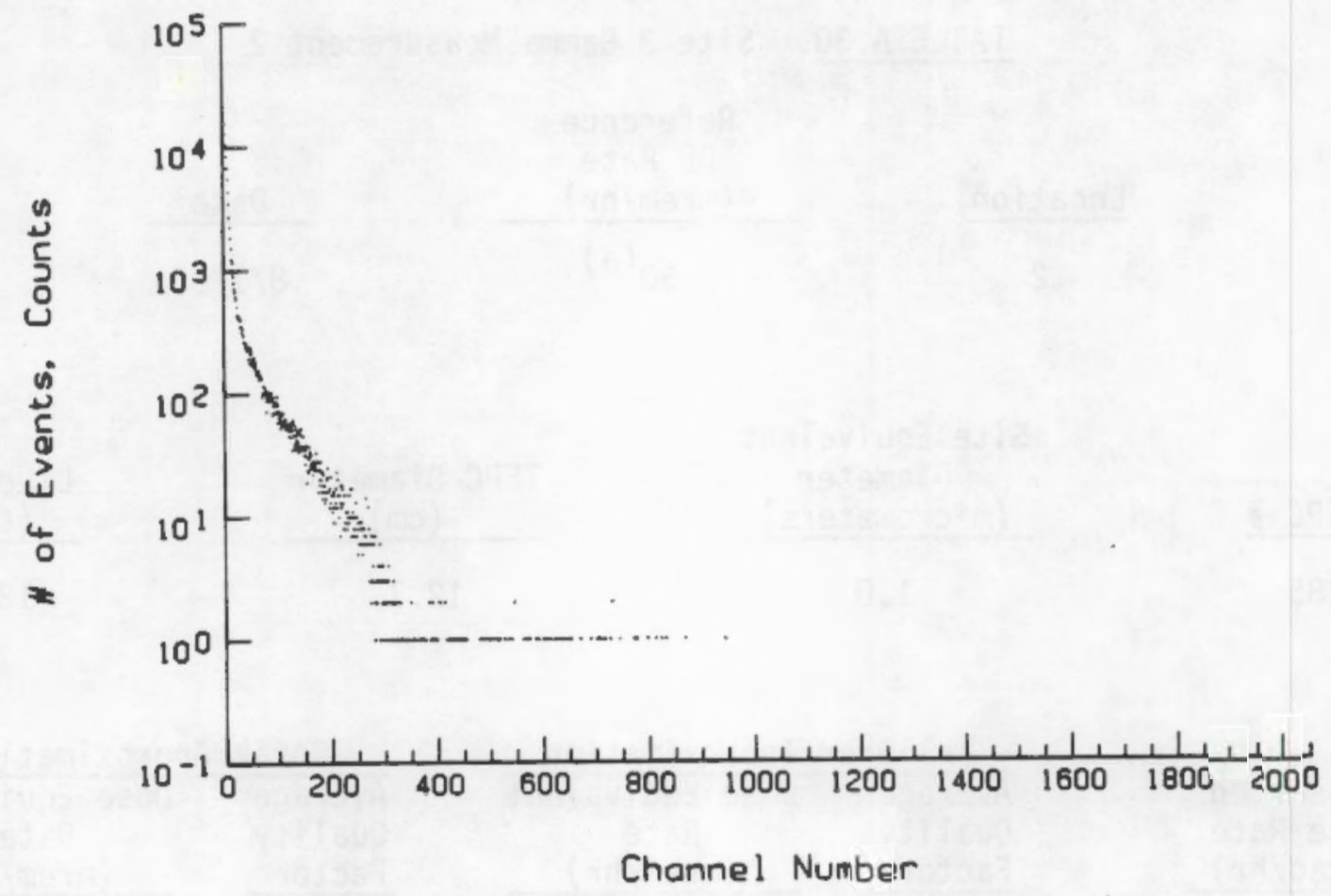

FIGURE A.35. Raw Data for Site 3 - Location 2

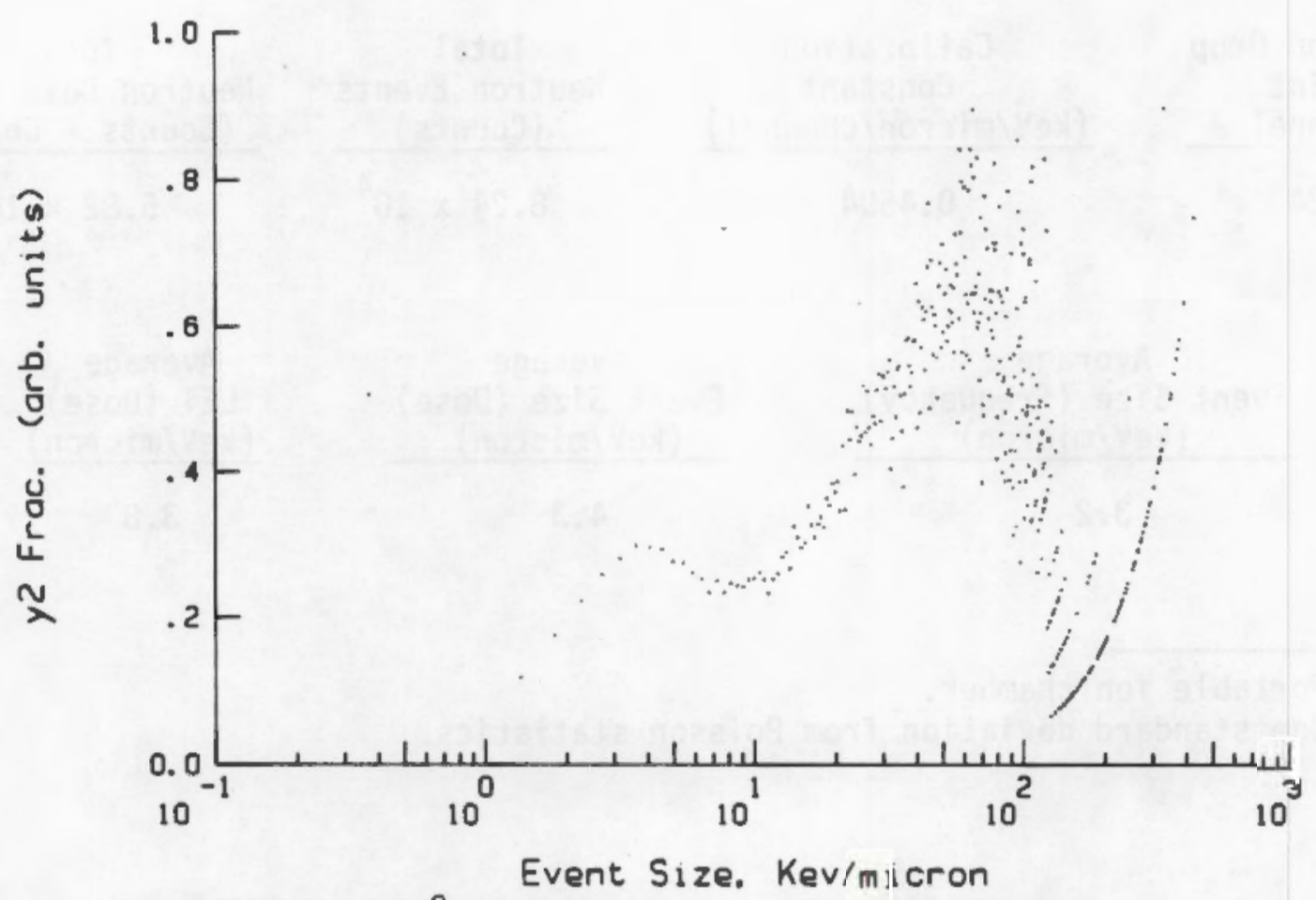

FIGURE A.36. $Y^{2}$ Distribution for Site 3 - Location 2 
TABLE A.31. Si te 4 (PWR) Neutron Measurement 1

\begin{tabular}{|c|c|c|c|}
\hline Location & $\begin{array}{c}\text { SNOOPY } \\
(\min / \mathrm{hr})\end{array}$ & $\begin{array}{c}\text { Reference } \\
\text { DE Rate } \\
\text { (mrem/hr) }\end{array}$ & Date \\
\hline 1 & 27 & 17 & $8 / 18 / 83$ \\
\hline TEPC \# & $\begin{array}{c}\text { Site Equivalent } \\
\text { Diameter } \\
\text { (micrometers) }\end{array}$ & $\begin{array}{l}\text { TEPC Diameter } \\
(\mathrm{cm}) \\
\end{array}$ & $\begin{array}{l}\text { Live Time } \\
(\mathrm{sec}) \\
\end{array}$ \\
\hline 185 & 2.0 & 12.7 & 13096 \\
\hline
\end{tabular}

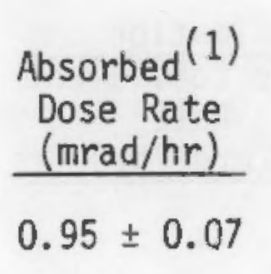

Proton Drop

Point

Channel \#

258
Kellerer Approximation

\begin{tabular}{cc}
$\begin{array}{c}\text { Average } \\
\text { Quality }\end{array}$ & $\begin{array}{c}\text { Equivalent } \\
\text { Rate } \\
\text { (mrem } / \mathrm{hr} \text { ) }\end{array}$ \\
\hline
\end{tabular}

8.4

8
Borak Approximation \begin{tabular}{cc}
$\begin{array}{l}\text { Average } \\
\text { Quality }\end{array}$ & Dose Equivalent \\
Rate \\
Factor & (mrem/hr) \\
\hline
\end{tabular}

10.5

10
Average

Event Size (Frequency) (keV/micron)

32.5
Calibration

Constant

(keV/micron/channel)

0.0310

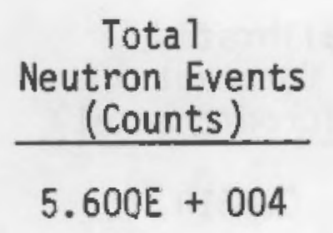

Total
$\begin{gathered}\text { Neutron Dose Events } \\ \text { (Counts } \times \text { Channel) }\end{gathered}$
$4.792 E+006$

(1) One standard deviation from Poisson Statistics. 
TABLE A.32. Site 4 (PWR) Gamma Measurement 1

Reference

DE Rate

Location

(mrem/hr)

Date

1

0

$8 / 18 / 83$

TEPC \#

185

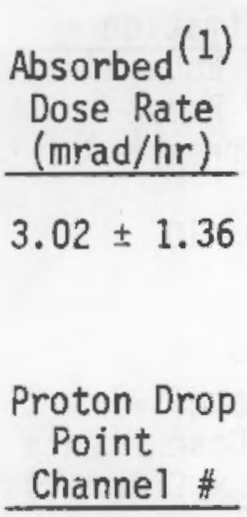

258
Kellerer Approximation

\begin{tabular}{lc}
$\begin{array}{l}\text { Average } \\
\text { Quality }\end{array}$ & $\begin{array}{c}\text { Dose Equivalent } \\
\text { Rate } \\
\text { Factor }\end{array}$ \\
\hline
\end{tabular}

1.0

Calibration

Constant

(keV/micron/channel)

0.0310

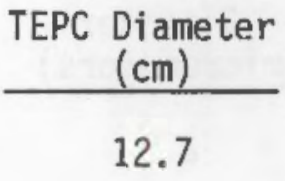

Live Time (sec)

13096
Borak Approximation Average Dose EquivaTent Quality Rate Factor (mrem/hr)

1.4

4
Average

Event Size (Frequency) ( $\mathrm{keV} / \mathrm{micron})$

3.3
Average Event Size (Dose) (keV/micron)

3.6
Tota! Neutron Dose Events (Counts $x$ Channel)

1.527E+007

(1) One standard deviation from Poisson Statistics. 


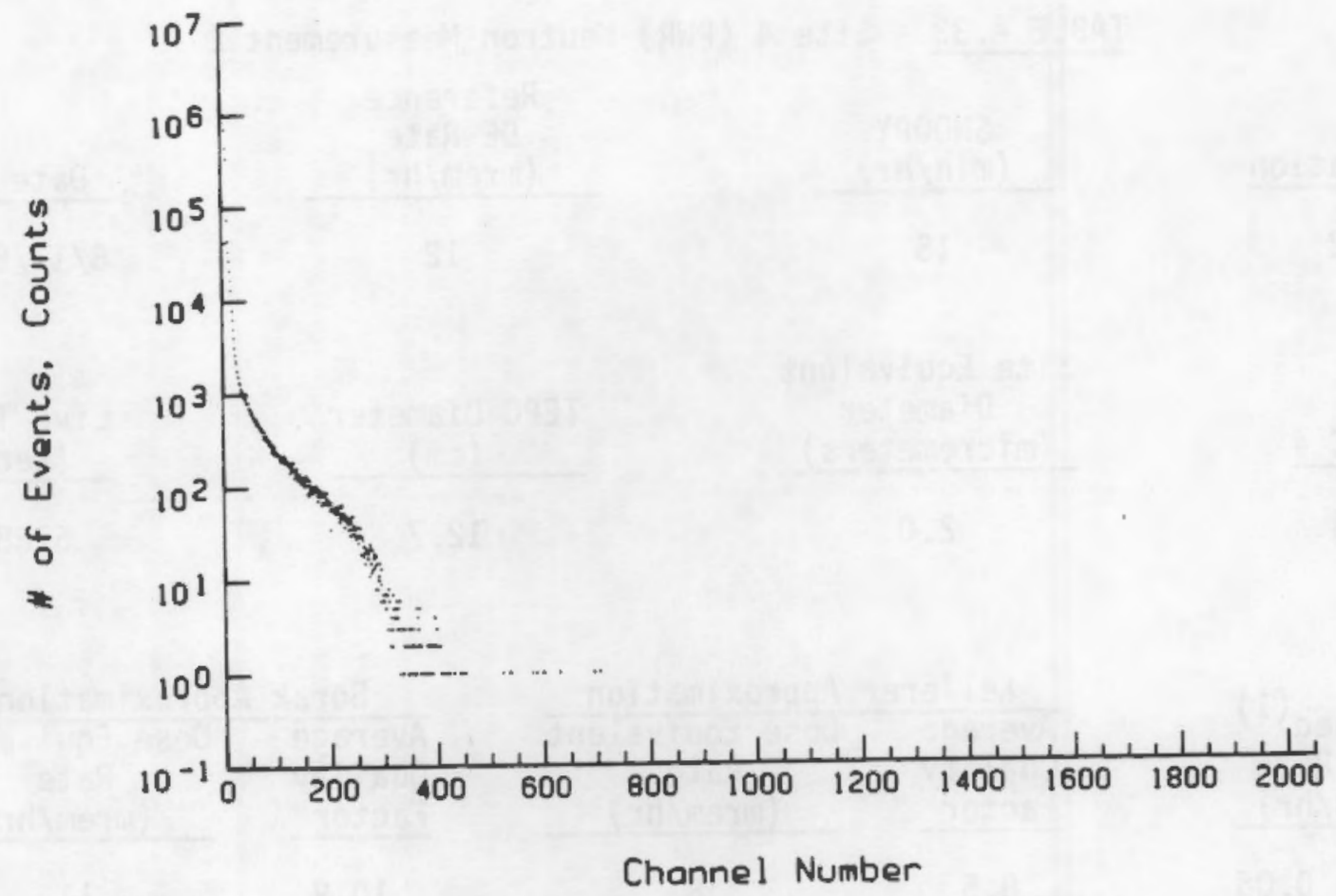

FIGURE A.37. Raw Data for Site 4 - Location 1 Neutron Measurement

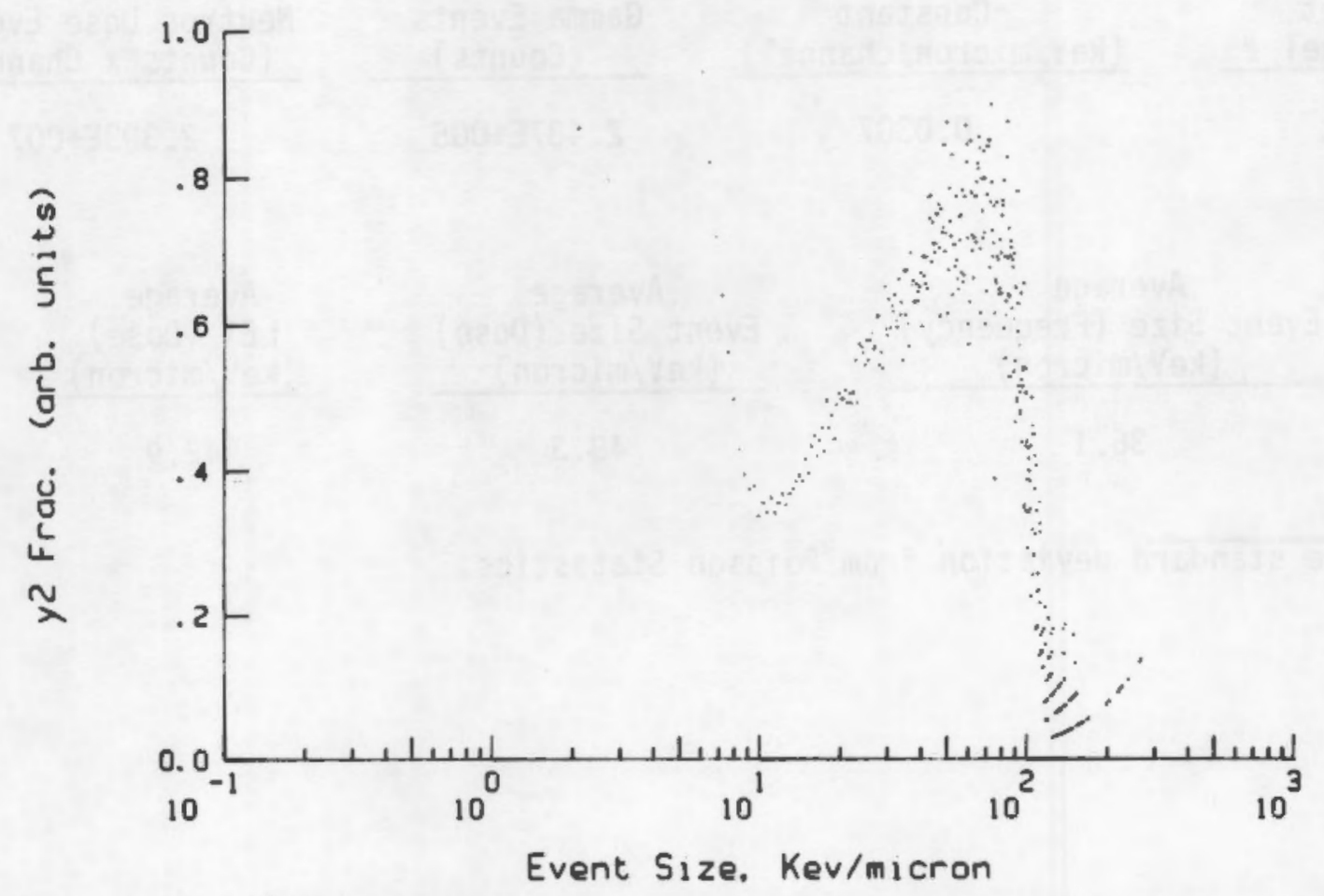

FIGURE A.38. $y^{2}$ Distribution for Site 4 - Location 1 Neutron Measurement 
TABLE A.33. Site 4 (PWR) Neutron Measurement 2

\begin{tabular}{|c|c|c|c|}
\hline Location & $\begin{array}{c}\text { SNOOPY } \\
(\min / \mathrm{hr})\end{array}$ & $\begin{array}{c}\text { Reference } \\
\text { DE Rate } \\
\text { (mrem/hr) } \\
\end{array}$ & Date \\
\hline 2 & 15 & 12 & $8 / 17 / 83$ \\
\hline TEPC \# & $\begin{array}{c}\text { Site Equivalent } \\
\text { Diameter } \\
\text { (micrometers) } \\
\end{array}$ & $\begin{array}{l}\text { TEPC Diameter } \\
(\mathrm{cm}) \\
\end{array}$ & $\begin{array}{l}\text { Live Time } \\
(\mathrm{sec}) \\
\end{array}$ \\
\hline 185 & 2.0 & 12.7 & 67882 \\
\hline
\end{tabular}

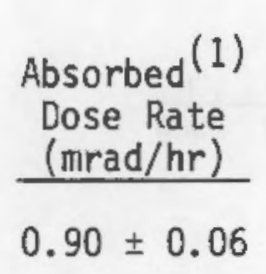

Proton Drop Point Channel \#

261
Kellerer Approximation \begin{tabular}{cc}
$\begin{array}{c}\text { Average } \\
\text { Quality }\end{array}$ & $\begin{array}{c}\text { Dose Equivalent } \\
\text { Rate } \\
\text { (mrem/hr) }\end{array}$ \\
\hline Factor &
\end{tabular}

8.5

8

Borak Approximation \begin{tabular}{cc}
$\begin{array}{c}\text { Average } \\
\text { Quality }\end{array}$ & $\begin{array}{c}\text { Dose Equivalent } \\
\text { Rate } \\
\text { (mrem/hr) }\end{array}$ \\
\hline Factor &
\end{tabular}

10.8

11

Average

Event Size (Frequency)

(keV/micron)

36.1
Calibration Constant (keV/micron/channe1)

0.0307
Tota 1 Gamma Events (Counts)

$2.487 E+005$
Total Neutron Dose Events (Counts $\times$ Channel)

2. $393 \mathrm{E}+007$

(1) One standard deviation from Poisson Statistics. 
TABLE A.34. Site 4 (PWR) Gamma Measurement 2

Location

2

TEPC \#

185

Absorbed (1)

Dose Rate

(mrad/hr)

$3.57 \pm 1.09$
Kellerer Approximation Average Dose Equivalent Quality

Factor

1.8

Calibration

Constant

Point

Channel \#

261

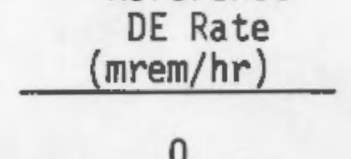

0
Date

$8 / 17 / 83$
Si te Equivalent Diameter

2.0
TEPC Diameter (cm)

12.7
Live Time (sec)

67882

$\begin{array}{ccccc}\begin{array}{c}\text { Proton Drop } \\ \text { Point } \\ \text { Channel \# }\end{array} & \frac{\begin{array}{c}\text { Calibration } \\ \text { Constant } \\ \text { (keV/micron/channel) }\end{array}}{261} & \frac{\begin{array}{c}\text { Total } \\ \text { Gamma Events } \\ \text { (Counts) }\end{array}}{5.0307} & & \begin{array}{c}\text { Notal } \\ \text { (Counts x X Channel) }\end{array} \\ & 0.622 \mathrm{E}+006 & & 9.438 \mathrm{E}+007\end{array}$

Average

Event Size (Frequency) (keV/micron)

\section{3}

Average

Event Size (Dose) (keV/micron)

6.7
Borak Approximation

\begin{tabular}{lc}
$\begin{array}{l}\text { Average } \\
\text { Quality }\end{array}$ & $\begin{array}{c}\text { Dose Equivalent } \\
\text { Rate } \\
\text { Factor }\end{array}$ \\
\hline
\end{tabular}

2.3

8 


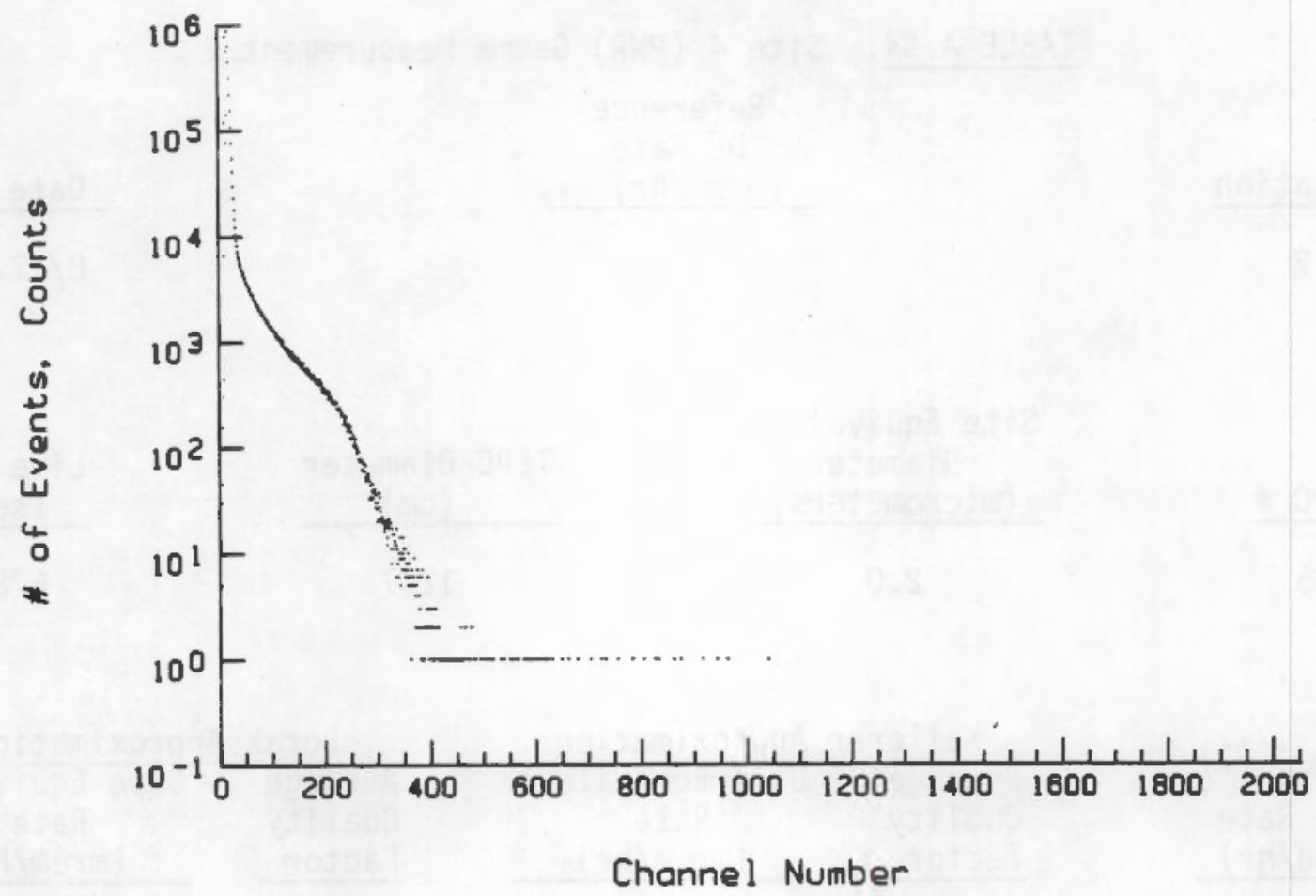

FIGURE A.39. Raw Data for Site 4 - Location 2 Neutron Measurement

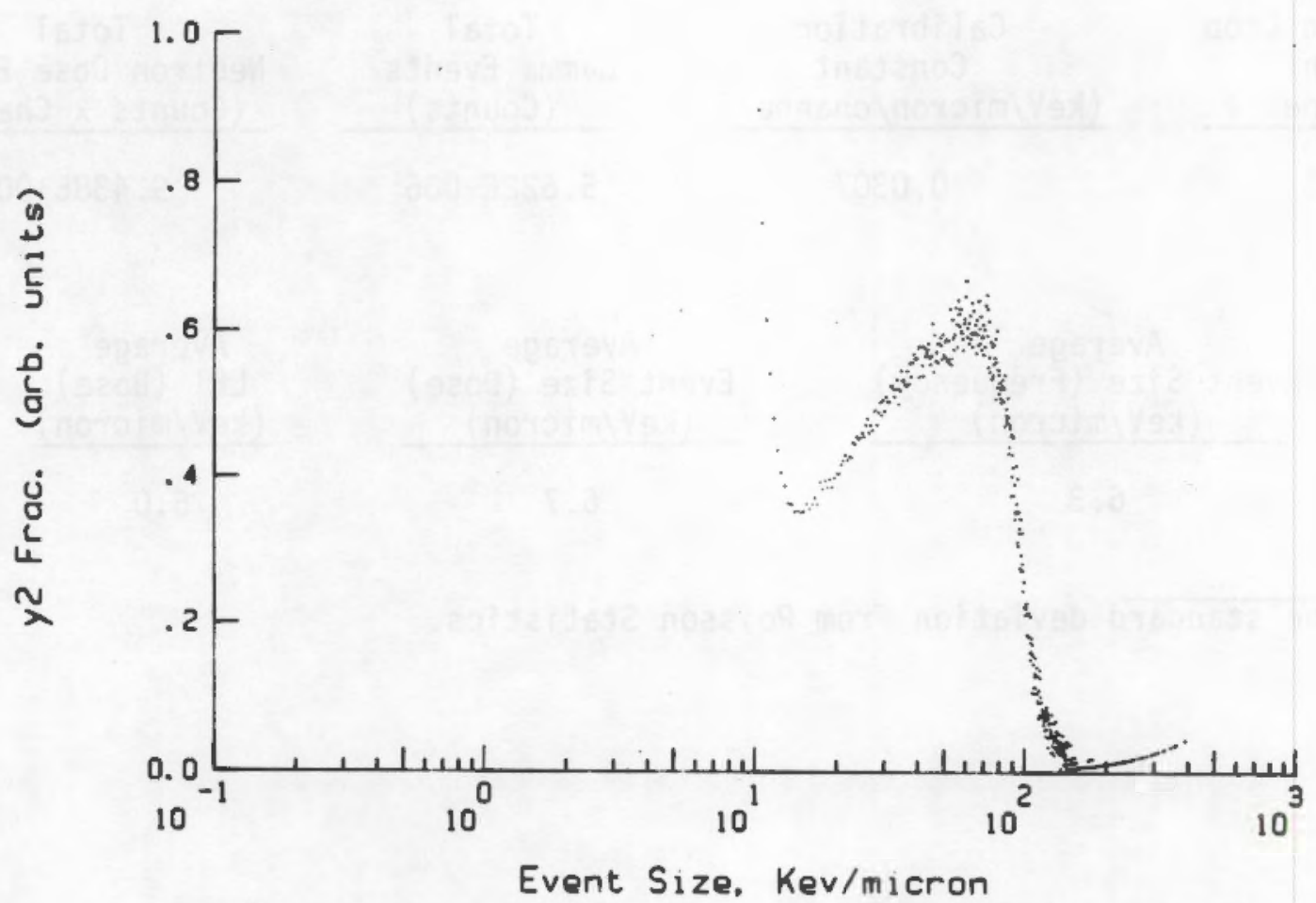

FIGURE A.40. $Y^{2}$ Distribution for Site 4 - Location 2 Neutron Measurement 
TABLE A.35. Si te 4 (PWR) Ganma Measurement 3

Location

3
Reference

DE Rate

(mrem/hr)

0
Date

$8 / 15 / 83$
Site Equivalent

Diameter

$\underline{\text { TEPC \# }}$

185 (micrometers)

2.0
TEPC Diameter

(cm)

12.7
Live Time

(sec)

4415

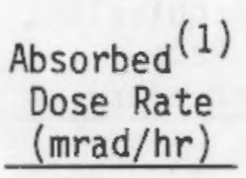

$8.27 \pm 4.24$

Proton Drop

Point

Channel \#

257
Kellerer Approximation

\begin{tabular}{c}
$\begin{array}{c}\text { Average } \\
\text { Quality }\end{array}$ \\
$\begin{array}{c}\text { Dose Equivalent } \\
\text { Rate } \\
\text { Factor }\end{array}$ \\
\hline
\end{tabular}

1.8

8
Borak Approximation

$\begin{array}{cc}\begin{array}{l}\text { Average } \\ \text { Quality }\end{array} & \begin{array}{c}\text { Dose Equivalent } \\ \text { Rate } \\ \text { Factor }\end{array} \\ \text { (mrem/hr) }\end{array}$

1.2

10
Average

Event Size (Frequency) (keV/micron)

\section{7}

Calibration

Constant

(keV/micron/channel)

0.0311
Total

Gamma Events

(Counts)

$1.954 \mathrm{E}+006$
Total Neutron Dose Events (Counts $\times$ Channel)

$1.403 \mathrm{E}+007$

(1) One standard deviation from Poisson Statistics. 
TABLE A.36. Site 4 (PWR) Neutron Measurement 3

Location $3 \frac{\begin{array}{c}\text { SNOOPY } \\ (\mathrm{min} / \mathrm{hr})\end{array}}{33} \quad \frac{\begin{array}{c}\text { Reference } \\ \text { DE Rate } \\ \text { (mrem/hr) }\end{array}}{16} \quad \frac{\text { Date }}{8 / 15 / 83}$

TEPC \# $\quad \begin{gathered}\text { Diameter } \\ \text { (micrometers) }\end{gathered}$ 185

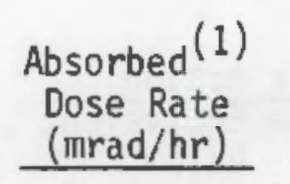

$1.28 \pm 0.09$

Proton Drop

Point Channel \#

257
Calibration Constant (keV/micron/channe1)

D.0311
Kellerer Approximation

\begin{tabular}{cc}
\hline Average & Dose Equivalent \\
Quality & Rate \\
(mrem/hr) \\
Factor
\end{tabular}

$8.2 \quad 11$

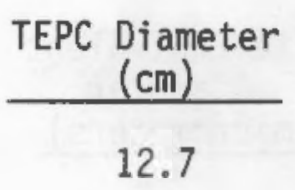

Live Time (sec)

4415
Borak Approximation

\begin{tabular}{c}
$\begin{array}{c}\text { Average } \\
\text { Quality }\end{array}$ \\
Factor \\
Fate \\
\hline
\end{tabular}

10.3

13

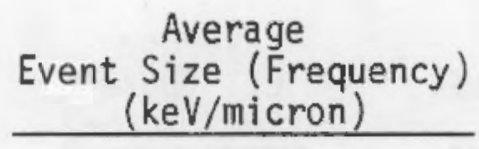

31.0

$\frac{\begin{array}{c}\text { Total } \\ \text { Gamma Events } \\ \text { (Counts) }\end{array}}{2.666 \mathrm{E}+004}$

Average Event Size (Dose) (keV/micron)

46.4
Tota 1 Neutron Dose Events (Counts $\times$ Channel)

2.167E+006

(1) One standard deviation from Poisson Statistics. 


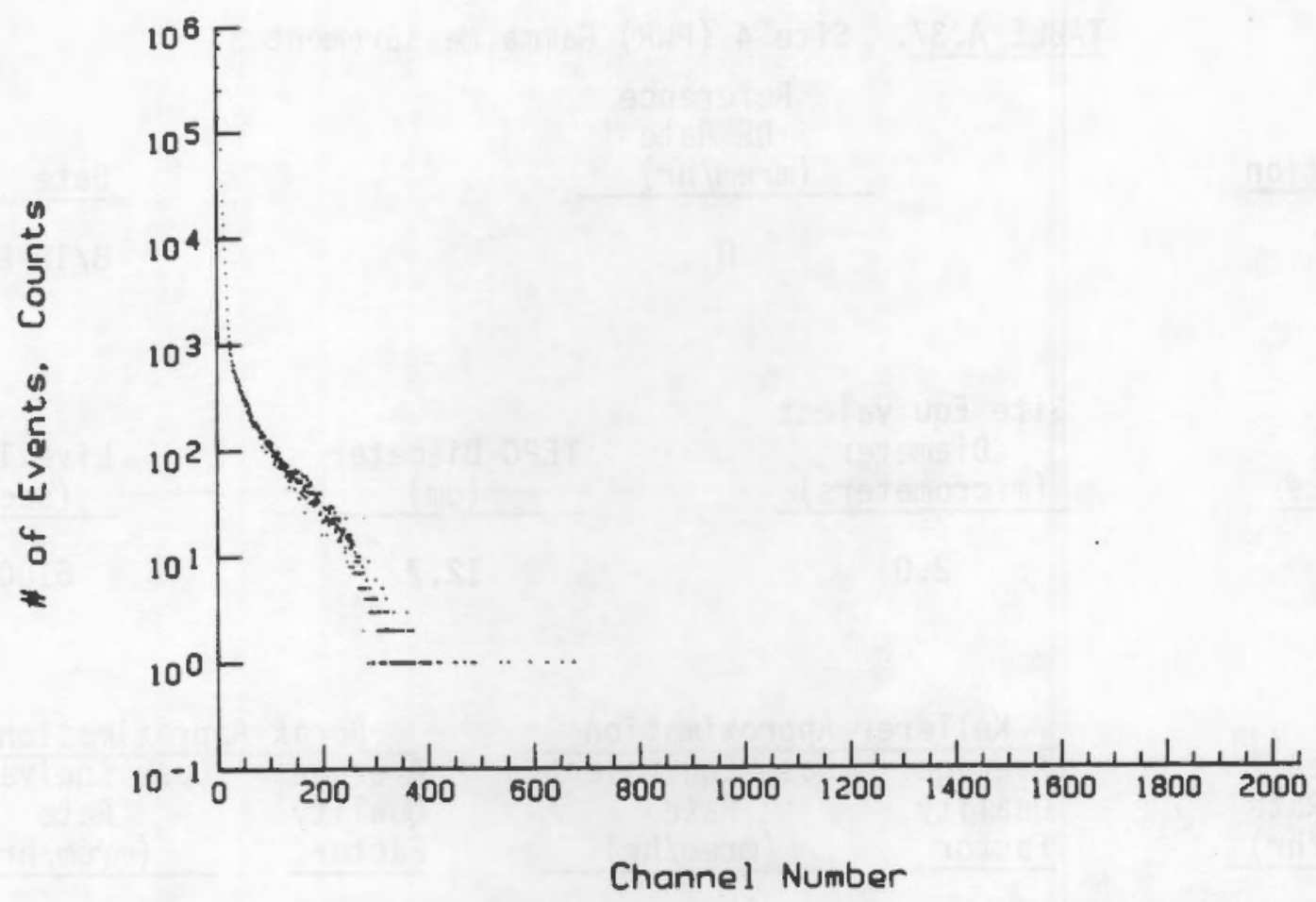

FIGURE A.41. Raw Data for Site 4 - Location 3 Neutron Measurement

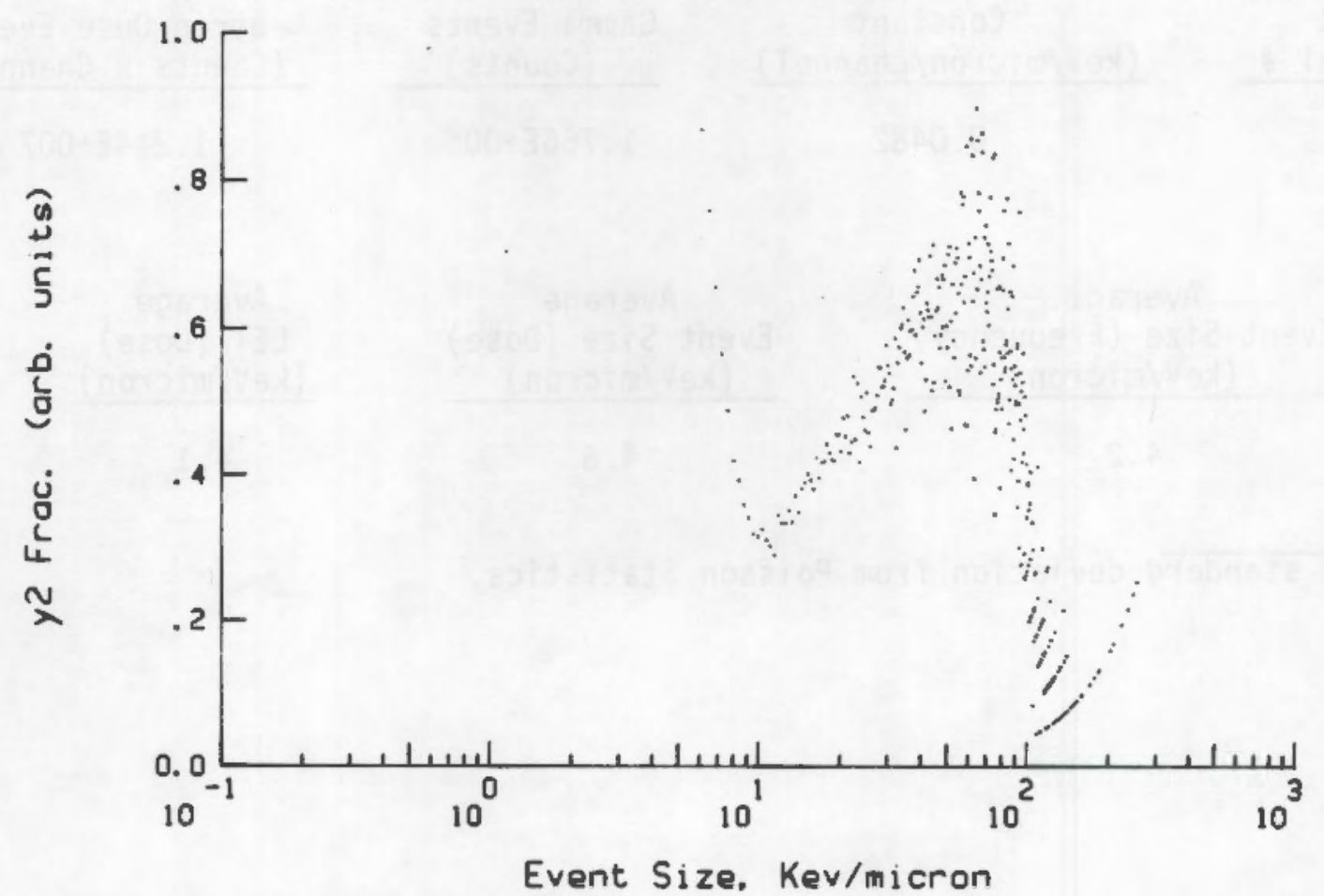

FIGURE A.42. $Y^{2}$ Distribution for Site 4 - Location 3 Neutron Measurement 
TABLE A.37. Site 4 (PWR) Gamma Measurement 3

Reference

DE Rate

Location

(mrem/hr)

Date

4

0

$8 / 16 / 83$

Site Equivalent

$$
\text { Diameter }
$$

$\underline{\text { TEPC \# }}$

(micrometers)

TEPC Diameter

Live Time

185

2.0

$(\mathrm{cm})$ (sec)

12.7

6100

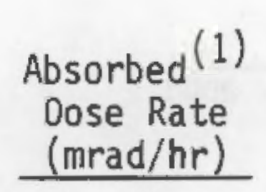

$8.22 \pm 4.23$

Proton Drop

Point

Channel \#

166
Kellerer Approximation

\begin{tabular}{|c|c|}
\hline $\begin{array}{l}\text { Average } \\
\text { Quality } \\
\text { Factor }\end{array}$ & $\begin{array}{c}\text { Dose Equivalent } \\
\text { Rate } \\
\text { (mrem/hr) }\end{array}$ \\
\hline
\end{tabular}

1.3

Calibration

Constant

(keV/micron/channel)

0.0482

11
Borak Approximation

\begin{tabular}{cc}
\hline $\begin{array}{c}\text { Average } \\
\text { Quality }\end{array}$ & $\begin{array}{c}\text { Dose Equivalent } \\
\text { Rate } \\
\text { (mrem/hr) }\end{array}$ \\
\hline
\end{tabular}

1.8

15
Average

Event Size (Frequency)

(keV/micron)

4.2
Tota 1 Ganma Events (Counts)

$1.756 \mathrm{E}+006$
Total Neutron Dose Events (Counts $\times$ Channel)

$1.244 \mathrm{E}+007$

(1) One standard deviation from Poisson Statistics. 
TABLE A.38. Site 4 (PWR) Neutron Measurement 4

Location

4

$\underline{\text { TEPC \# }}$

185

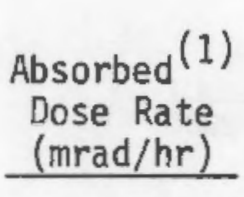

$2.99 \pm 0.23$

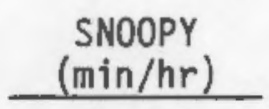

68

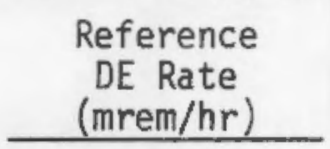

35
Date

$8 / 16 / 83$

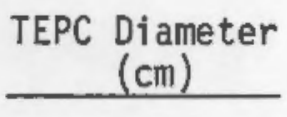

12.7
Live Time (sec)

6100
Site Equivalent
Diameter (micrometers)

2.0
Kellerer Approximation

\begin{tabular}{cc}
$\begin{array}{c}\text { Average } \\
\text { Quality }\end{array}$ & $\begin{array}{c}\text { Dose Equivalent } \\
\text { Rate } \\
\text { (mrem/hr) }\end{array}$ \\
\hline Factor &
\end{tabular}

9.6

29
Borak Approximation \begin{tabular}{cc}
$\begin{array}{c}\text { Average } \\
\text { Quality }\end{array}$ & $\begin{array}{c}\text { Dose Equivalent } \\
\text { Rate } \\
\text { (mrem/hr) }\end{array}$ \\
\hline
\end{tabular}

11.7

35 \begin{tabular}{l} 
Proton Drop \\
Point \\
Channel \# \\
\hline
\end{tabular}

166

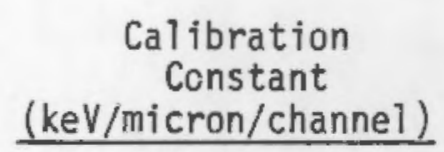

0.0482

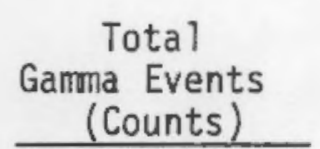

$7.073+004$
Total Neutron Dose Events (Counts $\times$ Channel)

$4.526 \mathrm{E}+006$
Average

Event Size (Frequency) (keV/micron)

37.8
Average Event Size (Dose) (keV/micron)

56.8
Average LET (Dose) (keV/micron)

50.5

(1) One standard deviation from Poisson Statistics. 


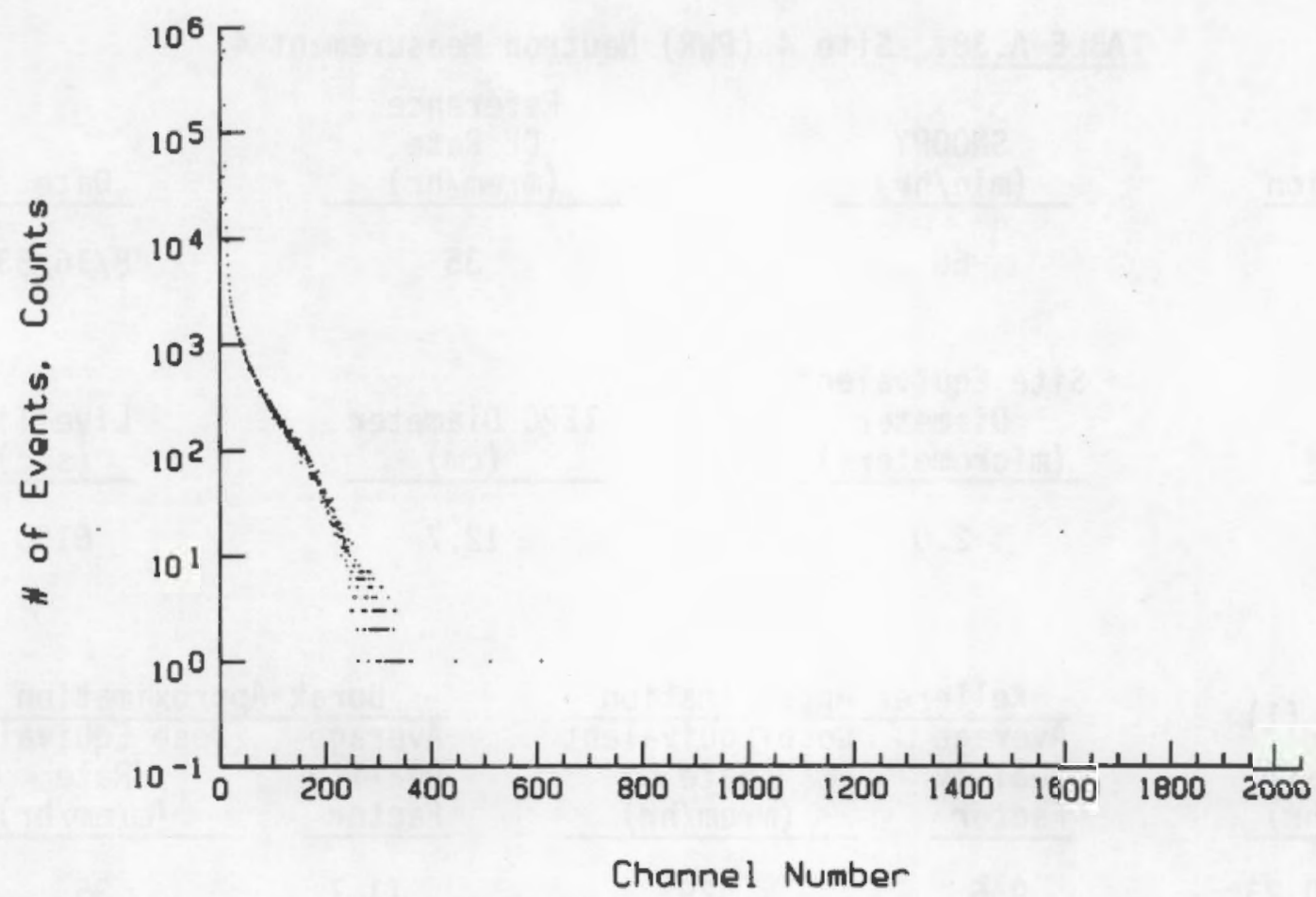

FIGURE A.43. Raw Data for Site 4 - Location 4 Neutron Measurement

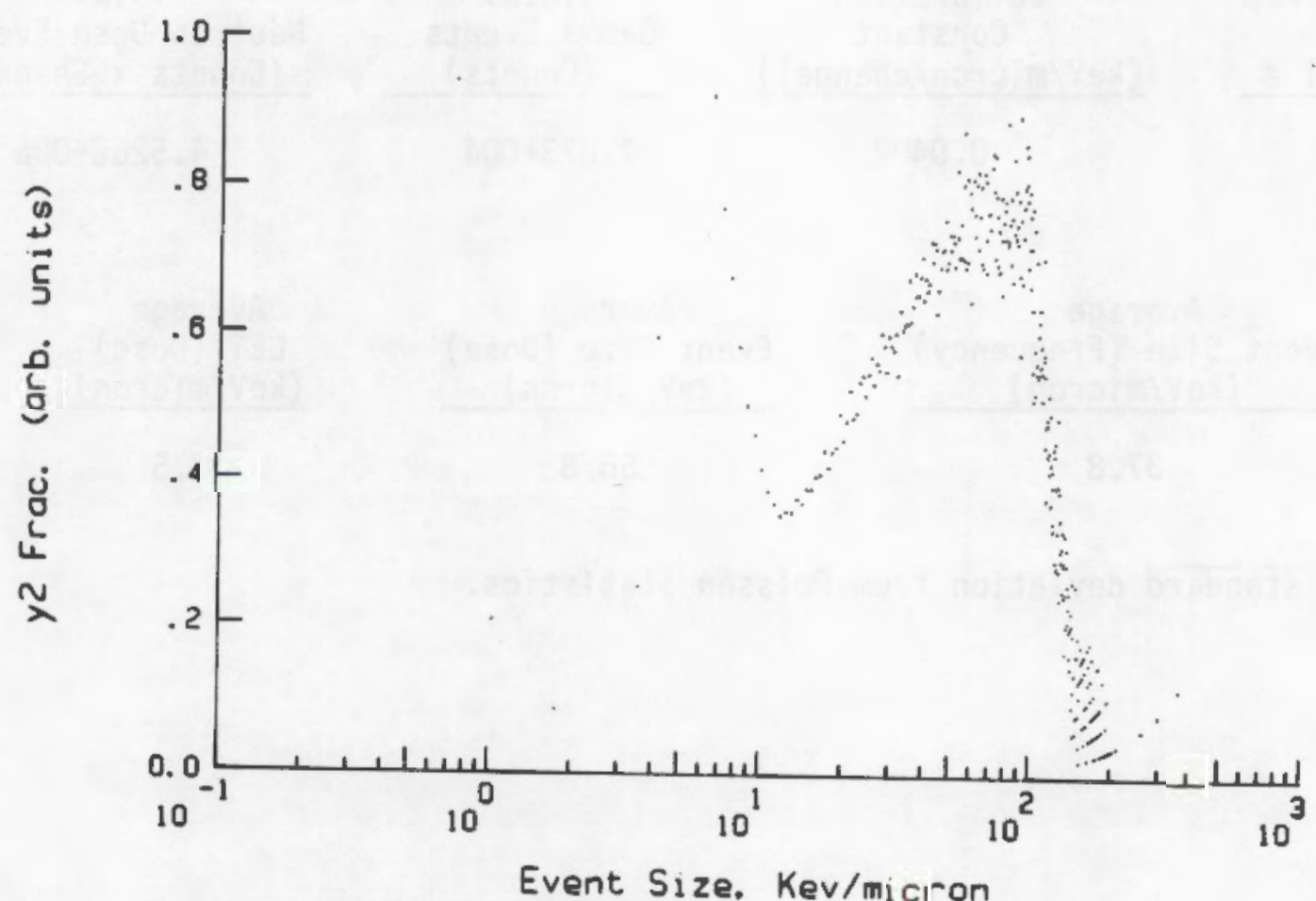

FIGURE A.44. $Y^{2}$ Distribution for Site 4 - Location 4 Neutron Measurement 
TABLE A.39. Site 4 (PWR) Gamma Measurement 3

Reference

DE Rate

Location

(mrem/hr)

Date

5

0

$8 / 17 / 83$

TEPC \#

Site Equivalent
Diameter

(micrometers)

TEPC Diameter

Live Time

(cm)

(sec)

185

2.0

12.7

59151

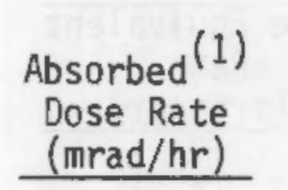

$1.95 \pm 0.67$

Proton Drop

Point

Channel \#

205
Kellerer Approximation

\begin{tabular}{lc}
\hline Average & Dose Equivalent \\
Quality & Rate \\
Factor & (mrem/hr) \\
\hline
\end{tabular}

1.3

Calibration

Constant

(keV/micron/channel)

0.0390
Total Gamma Events (Counts)

$4.205 E+006$
Borak Approximation

\begin{tabular}{lc}
\hline Average & Dose Equivalent \\
Quality & Rate \\
Factor & (mrem $/ \mathrm{hr}$ ) \\
\hline
\end{tabular}

1.8

4
Average

Event Size (Frequency)

(keV/micron)

$$
4.0
$$

Average

Event Size (Dose) (keV/micron)

4.7
Total Neutron Dose Events (Counts $\times$ Channel)

3. $540 \mathrm{E}+007 \mathrm{E}$

(1) One standard deviation from Poisson Statistics. 
TABLE A.40. Site 4 (PWR) Neutron Measurement 5

Location $\quad \frac{\begin{array}{c}\text { SNOOPY } \\ (\mathrm{min} / \mathrm{hr})\end{array}}{53} \quad \frac{\begin{array}{c}\text { Reference } \\ \text { DE Rate } \\ \text { (mrem/hr) }\end{array}}{16} \quad \frac{\text { Date }}{8 / 17 / 83}$
Site Equivalent
Diameter
(micrometers)
2.0
TEPC Diameter
Live Time
(cm)
(sec)
12.7
59151

$\underline{\text { TEPC \# }}$

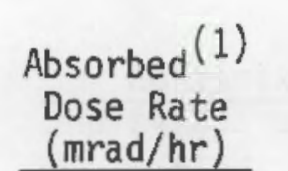

$1.32 \pm 0.10$

Proton Drop

Point

Channel \#

205
Kellerer Approximation

\begin{tabular}{c}
$\begin{array}{c}\text { Average } \\
\text { Quality }\end{array}$ \\
$\begin{array}{c}\text { Dose Equivalent } \\
\text { Rate } \\
\text { Factor }\end{array}$ \\
\hline
\end{tabular}

8.7

12
Borak Approximation

\begin{tabular}{cc}
$\begin{array}{l}\text { Average } \\
\text { Quality }\end{array}$ & Dose Equivalent \\
Rate \\
Factor & (mrem/hr) \\
\hline
\end{tabular}

1D. 8

14

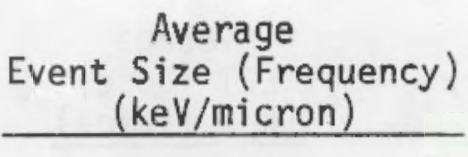

33.6
Calibration

Constant (keV/micron/channel)

0.0390
Total

Gamma Events

(Counts)

$3.408+005$
Total Neutron Dose Events (Counts $x$ Channel)

2. $394 E+007$

(1) One standard deviation from Poisson Statistics. 


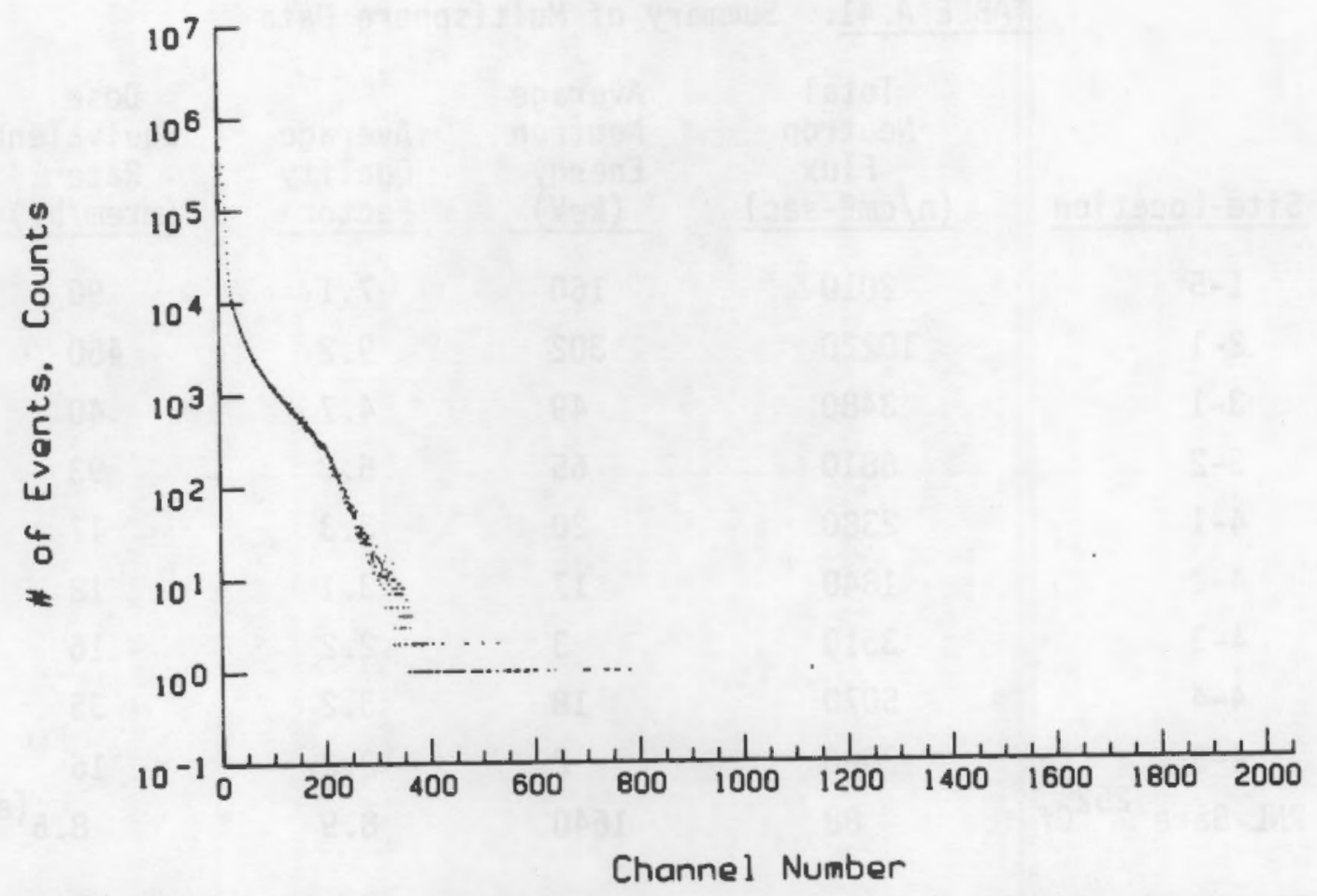

FIGURE A.45. Raw Data for Site 4 - Location 5 Neutron Measurement

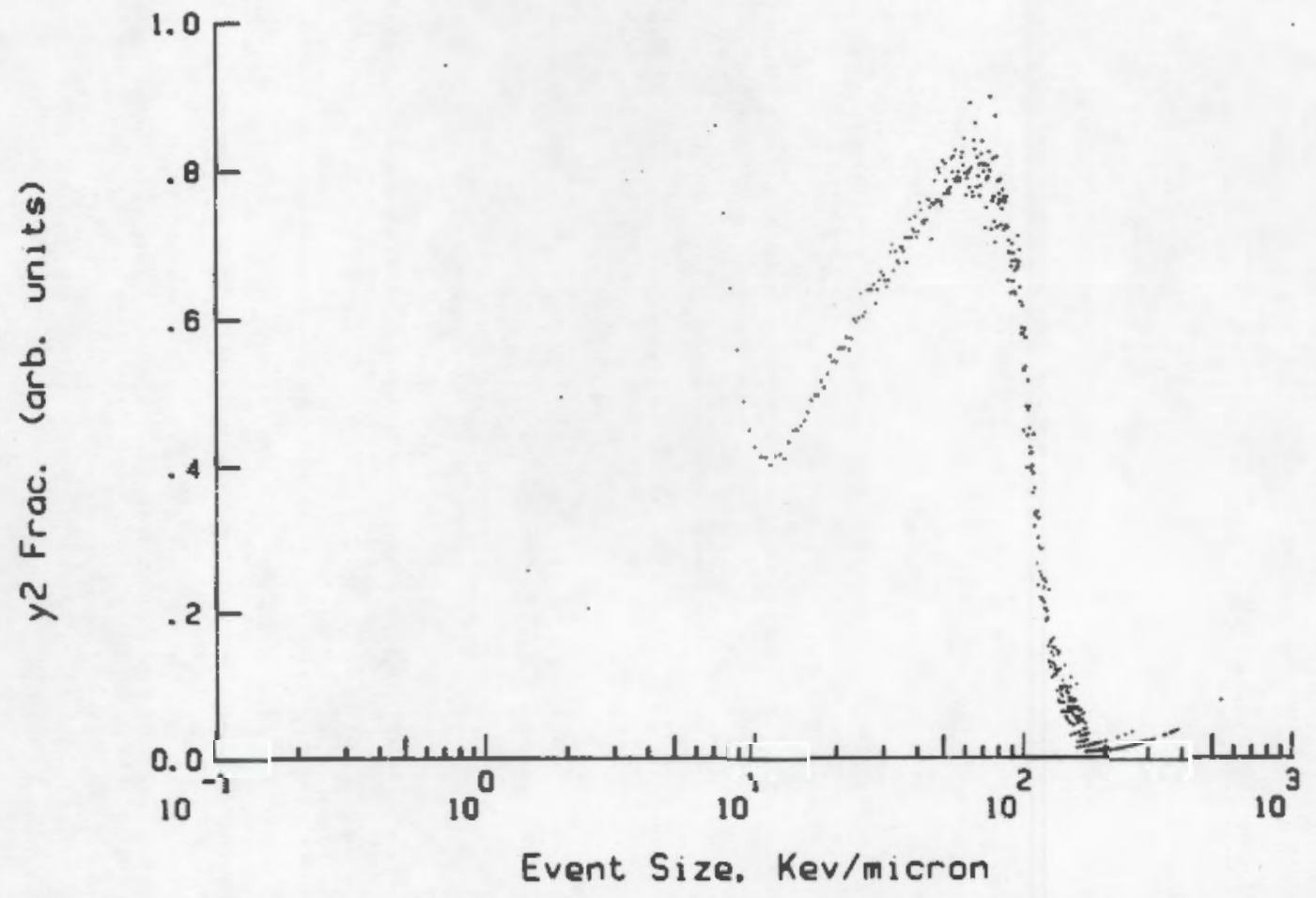

FIGURE A.46. $\gamma^{2}$ Distribution for Site 4 - Location 5 Neutron Measurement 
TABLE A.41. Summary of Multisphere Data

\begin{tabular}{|c|c|c|c|c|}
\hline Site-Location & $\begin{array}{c}\text { Total } \\
\text { Neutron } \\
\text { Flux } \\
\left(\mathrm{n} / \mathrm{cm}^{2}-\mathrm{sec}\right) \\
\end{array}$ & $\begin{array}{c}\text { Average } \\
\text { Neutron } \\
\text { Energy } \\
\text { (keV) } \\
\end{array}$ & $\begin{array}{l}\text { Average } \\
\text { Quality } \\
\text { Factor } \\
\end{array}$ & $\begin{array}{c}\text { Dose } \\
\text { Equivalent } \\
\text { Rate } \\
\text { (mrem } / \mathrm{hr} \text { ) } \\
\end{array}$ \\
\hline $1-5$ & 2010 & 160 & 7.1 & 90 \\
\hline $2-1$ & 10220 & 302 & 9.2 & 450 \\
\hline $3-1$ & 3480 & 49 & 4.7 & 40 \\
\hline $3-2$ & 6810 & 65 & 5.2 & 93 \\
\hline $4-1$ & 2380 & 20 & 3.3 & 17 \\
\hline $4-2$ & 1840 & 17 & 3.1 & 12 \\
\hline $4-3$ & 3510 & 3 & 2.2 & 16 \\
\hline $4-4$ & 5070 & 18 & 3.2 & 35 \\
\hline 4-5 & 3680 & 2 & 2.2 & 16 \\
\hline PNL Bare ${ }^{252} \mathrm{Cf}$ & 88 & 1640 & 8.9 & $8.6^{\text {(a }}$ \\
\hline
\end{tabular}

(a) At 1 meter, dose equivalent rate at $50 \mathrm{~cm}=35 \mathrm{mrem} / \mathrm{hr}$. 
TABLE A.42. Multisphere Data for Site 1 - Location 5

Detector Responses (Measured and Calculated) Number of Iterations $=96 \quad$ Error $=3.0 \%$ Detector Responses (Measured and Calculated)

$\begin{array}{llllllll} & \text { Bare } & \text { Cd-Cover } & 3-\text { inch } & 5 \text {-inch } & 8 \text {-inch } & \text { 1D-inch } & 12-\text { inch } \\ \text { Meas } & 462.60 & 378.20 & 2449.20 & 2980.70 & 1497.50 & 686.10 & 311.60 \\ \text { Calc } & 521.80 & 325.38 & 2647.83 & 2960.22 & 1296.48 & 698.05 & 316.15\end{array}$

\begin{tabular}{|c|c|c|c|c|}
\hline \multirow[b]{2}{*}{$\begin{array}{l}\text { Bin } \\
\text { No. }\end{array}$} & \multirow[b]{2}{*}{$\begin{array}{l}\text { Energy } \\
(\mathrm{MeV})\end{array}$} & \multirow[b]{2}{*}{$\begin{array}{c}\text { Flux } \\
\left(\mathrm{n} / \mathrm{cm}^{2}-\mathrm{s}\right) \\
\end{array}$} & \multicolumn{2}{|c|}{ Differential } \\
\hline & & & $\begin{array}{l}\text { Dose } \\
\text { (rad/hr) }\end{array}$ & $\begin{array}{l}\text { Dose Equiv } \\
\text { (rem/hr) }\end{array}$ \\
\hline 1 & $2.57 \mathrm{E}-007$ & $1.00 \mathrm{E}+002$ & 1. $90 \mathrm{E}-004$ & $4.04 \mathrm{E}-004$ \\
\hline 2 & $5.48 \mathrm{E}-007$ & $7.28 E+000$ & $1.60 E-005$ & $3.33 \mathrm{E}-005$ \\
\hline 3 & $1.06 \mathrm{E}-006$ & $7.10 E+000$ & $1.58 \mathrm{E}-005$ & $3.31 E-005$ \\
\hline 4 & $2.25 E-006$ & $1.82 E+001$ & $4.02 E-005$ & $8.52 \mathrm{E}-005$ \\
\hline 5 & $4.77 \mathrm{E}-006$ & $3.30 E+001$ & $7.20 \mathrm{E}-005$ & $1.54 E-004$ \\
\hline 6 & $1.01 E-005$ & $4.44 E+001$ & $9.59 \mathrm{E}-005$ & $2.07 E-004$ \\
\hline 7 & $2.14 E-004$ & $5.15 \mathrm{E}-00 \mathrm{I}$ & $1.11 \mathrm{E}-004$ & $2.35 E-004$ \\
\hline 8 & $4.52 \mathrm{E}-005$ & $5.97 \mathrm{E}+001$ & $1.28 \mathrm{E}-004$ & $2.66 \mathrm{E}-004$ \\
\hline 9 & $9.58 \mathrm{E}-005$ & $5.82 \mathrm{E}-00 \mathrm{I}$ & $1.23 \mathrm{E}-004$ & $2.52 E-004$ \\
\hline 10 & $2.03 \mathrm{E}-004$ & $5.24 \mathrm{E}+00 \mathrm{I}$ & $1.08 \mathrm{E}-004$ & 2. $18 \mathrm{E}-004$ \\
\hline 11 & $4.34 E-004$ & $5.67 \mathrm{E}+001$ & $1.11 E-004$ & $2.26 \mathrm{E}-004$ \\
\hline 12 & $9.13 \mathrm{E}-004$ & $5.93 E+00 I$ & 1. $12 E-004$ & $2.26 \mathrm{E}-004$ \\
\hline 13 & 1.92E-003 & $7.24 E+001$ & $1.34 \mathrm{E}-004$ & 2. $70 \mathrm{E}-004$ \\
\hline 14 & $4.07 \mathrm{E}-003$ & $8.56 \mathrm{E}+001$ & $1.57 \mathrm{E}-004$ & $3.15 \mathrm{E}-004$ \\
\hline 15 & $8.62 \mathrm{E}-003$ & $9.74 E+001$ & $3.57 \mathrm{E}-004$ & $3.57 \mathrm{E}-004$ \\
\hline 16 & $1.83 \mathrm{E}-002$ & $1.28 \mathrm{E}+002$ & $2.59 \mathrm{E}-004$ & 7. $15 \mathrm{E}-004$ \\
\hline 17 & $3.86 \mathrm{E}-00 \hat{2}$ & $1.72 \mathrm{E}+002$ & $4.11 \mathrm{E}-004$ & $1.75 E-003$ \\
\hline 18 & $8.18 E-002$ & $2.25 E+002$ & $6.36 \mathrm{E}-004$ & $4.27 \mathrm{E}-003$ \\
\hline 19 & $1.67 E-001$ & $2.54 \mathrm{E}+002$ & $9.50 E-004$ & $8.08 E-003$ \\
\hline 20 & $3.37 E-001$ & $2.37 E+002$ & $1.24 \mathrm{E}-003$ & 1. $24 \mathrm{E}-002$ \\
\hline 21 & $6.79 E-001$ & $1.47 E+002$ & $1.19 E-003$ & $1.29 \mathrm{E}-002$ \\
\hline 22 & $1.39 E+000$ & $4 E+001$ & $4.46 \mathrm{E}-004$ & 4. $40 \mathrm{E}-003$ \\
\hline 23 & $2.78 E+000$ & $9 E+000$ & $1.00 \mathrm{E}-004$ & $8.16 \mathrm{E}-004$ \\
\hline 24 & +000 & -001 & $1.91 \mathrm{E}-005$ & $1.34 E-005$ \\
\hline 25 & 1. $12 \mathrm{E}+001$ & $1.21 E-001$ & $2.88 \mathrm{E}-006$ & $1.99 E-005$ \\
\hline 26 & $2.04 \mathrm{E}+001$ & -002 & I. $95 \mathrm{E}$ & $1.35 E-005$ \\
\hline Total & & +003 & .003 & $4.88 \mathrm{E}-002$ \\
\hline
\end{tabular}

Total Flux $\quad=2.01 \mathrm{E}+003 \mathrm{n} / \mathrm{cm}^{2}-\mathrm{sec}$

Dose Rate $\quad=6.84 \mathrm{E}-003 \mathrm{rad} / \mathrm{hr}$

Dose Equivalent Rate $=4.88 \mathrm{E}-002 \mathrm{rem} / \mathrm{hr}$

Ave. Quality Factor $=7.12$

Average Energy $\quad=0.16 \mathrm{MeV}$ 


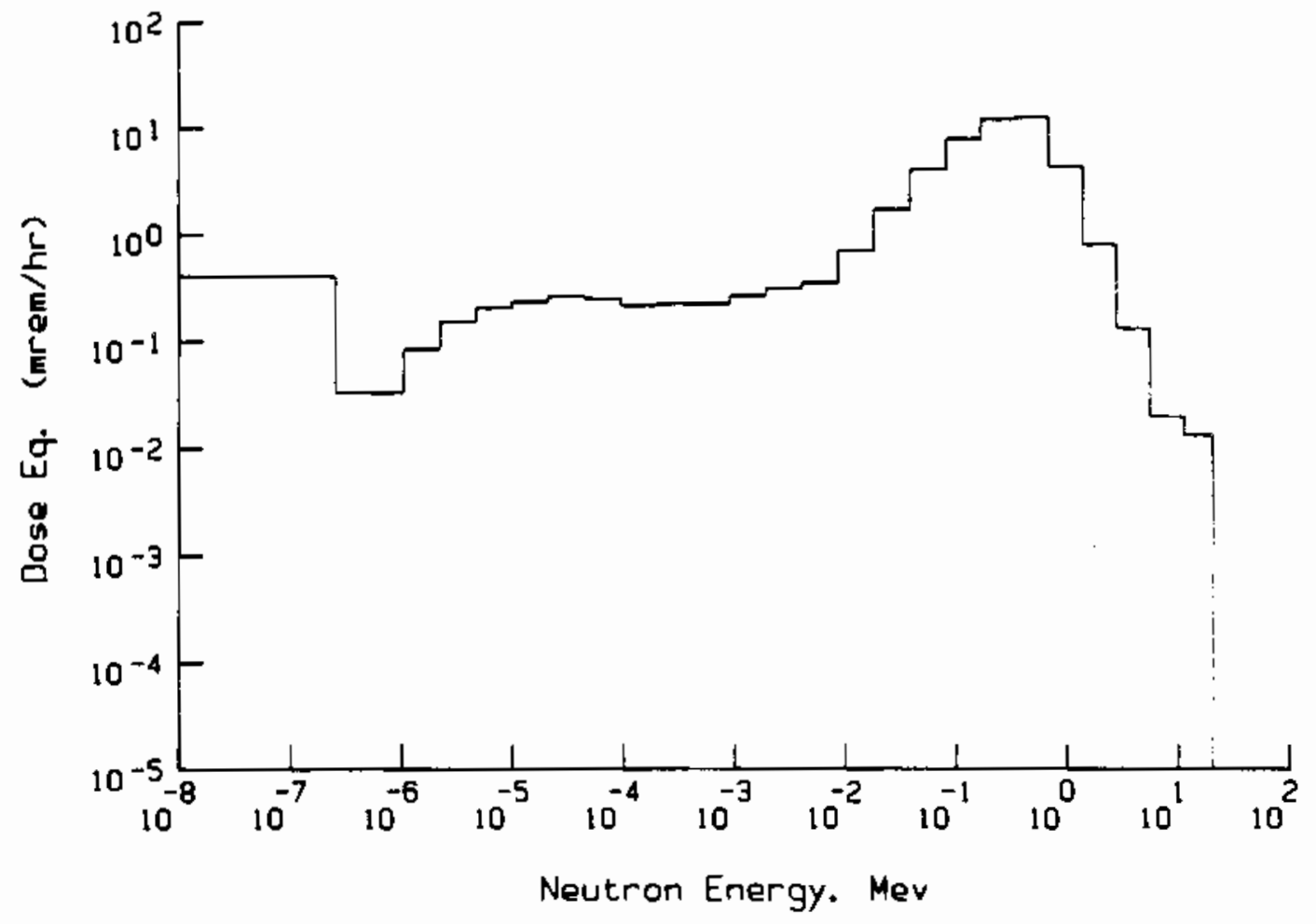

FIGURE A.47. Site 1 - Location 5 Dose Equivalent Spectrum

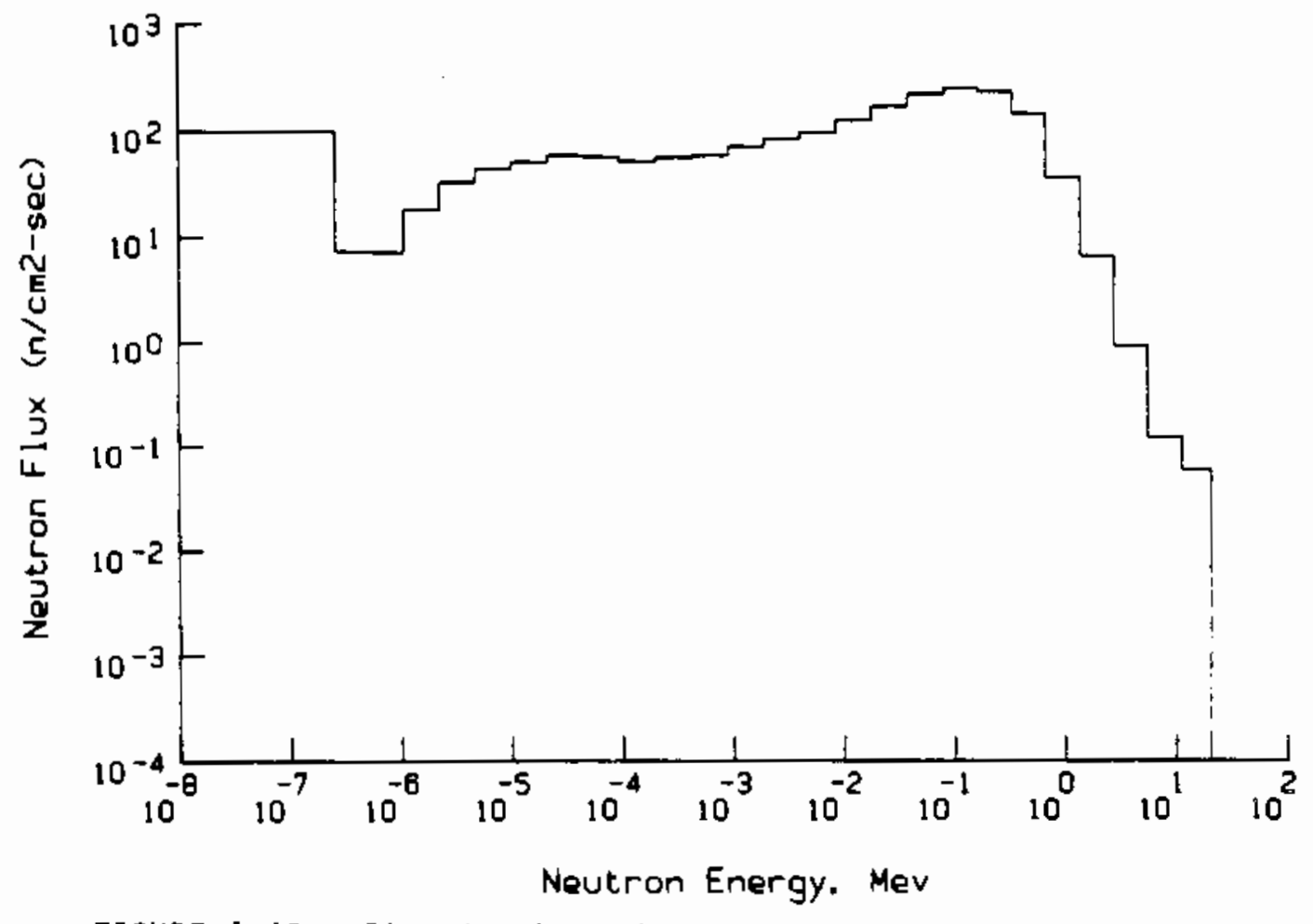

FIGURE A.48. Site 1 - Location 5 Neutron FTux Spectrum 
TABLE A.43. Multisphere Data for Site 2 - Locations 1 and 2

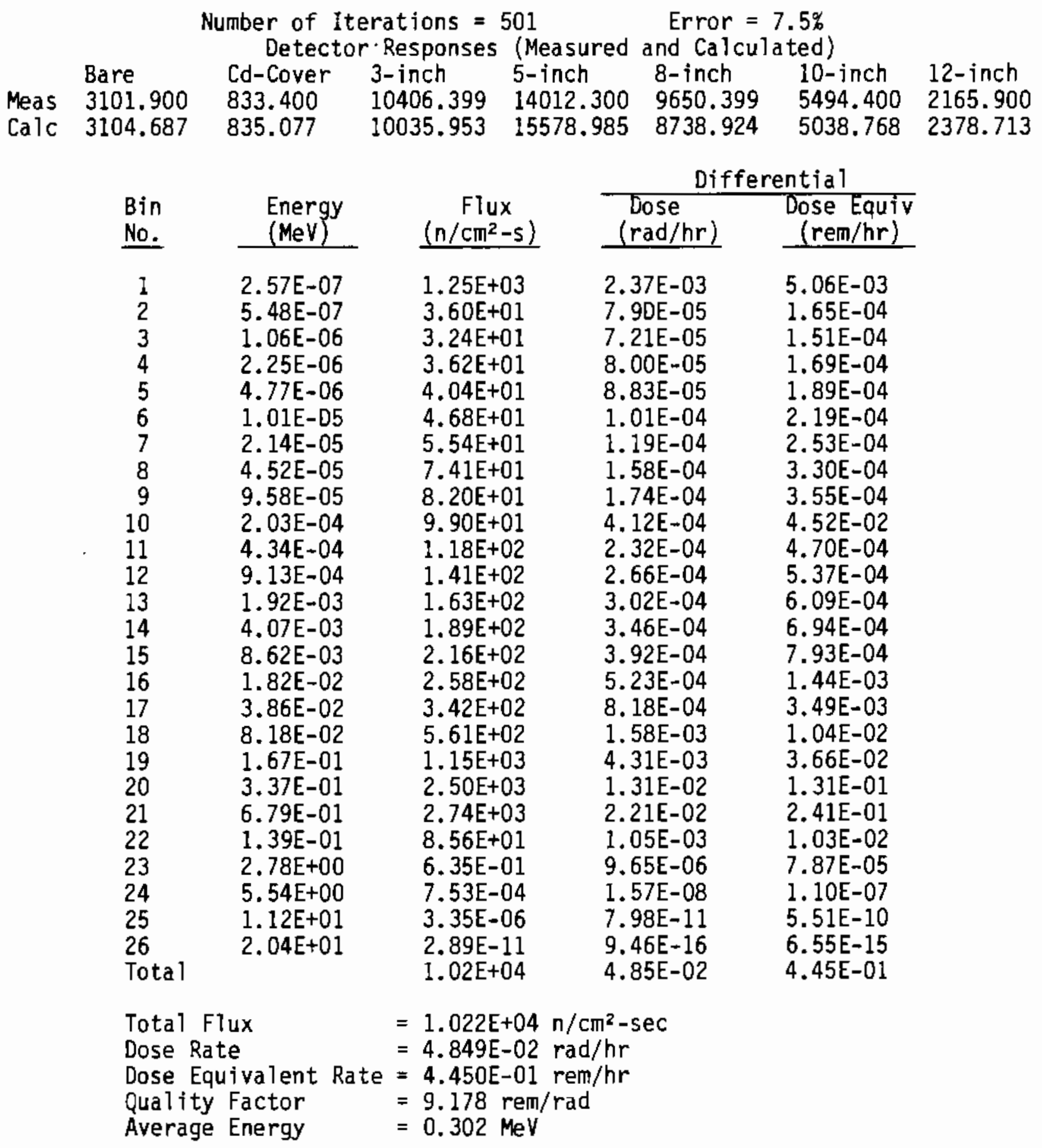




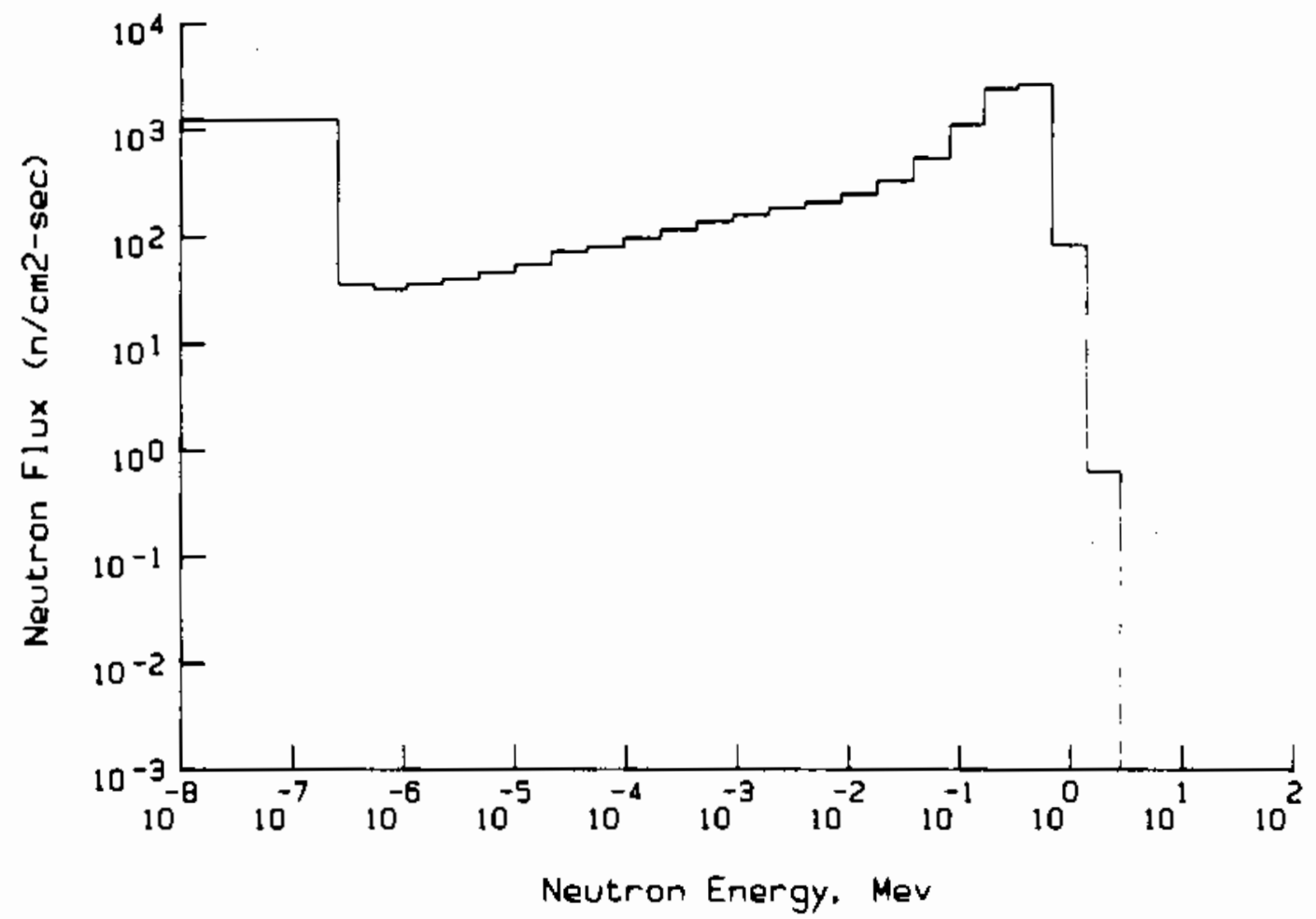

FIGURE A.49. Site 2 Neutron Flux Spectrum

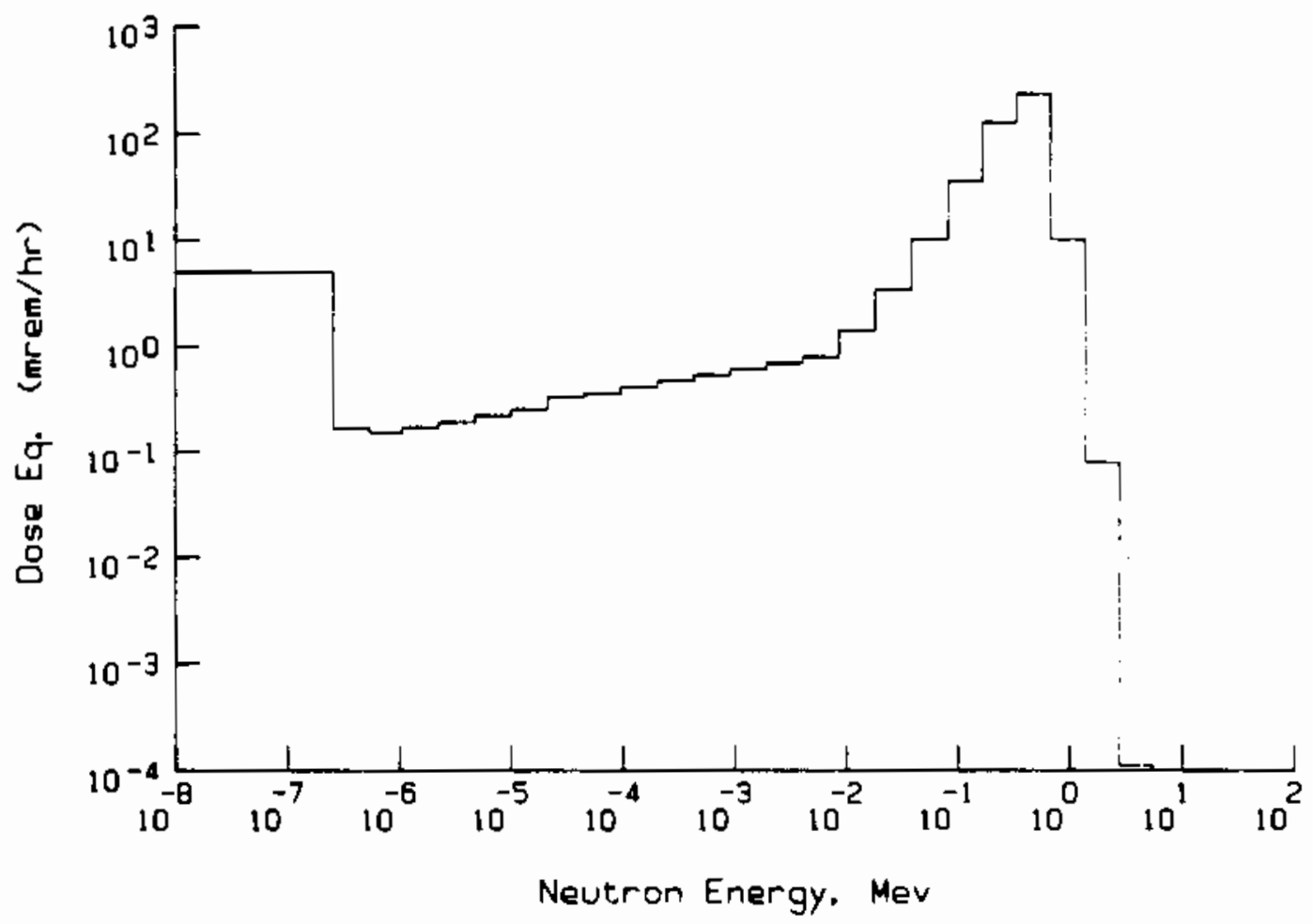

FIGURE A.50. Site 2 Dose Equivalent Spectrum 
TABLE A.44. Multisphere Data for Site 3 - Location 1

Number of Iterations $=501 \quad$ Error $=4.0 \%$ Detector Responses (Measured and Caicuiated)

$\begin{array}{llllllll} & \text { Bare } & \text { Cd-Cover } & 3-\text { inch } & 5 \text {-inch } & 8 \text {-inch } & 10-\text { inch } & 12 \text {-inch } \\ \text { Meas } & 3290.410 & 1178.440 & 3338.920 & 3077.890 & 1366.730 & 585.740 & 255.020 \\ \text { Calc } & 3298.698 & 1175.656 & 3353.207 & 3123.955 & 1253.216 & 621.753 & 255.573\end{array}$

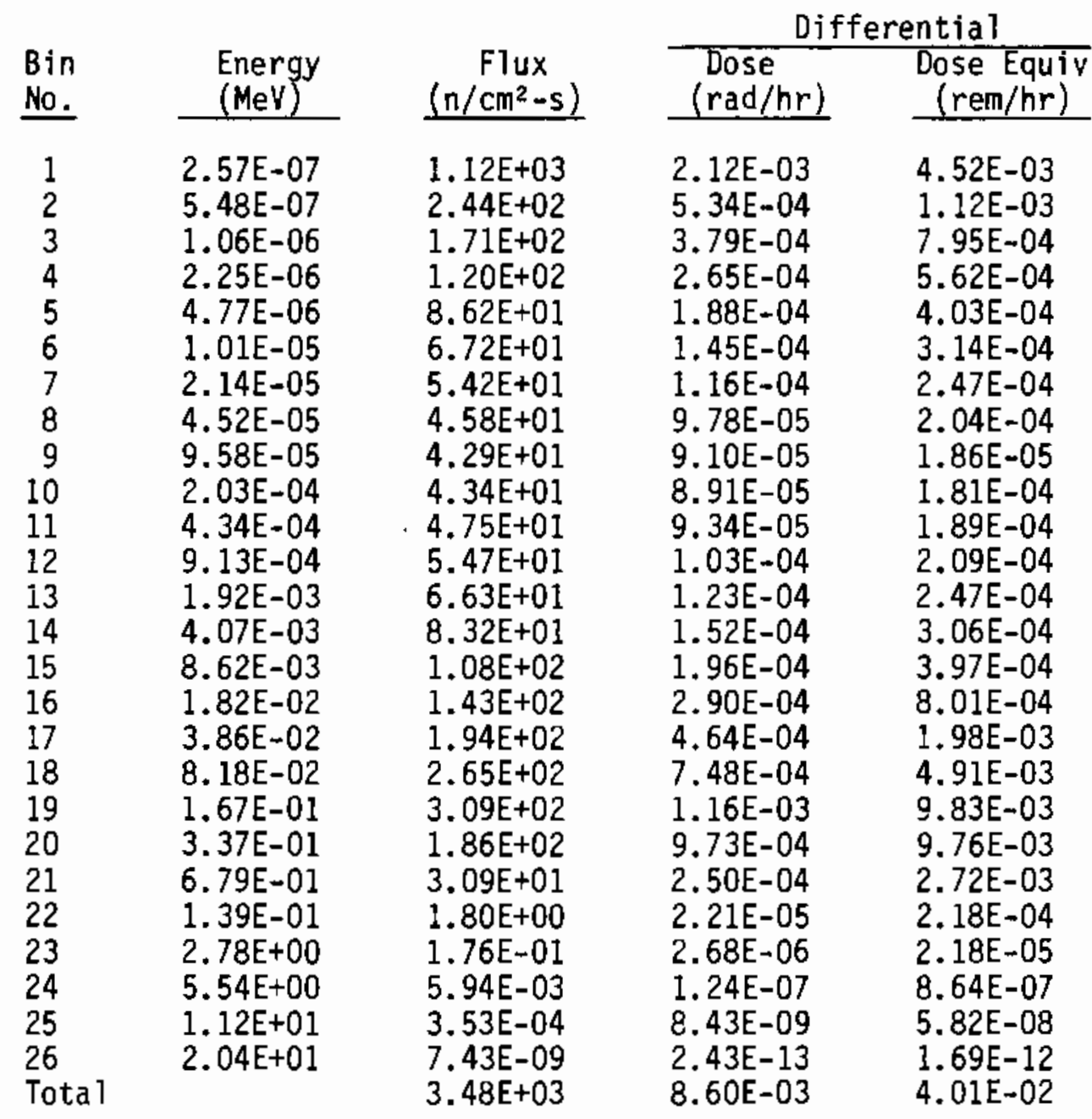




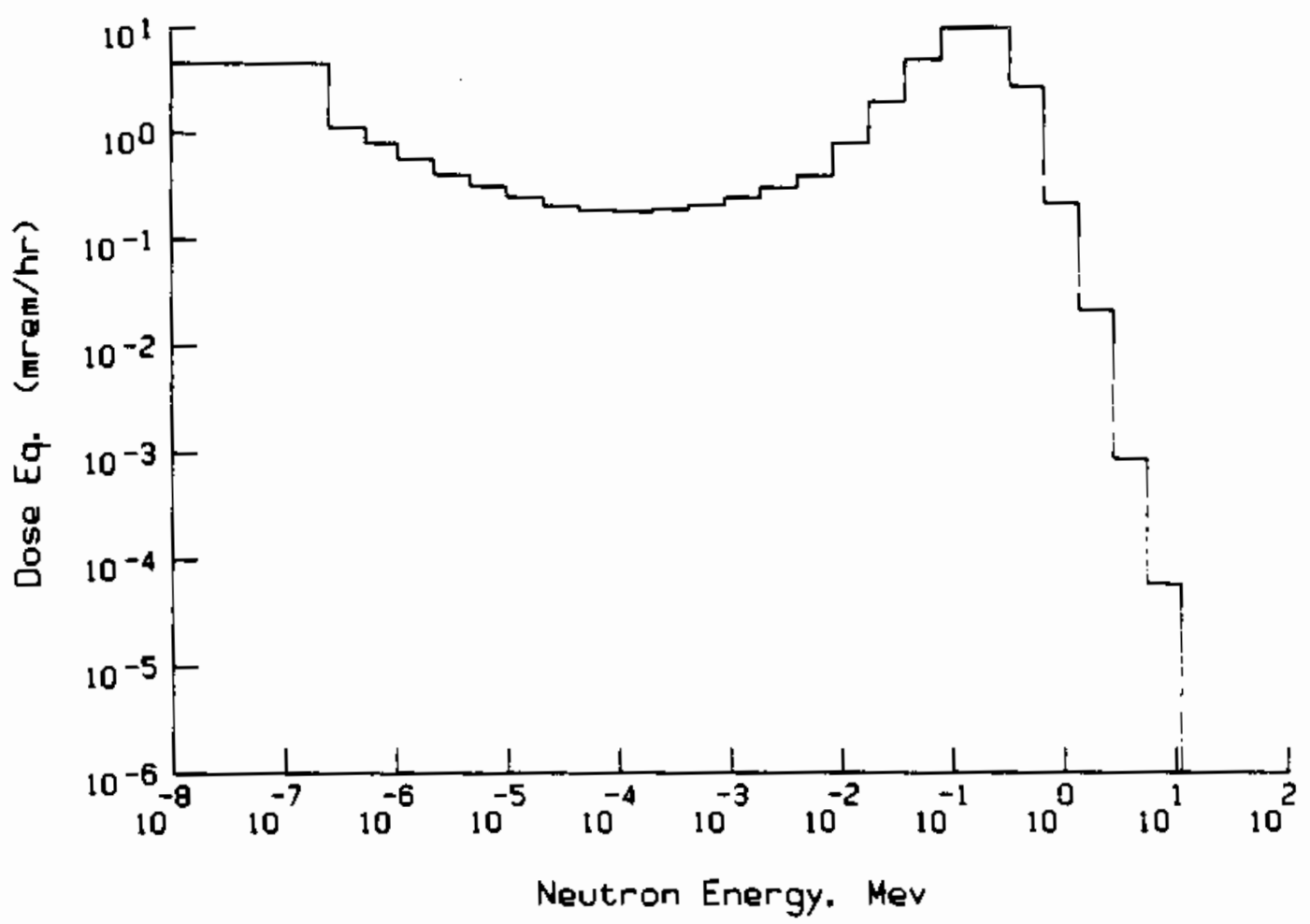

FIGURE A.51. Site 3 - Location 1 Dose Equivalent Spectrum

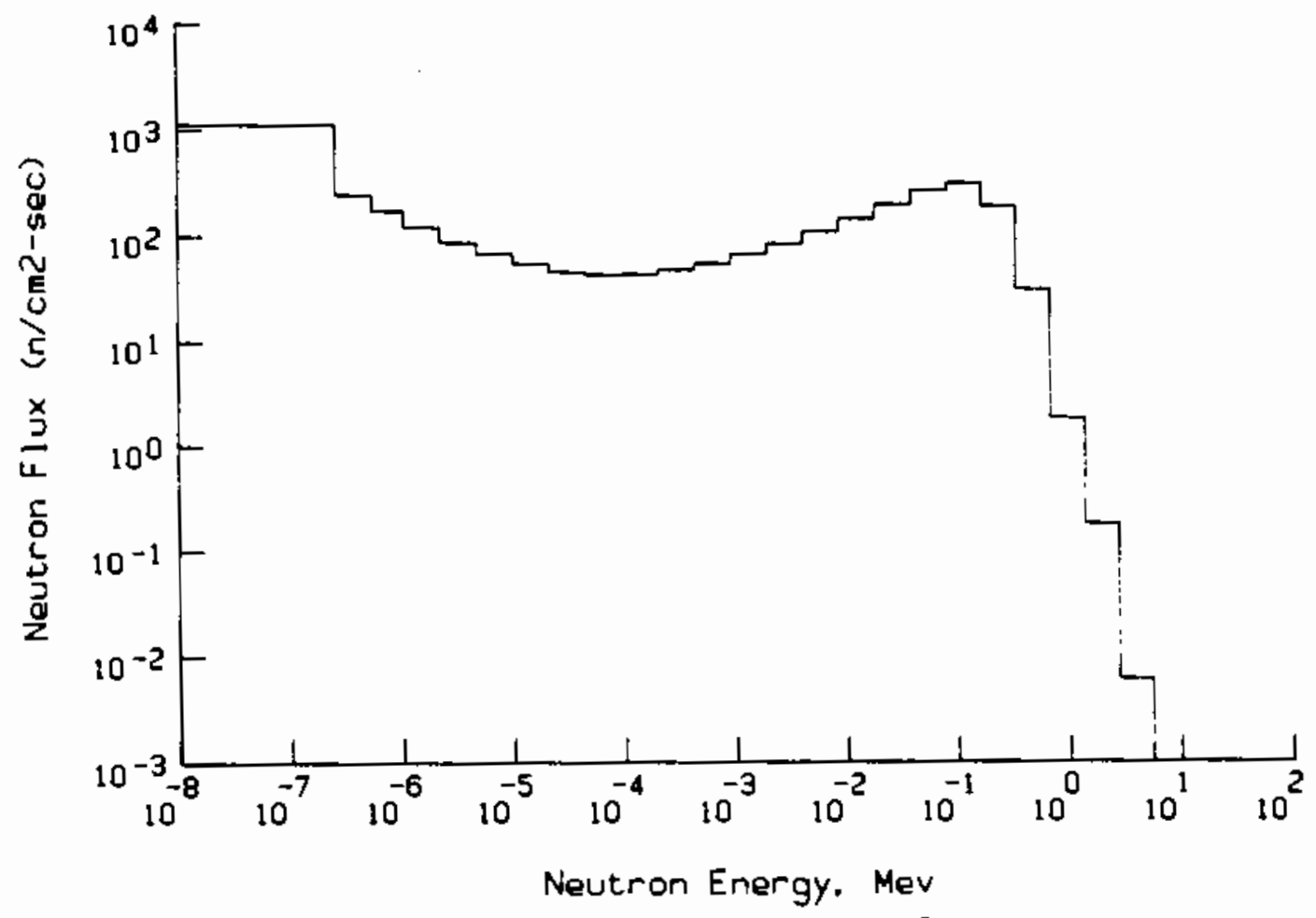

FIGURE A.52. Site 3 - Location 1 Neutron Flux Spectrum 
TABLE A.45. Multisphere Data for Site 3 Location 2

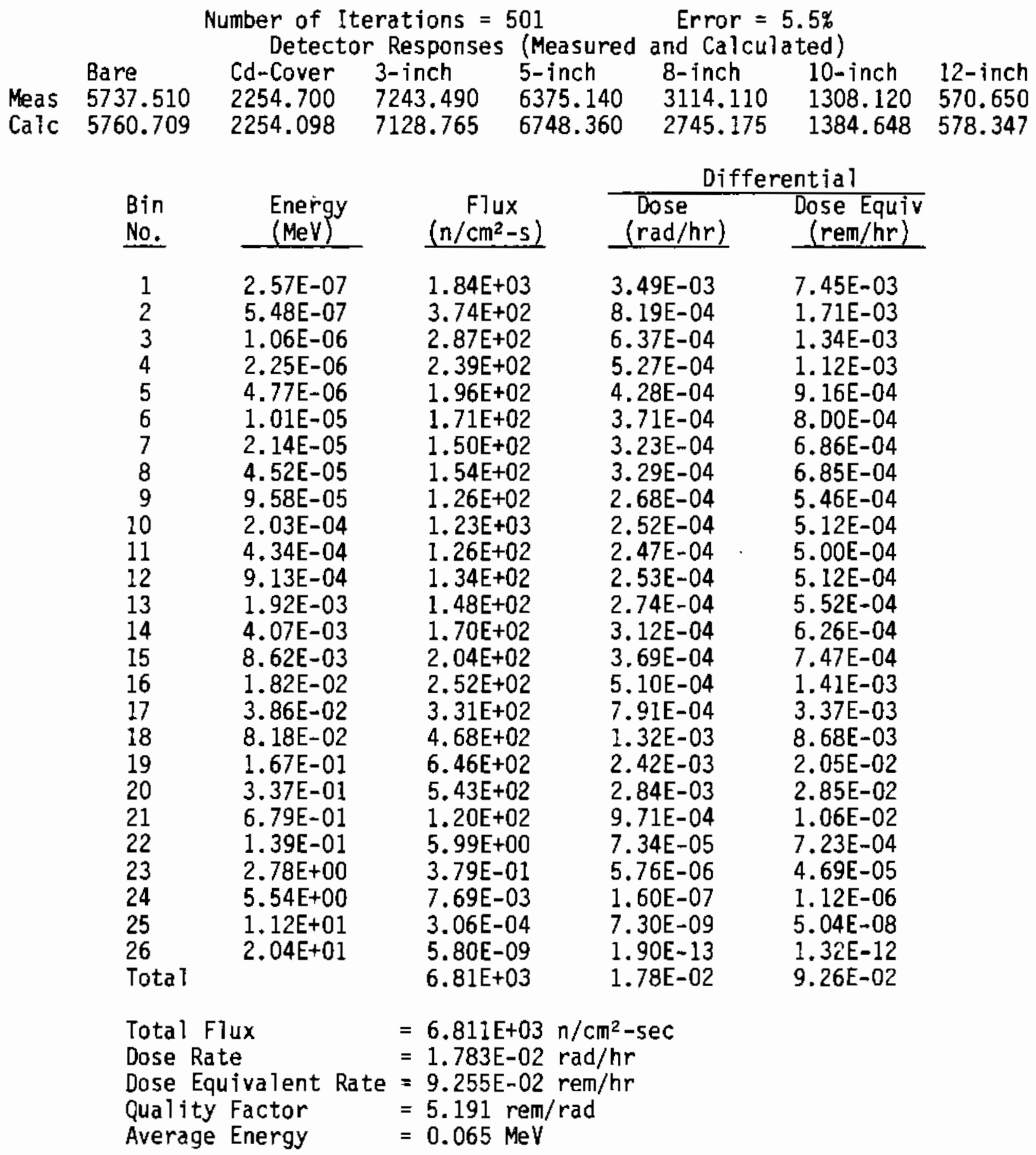




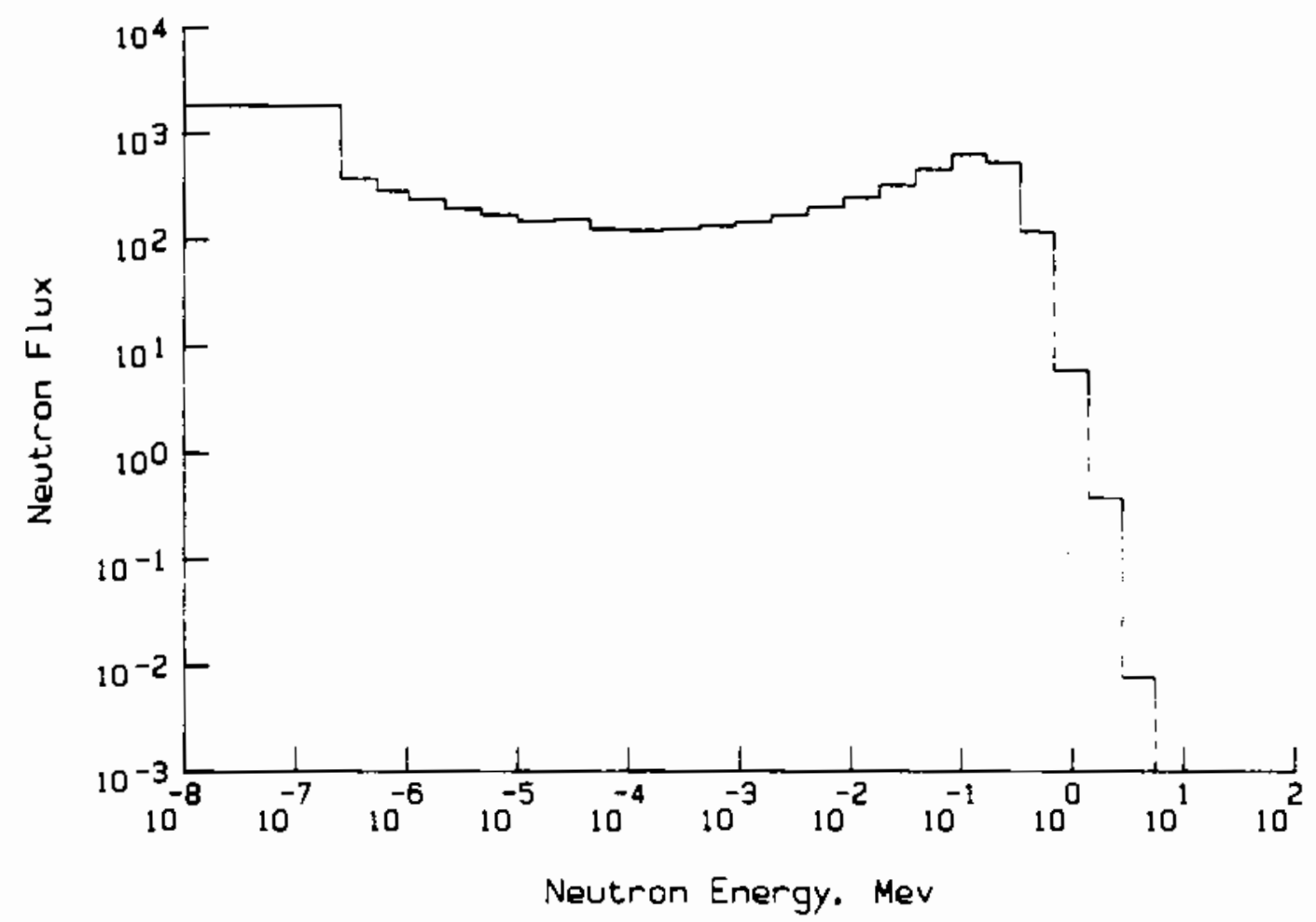

FIGURE A.53. Site 3 - Location 2 Neutron FIux Spectrum

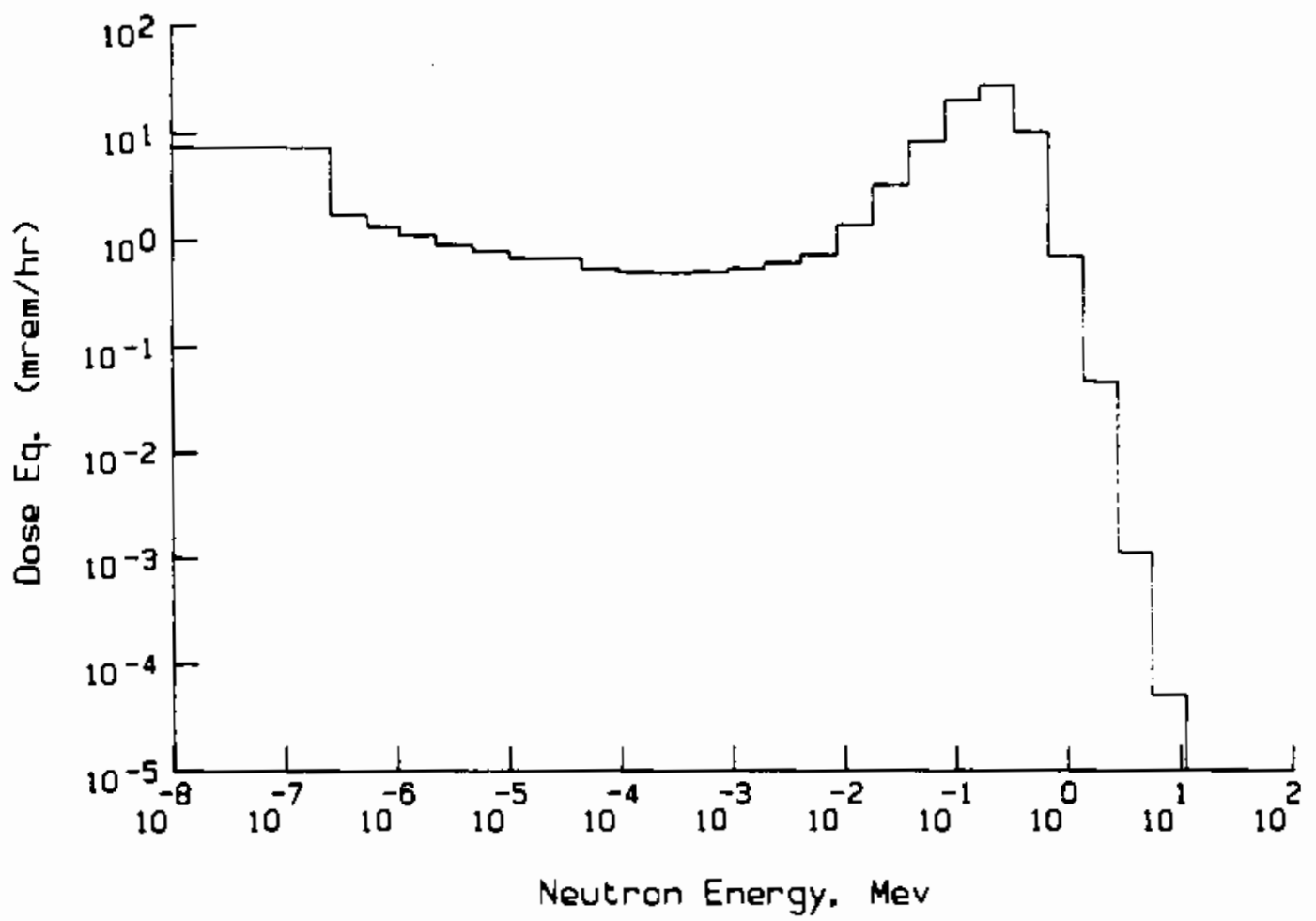

FIGURE A.54. Site 3 - Location 2 Dose Equivalent Spectrum 
TABLE A.46. Site 4 Location 1

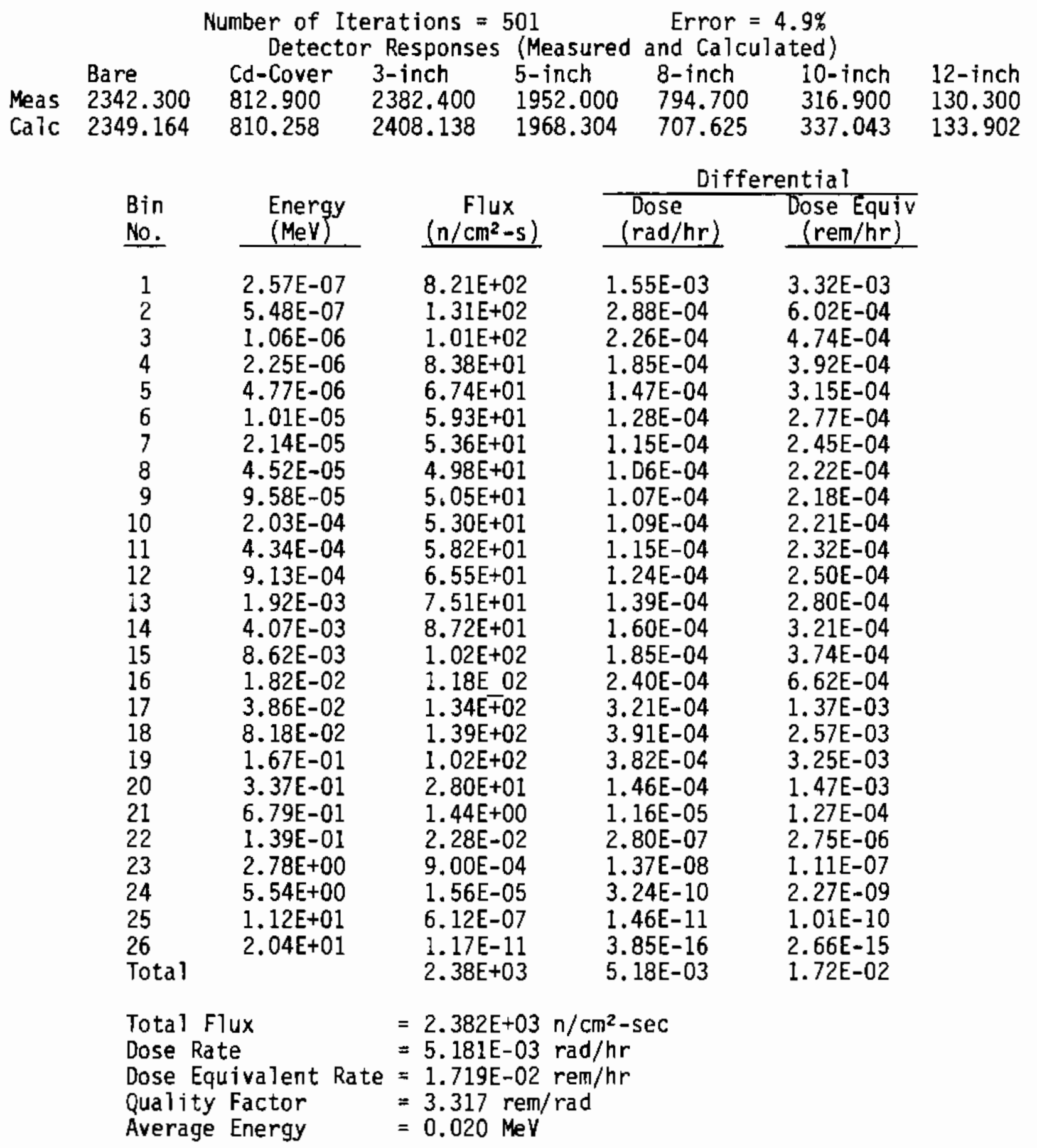




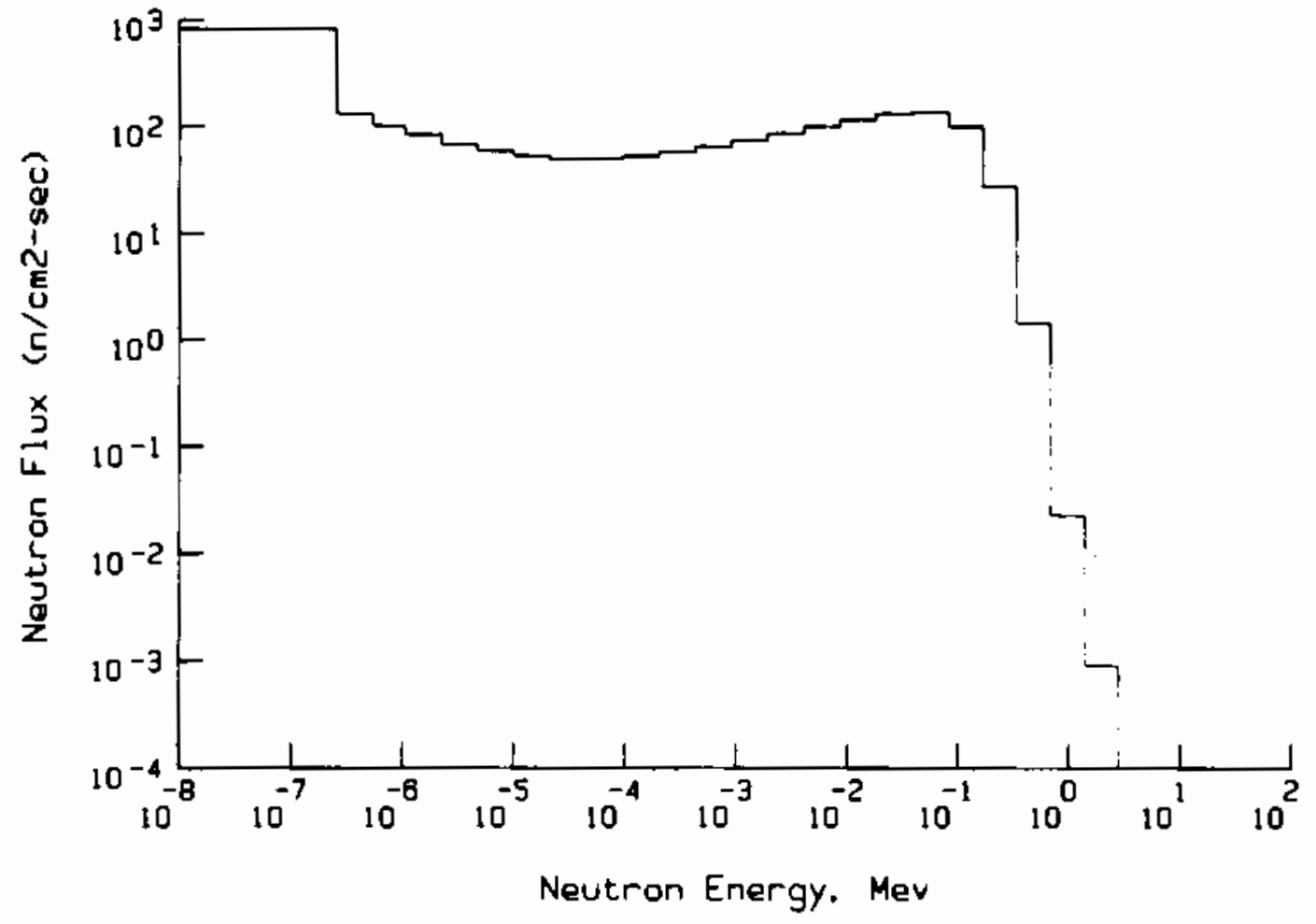

FIGURE A.55. Site 4 - Location 1 Neutron Flux Spectrum

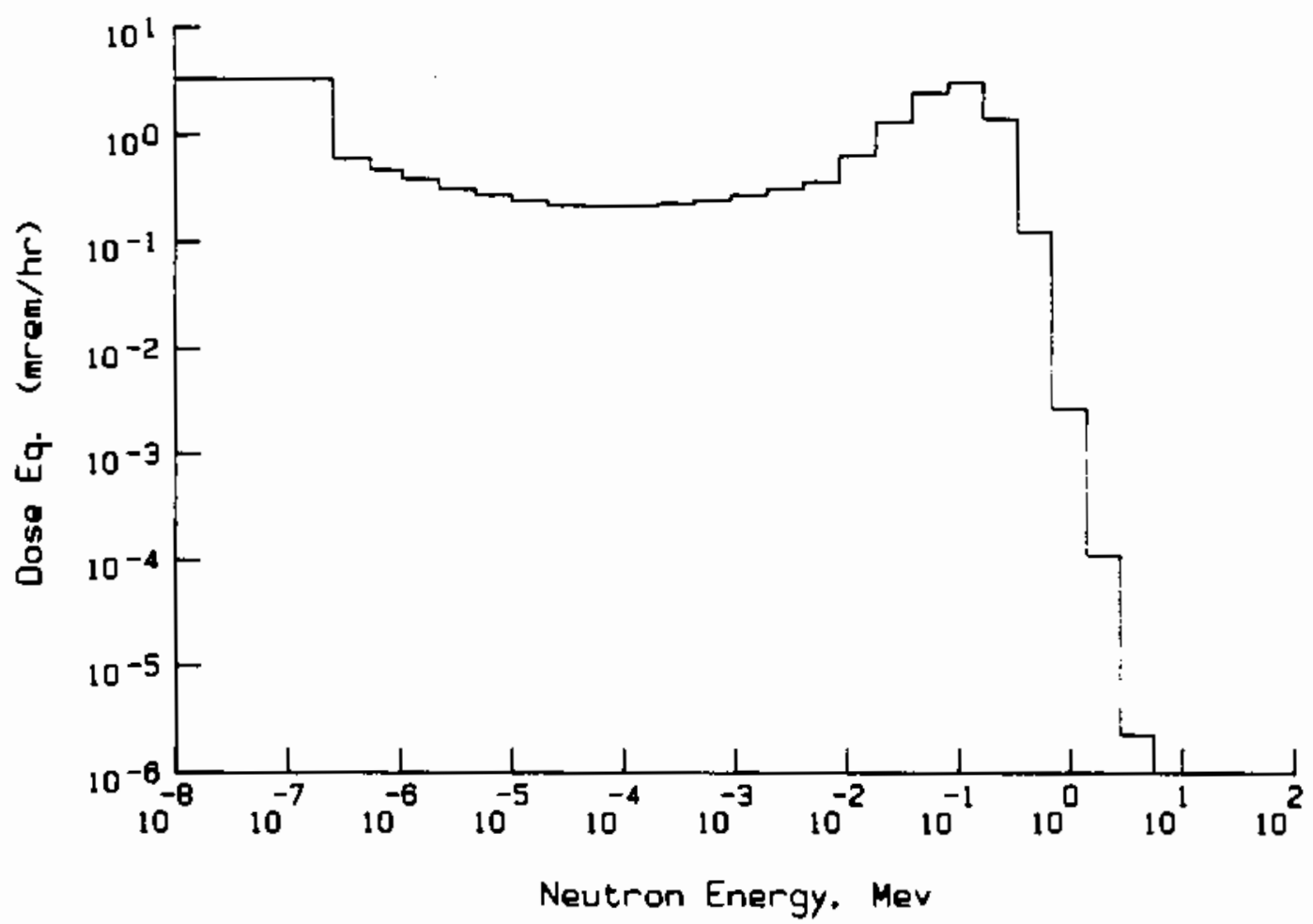

FIGURE A.56. Site 4 - Location 1 Dose Equivalent Spectrum 
TABLE A.47. Site 4 Location 2

Number of Iterations $=501 \quad$ Error $=5.9 \%$

Detector Responses (Measured and Calculated)

$\begin{array}{llllllll} & \text { Bare } & \text { Cd-Cover } & 3 \text {-inch } & 5 \text {-inch } & 8 \text {-inch } & 10 \text {-inch } & 12 \text {-inch } \\ \text { Meas } & 1856.700 & 532.600 & 2693.500 & 1447.700 & 600.300 & 233.800 & 92.300 \\ \text { Calc } & 1861.488 & 530.514 & 1725.885 & 1440.054 & 522.069 & 247.359 & 97.822\end{array}$

\begin{tabular}{|c|c|c|c|c|}
\hline \multirow[b]{2}{*}{$\begin{array}{l}\text { Bin } \\
\text { No. }\end{array}$} & \multirow[b]{2}{*}{$\begin{array}{l}\text { Energy } \\
(\mathrm{MeV})\end{array}$} & \multirow[b]{2}{*}{$\begin{array}{c}\text { Fiux } \\
\left(\mathrm{n} / \mathrm{cm} \mathbf{m}^{2}-\mathrm{s}\right) \\
\end{array}$} & \multicolumn{2}{|c|}{ Differential } \\
\hline & & & $\begin{array}{l}\text { Dose } \\
(\mathrm{rad} / \mathrm{hr})\end{array}$ & $\begin{array}{l}\text { Dose Equiv } \\
\text { (rem/hr) }\end{array}$ \\
\hline $\begin{array}{l}1 \\
2 \\
3 \\
4 \\
5 \\
6 \\
7 \\
8 \\
9 \\
10 \\
11 \\
12 \\
13 \\
14 \\
15 \\
16 \\
17 \\
18 \\
19 \\
20 \\
21 \\
22 \\
23 \\
24 \\
25 \\
26 \\
\text { Total }\end{array}$ & $\begin{array}{l}2.57 \mathrm{E}-07 \\
5.48 \mathrm{E}-07 \\
1.06 \mathrm{E}-06 \\
2.25 \mathrm{E}-06 \\
4.77 \mathrm{E}-06 \\
1.01 \mathrm{E}-05 \\
2.14 \mathrm{E}-05 \\
4.52 \mathrm{E}-05 \\
9.58 \mathrm{E}-05 \\
2.03 \mathrm{E}-04 \\
4.34 \mathrm{E}-04 \\
9.13 \mathrm{E}-04 \\
1.92 \mathrm{E}-03 \\
4.07 \mathrm{E}-03 \\
8.62 \mathrm{E}-03 \\
1.82 \mathrm{E}-02 \\
3.86 \mathrm{E}-02 \\
8.18 \mathrm{E}-02 \\
1.67 \mathrm{E}-01 \\
3.37 \mathrm{E}-01 \\
6.79 \mathrm{E}-01 \\
1.39 \mathrm{E}-01 \\
2.78 \mathrm{E}+00 \\
5.54 \mathrm{E}+00 \\
1.12 \mathrm{E}+01 \\
2.04 \mathrm{E}+01\end{array}$ & $\begin{array}{l}7.22 \mathrm{E}+02 \\
8.23 \mathrm{E}+01 \\
6.21 \mathrm{E}+01 \\
5.20 \mathrm{E}+01 \\
4.09 \mathrm{E}+01 \\
3.62 \mathrm{E}+01 \\
3.32 \mathrm{E}+01 \\
3.03 \mathrm{E}+01 \\
3.31 \mathrm{E}+01 \\
3.63 \mathrm{E}+01 \\
4.19 \mathrm{E}+01 \\
4.94 \mathrm{E}+01 \\
5.92 \mathrm{E}+01 \\
7.14 \mathrm{E}+01 \\
8.62 \mathrm{E}+01 \\
1.02 \mathrm{E}+02 \\
1.15 \mathrm{E}+02 \\
1.11 \mathrm{E}+03 \\
6.42 \mathrm{E}+01 \\
9.05 \mathrm{E}+00 \\
1.21 \mathrm{E}+00 \\
2.91 \mathrm{E}-04 \\
2.52 \mathrm{E}-06 \\
1.30 \mathrm{E}-08 \\
2.32 \mathrm{E}-10 \\
3.67 \mathrm{E}-15 \\
1.84 \mathrm{E}+03\end{array}$ & $\begin{array}{l}1.37 \mathrm{E}-03 \\
1.80 \mathrm{E}-04 \\
1.38 \mathrm{E}-04 \\
1.15 \mathrm{E}-04 \\
8.93 \mathrm{E}-05 \\
7.82 \mathrm{E}-05 \\
7.13 \mathrm{E}-05 \\
6.48 \mathrm{E}-05 \\
7.03 \mathrm{E}-05 \\
7.45 \mathrm{E}-05 \\
8.24 \mathrm{E}-05 \\
9.33 \mathrm{E}-05 \\
1.10 \mathrm{E}-04 \\
1.31 \mathrm{E}-04 \\
1.56 \mathrm{E}-04 \\
2.06 \mathrm{E}-04 \\
2.74 \mathrm{E}-04 \\
3.12 \mathrm{E}-04 \\
2.40 \mathrm{E}-04 \\
4.74 \mathrm{E}-05 \\
9.77 \mathrm{E}-07 \\
3.57 \mathrm{E}-09 \\
3.83 \mathrm{E}-11 \\
2.70 \mathrm{E}-13 \\
5.53 \mathrm{E}-15 \\
1.20 \mathrm{E}-19 \\
3.90 \mathrm{E}-03\end{array}$ & $\begin{array}{l}2.91 \mathrm{E}-03 \\
3.77 \mathrm{E}-04 \\
2.90 \mathrm{E}-04 \\
2.43 \mathrm{E}-04 \\
1.91 \mathrm{E}-04 \\
1.69 \mathrm{E}-04 \\
1.52 \mathrm{E}-04 \\
1.35 \mathrm{E}-04 \\
1.43 \mathrm{E}-04 \\
1.51 \mathrm{E}-04 \\
1.67 \mathrm{E}-04 \\
1.88 \mathrm{E}-04 \\
2.21 \mathrm{E}-04 \\
2.62 \mathrm{E}-04 \\
3.16 \mathrm{E}-04 \\
5.69 \mathrm{E}-04 \\
1.17 \mathrm{E}-03 \\
2.05 \mathrm{E}-03 \\
2.04 \mathrm{E}-03 \\
4.75 \mathrm{E}-04 \\
1.06 \mathrm{E}-05 \\
3.52 \mathrm{E}-08 \\
3.12 \mathrm{E}-10 \\
1.89 \mathrm{E}-12 \\
3.82 \mathrm{E}-14 \\
8.32 \mathrm{E}-19 \\
1.33 \mathrm{E}-02\end{array}$ \\
\hline \multicolumn{2}{|c|}{$\begin{array}{l}\text { Total Flux } \\
\text { Dose Rate } \\
\text { Dose Equivalent Rate } \\
\text { Quality Factor } \\
\text { Average Energy }\end{array}$} & \multicolumn{2}{|c|}{$\begin{array}{l}=1.837 \mathrm{E}+03 \mathrm{n} / \mathrm{cm}^{2}-\mathrm{sec} \\
=3.902 \mathrm{E}-03 \mathrm{rad} / \mathrm{hr} \\
=1.224 \mathrm{E}-02 \mathrm{rem} / \mathrm{hr} \\
=3.136 \mathrm{rem} / \mathrm{rad} \\
=0.017 \mathrm{MeV}\end{array}$} & \\
\hline
\end{tabular}




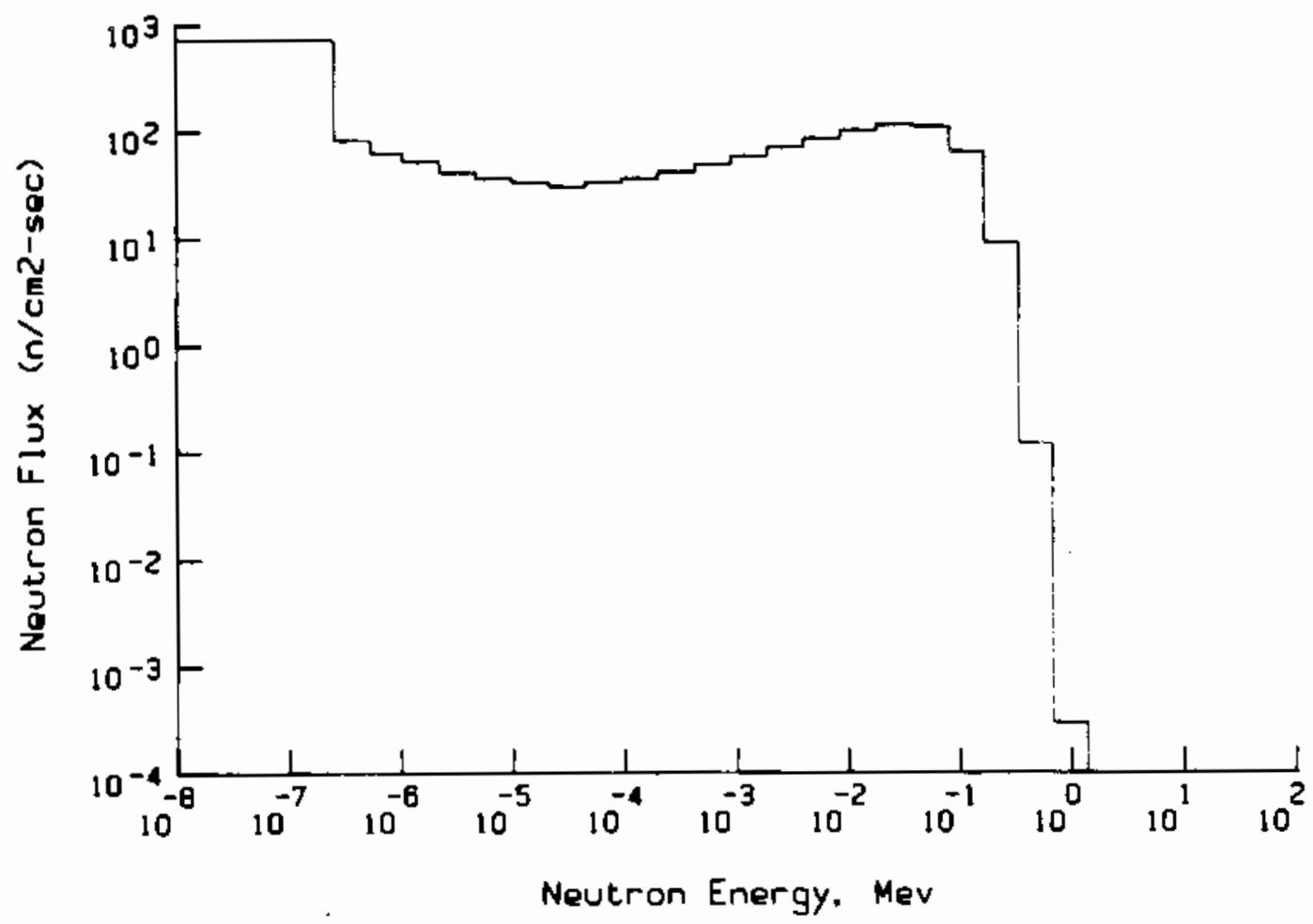

FIGURE A.57. Site 4 - Location 2 Neutron Flux Spectrum

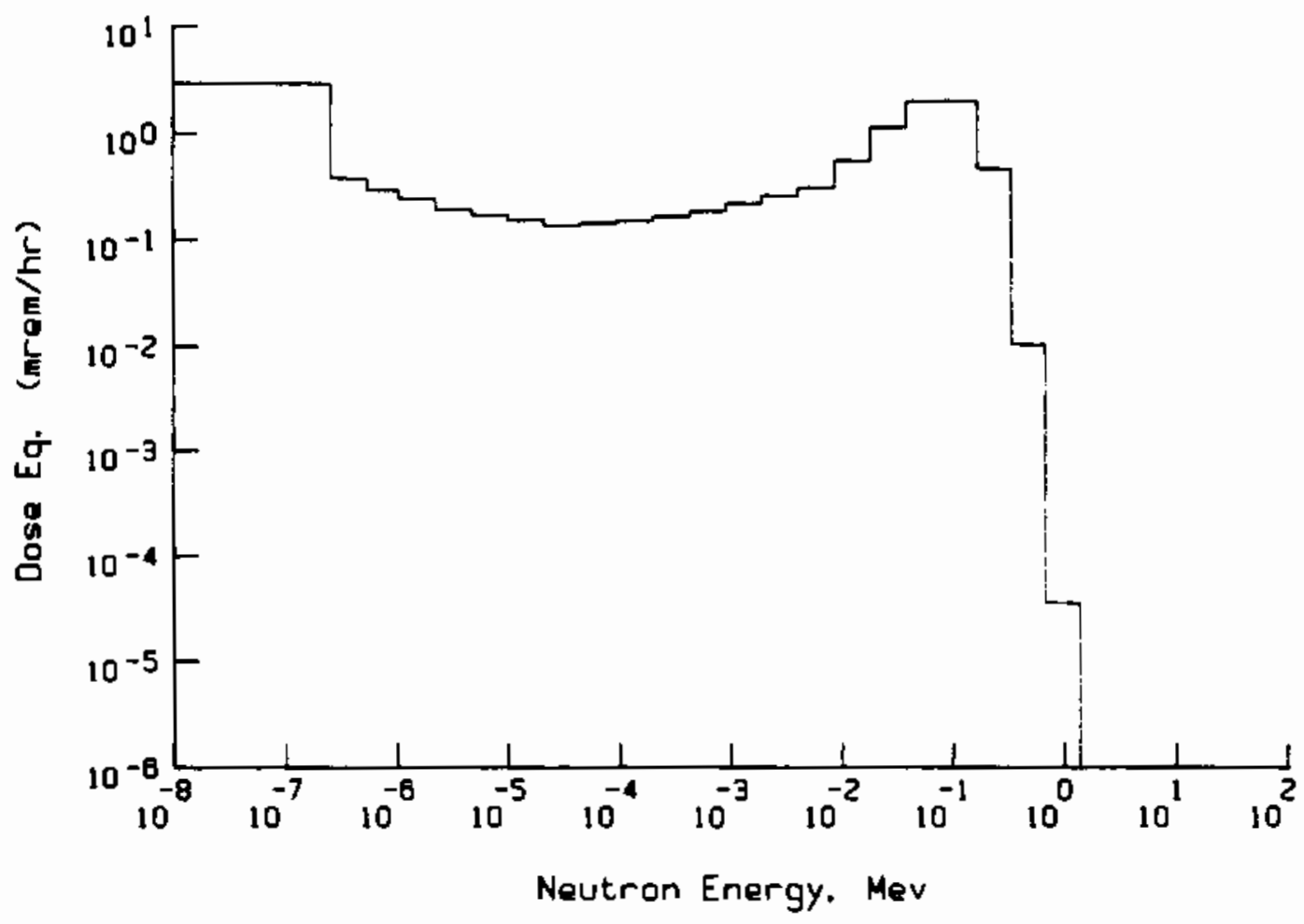

FIGURE A.58. Site 4 - Location 2 Dose Equivalent Spectrum 
IABLE A.48. Site 4 Location 3

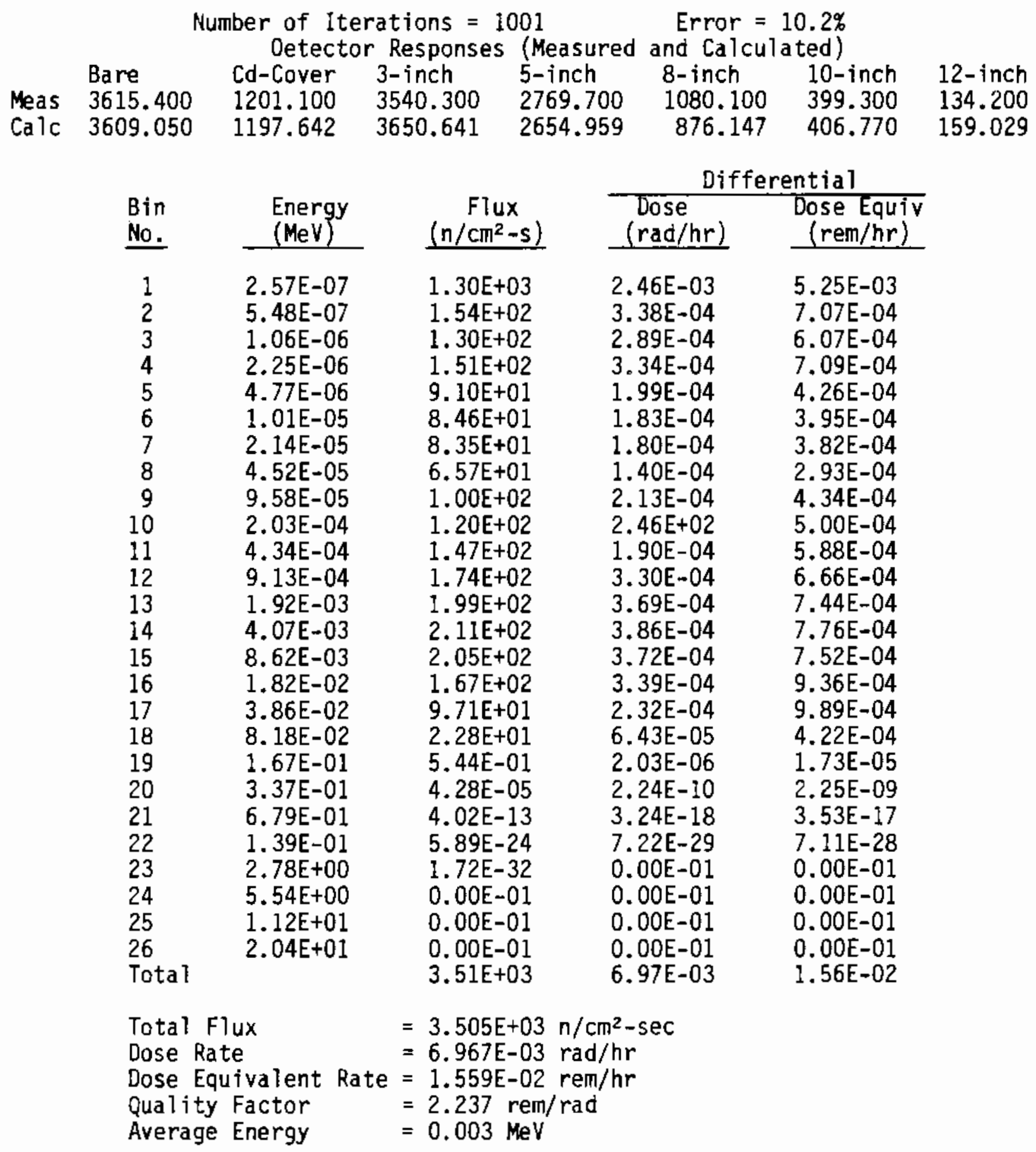




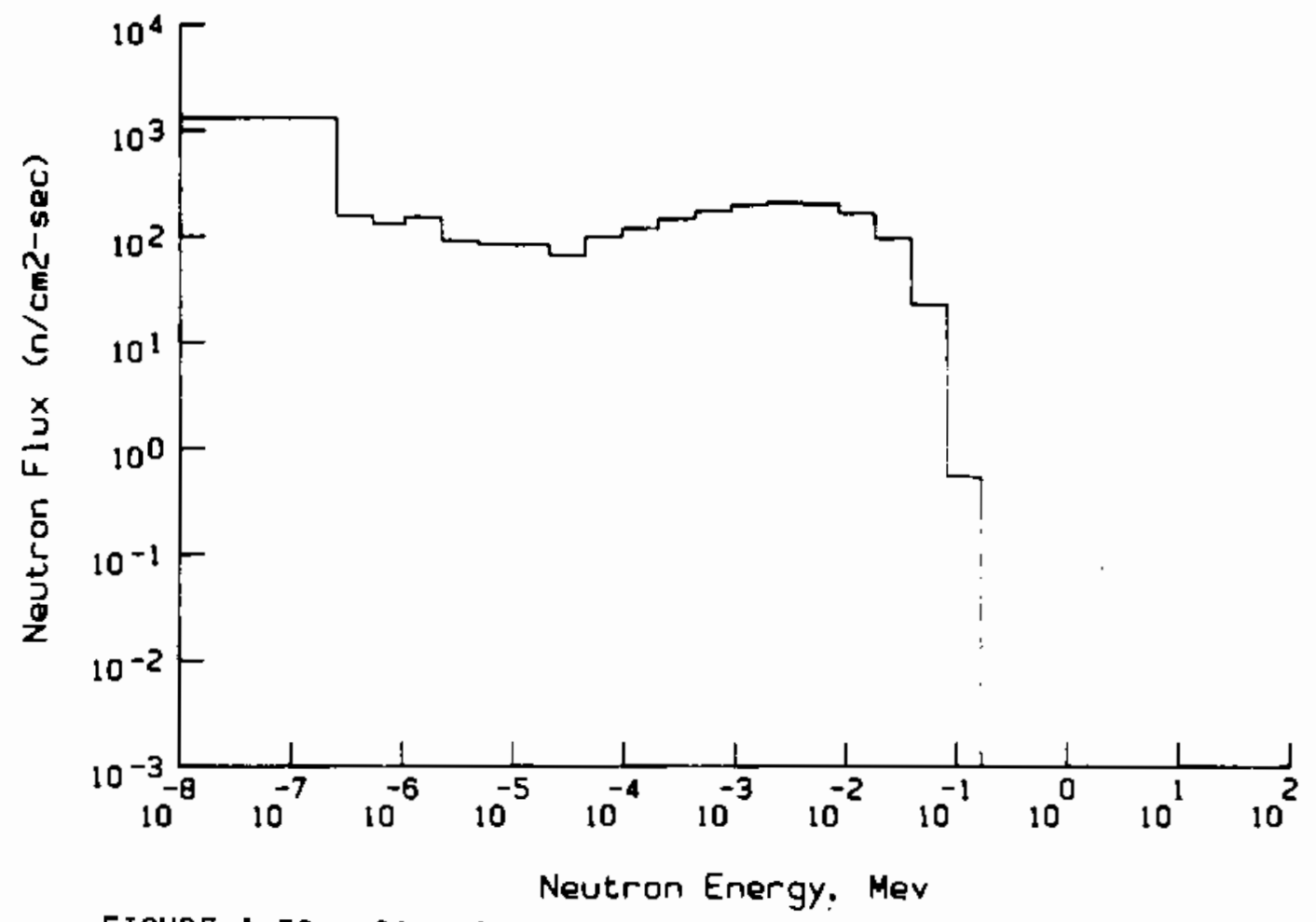

FIGURE A.59. Site 4 - Location 3 Neutron FTux Spectrum

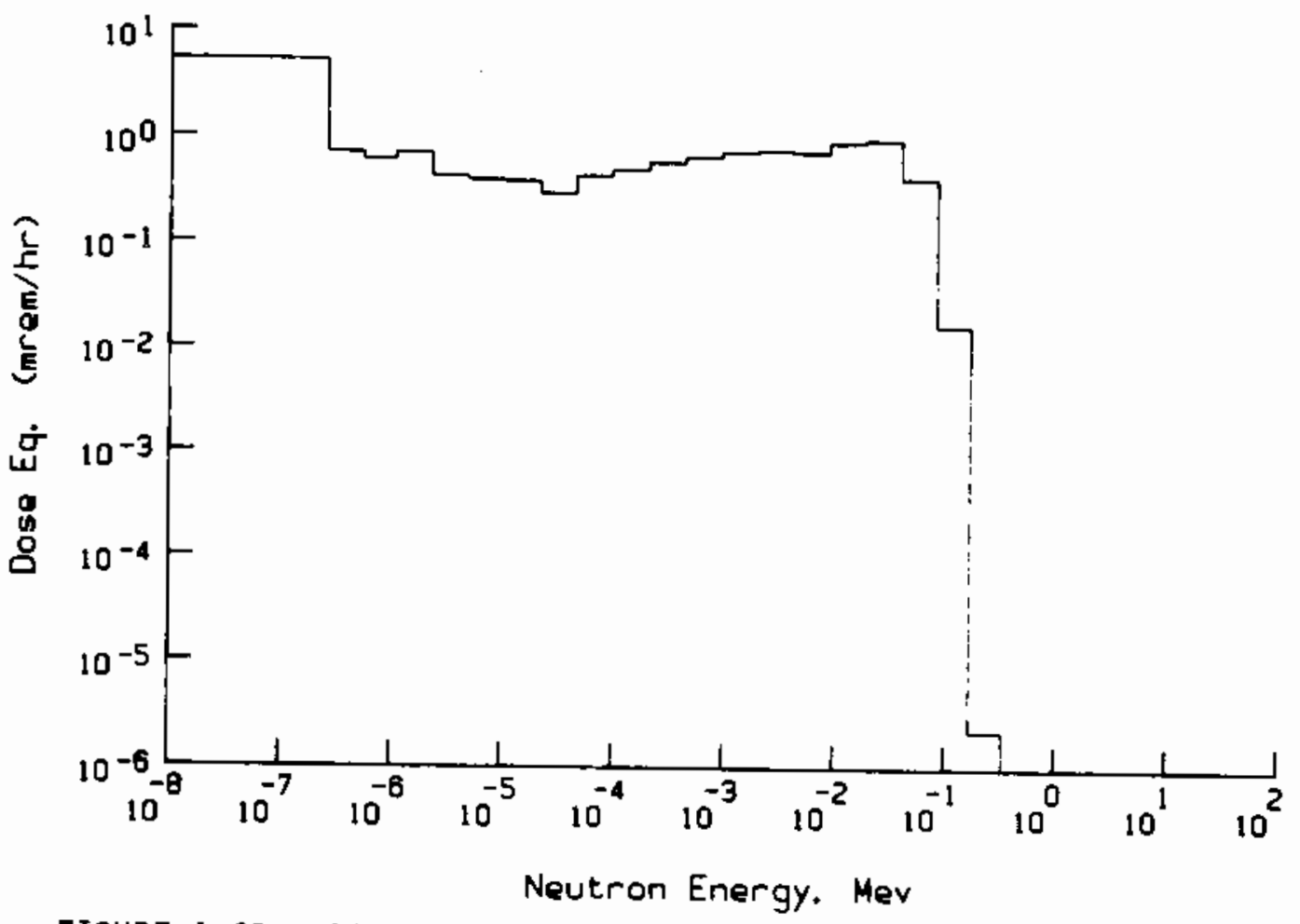

FIGURE A.60. Site 4 - Location 3 Dose Equivalent Spectrum 
TABLE A.49. Site 4 Location 4

\begin{tabular}{cccccc} 
Number of Iterations $=751$ & \multicolumn{4}{c}{ Error $=7.7 \%$} \\
Detector Responses & (Measured and Calculated) & \\
Cd-Cover & $3-$ inch & $5-$ inch & $8-$ inch & $10-$ inch & $12-$ inch \\
1623.300 & 5653.000 & 4835.700 & 2035.900 & 755.400 & 288.100 \\
1618.196 & 5732.531 & 4873.192 & 1688.466 & 798.184 & 314.841
\end{tabular}

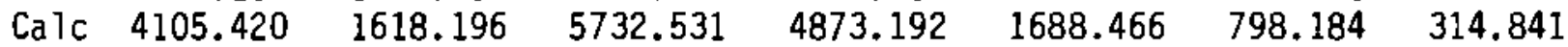

\begin{tabular}{|c|c|c|c|c|}
\hline \multirow[b]{2}{*}{$\begin{array}{l}\text { Bin } \\
\text { No. } \\
\end{array}$} & \multirow[b]{2}{*}{$\begin{array}{l}\text { Energy } \\
(\mathrm{MeV})\end{array}$} & \multirow[b]{2}{*}{$\begin{array}{c}\text { Flux } \\
\left(n / \mathrm{cm}^{2}-s\right) \\
\end{array}$} & \multicolumn{2}{|c|}{ Differential } \\
\hline & & & $\begin{array}{l}\text { Dose } \\
(\mathrm{rad} / \mathrm{hr})\end{array}$ & $\begin{array}{l}\text { Dose Equív } \\
\text { (rem/hr) }\end{array}$ \\
\hline $\begin{array}{l}1 \\
2 \\
3 \\
4 \\
5 \\
6 \\
7 \\
8 \\
9 \\
10 \\
11 \\
12 \\
13 \\
14 \\
15 \\
16 \\
17 \\
18 \\
19 \\
20 \\
21 \\
22 \\
23 \\
24 \\
25 \\
26 \\
\text { Total }\end{array}$ & $\begin{array}{l}2.57 \mathrm{E}-07 \\
5.48 \mathrm{E}-07 \\
1.06 \mathrm{E}-06 \\
2.25 \mathrm{E}-06 \\
4.77 \mathrm{E}-06 \\
1.01 \mathrm{E}-05 \\
2.14 \mathrm{E}-05 \\
4.52 \mathrm{E}-05 \\
9.58 \mathrm{E}-05 \\
2.03 \mathrm{E}-04 \\
4.34 \mathrm{E}-04 \\
9.13 \mathrm{E}-04 \\
1.92 \mathrm{E}-03 \\
4.07 \mathrm{E}-03 \\
8.62 \mathrm{E}-03 \\
1.82 \mathrm{E}-02 \\
3.86 \mathrm{E}-02 \\
8.18 \mathrm{E}-02 \\
1.67 \mathrm{E}-01 \\
3.37 \mathrm{E}-01 \\
6.79 \mathrm{E}-01 \\
1.39 \mathrm{E}-01 \\
2.78 \mathrm{E}+00 \\
5.54 \mathrm{E}+00 \\
1.12 \mathrm{E}+01 \\
2.04 \mathrm{E}+01\end{array}$ & $\begin{array}{l}1.30 \mathrm{E}+03 \\
2.94 \mathrm{E}+02 \\
2.10 \mathrm{E}+02 \\
1.72 \mathrm{E}+02 \\
1.20 \mathrm{E}+02 \\
1.02 \mathrm{E}+02 \\
8.99 \mathrm{E}+01 \\
8.38 \mathrm{E}+01 \\
8.81 \mathrm{E}+01 \\
9.89 \mathrm{E}+01 \\
1.20 \mathrm{E}+02 \\
1.50 \mathrm{E}+02 \\
1.92 \mathrm{E}+02 \\
2.50 \mathrm{E}+02 \\
3.25 \mathrm{E}+02 \\
4.08 \mathrm{E}+02 \\
4.78 \mathrm{E}+02 \\
4.25 \mathrm{E}+02 \\
1.56 \mathrm{E}+02 \\
4.27 \mathrm{E}+00 \\
1.31 \mathrm{E}-03 \\
1.25 \mathrm{E}-08 \\
1.17 \mathrm{E}-12 \\
1.63 \mathrm{E}-16 \\
2.67 \mathrm{E}-19 \\
2.53 \mathrm{E}-24 \\
5.07 \mathrm{E}+03\end{array}$ & $\begin{array}{l}2.46 \mathrm{E}-03 \\
6.45 \mathrm{E}-04 \\
4.66 \mathrm{E}-04 \\
3.79 \mathrm{E}-04 \\
2.62 \mathrm{E}-04 \\
2.20 \mathrm{E}-04 \\
1.93 \mathrm{E}-04 \\
1.79 \mathrm{E}-04 \\
1.87 \mathrm{E}-04 \\
2.03 \mathrm{E}-04 \\
2.35 \mathrm{E}-04 \\
2.83 \mathrm{E}-04 \\
3.56 \mathrm{E}-04 \\
4.57 \mathrm{E}-04 \\
5.89 \mathrm{E}-04 \\
8.27 \mathrm{E}-04 \\
1.14 \mathrm{E}-03 \\
1.20 \mathrm{E}-03 \\
5.81 \mathrm{E}-04 \\
2.24 \mathrm{E}-05 \\
1.06 \mathrm{E}-08 \\
1.53 \mathrm{E}-13 \\
1.77 \mathrm{E}-17 \\
3.40 \mathrm{E}-21 \\
6.38 \mathrm{E}-24 \\
8.29 \mathrm{E}-29 \\
1.09 \mathrm{E}-02\end{array}$ & $\begin{array}{l}5.26 \mathrm{E}-03 \\
1.35 \mathrm{E}-03 \\
9.78 \mathrm{E}-04 \\
8.04 \mathrm{E}-04 \\
5.60 \mathrm{E}-04 \\
4.75 \mathrm{E}-04 \\
4.11 \mathrm{E}-04 \\
3.73 \mathrm{E}-04 \\
3.82 \mathrm{E}-04 \\
4.12 \mathrm{E}-04 \\
4.76 \mathrm{E}-04 \\
5.72 \mathrm{E}-04 \\
7.17 \mathrm{E}-04 \\
9.18 \mathrm{E}-04 \\
1.19 \mathrm{E}-04 \\
2.28 \mathrm{E}-03 \\
4.87 \mathrm{E}-03 \\
7.89 \mathrm{E}-03 \\
4.94 \mathrm{E}-03 \\
2.25 \mathrm{E}-04 \\
1.15 \mathrm{E}-07 \\
1.51 \mathrm{E}-12 \\
1.45 \mathrm{E}-16 \\
2.38 \mathrm{E}-29 \\
4.40 \mathrm{E}-23 \\
5.74 \mathrm{E}-28 \\
3.51 \mathrm{E}-02\end{array}$ \\
\hline \multicolumn{2}{|c|}{$\begin{array}{l}\text { Total Flux } \\
\text { Dose Rate } \\
\text { Dose Equivalent Rate } \\
\text { Quality Factor } \\
\text { Average Energy }\end{array}$} & \multicolumn{3}{|c|}{$\begin{array}{l}=5.067 \mathrm{E}+03 \mathrm{n} / \mathrm{cm}^{2}-\mathrm{sec} \\
=1.089 \mathrm{E}-03 \mathrm{rad} / \mathrm{hr} \\
=3.508 \mathrm{E}-02 \mathrm{rem} / \mathrm{hr} \\
=3.220 \mathrm{rem} / \mathrm{rad} \\
=0.018 \mathrm{MeV}\end{array}$} \\
\hline
\end{tabular}




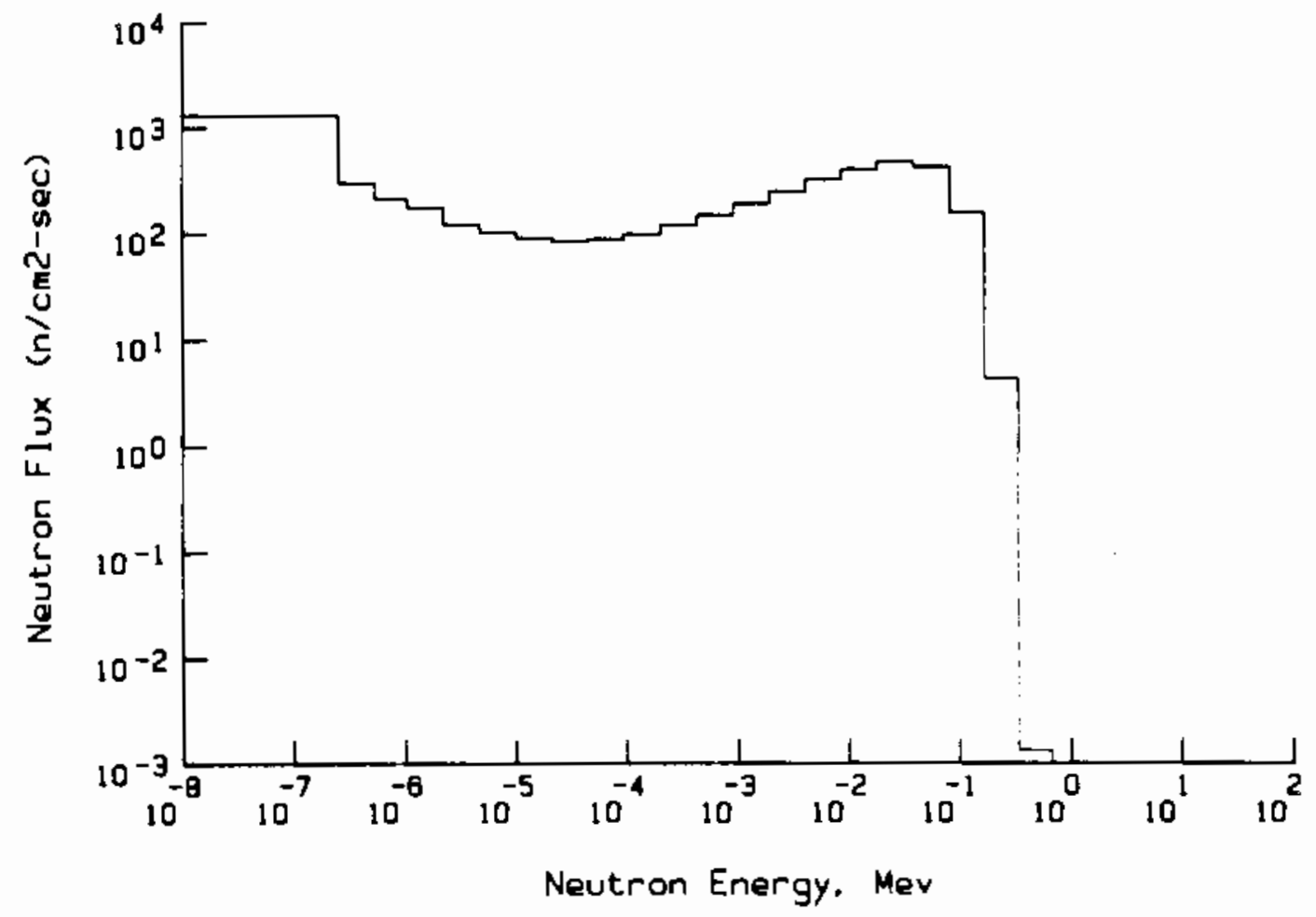

FIGURE A.61. Site 4 - Location 4 Neutron Flux Spectrum

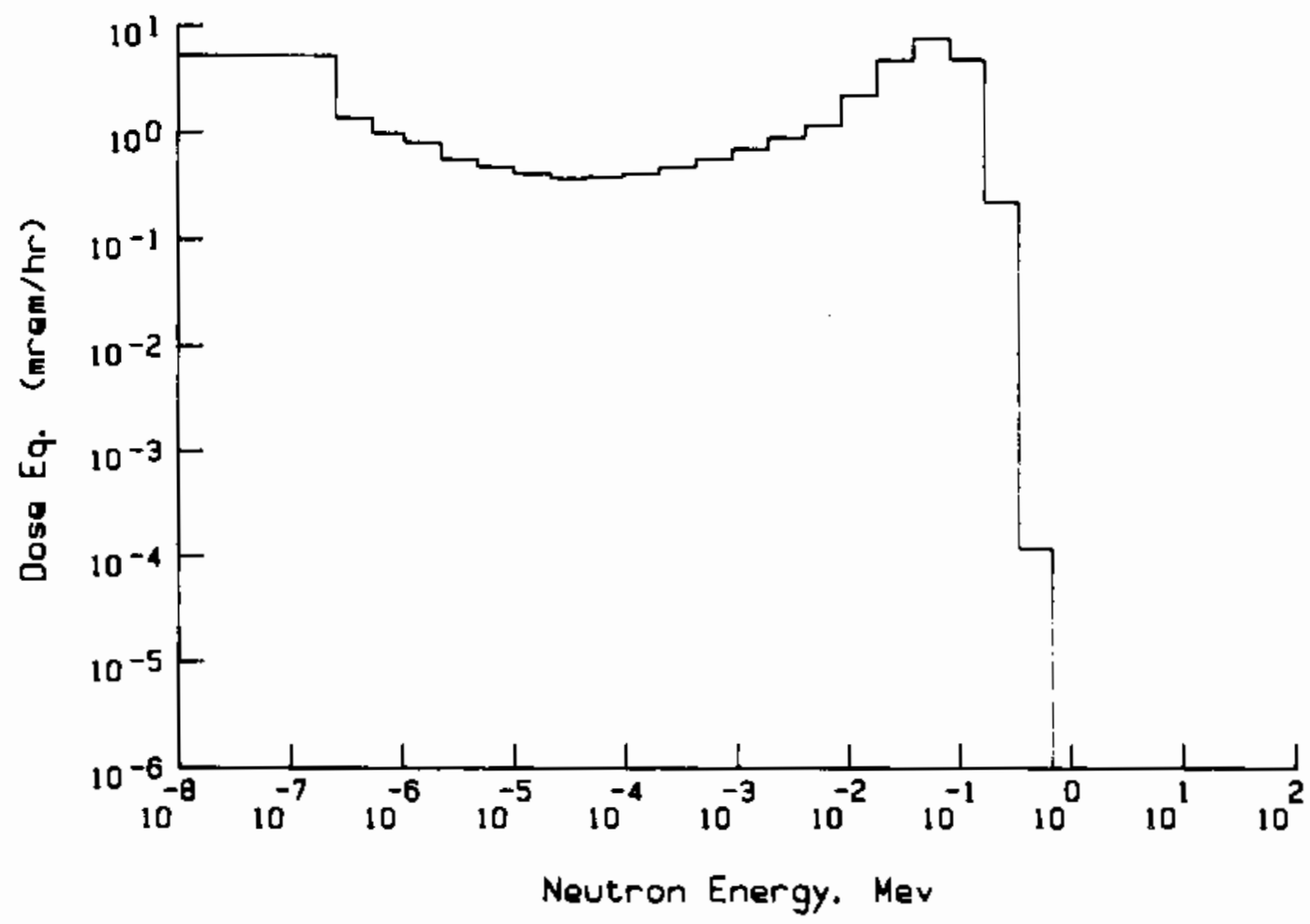

FIGURE A.62. Site 4 - Location 4 Dose Equivalent Spectrum 
TABLE A.50. Site 4 Location 5

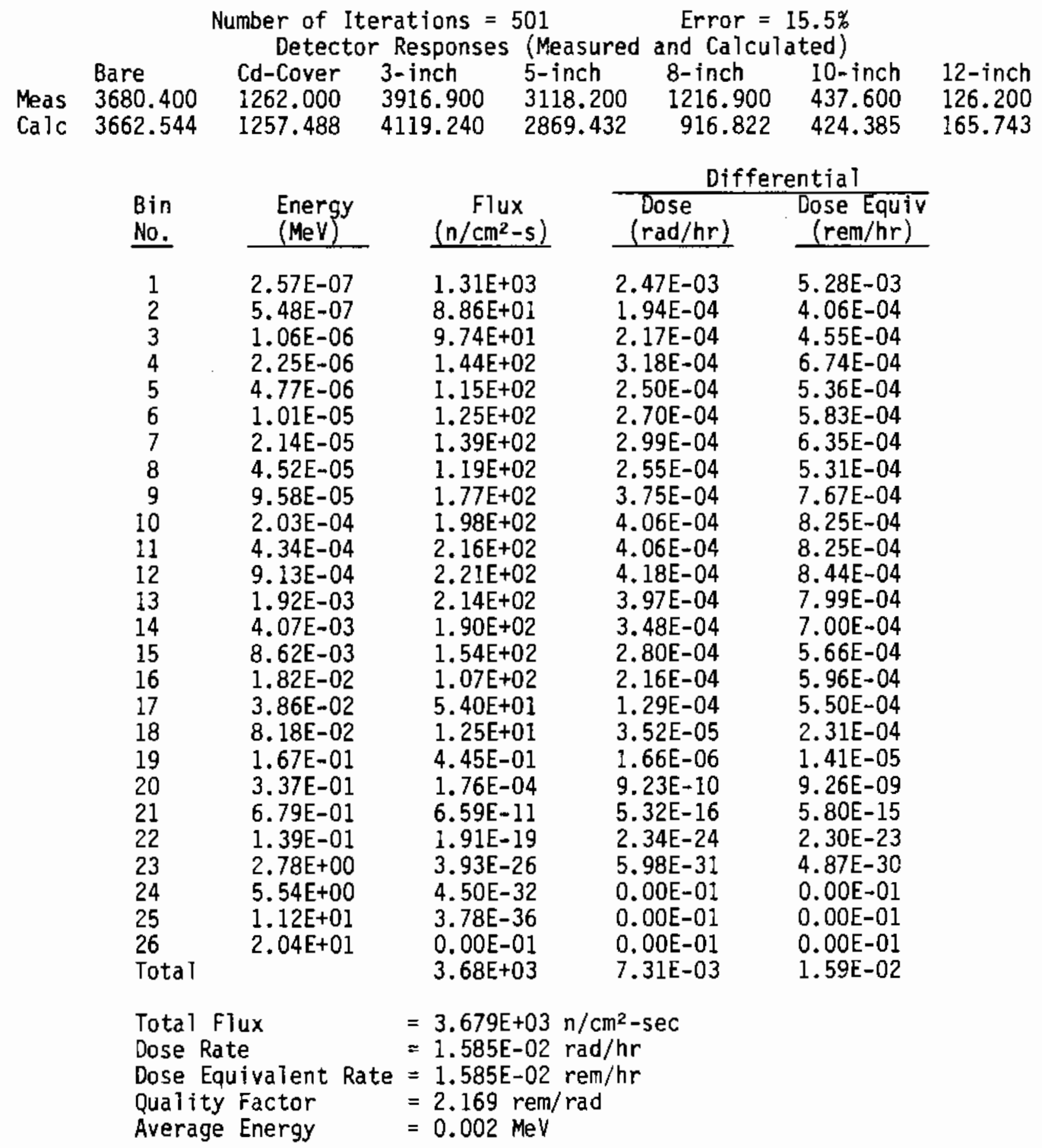




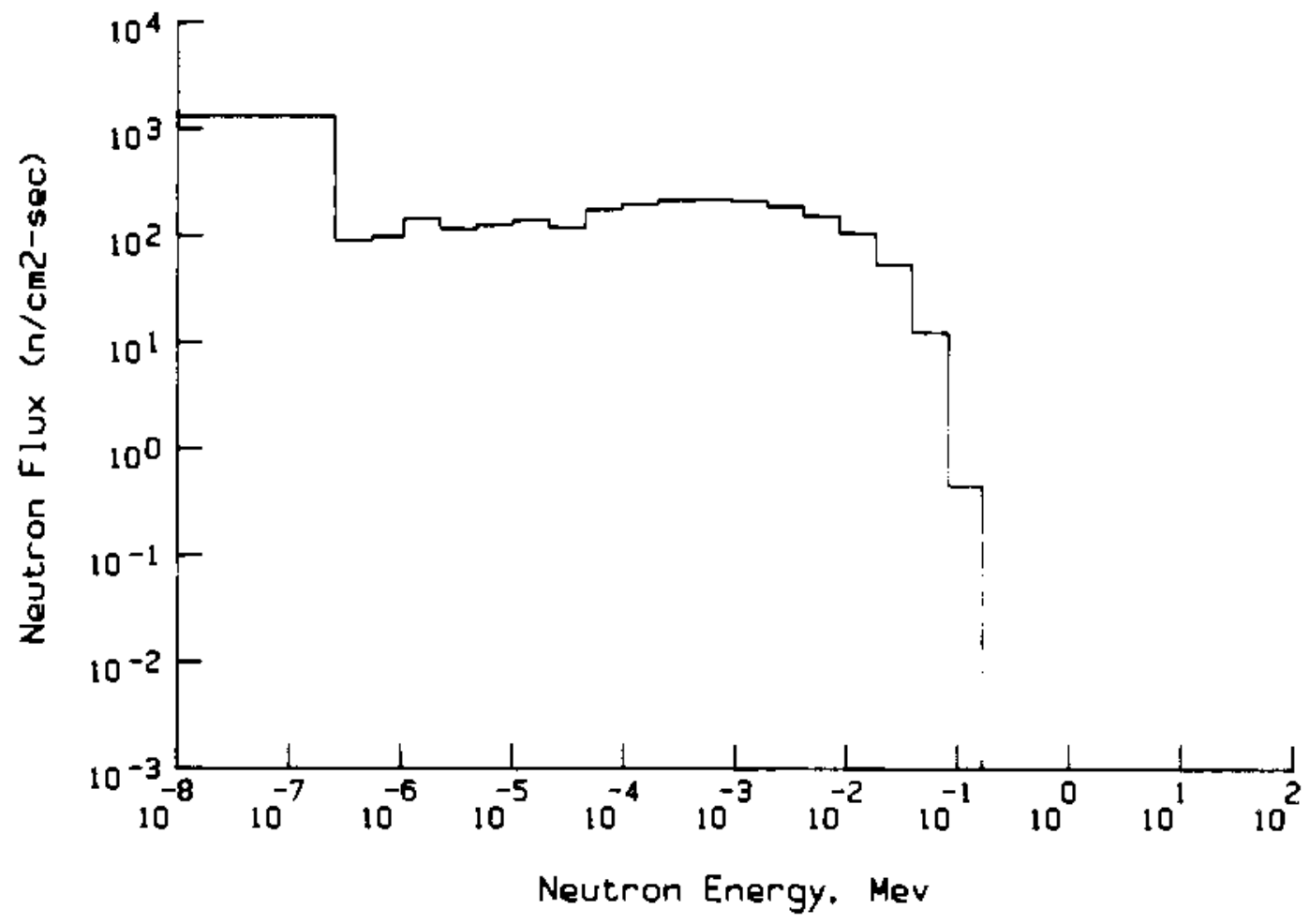

FIGURE A.63. Site 4 - Location 5 Neutron Fiux Spectrum

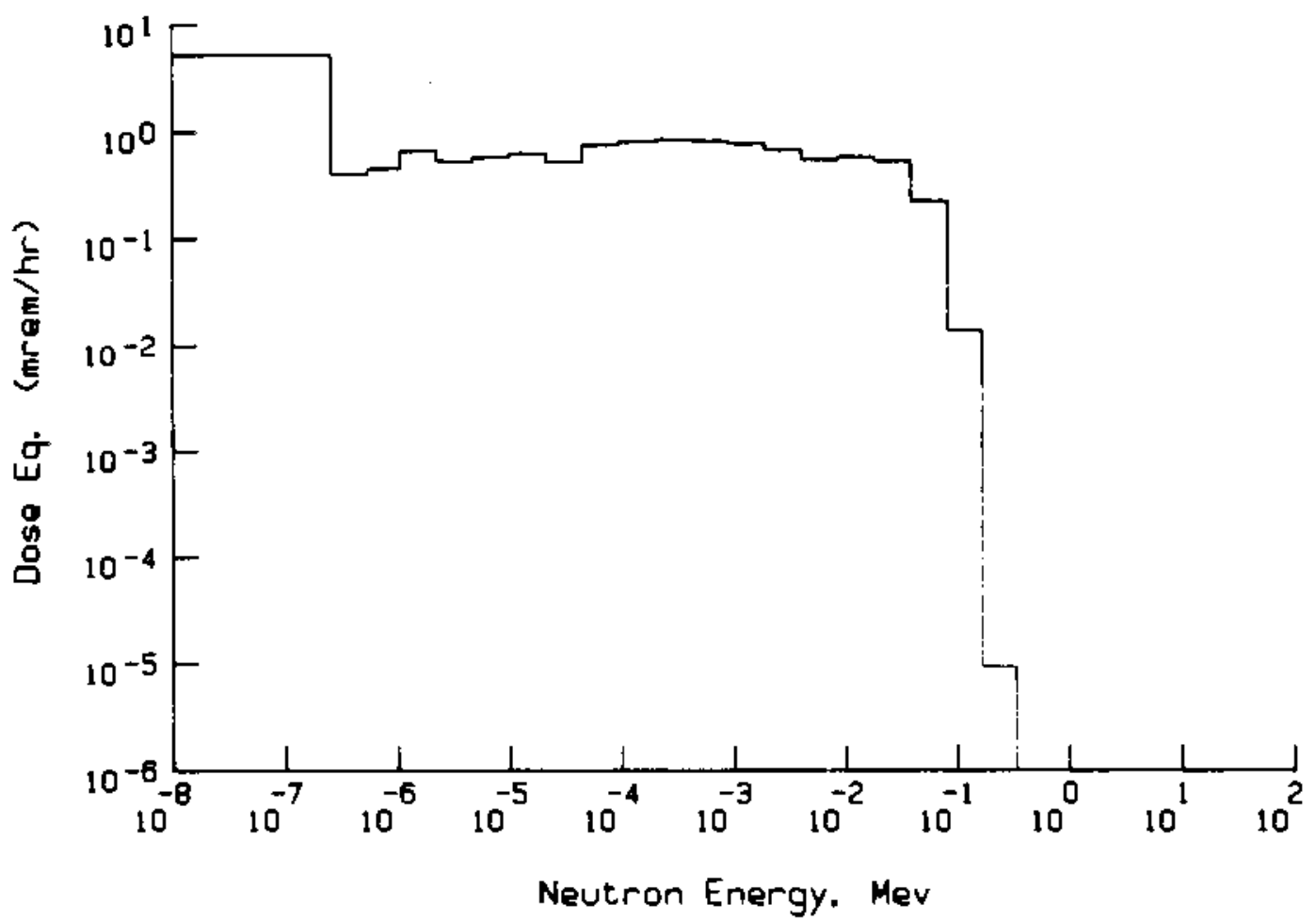

FIGURE A.64. Site 4 - Location 5 Dose Equivalent Spectrum 


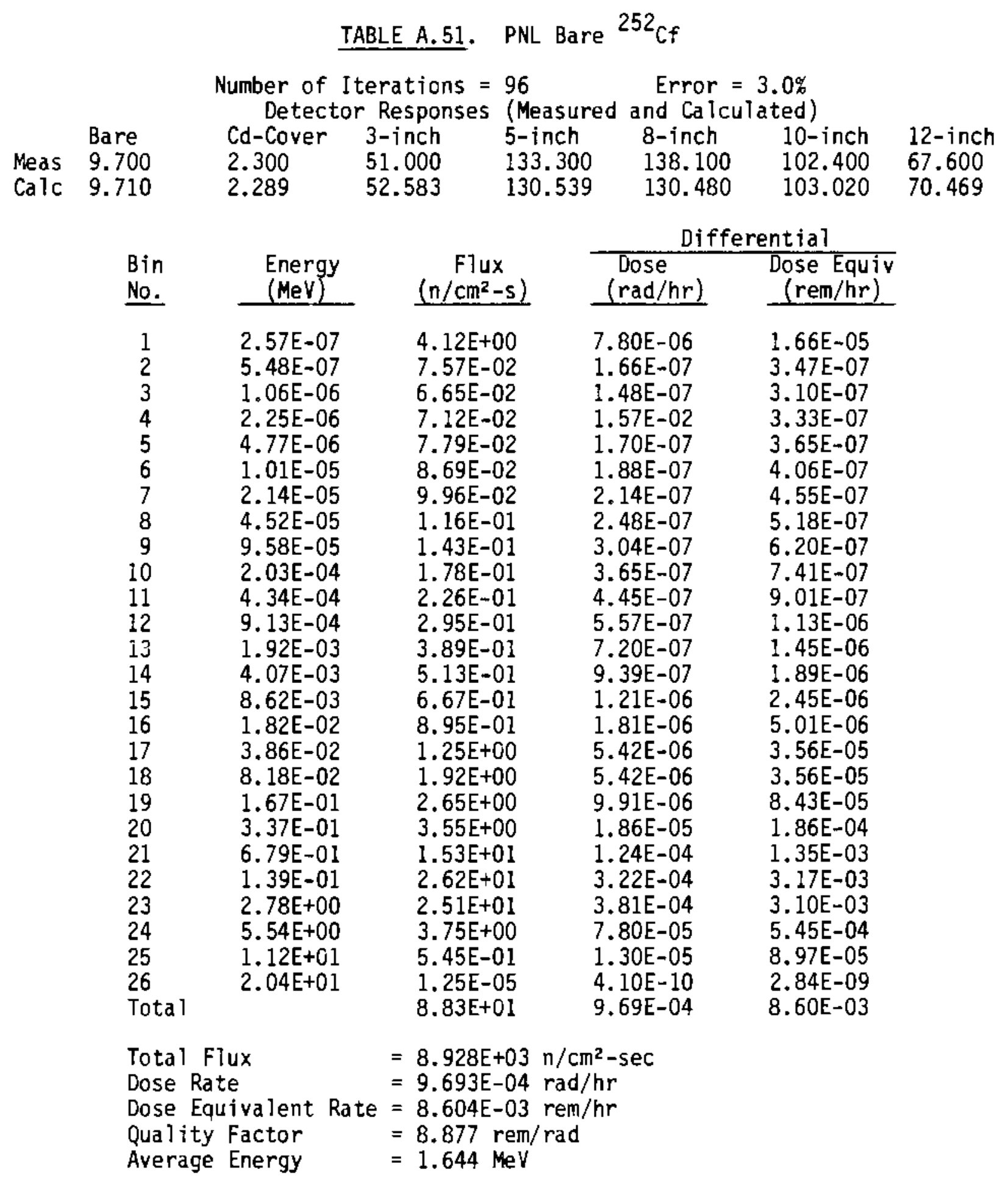



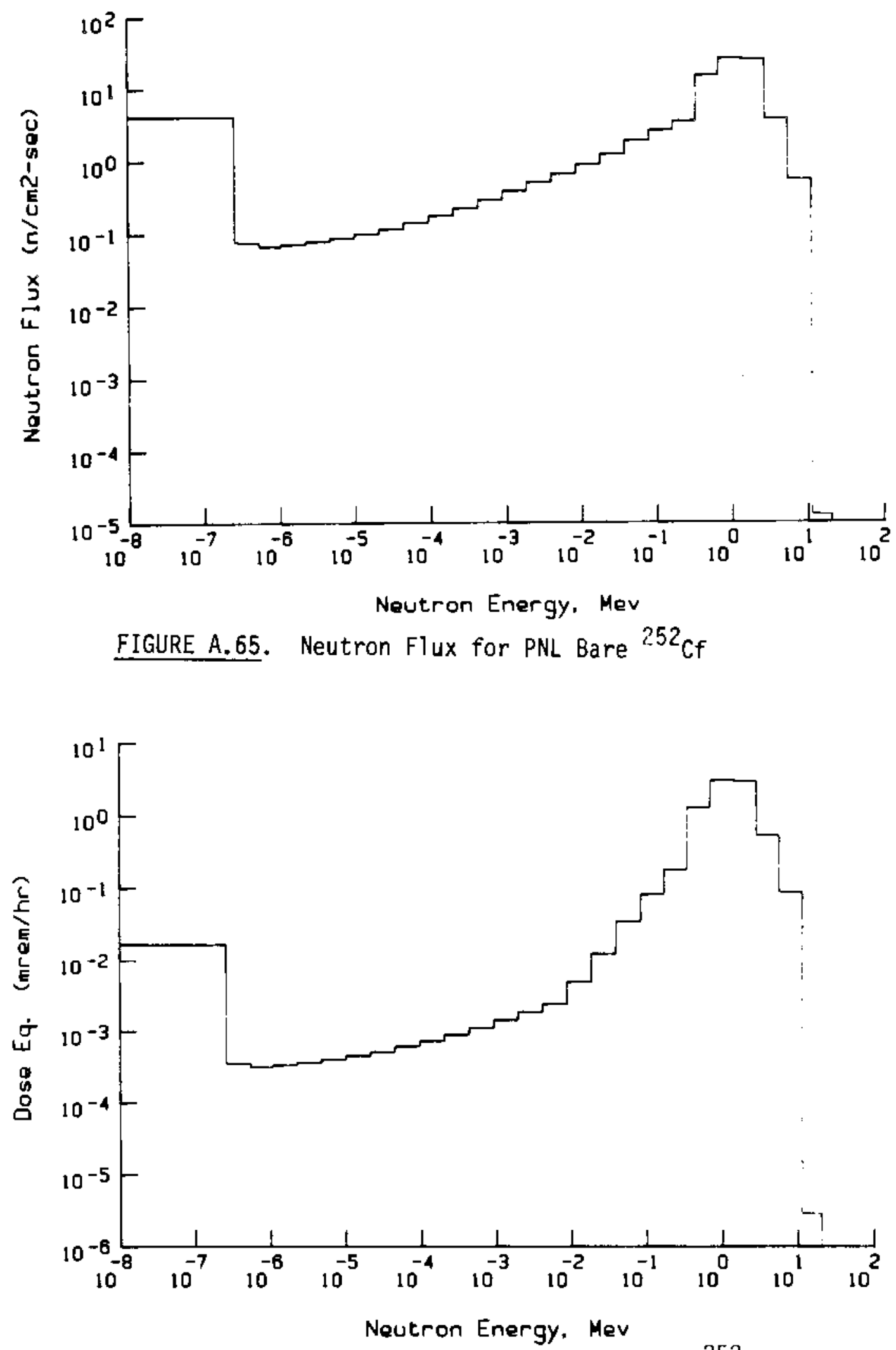

FIGURE A.66. Neutron Dose Equivalent for PNL Bare ${ }^{252} \mathrm{Cf}$ 


\section{$\underline{\text { DISTRIBUTION }}$}

No. of

Copies

OFFSITE

2 DOE Technical Information Service

10 M. A. Federline

Occupational Radiation Protection Branch

Office of Nuclear Regulatory Research

1130SS, Willste Building

U.S. Nuclear Regulatory Commission Washington, DC 20555

2 NRC Division of Technical Information and Document Control

Washington, D.C. 20555
No. of

Copies

ONSITE

35 Pacific Northwest Laboratory

L. W. Brackenbush

F. M. Cummings (10)

G. W. R. Endres

R. T. Hadley

D. E. Hadlock (5)

D. L. Haggard

G. R. Hoenes

J. C. McDonald

J. L. Pappin

P. L. Roberson

R. I. Scherpelz

K. L. Soldat

J. E. Tanner (2)

P. L. Tomeraasen

Technical Information (5)

Publishing Coordination (2) 


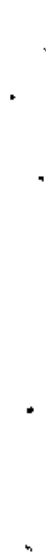

n 